\title{
A DECLARAÇÃO DAS NAÇÕES UNIDAS SOBRE A EDUCAÇÃO E FORMAÇÃO EM DIREITOS HUMANOS: RETÓRICA E PERSPECTIVAS DE EFETIVAÇÃO.
}

MESTRANDO: FÁBIO RIBEIRO HUMPHREYS GAMA

Dissertação de Mestrado encaminhada à Comissão de Pós Graduação, desenvolvida sob orientação da Professora Dra. Maria Victória de Mesquita Benevides, na área de concentração de direitos humanos da Faculdade de Direito da Universidade de São Paulo.

Faculdade de Direito

São Paulo 


\section{DEDICATÓRIA}

para Antônia Josefa, in memoriam

Tia Antônia trabalhou durante décadas limpando os chãos por onde caminhavam Autoridades, Doutores, Comendadores, Diplomatas...

Meses após sua aposentadoria - conquistada através de trabalho duro, subvalorizado e salario pífio - quando aproveitaria a vida - como costumava prenunciar - perdeu-a por desígnios do destino.

Sua doçura de menina cuja infância foi roubada sempre me acompanhará na luta para mudar a realidade das desigualdades.

Se nascemos, crescemos e morremos todos é porque somos todos iguais.

Se algo há além disto, que esteja aproveitando em paz. 


\section{AGRADECIMENTOS}

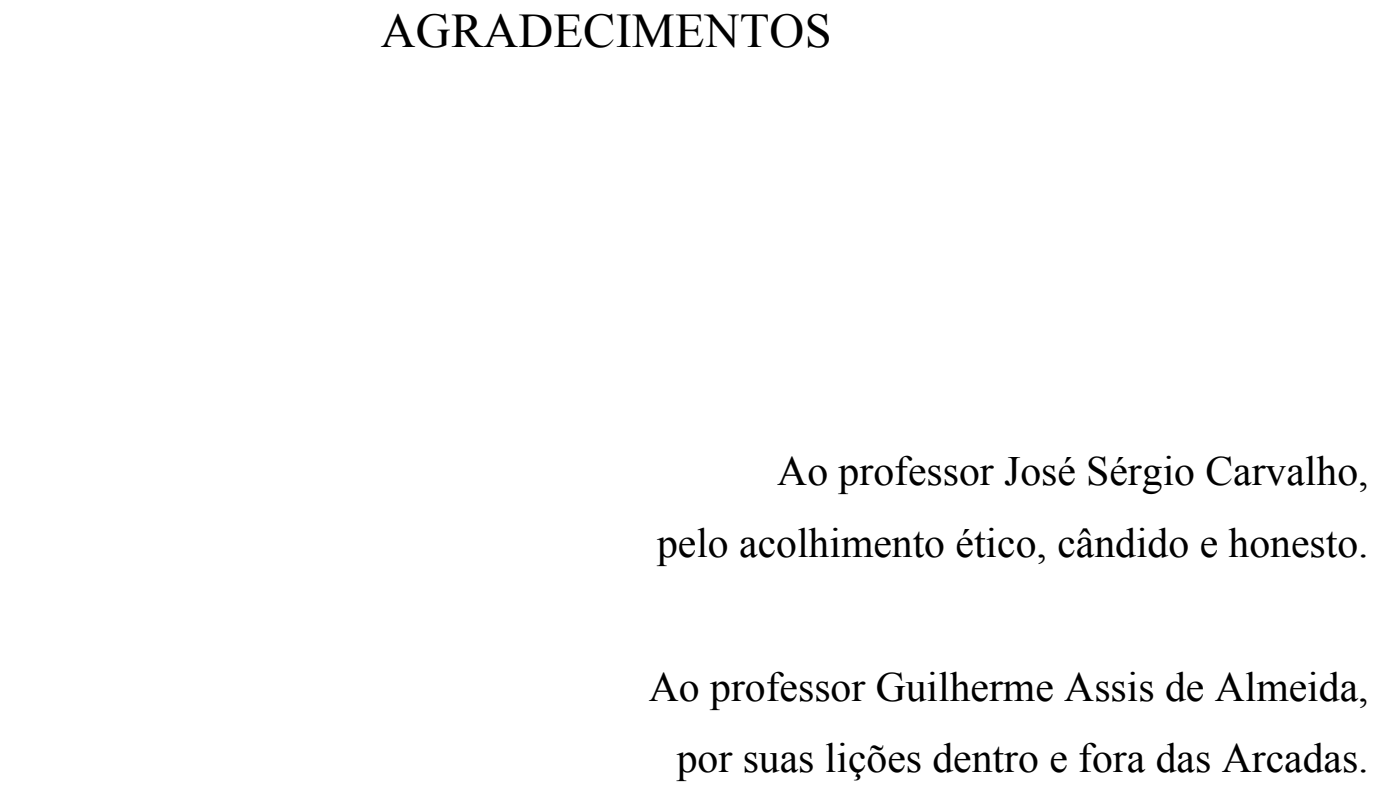

A todos os amigos e companheiros brasileiros, bolivianos, italianos e malasianos, pelo apoio de cada um à sua maneira

À minha mãe, especialmente pelo modelo de ética e honestidade

Ao meu pai, por ensinar que os desafios mais inacreditáveis podem ser superados

Imensamente

À Maria Victoria Benevides

pela transmissão de conhecimentos valiosos e exemplo de luta mas sobretudo pela paciência, tolerância, compreensão e apoio que permitiram ser possível concluir este trabalho. 


\section{EPÍGRAFE}

“ - Muito bem - disse eu a eles. - Eu sei. Vocês não sabem. Mas por que eu sei e vocês não sabem?

Aceitando o seu discurso, preparei o terreno para minha intervenção. A vivacidade brilhava em todos. De repente a curiosidade se acendeu. A resposta não tardou.

- O senhor sabe porque é doutor. Nós, não.

- Exato, eu sou doutor. Vocês não. Mas, por que eu sou doutor e vocês não?

- Porque foi â escola, tem leitura, tem estudo e nós, não.

- Porque fui à escola?

- Porque seu pai pôde mandar o senhor à escola. O nosso, não.

- E porque é que os pais de vocês não puderam mandar vocês à escola?

- Porque eram camponeses como nós.

- E o que é ser camponês?

- É não ter educação, posses, trabalhar de sol a sol sem direitos, sem esperança de um dia melhor.

- E porque ao camponês falta tudo isso?

- Porque Deus quer.

- E quem é Deus?

- É o Pai de nós todos.

- E quem é pai aqui nesta reunião?

Quase todos de mão para cima, disseram que o eram.

Olhando o grupo todo em silêncio, me fixei num deles e lhe perguntei: - Quantos filhos você tem?

- Três.

- Você seria capaz de sacrificar dois deles, submetendo-os a sofrimentos para que o terceiro estudasse, com vida boa, no Recife? Você seria capaz de amar assim?

- Não!

- Se você - disse eu --, homem de carne e osso, não é capaz de fazer uma injustiça desta, como é possível entender que Deus o faça? Será mesmo que Deus é o fazedor dessas coisas?

Um silêncio diferente, completamente diferente do anterior, um silêncio no qual algo começava a ser partejado. Em seguida:

- Não. Não é Deus o fazedor disso tudo. É o patrão!”

(FREIRE, 1992) 


\section{RESUMO}

GAMA, F. R. H.. A declaração das nações unidas sobre a educação e formação em direitos humanos: retorica e perspectivas de efetivação. 2012. 182 f. Dissertação de Mestrado - Faculdade de Direito, Universidade de São Paulo, São Paulo, 2012.

Em dezembro de 2011, a Assembleia Geral aprovou a Resolução 66/137 adotando a Declaração das Nações das Nações Unidas sobre a Educação e Formação em Direitos Humanos em sequencia ao processo educativo em direitos humanos - iniciado em 1948 com a Declaração dos Direitos Humanos - que vem em evolução constante, principalmente a partir da década de noventa. A Declaração é a reafirmação da comunidade internacional da necessidade de uma mudança de paradigma e valores que orientem a vida cotidiana dos indivíduos em todo o mundo e que é responsável pelo estado atual dos direitos humanos. Com a adoção deste novo documento internacional, começa o processo de difusão e disseminação do seu conteúdo visando a efetivação do direito humano à educação em direitos humanos - agora indubitavelmente positivado - que, sem embargo, deverá superar diversos obstáculos estruturais para a aceitação dos princípios contidos na Declaração Universal dos Direitos Humanos, vale dizer, os valores e tradições nas sociedades baseadas no patriarcalismo e no capitalismo neoliberal.

Palavras-chave: Declaração das Nações Unidas sobre a Educação e Formação em Direitos Humanos - Direitos Humanos - Educação em Direitos Humanos - Empoderamento Historia da Educação em Direitos Humanos - Direito Internacional dos Direitos Humanos - Educação - Comitê Consultivo da Conselho de Direitos humanos - Plataforma sobre a Educação em Direitos Humanos. 


\begin{abstract}
GAMA, F. R. H.. A declaração das nações unidas sobre a educação e formação em direitos humanos: retorica e perspectivas de efetivação. 2012. 182 f. Dissertação de Mestrado - Faculdade de Direito, Universidade de São Paulo, São Paulo, 2012.

In December, 2011, the UN General Assembly approved the Resolution 66/137 adopting the United Nations Declaration on Human Rights Education and Training following the human rights education movement started in 1948 by the Universal Declaration of Human Rights in an on-going evolution mainly as of the 90 's. The Declaration is the ratification by the international community of the need of changing paradigm and values which orient the life of individuals in daily basis worldwide and that is responsible for the current state of the human rights. With the adoption of this new international document the process of diffusion and dissemination of its content started aiming at the effectiveness of the right to human rights education. Yet, the Declaration must overcome many structural obstacles for the acceptance of its principles, in especial, the values and traditions of the societies based on the patriarchy and the neoliberal capitalism.
\end{abstract}

Keywords: United Nations Declaration on Human Rights Education and Training - human rights - human rights education - history of human rights education - international law of human rights - education - advisory committee - human rights council - Platform on Human Right Education. 


\section{TABELA DE ABREVIAÇÕES:}

A.C. - Antes de Cristo

ACNUDH - Alto Comissariado das Nações Unidas para os Direitos Humanos

ACNUR - Alto Comissariado das Nações Unidas para Refugiados

CAME - Council of Allied Ministers of Education

CICV - Comité Internacional da Cruz Vermelha.

D.C. - Depois de Cristo.

DEFDH - Declaração das Nações Unidas sobre Educação e Formação em Direitos Humanos.

DIDH - Direito Internacional dos Direitos Humanos

DPI - United Nations Department of Public Information

EDH - Educação em direitos humanos

EUA - Estados Unidos da América

FAO - Food and Agriculture Programme or Organization

FMI - Fundo Monetário Internacional

HREA - Human Rights Education Associates

HIV - Human Immunodeficiency Virus

INDH - Institutos Nacionais de Direitos Humanos

METU - Methodology, Education and Training Unit

OIT - Organização Internacional do Trabalho

OMS - Organização Mundial da Saúde

ONG - Organização não-governamental

ONU - Organização das Nações Unidas

OSCE - Organization for Security and Cooperation in Europe

OTAN - Organização do Tratado do Atlântico Norte

SIDA - Síndrome da Imunodeficiência Adquirida.

UNHCR - United Nations High Commission for Refugees

UN - United Nations

UNESCO - United Nations Educational Scientific and Cultural Organization.

UNFPA - United Nations Populations Fund

UNICEF - United Nations Children Fund

UNICRI - United Nations Interregional Crime and Justice Research Institute

UNODA - United Nations Office for Disarmament Affairs

UNRWA - United Nations Relief and Works Agency for Palestine Refugees.

URSS - União das Repúblicas Socialistas Soviéticas

WFP - World Food Programme

WHO - World Health Organization 


\section{SUMÁRIO}

Apresentação..................................................................................................................01

Introdução....................................................................................................................................03

1. Os Direitos Humanos: uma construção histórica.................................................10

1.1. Breve histórico do direito internacional dos direitos humanos.............................. 10

1.2. A Organização das Nações Unidas: o novo pacto global.......................................28

1.3. As normativas internacionais dos Direitos Humanos...............................................37

1.3.1. A Declaração Universal dos Direitos Humanos.............................................39

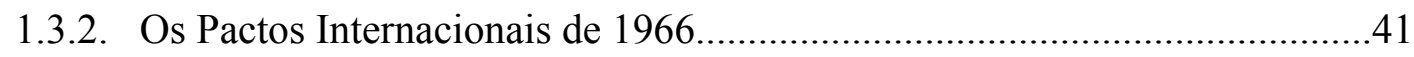

1.3.3. As conferências de direitos humanos: Teerã e Viena...................................44

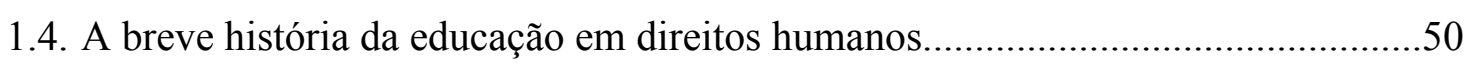

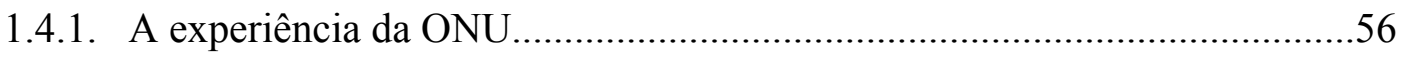

1.4.2. A Declaração de Jomtien de 1990...............................................................61

1.4.3. A Década de Educação em Direitos Humanos (1995-2004)........................62

1.4.4. O Programa Mundial de Educação em Direitos Humanos............................66

2. Do projeto de declaração das nações unidas sobre a educação e formação em

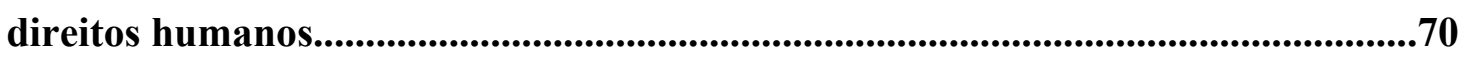

2.1. O Conselho de Direitos Humanos e seu comitê consultivo....................................70

2.2. Razões da declaração e os procedimentos iniciais................................................76

2.3. O processo coletivo-interativo da elaboração do anteprojeto.....,,...........................80

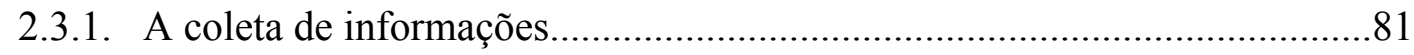

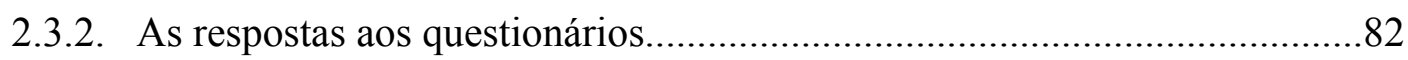

2.3.3. O seminário de Marrakesh................................................................... 90

2.4. O anteprojeto da Declaração e os comentários....................................................91

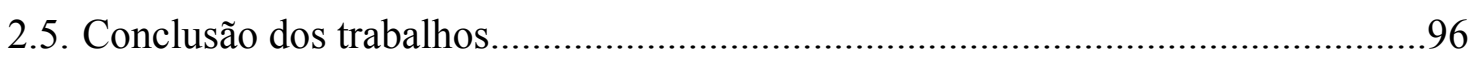

3. A Declaração das Nações Unidas sobre a Educação e Formação em Direitos Humanos..................................................................................................................................98

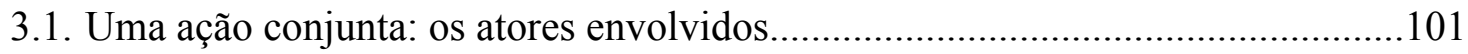

3.1.1. Responsabilidade dos Estados..........................................................101 
3.1.2. Outros atores envolvidos

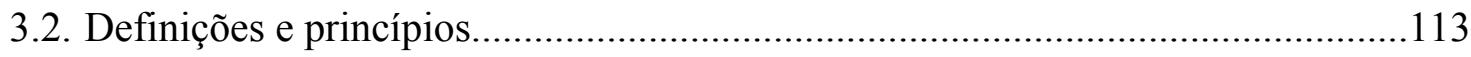

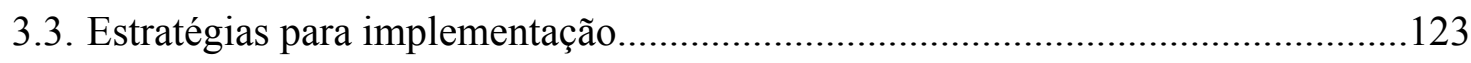

4. Perspectivas de efetivação: o mundo como não é hoje.........................................129

4.1. O principio da igualdade e as desigualdades.....................................................131

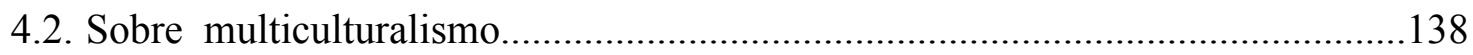

4.3. As construções sociais da realidade e a anticultura de direitos humanos..............147

Considerações finais.................................................................................................159

Referências bibliográficas.....................................................................................163

Anexo I - Quadro cronológico sobre a educação em direitos

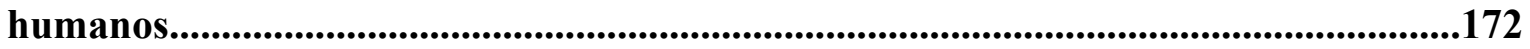

Anexo II - Declaración de las Naciones Unidas sobre la Educación e Formación en Materia de los Derechos Humanos................................................................................176 


\section{APRESENTAÇÃO}

Trata-se de dissertação desenvolvida no Programa de Mestrado em Direitos Humanos que abrange importantes aspectos do Direito Internacional, com especial ênfase sobre o processo institucional, político e pedagógico em torno da Declaração das Nações Unidas sobre a Educação e Formação em Direitos Humanos, adotada em 2011.

Por entrelaçar temas tão latos - o Direito Internacional dos Direitos Humanos e a educação -, este trabalho limitará sua análise ao processo de elaboração da referida Declaração, o que inclui as razões que levaram a ONU a decidir pela adoção de um documento especifico sobre esta matéria; colaboração dos Estados-partes, das organizações internacionais e da sociedade civil para a conclusão do texto final sem, contudo, deixar de analisar, mesmo que sucintamente, o processo histórico que resultou no cenário atual da sociedade internacional, a saber: o surgimento do Direito Internacional; a criação da ONU; a evolução dos direitos humanos e o desenvolvimento da educação sob esta nova ordem internacional, levantando, ao final, hipóteses sobre os maiores obstáculos para a efetivação do direito à educação em direitos humanos.

Devido a escolha do tema, esta dissertação não se propõe a analisar nenhum dos inúmeros elementos adjacentes à educação em direitos humanos o que tem sido objeto de várias pesquisas e debates, inclusive no nível estatal, no Brasil e no mundo. Não obstante, a questão da EDH estará presente no texto, por ser conteúdo desta nova Declaração,

Desse modo, a Introdução visa esclarecer, como ponto de partida, a concepção contemporânea dos direitos humanos, reunindo documentos oficiais do Direito Internacional dos Direitos Humanos, assim como a abordagem Human Rights Approach to development voltada para normativas e padrões que buscam consenso.

O capitulo 1 borda os eventos históricos que desencadearam na criação da nova ordem internacional, passando a tratar, no capitulo seguinte, de todo o processo de preparação e elaboração do projeto da Declaração, investigando as suas razões, bem como analisando o processo coletivo de elaboração e adoção final.

No capitulo 3, por sua vez, será analisada a Declaração aprovada pela Assembleia Geral e seu conteúdo, identificando-se o resultado final em contraste com o processo de elaboração, assim como as mudanças pertinentes ocorridas durante o processo de elaboração. 
Finalmente, no quarto e ultimo capitulo, analisaremos alguns elementos que destacamos como os maiores obstáculos para a efetivação da Educação em Direitos Humanos, vale dizer: a contradição entre o principio da igualdade (essencial ao conceito de DH) e as desigualdades concretas; a polêmica do multiculturalismo versus universalismo e o papel das construções sociais da realidade.

A pesquisa foi baseada na analise bibliográfica, principalmente dos documentos emitidos pelo sistema das Nações Unidas sobre a educação em direitos humanos que levaram à elaboração e adoção do documento final.

Uma vez que o português não é língua oficial da ONU, a quase totalidade dos documentos analisados apresentam-se em língua estrangeira. Por este motivo, diversas citações observadas ao longo do texto estarão na língua original. No caso dos documentos oficiais da ONU, por ser o espanhol língua oficial e, devida a proximidade deste com o português, optamos, sempre que possível, por este idioma. Porém, nem sempre existe esta disponibilidade devido ao tempo em que as traduções oficiais são publicadas - não acompanhando o próprio processo de elaboração da Declaração - ou simplesmente por não haver tradução em todos os idiomas oficiais. Neste caso, priorizamos o inglês e, em ultima instancia, o francês, por entendermos ser aquele mais amplamente difundido que este.

O autor é militante dos DH e trabalha na área de formação. Está, portanto, ciente dos riscos de abuso de retórica, contra o quais se preveniu utilizando os textos oficiais e procurando, sempre que necessário, distinguir sua opinião pessoal da realidade do contexto oficial das instituições internacionais.

Nesse sentido, o que se propõe é contribuir para o avanço do conhecimento nesta área, tendo por objetivo o de compreender e debater as possibilidades de adesão à Declaração, a partir do consenso original conseguido pela ONU. 


\section{INTRODUÇÃO}

\section{A Concepção contemporânea dos direitos humanos.}

O conceito ou ideia de concepção é valioso para este trabalho. Segundo o dicionário Michaelis, concepção ${ }^{1}$ - do latim conceptione - tem, a grosso modo, dois sentidos: (i) significa o ato de conceber ou ser concebido, e neste sentido; geração, criação ou obra do espírito e (ii) significa também a faculdade de compreender as coisas, percepção, e neste sentido os significados de fantasia, imaginação, imagem de uma coisa na mente. Sobre este último sentido comentaremos ao final, focando agora no primeiro.

Pois bem, a concepção dos direitos humanos contemporânea, no sentido de criação, geração, surge com a adoção da Declaração Universal dos Direitos Humanos (DUDH) em resposta às atrocidades cometidas na Segunda Guerra mundial pelo regime nazifascista, por um lado, e a inauguração da era atômica - com o lançamento de 2 bombas de hidrogênio em Hiroshima e Nagasaki, pelos Estados Unidos da América (EUA), por outro.

A DUDH foi elaborada sob os auspícios da recém criada Organização das Nações Unidas (ONU), em 1945, em atenção ao documento que a criou, a Carta das Nações Unidas, que estabelecia toda uma nova ordem mundial pós-guerra, com o propósito de regular a relação entre os Estados e entre estes e os indivíduos. Se por um lado, a Carta das Nações Unidas, pretende regular a relação interestatal, a DUDH, mais especificamente, visa regular a relação Estados-indivíduos universalmente, inaugurando o processo de normatização internacional dos direitos humanos ao conceder ao individuo titularidade no Direito Internacional. Portanto, a DUDH, assinada em São Francisco, EUA, em 10 de dezembro de 1948, concebe os direitos humanos como os conhecemos atualmente e será o marco metodológico conceitual desta dissertação.

Além de elencar, em seus 30 artigos, o rol dos direitos considerados humanos, a DUDH traz em seu preâmbulo, os essenciais princípios dos direitos humanos, quais sejam os princípios da dignidade, igualdade, liberdade, inalienabilidade, universalidade, indivisibilidade e interdependência. Estes princípios vêm sendo reafirmados ao longo da

\footnotetext{
${ }^{1}$ Concepção con.cep.ção sf (lat conceptione) 1. Ato de conceber ou ser concebido. 2 Geração. 3 Faculdade de compreender as coisas; percepção. 4 Fantasia, imaginação. 5 Criação ou obra do espírito.6 Imagem de uma coisa na mente. $C$. de papel, Sociol: idéia que a pessoa formula da sua própria atuação e status nos grupos sociais a que pertence. C. do mundo: imagem subjetiva do mundo, concebida por um indivíduo ou grupo, de acordo com determinado ponto de vista. Dicionário UOL-Michaelis online. Disponível em http://michaelis.uol.com.br/moderno/portugues/index.php?lingua=portugues-portugues\&palavra=concepcao
} 
historia da construção das normativas internacionais de direitos humanos e são elementos necessários para a compreensão dos direitos humanos como ramo específico do Direito.

A partir da Declaração de 1948, começa a se desenvolver o Direito Internacional dos Direitos Humanos, mediante a adoção de diversos instrumentos internacionais de proteção. “A Declaração de 1948 confere lastro axiológico e unidade valorativa a este campo do Direito, com ênfase na universalidade, indivisibilidade e interdependência dos direitos humanos",

Enquanto os princípios da dignidade, liberdade e igualdade, tratam diretamente de atributos e qualidades que devem ser garantidos a todos os indivíduos pelo único motivo de serem humanos, os princípios da universalidade, indivisibilidade, interdependência e inalienabilidade são qualidades dos direitos humanos normatizados.

A universalidade determina que os direitos humanos valem para todo o ser humano no planeta $^{3}$, independente da jurisdição ou regime político ao qual ele está submetido, enquanto a inalienabilidade determina que estes direitos jamais podem ser perdidos. A universalidade dos direitos humanos é característica fundamental destes e será analisada ao longo de praticamente toda a obra.

Decorrentes da Declaração, surgem, em 1966, os Pactos Internacionais dos Direitos Civis e Políticos (PIDCP) e Econômicos, Sociais e Culturais (PIDESC), que, apesar da divisão - justificada pela natureza de aplicação imediata (civis e políticos) e de aplicação progressiva (econômicos, sociais e culturais) - concretizam o entendimento que todos os direitos humanos são indivisíveis, interdependentes, interconexos, inter-relacionáveis, em suma, os direitos humanos somente são satisfeitos se respeitados na integralidade de seu conjunto, não se podendo falar em satisfação dos direitos humanos se algum deles não for garantido. Por conseguinte, os direitos humanos são um conjunto de direitos que devem ser respeitados, protegidos ou promovidos, dependendo de sua natureza, como um ideal a ser alcançado somente se em sua totalidade.

Outra característica inegável na concepção contemporânea dos direitos humanos é a internacionalidade. Pois bem, primeiro, obviamente, por sua própria natureza - ser resultado de um tratado internacional -, segundo, pelos princípios da inalienabilidade e universalidade $^{4}$, estabelecidos pela DUDH. Ou seja, se todos os direitos humanos se

\footnotetext{
${ }^{2}$ PIOVESAN, Flavia. (Coord.) Direitos Humanos. $1^{\text {a }}$ Edição. Curitiba: Juruá, 2007. p. 18.

${ }^{3}$ Veremos a questão da imposição da universalidade mais adiante no capitulo 4.

${ }^{4} \mathrm{O}$ próprio nome da Declaração ser Universal e não Internacional.
} 
aplicam a todos os seres humanos pelo simples fato de serem humanos e, uma vez que os humanos estão espalhados no planeta e este, dividido em nações, os direitos humanos são inexoravelmente internacionais, ou melhor dizendo, universais, pois independem da vontade de nenhuma nação.

Por ser resultado de consenso internacional, o princípio da universalidade impõe que os direitos humanos estão de tal forma interligados - pela interdependência deles - e internacionalmente conectados, na medida que o aperfeiçoamento de um direito humano aqui, influencia no estândar que deverá ser seguido acolá.

Estes quatro documentos - Carta das Nações Unidas, DUDH, PIDCP e PIDESC formam a Carta Internacional dos Direitos Humanos, donde se depreendem os direitos humanos entendidos como civis, políticos - tidos como de primeira geração - e os econômicos, sociais e culturais - de segunda geração. Esta divisão dos direitos humanos em gerações é severamente criticada por parte da doutrina, por entender ser ela atentatória ao principio da indivisibilidade e interdependência dos direitos humanos.

É seguro afirmar que os direitos humanos são o resultado de conquistas históricas através da luta dos povos contra a opressão dos governantes e, por esta natureza, são ainda inacabados e não terminativos, significando que eles estão em processo de metamorfose constante, sendo expandidos, aprofundados ou aperfeiçoados. Fala-se, desde algum tempo em direitos humanos de terceira geração ${ }^{5}$, que seriam os direitos coletivos (ex.: paz, meio ambiente saudável, desenvolvimento, etc.), estes, mais interconexos ainda com os outros direitos humanos originários.

Fato é que, sob a égide da ONU os direitos humanos desenvolveram-se rapidamente em um complexo sistema de promoção e proteção em geral, através do Conselho de Direitos Humanos, ou especificamente, através dos órgãos de tratados, que são os comitês responsáveis pela aplicação e implementação dos direitos defesos em tratados específicos (direitos da criança, discriminação contra a mulher, pessoas com deficiência, etc.). Não obstante, apesar da normatização, sistematização e desenvolvimento dos trabalhos em campo para a garantia dos direitos humanos, estes não gozam de situação da qual podemos nos orgulhar. Atrocidades atentatórias aos direitos humanos parecem andar em descompasso com sua sistematização internacional. Indiscutivelmente, o problema dos direitos humanos na atualidade não é a falta de normas sobre eles, mas sim a

\footnotetext{
${ }^{5}$ Se entendermos os direitos civis e políticos como de primeira geração e os direitos econômicos, sociais e culturais de terceira.
} 
implementação delas. Sobre isso, comentou Bobbio:

Há três anos, no simpósio promovido pelo Institut International de Philosophie sobre o Fundamento dos Direitos do Homem tive oportunidade de dizer, num tom um pouco peremptório, no final de minha comunicação, que o problema grave de nosso tempo, com relação aos direitos do homem, não era mais o de fundamentá-los, e sim o de protegê-los. Desde então, não tive razões para mudar de idéia. Mais que isso: essa frase que, dirigida a um público de filósofos, podia ter uma intenção polêmica - pôde servir, quando me ocorreu repeti-la no simpósio predominantemente jurídico promovido pelo Comitê Consultivo Italiano para os Direitos do Homem, como introdução, por assim dizer, quase obrigatória. Com efeito, o problema que temos diante de nós não é filosófico, mas jurídico e, num sentido mais amplo, político. Não se trata de saber quais e quantos são esses direitos, qual é sua natureza e seu fundamento, se são direitos naturais ou históricos, absolutos ou relativos, mas sim qual é o modo mais seguro para garanti-los, para impedir que, apesar das solenes declarações, eles sejam continuamente violados. ${ }^{6}$

Importante salientar que o discurso acima data de 1967! Desde então, podemos dizer que a situação dos direitos humanos no mundo não melhorou, e, sob certos aspectos, até mesmo piorou.

Desta forma, e, restando claro que os direitos humanos são expansíveis, decorrentes de conquistas históricas, o foco principal da luta por eles, além de agregar novos direitos reconhecidos, reside na implementação e efetivação dos direitos já reconhecidos, direta ou indiretamente, por uma vasta lista de documentos internacionais de direitos humanos.

A Carta da ONU e a DUDH inauguraram os direitos humanos como nova matéria do Direito Internacional Público, ou Direito das Gentes. O Direito Internacional dos Direitos Humanos (DIDH) regula a maneira que os Estados tratam os indivíduos sob sua jurisdição.

O moderno regime de tratados multilaterais regulando direitos humanos específicos vem se desenvolvendo ao regular diversos temas de direitos humanos, como o genocídio (1951), a discriminação racial (1965), os direitos civis e políticos e econômicos sociais e culturais (1966), a discriminação contra a mulher (1979), a tortura (1984) os direitos da criança (1989), os trabalhadores migrantes (1990), as pessoas com deficiência (2006) e o

\footnotetext{
${ }^{6}$ BOBBIO, Norberto. A era dos direitos. Trad. Carlos Nelson Coutinho. Rio de Janeiro: Elsevier, 2004. p. 25. Continuando o discurso,: "De resto, quando a Assembleia Geral da ONU, em sua última sessão, acolheu a proposta de que a Conferência Internacional dos Direitos do Homem, decidida na sessão do ano anterior, fosse realizada em Teerã na primavera de 1968, fazia votos de que a conferência assinalasse "um notável passo à frente na ação empreendida no sentido de encorajar e ampliar o respeito aos direitos humanos e às liberdades fundamentais"? Entende-se que a exigência do respeito" aos direitos humanos e às liberdades fundamentais nasce da convicção, partilhada universalmente, de que eles possuem fundamento: o problema do fundamento é ineludível. Mas, quando digo que o problema mais urgente que temos de enfrentar não é o problema do fundamento, mas o das garantias, quero dizer que consideramos o problema do fundamento não como inexistente, mas como - em certo sentido - resolvido, ou seja, como um problema com cuja solução já não devemos mais nos preocupar. Com efeito, pode-se dizer que o problema do fundamento dos direitos humanos teve sua solução atual na Declaração Universal dos Direitos do Homem aprovada pela AssembleiaGeral das Nações Unidas, em 10 de dezembro de 1948."
} 
desaparecimento forçoso de pessoas (2006). E este processo continua em franca expansão.

Outro entendimento da concepção dos direitos humanos que utilizaremos nesta obra, vem da definição extraída do conceito de Human Rights Approach to Development, entendimento criado no âmbito da $\mathrm{ONU}^{7}$, que, além da concepção trazida pela DUDH, pretende pautar todo o seu trabalho com foco nos direitos humanos, com o objetivo de implementá-los e efetivá-los através dos esforços para trazer "desenvolvimento" aos países mais desfavorecidos, em atenção ao próprio propósito da ONU.

Human Rights based-approach (em tradução livre do autor "abordagem baseada em direitos humanos") é um conceito baseado em diretrizes de direitos humanos necessários para o processo do desenvolvimento humano, recorrendo às normativas e estândares internacionais, e operacionalmente dirigidos a promover e proteger os direitos humanos. Ele busca analisar desigualdades que ligam na essência do desenvolvimento problemas como práticas discriminatórias e distribuições injustas de poder, por exemplo, que impendem o seu progresso. Este conceito entende que a mera caridade não é suficiente sob uma perspectiva de direitos humanos, traduzindo ações assistencialistas em reconhecimento de direitos. Sob uma abordagem baseada em direitos humanos, os planos, as políticas e os processos de desenvolvimento são ancorados em um sistema de direitos e correspondem às obrigações estabelecidas pelo Direito Internacional. Isso auxilia a promover a sustentabilidade do desenvolvimento, empoderando as próprias pessoas cujos direitos são violados - especialmente as mais marginalizadas - a participarem da formulação de políticas e identificação dos responsáveis por implementá-las.

Embora não haja receita universal para o Human Rights Based Approach, as agencias da ONU concordaram em um numero de atributos essenciais: (i) em todas as políticas e programas de desenvolvimento, o objetivo principal deve ser a realização dos direitos humanos. (ii) Human rights based-approach identifica os direitos, os seus titulares e os correspondentes responsáveis por adimplir essas obrigações para que aqueles recorram a estes para reclamá-los.

Resumidamente, o human rights based approach envolve cinco elementos: (i) Participação; (ii) Responsabilização final; (iii) Não-discriminação (iv) Empoderamento;

\footnotetext{
${ }^{7}$ Discurso de Kofi Annan, ex-Secretário Geral da ONU, em 1999:" As the Secretary-General of the United Nations I have made human rights a priority in every programme the United Nations launches and in every mission we embark on. I have done so because the promotion and defense of human rights is at the heart of every aspect of our work and every article of our Charter." Disponivel em http://portal.unesco.org/shs/en/ev.phpURL_ID\%3D7934\&URL_DO\%3DDO_TOPIC\&URL_SECTION\%3D 201.html acessado em 03.01.2012
} 
(v) Vinculação com estândares internacionais, sendo amplamente utilizado metodologicamente em programas de educação popular em direitos humanos internacionalmente e uma concepção dos direitos humanos orientada para a prática.

Já o segundo significado de concepção que mencionamos na abertura do texto compreensão, imaginação ou ideia de que se tem das coisas - também será importante por se tratar de trabalho de Direito Internacional sobre a educação em direitos humanos (EDH), e dessa maneira, tem por objeto, como os valores e princípios constantes da DUDH e expandidos historicamente são ou deverão ser absorvidos pelos indivíduos através da educação.

Concepção é a faculdade de compreender as coisas, é a imagem ou idéia que se tem na mente sobre alguma coisa. Até o momento, comentamos sobre a concepção dos direitos humanos construída internacionalmente através da diplomacia e política internacional, uma concepção política, jurídica, acadêmica e científica, não uma concepção popular.

Como aludimos, muito se fez e continua se fazendo em prol do desenvolvimento de um sistema internacional de proteção e promoção dos direitos humanos, porém é recorrente o problema da implementação ou da efetivação destes direitos. Se falhamos na implementação dos direitos humanos, falhamos na educação sobre eles porquanto é a própria educação, e a EDH, um direito humano.

Os direitos humanos carregam forte carga axiológica eivada de preconceitos que obstaculizam o entendimento do que são exatamente os direitos humanos, e, corolariamente, a implementação destes. É forçoso indagar: qual é a concepção do cidadão comum sobre os direitos humanos? Podemos dizer que o conteúdo das páginas anteriores, muito básico para expertos, é conhecimento de domínio comum?

Ainda segundo o mesmo dicionário, na sociologia, concepção de papel é a idéia que o indivíduo formula da sua própria atuação e status nos grupos sociais a que pertence. Pois, sem princípios alinhados aos direitos humanos transmitidos através da educação, como os indivíduos formulam a sua atuação?

Seguindo a mesma linha de pensamento, quais são as fantasias, os mitos, os preconceitos criados para falsear a concepção do que são os direitos humanos, que variam de modalidade de acordo com a cultura e conjunturas locais que formam a sua concepção de mundo, ou seja, a imagem subjetiva do mundo, concebida por um individuo ou grupo, de acordo com determinado ponto de vista, fantasias essas que frequentemente operam em favor da opressão e da injustiça. 
A motivação da ONU para a elaboração de uma Declaração sobre Educação e Formação em Direitos Humanos (DEFDH) é justamente mudar este cenário, imprimindo mais esforços na realização da educação em direitos humanos em nível global, buscando criar uma cultura de direitos humanos, em outras palavras, formar uma boa concepção de direitos humanos em cada individuo do planeta.

O desafio é hercúleo. 


\section{Capítulo 1}

\section{Direitos humanos: uma construção histórica}

\subsection{Breve histórico do Direito Internacional dos Direitos Humanos}

Sendo os Direitos Humanos ramo do Direito Internacional e um fenômeno histórico, não podemos deixar de analisar, mesmo que brevemente, a História do Direito Internacional e, consequentemente, do DIDH.

Eventualmente, o próprio termo Direito Internacional dos Direitos Humanos gera discordância, entendendo alguns que, "apesar de criar uma conveniente categoria de referência, é também fonte de confusão, uma vez que problemas de direitos humanos ocorrem em contextos legais específicos", ou seja, os problemas surgem no direito domestico $^{8}$. Em nosso entendimento, trata-se de preocupação meramente acadêmica e de formalismo excessivo. A despeito disso, entendemos que o problema apontado pela não especificação técnica do que são os direitos humanos é o risco de ser - a concepção de direitos humanos - confundida com diversas outras, tais como a caridade, a filantropia, o assistencialismo, etc. Portanto, o fato de se considerar o DIDH, um ramo autônomo, ou não, diante das condições dos direitos humanos no mundo, mais que a questão de fundamentação apontada anteriormente, não muito interessa a esta pesquisa.

Assim sendo, os direitos humanos são, de uma só vez, ramo específico do Direito Internacional Público e uma de suas características ou objetivos fundamentais desde o fim da Segunda Guerra Mundial. No entanto, o movimento de ordenação internacional e os primeiros movimentos em direção à titularidade dos indivíduos como sujeito de Direito Internacional já começara muito anteriormente.

Foi durante o período axial da Historia, como se acaba de assinalar, que despontou a idéia de uma igualdade essencial entre todos os homens. Mas foram

\footnotetext{
${ }^{8}$ BROWNLIE, Ian; CBE; QC; FBA. Principles of international law. $7^{\text {th }}$ Ed. New York: Oxford University Press, 2008. p. 554. : "Many lawyers in academic life refer to an entity described as "International Human Rights Law" which is assumed to be a separate body of norms. While this is a convenient category of reference, it is also a source of confusion. Human Rights problems occur in specific legal contexts. The issues may arise in domestic law, or within the framework of a standard-setting convention, or within general international law. But there must be reference to the specific and relevant applicable law. There is thus the law of a particular state, or the principles of the European Convention on Human Rights, or the relevant principles of general international law. In the real world practice and procedure, there is no such entity as "International Human Rights Law"."
} 
necessários vinte e cinco séculos para que a primeira organização internacional a englobar a quase totalidade dos povos da Terra proclamasse, na abertura de uma Declaração Universal de Direitos Humanos, que "todos os homens nascem livres e iguais em dignidade e direitos." 9

Não é exagero afirmar que, na verdade, os direitos humanos são o produto de todo entendimento das relações sociais entre os seres humanos, cujos princípios tiveram como fonte os valores construídos ao longo do tempo pelas religiões e doutrinas sociais de toda a história da humanidade. Os gregos desenvolveram valores, como a liberdade e a igualdade que se constituem em axiomas da dignidade da pessoa humana e elementos condicionantes para ela. Por sua vez, as religiões, dentre elas o cristianismo, desenvolveram a idéia da dignidade e da importância do homem que foi criado à imagem e semelhança de Deus.

A Idade Média - que compreende o período entre 476 d.C. e 1453 d.C. - é a era de estagnação social nas comunidades humanas, período no qual não se pode observar muita atividade no tocante ao avanço do processo que vem a culminar com o que entendemos hoje por direitos humanos, exceto pelo surgimento do embrião da burguesia e esparsos movimentos de renúncia de poder do Estado em favor do individuo, como é a Carta Magna de 1215.

Importante reparar nos eventos históricos que abrem e fecham a Idade Média, que se inicia com a queda do Império Romano (476 d.C.) e termina com a queda do Império Otomano (1453 d.C.). Durante o Império Romano, fundado em 753 a.C., a Europa, e praticamente boa parte do mundo antigo, esteve sob seu domínio. É dizer que neste imenso território havia um só ordenamento jurídico.

Dispensável mencionar que o desenvolvimento das ciências jurídicas de Roma - que se inicia com a Lei das Doze Tabuas, em 445 a.C. - influenciou diretamente o Direito tal qual o conhecemos hoje. Além de um império que durou por mil e duzentos anos, a multiculturalidade com que tinha que lidar - dada a expansão de seu território conquistado predominante através da guerra, com línguas, costumes, crenças distintas - resultaram, finalmente, na criação, por exemplo, do jus civile (estrito aos cidadãos romanos), do jus gentium (que atingia a todos, independente da nacionalidade - sendo aplicado especialmente aos habitantes estrangeiros do Império) e o jus naturale (que representava os princípios fundamentais e universais de justiça que não podiam ser desobedecidos por

\footnotetext{
${ }^{9}$ COMPARATO, Fabio Konder. A afirmação historia dos direitos humanos. $7^{\mathrm{a}}$ Ed.. São Paulo: Saraiva, 2010. p. 24.
} 
nenhuma autoridade). ${ }^{10}$

Devido à dificuldade de administrar tamanho território, em meados de 200 d.C. o Império entra em declínio e, apesar da tentativa de separá-lo em dois - Império Romano do Ocidente e do Oriente, com capitais em Milão e Constantinopla, respectivamente - Roma perde, gradativamente, sua capacidade bélica, dando oportunidade aos povos bárbaros, principalmente os do norte, de invadirem seus domínios até a total derrocada do Império.

Com o fim do Império Romano, o território europeu - antes sob a jurisdição de Roma - viu-se fragmentado pela ocupação destes povos: a maioria dos francos fixou-se na Gália (atualmente França); os ostrogodos e lombardos em partes da Itália; os anglos e saxões na Bretanha, e assim por diante. Os povos bárbaros viviam em comunidade, plantavam para sua subsistência e eram considerados excelentes caçadores, características que viriam a influenciar na formação da nova ordem social pós-Roma. Este rearranjo no que tange à distribuição geográfica e geopolítica entre os novos Estados que emergiam expandiu-se desencadeando um processo de descentralização política que converteu o feudo na unidade básica do sistema econômico, calcado na grande propriedade de terra, inaugurando o feudalismo.

A sociedade feudal apresentava-se dividida em nobreza, clero e servos. A igreja maior proprietária de terra a época - associa-se à nobreza, justificando a estratificação social nestas sociedades, que impingia aos servos, que, vale apontar, não viviam sob regime de escravidão - a submissão a um regime de obrigações injustas para com os senhores feudais, através das relações de vassalagem, como as banalidades, a captação, a corveia, etc. $^{11}$

Ao difundir a divisão tripartida da sociedade - os que oram (clero), os que guerreiam (nobres) e os que trabalham (servos) -, dizendo que esse modelo correspondia ao da sociedade criada por Deus, o clero ajudava na manutenção dessa organização social. A parte mais poderosa do clero era composta de bispos e abades. Muitos padres (baixo clero) viviam em situação de dificuldade econômica, sendo destinadas a eles geralmente as tarefas mais pesadas dos mosteiros, assim como o atendimento espiritual da massa de camponeses dispersas pelos feudos. ${ }^{12}$

Pois bem, o feudalismo começa a ruir com a aproximação de parte da burguesia ${ }^{13}$ dos reis que, apesar da ancestralidade, eram senhores feudais normalmente menos

\footnotetext{
${ }^{10}$ REZENDE, A. P.; DIDIER, M. T.. Rumos da historia: historia geral e do Brasil. São Paulo: Atual, 2001. p. 63.

${ }^{11}$ REZENDE; DIDIER, 2001, p. 75 et seq.

12 REZENDE; DIDIER, loc. cit.

${ }^{13}$ Proprietários dos burgos, como eram conhecidas as propriedades feudais.
} 
poderosos que outros e tinham seus poderes também limitados pelo clero, que por sua vez, era um entrave para os planos de expansão da burguesia. A centralização social, através do estabelecimento de monarquias nacionais, mostrava-se tentadora para os anseios da burguesia ao possibilitar a unificação da moeda, do exército, da justiça e da cobrança de impostos, mas sobretudo para os reis, que ganhariam poder político de forma centralizada com a perda de influencia da igreja.

O movimento desenvolveu-se até a deterioração das relações entre burguesia e nobreza. O aumento da concentração de poder virá a culminar no surgimento do absolutismo - regime pelo qual todo o poder emana do monarca - e da criação do Estado nacional moderno. O nacionalismo é utilizado pelos monarcas como forma de dar aos súditos um ideal de união, facilitando a sua manipulação e justificando as guerras.

As disputas por territórios ganharam o continente europeu que se viu imerso em uma era de guerras constantes ${ }^{14}$. Entre os séculos XVI e XVIII a Europa testemunhou um quase permanente estado de guerra envolvendo as grandes potências da época. Estas guerras eram basicamente disputas políticas e ideológicas envolvendo católicos e protestantes e os territórios onde estas doutrinas vigeriam.

\begin{abstract}
As lutas tinham como denominador comum à disputa política e ideológica travada entre católicos e protestantes, distinguindo-se dos conflitos anteriores por seu acentuado componente emocional e elevado potencial desagregador. As batalhas feridas entre as facções rivais eram ferozes e desordenadas, tomando a forma, na maior parte das vezes, de insurreições contra governantes de determinado credo. Destacam-se como exemplos desse embates as guerras civis francesas de 1562 s 1598, a revolta dos holandeses contra Felipe II, a rebelião na Escócia contra Maria Stuart, o ataque espanhol na Alemanha, a Revolução Puritana, de 1640 a 1660, e a revolução Gloriosa, 1688 a 1689, na Inglaterra ${ }^{15}$.
\end{abstract}

Destas Guerras, a mais devastadora foi a Guerra dos Trinta Anos (1618-1648) que, na verdade, representa um conjunto de varias guerras, ocorridas sobretudo em território alemão, envolvendo, em momentos diversos, a maioria dos impérios europeus. A Guerra dos Trinta Anos tinha um cunho religioso da disputa entre católicos e protestantes Reforma e Contrarreforma - e trouxe importantes mudanças na reorganização política e territorial do continente Europeu

(...), iniciando-se quando os Habsburgos austríacos quiseram impor catolicismo aos súditos protestantes da Boemia. Essa pretensão desencadeou um conflito generalizado, que lançou o Sacro Império Romano-Germânico contra a França, os Bourbon contra os Habsburgos espanhóis e os príncipes alemães contra o

\footnotetext{
${ }^{14}$ Um exemplo destas guerras é a Guerra dos 100 anos travada entre os reinos franceses e ingleses entre 1337 e 1453.

${ }^{15}$ LEWANDOVSKI, Enrique Ricardo. Globalização, regionalização e soberania. Ed. Juarez de Oliveira. São Paulo. 2004. p. 219.
} 
Imperador. Suecos, dinamarqueses, poloneses, holandeses e suíços acabaram sendo arrastados para o conflito, que envolvia também intrincadas questões dinásticas e acirradas disputas territoriais. ${ }^{16}$

Em 1648, o Tratado de Vestefália ${ }^{17}$ pôs fim a Guerra dos Trinta Anos. Apesar de conhecido no singular, o Tratado de Vestefália é na verdade uma coleção de tratados que encerraram também a Guerra dos Oitenta Anos - entre Espanha e Países Baixos - por exemplo, e redesenharam o mapa geopolítico da Europa, acomodando disputas de cunho dinástico, religioso e territorial por poder na época, envolvendo o Sacro Império Romano Germânico, os Reinos da Espanha, França e Suécia e as Províncias Unidas ${ }^{18}$.

Os Tratados de Westphalia, juridicamente considerados como a base do Direito Internacional contemporâneo, consagraram a derrota do Papa e do Imperador, ampliaram grandemente a liberdade de culto religioso e legalizaram formalmente o nascimento de novos Estados soberanos, assim como lançaram os primeiros elementos de um "Direito Publico Europeu", sendo explicitamente reconhecidos os princípios da soberania e da igualdade entre os Estados como o fundamento das relações internacionais. Implicitamente, foi também reconhecido o principio do equilíbrio entre os Estados. ${ }^{19}$

Entende-se por Tratado qualquer acordo assinado entre Estados que geram direito e obrigações entre eles, ou no cenário atual, também entre Estados e Organizações Internacionais, segundo dispõe a Convenção de Viena sobre o Direito dos Tratados ${ }^{20}$, adotada em 1986, em conferencia convocada pela Assembleia Geral da ONU. Segundo ela tratado significa:

\begin{abstract}
"um acordo internacional regido pelo Direito Internacional e concluído por escrito: (i) entre um ou mais Estados e uma ou mais organizações internacionais; ou (ii) entre organizações internacionais, quer conste de um instrumento único, quer de dois ou mais instrumentos conexos, qualquer que seja sua denominação particular."
\end{abstract}

Desta feita, acordo, declaração, pacto, convenção, etc., todos são sinônimos de tratado, que podem ser bilaterais ou multilaterais (coletivos). À época, a prática de tratados

\footnotetext{
${ }^{16}$ LEWANDOVSKI. p. 221. "O resultado da guerra em termos humanos e econômicos, foi catastrófico. Segundo estimativas, a população da Alemanha e da Áustria viu-se reduzida em mais de sete milhões de pessoas. A Boemia passou três milhões para 800 mil habitantes, sendo que, dentre 35 mil cidades, cerca de 29 mil forma abandonadas durante o conflito. No Império como um todo, centenas de centros urbanos ficaram sem uma viva alma. De acordo com relatos da época, era possível viajar por dezenas de quilômetros sem deparar com uma vila ou casa. Os campos e fazendas foram abandonados em razão de pilhagens e dos saques. A indústria e o comercio entraram em colapso, causando a ruina de nobres e burgueses. As doenças, como o tifo, a disenteria, o escorbuto e a peste grassavam por toda a parte, dizimando regiões inteiras."

${ }^{17}$ Nome da região onde foi assinada no sul da Alemanha dos dias atuais.

${ }^{18}$ Formada pelas sete províncias do norte dos Países Baixos: Frisia, Groninga, Güeldres, Holanda, Overijssel, Utrecht y Zelanda, agrupadas desde a União de Utretch (1579).

${ }^{19}$ CRETELLA NETO, José. Teoria geral das organizações internacionais. $2^{\mathrm{a}}$. ed. São Paulo: Ed. Saraiva, 2007. v. 1, p. 2.

${ }^{20}$ Convenção de Viena sobre o Direito dos Tratados entre Estados e Organizações Internacionais ou entre Organizações internacionais, adotada em 21.03.1986, em conferencia convocada pela Assembleia Geral da ONU, art. 2.1.
} 
multilaterais ainda não havia se desenvolvido ${ }^{21}$, também por esse motivo o Tratado era na verdade uma série de tratados bilaterais, todos com o objeto a paz. Tampouco se podia falar nesse tempo em organizações internacionais universais.

Estes Tratados tiveram fundamental importância para o desenvolvimento do Direito Internacional ao passo que inauguram a Paz de Vestphalia, fundada nos princípios da soberania e da igualdade entre os Estados, e da integralidade territorial como componente destes, frente à idéia vigente durante o feudalismo de que os territórios eram patrimônio hereditário, estabelecendo o conceito de Estado-nação. ${ }^{22}$

Primeiramente, os tratados entre os Estados regulavam as relações jurídicas entre eles sem que os indivíduos tomassem parte na titularidade de Direito Internacional - o que só viria acontecer sob a égide da ONU - e tinham, primordialmente, a paz como objeto.

Muito bem, primeiramente, cumpre formar uma idéia básica sobre o conceito de Estado moderno, cujo uso da palavra se deve a Maquiavel $^{23}$. Estado é uma organização jurídica coercitiva vigente num território delimitado, para determinada comunidade humana, num determinado período de tempo. Para Estado há três concepções fundamentais: (i) concepção organicista, segundo a qual o Estado é independente dos indivíduos e anterior a eles; (ii) concepção atomista ou contratualista, segundo a qual o Estado é uma criação dos indivíduos e (iii) concepção formalista, segundo a qual o Estado é uma formação jurídica. ${ }^{24}$ As duas primeiras alternaram-se no pensamento ocidental ao longo do tempo enquanto a terceira é moderna e formulada recentemente.

A idéia de Estado, primeiramente, associa-se a idéia de comunidade, como um grupo social residente em determinado território no mesmo período de tempo. Então, originariamente, o Estado carregava os conceitos de grupo social e território que, com o desenvolvimento da concepção elaborada por juristas e filósofos - resultou na definição dos três elementos ou propriedades características que definem o definem: soberania, povo e território. Este é o espaço físico geográfico delimitado onde certo ordenamento jurídico soberano é estabelecido e se desenvolve. O território é caracterizado pela afirmação

\footnotetext{
${ }^{21}$ CRETELLA NETO, 2007, p. 2. E acrescenta: "Na realidade, o primeiro tratado multilateral da Historia que assim merece ser denominado foi o Tratado de Paz de Paris, de 30.03.1856, celebrado ao termino da Guerra da Crimeia, na qual a Rússia fora derrotada pelas forças da aliança entre a França e a Grã-Bretanha, apoiadas pelo Piemonte-Sardenha e pela Turquia."

${ }^{22}$ LEWANDOVSKI, 2004. p. 221: "Com efeito, os acordos de Munster e Osnabruck colocaram um paradeiro a pretensão da igreja e dos Habsburgos de manter uma Europa politica e ideologicamente unificada, livre da heresia protestante, sob uma monarquia católica, dando origem, ao revés, a um sistema laico de Estados independentes regidos por governos e credos distintos."

${ }^{23}$ Cf MAQUIAVELII, Nicola. O principe. Trad. Livio Xavier. 27ª Ed. Rio de Janeiro: Ediouro, 1996.

${ }^{24}$ ABBAGNANO, Nicola. Dicionário de filosofia. $5^{\mathrm{a}} \mathrm{Ed}$. Trad. Ivone Castilho Benedetti. São Paulo: Martins Fontes, 2007. p. 364.
} 
espacial de onde este ordenamento opera e está condicionado, sobretudo, ao reconhecimento internacional para que tenha validade, caso contrário, em não havendo este reconhecimento de que um território pertença a um determinado Estado, frequentemente, a guerra decide.

Já povo é a comunidade humana que vive na mesma localização geográfica e sob a mesma ordenação jurídica. O conceito de povo não deve ser confundido com o de nação, que soma ao primeiro características adicionais como causas naturais e tradicionais como o clima, religião, línguas, usos e costumes, etc. Portanto, povo deve ser entendido como o conjunto de seres humanos vivendo sob determinado ordenamento jurídico. Já nação, o grupo de pessoas que somam atributos extras que o simples fato de serem humanos e de viverem sobre certo ordenamento ${ }^{25}$.

O conceito de nação desempenhará papel de um dos protagonistas no caminho percorrido pela concretização dos direitos humanos, frequentemente, de maneira negativa ${ }^{26}$. Este conceito está intimamente ligado ao conceito de soberania e surgiram na França nos momentos de intensa turbulência política que antecederam a Revolução de 1789. A este respeito:

\begin{abstract}
Arrimando a soberania num outro esteio, surgiu na Franca, nos momentos de intensa turbulência política que antecederam a Revolução de 1789, o panfleto intitulado "O que e o Terceiro Estado?", em que o padre católico Emmanuel Sieyes denunciava os privilégios da aristocracia, a qual chamava de "casta" parasitaria que vivia à custa da "nação autêntica". E, respondendo a questão formulada no titulo do folheto, afirmava que o Terceiro Estado era "tudo", ou seja, uma "nação completa", porquanto com o seu trabalho sustentava a sociedade inteira. ${ }^{27}$
\end{abstract}

Para o religioso francês, a unidade do estado não está baseada na idéia de povo, enquanto reunião dos indivíduos vivos, conforme defendia Rousseau, mas na idéia de “nação" enquanto expressão dos interesses permanentes de uma dada comunidade, não se confundindo com o conjunto de pessoas que a compõem num determinado momento histórico. Para Rousseau, todos os indivíduos têm o direito de participar do processo político, inaugurando a ideia de igualdade política entre os cidadãos, ao passo que para Sieyes a nação pode atribuir a quem quiser o poder de falar por ela ${ }^{28}$. Assim sendo,

\footnotetext{
${ }^{25}$ A diferença entre povo e nação esta na titularidade de direitos. Como exemplo, o caso dos imigrantes e nacionais. O povo brasileiro, por exemplo, é formado por nacionais e imigrantes. Um estrangeiro que vive no Brasil não detém direitos políticos - reservado somente aos nacionais - porém detém o conjunto de direitos humanos gerais como qualquer cidadão nacional.

${ }^{26} \mathrm{O}$ nacionalismo sempre fui usado como pretexto para justificar guerras.

${ }^{27}$ LEWANDOVSKI, 2004. p. 228.

${ }^{28}$ Ibid., p. 229.
} 
Rousseau defendia que a soberania se dava através de cada individuo, sendo os representantes políticos, mero mandatários do poder destes.

Logo da Revolução Francesa os primeiros encarregados do processo de elaboração de um novo Estado (os publicistas) compreenderam o caráter radical das ideias de Rousseau que levariam, se aplicadas literalmente, as massas populares ao poder, com o risco de instauração da anarquia, por isso trataram de incluir, no primeiro texto jurídico que resultou do movimento, a "Declaração dos Direitos do Homem e do Cidadão", o princípio segundo o qual "toda a soberania reside essencialmente na nação", que esperaria a vez de ser trocada pelo "povo" na Constituição de 1793, tal como o rei, antes, havido sido substituído por aquela. $^{29}$

A soberania é o poder vigente e supremo do Estado de criar ou abolir leis em seara nacional, ou seja, encerrada dentro da jurisdição territorial conferida a ele, sem intervenção de nenhum outro Estado, além da autonomia de tratar internacionalmente. Ela vigorou como instituto do Direito das Gentes, sendo, por um lado, obstáculo para a expansão da sociedade planetária e, ao mesmo tempo, elemento capacitador da construção da comunidade internacional com um ordenamento jurídico supra-estatal. A soberania, em verdade, não nasce com os Tratados de Vestefália, mas sim são aperfeiçoados por estes.

\footnotetext{
Cumpre notar que a noção de soberania, como um poder incontrastável dos governantes, não surgiu com a Paz de Westphalia, embora tenha ficado formalmente estabelecido nesta o principio "rex est imperator in regno suo", segundo o qual o rei em seus domínios não esta sujeito à vontade política de quem quer que seja. Em verdade, bem antes dos acordos que puseram fim a Guerra dos Trinta Anos já se reconhecia a existência de uma pluralidade de soberania estatais, como a da Espanha, depois da união de Castella e Aragão, a da Inglaterra, após a guerra das Duas Rosas, e a da França, em seguida a Guerra dos Cem Anos. A grande novidade é que, a partir da assinatura dos tratados, passou-se a admitir que a soberania, embora concebida ainda como um poder absoluto no plano interno, sujeita-se à limitações no âmbito externo pela vontade política de outros Estados, num contexto regido pelas normas de direito internacional. ${ }^{30}$
}

Pois, a soberania garante a livre criação ou alteração do ordenamento jurídico em território nacional. Sem embargo, ela garante também a titularidade de tratar internacionalmente, ou seja, com os outros Estados reconhecidos como tais através de tratados, que são, dessa maneira, a maior fonte do Direito Internacional Publico.

Grotius, em seu Direito da Guerra e da Paz, de 1625, faz a noção de soberania derivar do poder civil, que defendia como a faculdade moral de governar um Estado

\footnotetext{
${ }^{29}$ LEWANDOVSKI, 2004. p. 229.

${ }^{30}$ LEWANDOVSKI, 2004, loc. cit. .
} 
através de um poder supremo, de vontade incondicionada.

Do relacionamento dessa vontade incondicionada com outras de igual natureza, retirou o seu conceito de direito internacional, afirmando que, "assim como as leis de cada Estado tem em vista a utilidade deste, também podem originar-se, por consentimento, certos direitos entre todos os Estados ou entre muitos deles/ e uma vez assim nascidos e evidente que objetivam não os Estados individualmente considerados, mas a grande comunidade de Estados. Antecipando-se, pois, em quase um quarto de século aos tratados de Westphalia, Grotius concebeu a ordem jurídica internacional como resultante da interação de Estados soberanos. ${ }^{31}$

No século XVIII, Kant desenvolve a ideia, por pressupor, o Direito Internacional, a existência distinta de inúmeros Estados independentes - situação que se assemelha a um estado de guerra - que os governantes buscassem constituir uma federação de Estados, por acreditar que a espécie humana possui um projeto de instaurar na Terra um governo legitimo, republicano e universal. ${ }^{32}$ Tem inicio o movimento do cosmopolitismo que aguardaria até que os Estados nacionais se consolidassem, o que só ocorreu já no século XIX.

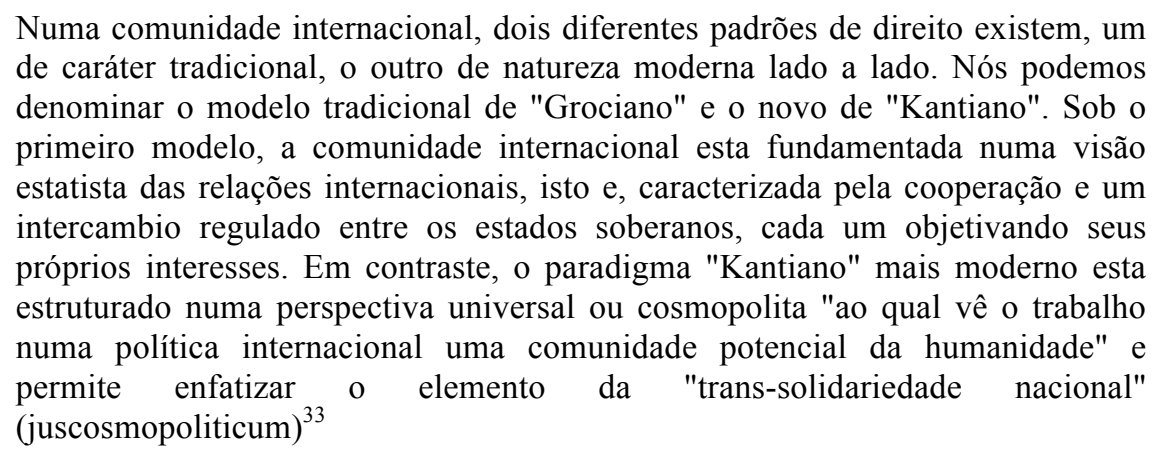

O instituto da soberania, portanto, uma vez reconhecido em esfera internacional, teve importância fundamental na conformação da noção de Estado que temos hoje, como foi também o maior obstáculo ${ }^{34}$ para o desenvolvimento do Direito Internacional Público, e dos Direitos Humanos, por ser, a este tempo, absoluta e não estar submetida a nenhuma forma de poder superior. Portanto, podemos afirmar de plano que o desenvolvimento dos

${ }^{31}$ LEWANDOVSKI, 2004, p. 241 "Esse conceito de direito internacional, que baseava a convivência dos Estados no consenso e não na força, na razão e não no arbítrio, foi desenvolvido em uma época em que a Europa encontrava-se convulsionada pelas lutas religiosas. Por isso, representou uma verdadeira revolução no pensamento jurídico então vigente, sobretudo por submeter a barbárie da guerra à lei e à moralidade, cujas regras deveriam estender-se a todos indistintivamente, inclusive aos infiéis. Daí advém a fama de Grotius como um dos precursores do moderno "Jus gentium."",

${ }^{32}$ LEWANDOVSKI, 2004, loc. cit.

${ }^{33}$ MENEZES, C.A.; CANÇADO TRINDADE, A. A.; PEREIRA, A. C. A. (Orgs) Novas Perspectivas do Direito Internacional Contemporâneo: Estudos em homenagem ao professor Celso de Albuquerque Mello. $1^{\text {a }}$ Ed. Rio de Janeiro: Renovar, 2008. p. 1.087.

${ }^{34}$ Como vem sendo até hoje. Como exemplo, a declaração de ministros do Supremo Tribunal Federal brasileiro sobre não cumprir a sentença condenatório da Corte Interamericana de Direitos Humanos no caso do Araguaia (em 2011) por afirmarem que fere a soberania nacional. 
direitos humanos ocorre junto com a historia da limitação do poder dos Estados e início da efetivação do individuo como sujeito de Direito Internacional. Tudo isto somente no final do século XIX e início do século XX.

Simultaneamente ao processo embrionário da criação do Direito Internacional contemporâneo, surgem os mais importantes que concediam direitos aos cidadãos em detrimento ao poder dos Estados, iniciando o processo gradual de perda da soberania absoluta ao reconhecer direitos fundamentais. Os séculos XVII e XVIII são os séculos dos grandes instrumentos que compõem a historia dos direitos humanos como o (i) Habeas Corpus Act, de 1679; (ii) a Declaração dos Direitos de 1689 - resultado direto da Revolução Gloriosa da Inglaterra; (iii) Declaração do Estado norte-americano da Virgínia, em 1776 e (iv) Declaração Francesa dos Direitos dos Homens e Cidadãos, em 1789. Esses documentos tiveram influência marcante em todo o ordenamento internacional e são marcos na construção histórica dos direitos humanos, frutos de revoltas e revoluções responsáveis pela a ascensão de classes desfavorecidas a alguns direitos frente ao Estado. No caso dos documentos ingleses - Habeas Corpus Act e a Declaração de Direitos (Bill of rights) - o primeiro era a garantia judicial à livre locomoção contra a ação arbitrária do Estado, como remédio ou ação preventiva, enquanto o segundo, ineditamente, põe fim ao regime da monarquia absolutista, transferindo parte do poder do Estado para o Parlamento.

A Declaração de Independência dos EUA, em 1776, além de, obviamente, livrar a colônia das injustas relações coloniais - principalmente dos pesados impostos taxados pela metrópole - tem grande importância por ser ela a pioneira na historia da política moderna a afirmar os princípios democráticos ${ }^{35}$. Ou seja, não mais imperadores, monarcas, nobres são os únicos exercedores de direitos políticos, mas sim todo e qualquer cidadão passaria a fazer parte do Estado da mesma maneira, avançando a idéia e o principio da igualdade e da inalienabilidade ao reconhecer que "todos os homens são criaturas iguais, dotadas pelo seu Criador de certos direitos inalienáveis, entre os quais a vida, a liberdade e a busca da felicidade" ${ }^{36}$. Vale observar, entretanto, que o principio da igualdade não é proposto integralmente, uma vez que os escravos estavam fora desta nova ordem cidadã. Sem embargo, por garantir direitos políticos, a Declaração de Independência estadunidense avança na idéia de soberania popular em detrimento da soberania nacional.

$\mathrm{Na}$ verdade, a idéia de uma declaração à humanidade esta intimamente ligada ao

\footnotetext{
${ }^{35}$ Cf COMPARATO, 2010, p. 117-118.

${ }^{36}$ Declaração de Independência dos Estados Unidos da América, de 1776.
} 
principio da nova legitimidade política: a soberania popular. Uma nação só está legitimada a auto-afirmar sua independência, porque o povo que a constitui detém o poder político supremo. ${ }^{37}$

A Independência Estadunidense também é de fundamental importância para esta dissertação ao notar que nasce ali uma nova potência mundial que, num prazo de 150 anos, tornar-se-á a maior potencia econômica e militar do mundo. Estes anseios já aparecem na própria Declaração que expressa, em vez da criação de uma nova nação na comunidade internacional, a criação de uma nova potência.

Quando, no decurso da história humana, torna-se necessário a um povo romper os laços políticos que o vincularam a outro, bem como assumir, entre as potências mundiais, a posição separada e igual a que o habilitam as leis da natureza e do deus da natureza, o respeito devido às opiniões da humanidade, obriga-o a declarar as causas que impelem à separação. ${ }^{38}$

Com a independência declarada, a opção por um sistema de poder descentralizado entre as muitas ex-colônias inglesas desencadeou uma serie de novas Declarações de Direitos. Dentre estas, destaque para a Declaração do Estado da Virginia, em 1776, cuja abertura influenciará diretamente, treze anos mais tarde, a Declaração Francesa.

A Declaração Francesa é talvez o documento histórico mais citado para a conflagração dos direitos humanos como são hoje, a despeito do entendimento pacífico que são eles o resultado da combinação de diversas conquistas ao longo da história. Depois dela o termo "revolução" ganha novo conceito passando a ser usado para indicar uma “renovação completa das estruturas sociopolíticas, a instauração 'ex novo' não apenas de um governo ou de regime político novo, mas de toda uma sociedade, no conjunto de relações de poder que compõem a sua estrutura" ${ }^{39}$.

As ideias da Revolução Francesa tomaram o mundo imediatamente inspirando levantes contra regimes opressores em escala global. Da tríade Igualdade, Liberdade e Fraternidade, o maior avanço foi quanto à primeira. A fraternidade, seria o espírito que regeria esta nova sociedade e a liberdade era implícita com o fim dos estamentos sociais. Já o princípio da igualdade garantia ao cidadão comum - os pobres e miseráveis - que, por um olhar romântico, derrubaram o regime monárquico opressor, capaz de viver na abundancia enquanto seu povo vivia na miséria. A Revolução pôs fim às servidões feudais, emancipou os judeus, aboliu todos os privilégios religiosos, proibiu a escravidão nas colônias francesas, amalgamando a igualdade como principio fundamental de direito.

\footnotetext{
${ }^{37}$ COMPARATO, 2010, p. 118.

${ }^{38}$ Declaração de Independência dos Estados Unidos da América, de 1776.

${ }^{39}$ Ibid., p. 141.
} 
Em 1815, os Estados europeus avançaram para resolver as questões de paz através de soluções coletivas ao elaborar, durante o Congresso de Viena sobre o Direitos dos Tratados, um "Instrumento Geral", que englobava todos os tratados bilaterais concluídos e em vigor entre os participantes, dando assim mais um passo importante para o desenvolvimento do Direito das Gentes.

Cem anos mais tarde, no final do século XIX, diversos eventos marcaram a nova ordem mundial como a Revolução Industrial e a segunda era do colonialismo - movimento no qual os países industrializados buscavam matéria prima em outras regiões do planeta que não passavam pelo mesmo processo de transformação econômica e social. $\mathrm{O}$ neocolonialismo (ou imperialismo) estabeleceu um novo desenho na ordem internacional, tendo como seus principais atores colonizadores a França e a Inglaterra, e seus principais destinos os continentes asiático e africano.

Os dois processos geraram progresso econômico e social para a Europa. No entanto, a paz que se poderia pretender pelo acumulo de riquezas e o avanço dos últimos três séculos no tocante ao direito internacional não foi observada. Pelo contrário, o progresso econômico acirrou as disputas entre as nações do velho mundo e criou classes economicamente desfavorecidas dentro das sociedades europeias ao passo que a riqueza se concentrava nas mãos da aristocracia. Neste rearranjo da ordem social, encontrava-se, de um lado, uma classe de operários dispostos a se unir "internacionalmente" e, de outro, grupos poderosos defendendo a idéia de uma nação-potência. Nos países que, por problemas internos, não aderiram ao neocolonialismo a questão nacional ganhou uma roupagem especial.

Enquanto na Rússia e nos países vizinhos, desenvolveu-se uma idéia do paneslavismo - buscando unir os povos eslavos desfavorecidos socialmente - que culminaram na Revolução Russa, em 1917, por exemplo - na Alemanha e na Áustria, a idéia de um pangermanismo $^{40}$, que era, em resumo, a idéia de reunir todo o povo germânico ${ }^{41}$, disperso por uma grande área da Europa central e oriental sob um grande e poderoso Estado. Estes movimentos geravam tensão entre os outros Estados europeus e a iminência de novos confrontos bélicos.

Apesar da tensão caminhar nesta direção, foi no fim do século XIX e início do século

\footnotetext{
${ }^{40}$ A ideia de uma super nação imperial como reunificação dos povos germânicos separados desde o império romano e principalmente decorrente das disputas por poder na Europa, como mencionamos anteriormente.

${ }^{41}$ Como vimos os povos Eslavos e Germânicos eram povos considerados bárbaros no Império Romano.
} 
XX que o movimento em direção a um Direito cosmopolita, ou seja, um ordenamento supra internacional, trans-solidário, teve seu momento de maior atividade com o surgimento das organizações internacionais como o Comitê Internacional da Cruz Vermelha (CICV), em 1863, o International Agriculture Institute, fundado em 1905 e que é predecessor da Food and Agriculture Organization (FAO) e a Organização Internacional do Trabalho (OIT), em 1919.

A institucionalização das organizações internacionais foi um grande passo em direção à conformação do Direito Internacional. As organizações preveem em seus tratados, fatos e condutas que virão a materializar-se na realidade e atribuir- lhes consequência, inclusive, entre elas, sanções internacionais. Exercem, pois, grande influência na soberania e independência nacional, não se podendo sustentar mais a idéia de soberania absoluta.

O Direito Internacional apresentava até o início do século passado uma consistência costumeira exceto por princípios como o da boa-fé e do pacta sunt servanda. Conhecido como o Direito Internacional westfaliano, este é o período embrionário do Direito Internacional contemporâneo, que, com a ONU, ramifica-se, entre outros, no Direito Internacional dos Direitos Humanos. O sistema westfaliano tinha como único sujeito de Direito o Estado soberano. Respeitava os princípios da igualdade entre as partescontratantes, a autodeterminação e a reciprocidade. Todos vinculados ao instituto da soberania absoluta. Ademais, os tratados anteriores ao advento das organizações internacionais tinham como objeto, primordialmente, a paz. Com estes novos atores do Direito Internacional - as organizações internacionais - os objetos variam como regras laborais, alimentação ou o humanitarismo.

Este período de legalização das relações internacionais concretiza o Direito das Gentes. A adoção de tratados multilaterais afirma-os como fonte maior de direito internacional, a despeito do caráter costumeiro que sempre caracterizou as relações 
internacionais $^{42}$.

Concomitantemente a este redesenho da ordem internacional, o inicio do século XX é marcado também pelas primeiras aparições dos direitos humanos tidos de segunda geração em ordenamentos nacionais. Os direitos econômicos e sociais surgiram na história da positivação dos direitos humanos com a (i) Constituição Mexicana, 1917; (ii) Constituição da Rússia de 1918 e (iii) Constituição da Republica de Weimar, de 1919.

Sem embargo, o avanço do Direito das Gentes observado neste período não era ainda suficiente para manter a paz entre as nações. O militarismo, a soberania nacional absoluta e o incremento do sentimento nacionalista, utilizado em ampla escala como meio eficaz de conquistar apoio popular interno contra as "intervenções" na soberania nacional, eram ingredientes que maturavam um novo conflito bélico. Estes valores tomavam as sociedades e eram passados inexoravelmente através da educação.

(...) Pode-se falar de uma verdadeira religião da pátria, inculcada pela escola laica (por volta de 1880, as crianças aprendiam a manejar armas, usando espingardas de madeira, desde a escola primária) e ensinada também nas instituições religiosas. O nacionalismo é um "valor" partilhado tanto pela direita quanto pela esquerda (contestado apenas por uma pequena minoria desta última), o que explica o malogro total do internacionalismo de 1914. (...) ${ }^{43}$

Assim, pelas condicionantes apresentadas, somadas ao incremento na produção armamentista e ao aumento da disputa entre as nações - especialmente disputas na região dos Bálcãs - em 28 de julho de 1914, os austríacos declaram guerra à Sérvia. Com a intervenção da Rússia, a Alemanha declara guerra à esta, e três dias depois, à França, deflagrando, enfim, a Primeira Guerra Mundial.

A Guerra teve como protagonistas a Tríplice Entente, composta pelo Império Britânico, França, Império Russo, EUA (somente em 1917) e aliados, contra as potencias centrais, lideradas pelo Império Alemão, Império Austro-Húngaro e Império TurcoOtomano que, após a Guerra, colapsaram, rearranjando a geopolítica europeia mais uma

${ }^{42}$ GOLDSMITH, Jack L. e POSNER, Eric A. The limits of international law. New York: Oxford University Press, 2005. P. 21. Em continuação: "Political scientists and some international lawyers maintain that the late twentieth century witnessed two novel and related trends: the "legalization" of international relations (Goldstein et al 2000, 386) and the rise of multilateral institutions (Abott and Snidal 1998; Koremenos et al. 2001).. This view assumes that international law consists primarily of formal international organizations made by multilateral treaty, such as the United Nations, the World Trade Organization, the Law of the Sea regime, and the European Union. This view betrays a lack of historical perspective. For there is another form of international law besides treaties: customary international law. Customary international law is usually defined as the customary practices that states follow from a sense of legal obligation. It has the same legal force under international law as treaties. Customary international law has always regulated important elements of international relations and has always been multilateral in the sense of purporting to bind all or almost all states.

${ }^{43}$ ARIES, P. e Duby, G. (Orgs) Historia da vida privada. v. 5. São Paulo: Companhia das Letras, 2009. p. 208. 
vez.

Como saldo, a Primeira Guerra Mundial deixou aproximadamente 19 milhões de mortos, entre militares e civis, dentre os quais, estima-se quase um milhão de armênios mortos em campos de concentração durante os anos finais do Império Turco-Otomano - de 1299 a 1923 -, acusados de serem aliados da Rússia. Apesar de comprovado historicamente, a Turquia recusa- se até hoje a reconhecer este genocídio.

Em 1918, cinco tratados de paz selaram o fim da guerra com destaque para o Tratado de Versalhes, em 1919, que fundou a Sociedade das Nações. A Sociedade ou Liga das Nações "tratava-se de uma associação intergovernamental, de caráter permanente, de alcance geral e com vocação universal, baseada nos princípios de segurança coletiva e da igualdade entre Estados soberanos"44, encerrando para muitos a paz westfaliana.

É a primeira tentativa de criar uma organização internacional com objetivo de manter a paz através de mecanismos jurídicos. Inicialmente contava com 32 países, atingindo no seu auge 54 membros. Os membros originários eram basicamente as potencias vitoriosas na Guerra das Trincheiras - como também é conhecida a Primeira Guerra Mundial - e que tinham status privilegiado.

Com o objetivo de manter a paz, a Liga das Nações tinha três linhas de ação: (i) fazer cumprir o Tratado de Versalhes; (ii) criar um clima de confiança suficiente para avançar nas relações internacionais e (iii) dedicar esforços para aumentar a cooperação internacional no campo da saúde, da cooperação técnica e laboral. Esta última por reconhecer a estreita relação entre paz e justiça social. A idéia dos direitos humanos universais, no entanto, restaram de fora do planejamento internacional pós Primeira Guerra.

Diversos motivos são apontados para o insucesso da Liga das Nações dentre os quais a não aprovação do Tratado de Versalhes pelo Congresso estadunidense, impedindo os EUA de continuarem participando desta iniciativa, deslegitimando a Liga como órgão universal. Porém, o maior obstáculo foi que, na verdade, a Sociedade das Nações foi mais utilizada como um tribunal permanente para a Alemanha (derrotada na Primeira Guerra Mundial). Tal disfunção resultou em um maior isolamento da derrotada e consequente enfraquecimento da sua economia, agravada pela quebra da bolsa nova iorquina de 1929, evento que imergiu o mundo ocidental em uma crise econômica nunca antes

\footnotetext{
44 SEITENFUS, Ricardo. Manual das organizações internacionais. Porto Alegre: Livraria Casa do Advogado, 2008, p. 105.
} 
experimentada. Tudo isso criou terreno fértil para o desenvolvimento da política social nacionalista que culmina na ascensão de Hitler ao poder, como o líder do regime nazista ${ }^{45}$, apoiado pela classe empresarial e aristocratas, que viam no movimento a melhor defesa contra o movimento comunista crescente na Europa e as desordens sociais. Vale lembrar que a autocracia não é exclusividade da Alemanha, mas sim uma onda que toma a Europa na década de 30, com o franquismo na Espanha, o fascismo na Itália e o Stalinismo na URSS.

O regime nazista é marcado neste primeiro momento pela supressão dos direitos civis e o fim das liberdades fundamentais. Sob o comando do Führer (autoridade máxima e plena do regime), o Estado nazista controlava tudo. A delação e a perseguição operavam nas universidades, na imprensa e no meio artístico. Eliminando opositores, Hitler ganhou status de imperador e a nova ordem não hesitava em mandar aos campos de concentração, os comunistas, socialistas, ou qualquer opositor a ela.

\section{Eliminando os opositores e elevando a autoestima da maioria da população por meio da pregação da idéia de superioridade da raça ariana, Hitler preparou o caminho para a ampliação dos territórios e do poder dos alemães. (...)Incitando o ódio ao acordo de paz de Versalhes, Hitler induzia no povo alemão o desejo de resgatar as perdas sofridas ao termino da Primeira Guerra. ${ }^{46}$}

Com o avanço da política nazista baseada nas pretensões imperiais de Hitler, a Alemanha se militariza e a indústria bélica, de certa maneira, ameniza o problema do desemprego, rendendo ao regime ainda mais apoio popular. Os preparativos armamentistas contaram com o silêncio das potências à época que, quando despertaram, já era tarde demais para se evitar um conflito armado.

Com a invasão da Polônia pela Alemanha, em 1939, a França e a Inglaterra declaram guerra àquela, dando inicio, para muitos, à Segunda Guerra Mundial. Nos dois anos iniciais, a Alemanha conquistou boa parte da Europa ocidental, restando a Inglaterra como única potencia capaz de fazer frente ao Império Alemão, posto que a França estava sob domínio nazista, e a União Soviética se colocava neutra no conflito.

Do retrocesso no campo dos direitos fundamentais através da supressão de direitos pelo regime nazi, que depois transformaram-se em crimes de guerra, o que mais marcou foi, sem sombra de duvidas, a perseguição ao povo judeu, que teve absolutamente todos os seus direitos subtraídos, sendo reduzidos à categoria de não-humanos, somente devido à

\footnotetext{
${ }^{45}$ Nazi é a sigla em alemão para Partido Nacional dos Trabalhadores Alemães (Nationalsozialistische Deutsche Arbeiterpartei).

${ }^{46}$ REZENDE; DIDIER, 2001, p. 532.
} 
sua origem étnica. Trata-se do auge do absoluto descaso ao direito à vida e desprezo pelo principio de dignidade, noção de fraternidade, ou do que se entende por humanidade. A Segunda Guerra marcou a historia da humanidade como nenhuma outra.

Os motivos que levaram à perseguição ao povo hebreu dão margem à muitas interpretações, sendo a de que era utilizada como pretexto para controlar as massas, exortando ao mesmo tempo a raça ariana ${ }^{47}$, a mais repetida. Neste sentido:

Muitos ainda julgam que a ideologia nazista girou em torno do antissemitismo por acaso, e que desse acaso nasceu a política que inflexivelmente visou o resultado derradeiro, e, mais ainda, diante do seu efeito, constituído pelos sobreviventes sem lar e sem raízes, deu à "questão judaica" a proeminência que ela passou a ocupar na vida política diária. O que os nazistas apresentaram como sua principal descoberta — o papel dos judeus na política mundial — e o que propagavam como principal alvo - a perseguição dos judeus no mundo inteiro - foi considerado pela opinião pública mero pretexto, interessante truque demagógico para conquistar as massas. ${ }^{48}$

O social-nacionalismo surge como protagonista desta ação persecutória mas as características do mecanismo alemão têm, além do nacionalismo, outra dimensão ${ }^{49}$.

Os nazistas não eram meros nacionalistas. Sua propaganda nacionalista era dirigida aos simpatizantes e não aos membros convictos do partido. Ao contrário, este jamais se permitiu perder de vista o alvo político supranacional. $O$ "nacionalismo" nazista assemelhava-se à propaganda nacionalista da União Soviética, que também é usada apenas como repasto aos preconceitos das massas. Os nazistas sentiam genuíno desprezo, jamais abolido, pela estreiteza do nacionalismo e pelo provincianismo do Estado-nação. Repetiram muitas vezes que seu movimento, de âmbito internacional (como, aliás, é o movimento bolchevista), era mais importante para eles do que o Estado, o qual necessariamente estaria limitado a um território específico. E não só o período nazista mas os cinquenta anos anteriores da história antissemita dão prova contrária à identificação do antissemitismo com o nacionalismo. Os primeiros partidos anti-semitas das últimas décadas do século XIX foram os primeiros a coligar-se em nível internacional. Desde o início, convocavam congressos internacionais, e preocupavam-se com a coordenação de atividades em escala internacional ou, pelo menos, inter-européia. ${ }^{50}$

O antissemitismo crescia consecutaneamente ao declínio do Estado-nação. Antagonicamente, ao mesmo tempo o nacionalismo ou, mais apropriadamente, o espírito imperial alemão, era usado como fundamentação para a implementação da política do terror com o apoio popular. Sem embargo, a análise sobre as razões do antissemitismo

\footnotetext{
${ }^{47}$ Segundo o Dicionário Aurélio: “Ariano. Adj.1. Relativo ou pertencente aos árias. 2. Da raça dos árias. 3. Entre os modernos teóricos do racismo alemão, diz-se dos europeus de raça supostamente pura, descendentes dos árias, sem ascendência judaica. (...)"

${ }^{48}$ ARENDT, Hannah. As origens do totalitarismo. Trad. Roberto Raposo. São Paulo: Companhia das Letras, 1989, p. 23.

49 ARENDT, 1989, loc. cit. Segue a autora: "Uma dessas apressadas explicações identifica o antissemitismo com desenfreado nacionalismo e suas explosões de xenofobia. Mas, na verdade, o antissemitismo moderno crescia enquanto declinava o nacionalismo tradicional, tendo atingido seu clímax no momento em que o sistema europeu de Estados- nações, com seu precário equilíbrio de poder, entrara em colapso.”

${ }^{50}$ ARENDT, 1989, loc. cit. .
} 
alemão torna-se ainda mais instigante ao se observar a dimensão dos efeitos causados por ele.

Tais discrepâncias entre a causa e o efeito constituem ultraje ao bom senso a tal ponto que as tentativas de explanar o anti-semitismo parecem forjadas com o fito de salvar o equilíbrio mental dos que mantêm o senso de proporção e a esperança de conservar o juízo ${ }^{51}$.

A alegação de que os judeus dominavam a economia vivendo da especulação financeira gerada pelo trabalho do povo alemão, segundo Hannah Arendt, não prospera, já que os judeus viviam processo de declínio econômico e social sendo até previsto o desaparecimento do judaísmo alemão em questões de décadas ${ }^{52}$.

A perseguição aos judeus observou três fases, ou soluções para o "problema" segundo os nazistas: (i) expulsão; (ii) concentração e (iii) execução. Os campos de concentração nazistas, apesar de não ser uma inovação, e, originariamente criados para manter aqueles que se opunham ao regime passando posteriormente a receber os judeus (como também os ciganos, homossexuais, etc.), assombram a consciência humana até hoje pelos horrores ali cometidos de maneira fria, programada, calculada, sistemática, como política de Estado baseada no genocídio, com requintes de crueldade, merecendo adjetivos infernais por melhor representarem, no pensamento do mundo contemporâneo, a verdadeira e absoluta expressão do mal.

A Guerra das Guerras se deu entre os países do Eixo (Alemanha, Itália e Japão) e os Aliados, compostos pela maioria das nações que contribuíram de alguma forma no confronto. Com o fim da neutralidade soviética e com a intervenção estadunidense no conflito - o que somente ocorre em 1944 - os aliados vencem o Eixo, libertando os países dominados e pondo fim à Guerra que envolveu mais de 100 países através de 100 milhões de soldados, deixando, segundo apontam estimativas, de 50 a 70 milhões de mortos entre civis e militares, destes, aproximadamente até seis milhões de judeus.

A vitória total dos aliados decide o final da Guerra que apresenta um evento que não pode ser olvidado por ser de fundamental importância para o advento de um novo pacto global com o propósito de evitar as guerras. Dos países que compunham o Eixo, a Itália

\footnotetext{
${ }^{51}$ ARENDT, 1989, p. 23.

${ }^{52}$ Ibid., p. 24: “O antissemitismo alcançou o seu clímax quando os judeus haviam, de modo análogo, perdido as funções públicas e a influência, e quando nada lhes restava senão sua riqueza. Quando Hitler subiu ao poder, os bancos alemães, onde por mais de cem anos os judeus ocupavam posições- chave, já estavam quase judenrein — desjudaízados —, e os judeus na Alemanha, após longo e contínuo crescimento em posição social e em número, declinavam tão rapidamente que os estatísticos prediziam o seu desaparecimento em poucas décadas."
} 
havia passado ao lado dos aliados e a Alemanha rendida em 8 de maio de 1945 com a invasão de Berlim por tropas soviéticas. O Japão permanecia isolado.

Em 6 de agosto de 1945, os EUA lançaram o primeiro ataque nuclear da historia ao detonarem uma bomba nuclear em Hiroshima. Três dias depois, uma nova bomba é lançada em Nagasaki, levando o Império Japonês a se render em 15 de agosto de 1945. Ao todo, estimativas apontam para um numero aproximado de 220 mil mortos pelas duas bombas, numero que é somado pelas vitimas dos efeitos posteriores da radiação. Dentre estes, a maioria era civil.

Estes eventos encerram a Segunda Guerra mundial e, somados à destruição causada pelo confronto global, pelo numero de baixas humanas e pelas atrocidades cometidas pelo regime nazista, impôs ao mundo a necessidade de uma reorganização internacional e a construção de novos valores éticos-morais para a humanidade, como condição para a manutenção da sua existência na terra.

\subsection{A Organização das Nações Unidas e os direitos humanos: o novo e definitivo pacto global}

Diante o cenário surgido no pós-guerra, era certa a necessidade do mundo organizarse com o propósito de evitar que eventos semelhantes ocorridos recentemente se repetissem e, para tanto, era mister a criação de um ordenamento jurídico supranacional definitivo capaz de conter a autodestruição humana. Não se trataria, logo, de um mero tratado de paz, mas de um estabelecimento de mecanismos supranacionais de efetivação dela. Os tratados de paz, como explica Kant, por sua natureza temporária, servem apenas como interregno de novas guerras. O animus belicandi ainda está presente nesta interação entre Estados por não estarem eles submetidos a nenhuma lei. Entendia o filósofo que o agrupamento dos Estados livres e independentes equivale a um estado de guerra, em analogia a um povo que vive em um Estado sem leis. Propunha, destarte, um ambicioso projeto de reforma do modo de relação entre eles que levaria à ideia de um "super-Estadointernacional". Tal reforma, sob a égide de uma dinâmica processual, aponta a uma cidadania universal, regida pelos imperativos do Direito: de um Direito Civil de Estado em cada povo; de um Direito dos Povos ou Direito de Gentes para regular as relações entre Estados (base do atual Direito Internacional Público); e um Direito Cosmopolita de vocação mundial e que uniria a totalidade da espécie humana como cidadãos de um Estado Universal de homens. 
(...) toda a Constituição jurídica, no que diz respeito às pessoas que estão nela, é:

1. Uma Constituição segundo o direito político dos homens de um povo (ius civitatis); 2. Segundo o direito das gentes dos Estados em suas relações mútuas (ius gentium); 3. Uma Constituição segundo o direito cosmopolita, enquanto haja que considerar homens e Estados, em suas relações externas, como cidadãos de um estado universal da humanidade (ius cosmopoliticum). Esta divisão não é arbitrária, mas necessária no que tange à idéia da paz perpétua, pois se um destes Estados, em relação de influência física sobre os outros, estivesse em Estado Natural, implicaria o estado de guerra. Liberar-se dele é precisamente o nosso propósito. ${ }^{53}$

Com a sinalização de que o Eixo seria derrotado, os aliados começaram os preparativos para esta nova ordem internacional já em 1942, três anos, portanto, do fím da Segunda Guerra. Em outubro de 1943, por exemplo, a Conferencia de Moscou - reunindo EUA, Reino Unido e União Soviética - através de sua declaração final, afirma que "os aliados insistem na criação de uma organização internacional baseada no principio da igual soberania de todos os Estados pacíficos, pequenos ou grandes, com o objetivo de manter a paz e a segurança internacionais". Posteriormente, os EUA prepararam um texto contendo os principais dispositivos da futura organização internacional, durante a Conferencia de Dumbarton Oaks, de agosto a outubro de 1944.

Em tempo, os preparativos para essa nova ordem mundial também se desenvolviam na área econômica, portanto, concomitante ao pacto maior - a criação de uma super organização supra-estatal - também estavam em marcha preparativos para o desenho das relações internacionais no campo econômico, que resultou na Conferencia de Bretton Woods, em julho de $1944^{54}$, e desta, a criação do Fundo Monetário Internacional (FMI) e do Banco Mundial.

Finalmente, reunidos em São Francisco (EUA), 51 estados aprovaram a Carta das Nações Unidas, em 25 de junho de 1945, um mês após a rendição alemã ${ }^{55}$, criando, desse modo, a Organização das Nações Unidas. A vitória contra o eixo era iminente ${ }^{56}$ e tornavase imprescindível institucionalizar as relações internacionais diante os horrores cometidos pelo regime nazifascista e a destruição que o conflitou causou.

Cessadas as hostilidades, as consciências abriram-se, afinal, para o fato de que a sobrevivência da humanidade exigia a reorganização da vida em sociedade em escala planetária, com base no respeito absoluto à pessoa humana. No preâmbulo da Carta das Nações Unidas, os seus integrantes declaram-se "resolvidos a preservar as gerações vindouras do flagelo da guerra, (...) a reafirmar a fé nos direitos fundamentais do homem, na dignidade e no valor do ser humano, na

\footnotetext{
${ }^{53}$ KANT, Immanuel. Para a paz perpetua. Trad. Barbara Kristensen. Galícia: IGESIP, 2006, p. 66.

${ }^{54}$ Voltaremos ao tema no capitulo 4, subcapitulo 4.1 intitulado "O Principio da igualdade e as desigualdades". Cf p. 131

${ }_{55}$ Os alemães se renderam em 8 de maio de 1945.

${ }^{56}$ Os japoneses se renderam em 15 de agosto de 1945.
} 
igualdade de direitos dos homens e das mulheres, assim como das nações grandes e pequenas, e (...) a promover progresso social e melhores condições de vida dentro de uma liberdade mais ampla.,"57

Vale observar que, no momento de aprovação da Carta da ONU, a humanidade ainda não havia experimentado o poder de destruição das armas nucleares, o que ocorreria cerca de 2 meses depois. É normal associar essa nova arquitetura internacional somente às atrocidades cometidas pelo regime nazista durante a Segunda Guerra, uma vez que ela foi redigida sob o impacto causado por elas, omitindo, no entanto, tudo o que se refere à URSS e os vários abusos cometidos pelas potencias ocidentais. Sem embargo, a ONU dever ser entendida como resultado das atrocidades cometidas nesta e da somatória de todas as guerras, conflitos, massacres, genocídios, extermínios, perseguições, antissemitismos, etc., da historia. O domínio da tecnologia armamentista nuclear forçou a "humanidade" a se organizar juridicamente de maneira universal como condição para sua própria sobrevivência.

A criação da ONU submete os Estados à uma ordem internacional, alterando, ao menos no plano normativo, a ordem jurídica do mundo, levando-o do estado de natureza ao estado civil, materializando o pensado por Kant. Sua missão principal é buscar a paz entre as nações do planeta. Isto é, a ONU tem sua gênese na guerra (ou no temor a ela) e portanto, uma característica reativa. Trata-se de um intento de sustar o que muitos entendem como a natural característica humana de guerrear. Nas palavras do sueco Dag Hammarskjold - segundo a ocupar o cargo de Secretário Geral - a ONU "não foi criada para conduzir a humanidade ao paraíso, mas para evitar que ela tombasse no inferno" ${ }^{58}$.

A ONU é uma organização de vocação geral, de cooperação, independente (só atende ao direito internacional público) e universal (propõe-se a objetivos de cooperação entre todos os Estados). Ela representa um marco transformador na história do Direito Internacional Público e por conseguinte na história das sociedades contemporâneas. Tratase de um novo e definitivo pacto global destinado principalmente a estabelecer regras de relacionamento entre os Estados e entre os estes e os cidadãos que passam, a partir dela, a ser titulares de Direito Internacional, como cidadãos universais, confirmando a ideia de família humana.

Este novo concerto internacional estabelecido pela criação da ONU impôs uma mudança no entendimento sobre o instituto da soberania. Se inicialmente a soberania e o

\footnotetext{
${ }^{57}$ COMPARATO, 2010, p. 540.

${ }^{58}$ SEITENFUS, 2008, p. 127.
} 
principio da igualdade dos Estados permitiram que eles tratassem internacionalmente dando inicio ao processo que desencadeou no Direito Internacional contemporâneo, a idéia da soberania absoluta do Estado sempre foi obstáculo para o desenvolvimento da sociedade cosmopolita e trans-solidaria. O tema da soberania é um tanto abstrato e controverso. Mesmo à época dos tratados bilaterais da Paz de Vestefália, quando um Estado assina e ratifica um tratado, ele empresta parte da sua soberania, posto que admite normas de conduta exteriores dentro de seu território. Em contrapartida, por ser um tratado um acordo volitivo, um membro poderá renunciar a qualquer momento com base no principio da soberania, fazendo com que tais normas percam eficácia em seu território. Por estas razões, de certo modo, a soberania sempre foi relativa e absoluta ao mesmo tempo. Sem embargo, o incremento do Direito das Gentes, através da criação da ONU, não deixou duvidas sobre o fim da soberania absoluta e inicio da era da soberania compartilhada.

\begin{abstract}
A opção intelectual pelo primado do direito internacional sobre o interno, como se pode perceber, leva necessariamente a um abrandamento da noção tradicional da soberania. Com efeito, sob essa ótica, o Estado somente é soberano num sentido relativo, eis que não esta subordinado a nenhuma ordem jurídica superior, salvo a internacional. Já na hipótese contraria, ou seja, a da prevalência da ordem interna sobre a internacional, o Estado é soberano num sentido absoluto, na medida em que não está submetido a qualquer outro poder. ${ }^{59}$
\end{abstract}

A Carta da ONU dispõe em seu artigo $1^{\circ}$ o principio da igualdade de todos os seus membros diretamente vinculado à ideia da soberania. $\mathrm{O}$ fim da soberania absoluta é prevista no próprio preâmbulo quando apresenta a autoria da Carta, "Nós, os povos das Nações Unidas, resolvidos". Isto é, a Carta deve ser vista como um patrimônio dos povos e não dos Estados. Com a criação da ONU, o individuo adquire titularidade no Direito Internacional e é posto prioritariamente aos interesses estatais. Isto é, os indivíduos agora têm direitos protegidos internacionalmente frente ao poder do seu próprio Estado nacional.

Em verdade, o genocídio cometido pelo regime nazista contra o povo judeu levou os Estados a instituírem o Tribunal de Nuremberg (1945/1946) e a aprovarem a Convenção para Prevenção e Repressão ao Crime de Genocídio (1948). O Tribunal de Nuremberg inaugura na história a humanidade como titular de Direito Internacional, sendo esta titularidade ratificada e consolidada pela DUDH.

Essa ideia é reforçada pela afirmação da fé nos direitos fundamentais do homem, na dignidade e no valor do ser humano. A Carta dispõe também, em seu artigo $2^{\circ}$, inciso $7^{\circ}$, o limite desta soberania e a concretização do ordenamento internacional supra-estatal.

\footnotetext{
${ }^{59}$ LEWANDOVISK, 2004, p. 246.
} 
Nenhum dispositivo da presente Carta autorizará as Nações Unidas a intervirem em assuntos que dependam essencialmente da jurisdição de qualquer Estado ou obrigará os Membros a submeterem tais assuntos a uma solução, nos termos da presente Carta; este princípio, porém, não prejudicará a aplicação das medidas coercitivas constantes do Capítulo VII. ${ }^{60}$

Isto é, a soberania persiste, não resta dúvida, porém relativamente. Mesmo na hipótese de um Estado não aderir à Carta da ONU, desejando manter-se isolado da sociedade internacional, alheio ao ordenamento jurídico, sua soberania não será absoluta. Neste caso, se as ações deste Estado alienado forem contrarias aos princípios desta sociedade internacional, autorizará, segundo suas regras, o império da força contra ele. Esta característica universal impositiva enterra a soberania absoluta que só retornaria com uma eventual dissolução da ONU.

Para iniciar esta nova ordem, estruturalmente, foram criados a Assembleia Geral (órgão deliberativo máximo da ONU), o Conselho de Segurança e o Conselho Econômico Social (ECOSOC) e incorporados outros órgãos sob seus auspícios como forma de centralizar os esforços nesta direção. Neste sentido, a ONU absorveu a OIT, associou o FMI e o Banco Mundial e criou outros órgãos - conhecidos como agencias especializadas como a FAO, a OMS a UNESCO.

Dentre as atribuições do ECOSOC encontra-se toda a agenda de direitos humanos, a cargo, até 2006, da Comissão de Direitos Humanos, órgão subsidiado a ele ${ }^{61}$. Por sua vez, o Conselho de Segurança é o responsável pelo papel coercitivo do Direito Internacional contemporâneo. Segundo aponta Bobbio, o que difere o ordenamento normativo do Direito de outras formas de ordenamentos normativos, consiste no fato de que o Direito recorre, em ultima instancia, à força física para obter o respeito das normas ${ }^{62}$.

Pois, recordemos a principal crítica sobre a iniciativa da Liga das Nações porquanto por muitos momentos se tratava mais de um tribunal permanente a sancionar a derrotada Alemanha. O objetivo para a nova tentativa da ordem internacional era não repetir os erros cometidos pela Liga das Nações ao final da Primeira Guerra, que, contrariamente ao seu propósito - o de evitar guerras - permitiu que a humanidade testemunhasse o maior conflito da sua história. Sendo assim, a ONU não poderia desempenhar um papel de "sindicato dos

\footnotetext{
${ }^{60}$ O capitulo VII da Carta da ONU trata do Conselho de Segurança,

${ }^{61}$ Trataremos da extinção da Comissão dos Direitos Humanos e criação do Conselho de Direitos Humanos no subcapitulo 2.1 "Do Conselho dos Direitos Humanos", Cf. p. 70.

${ }^{62}$ BOBBIO, N.; MATTEUCCI, N.; PASQUINO, G.. Dicionário de politica I. Trad., Carmen C. Varriale et ai. Coord. Trad. Joao Ferreira e Luis Guerreiro Pinto Cacais. $11^{\text {a }}$ Ed. Brasília: UNB, 1998. p. 349.
} 
vencedores da guerra", mas efetivamente uma organização a serviço da humanidade ${ }^{63}$.

Contudo, como de costume, os vitoriosos em uma guerra determinam a nova ordem. Desse modo, o Conselho de Segurança é composto por cinco membros permanentes, sendo eles: China, França, Rússia, Reino Unido e $\operatorname{EUA}^{64}$ e dez membros rotativos ${ }^{65}$. Cada membro tem direito a um voto e, para a aprovação de decisões procedimentais, é necessária maioria dos votos na relação nove em quinze, consoante o principio da busca pelo consenso. Para decisões sobre ações substantivas a serem tomadas - intervenções militares, por exemplo -, além dos nove votos dos quinze, todos os membros permanentes devem votar a favor. É dizer que os membros permanentes têm status privilegiado em relação aos outros uma vez que detém o poder de veto. Esta característica, entre outras, atenta contra o principio da igualdade dos Estados soberanos, não autorizando a $\mathrm{ONU}$ proclamar-se inteiramente democrática.

A Segunda Guerra, além de todos os efeitos já mencionados, também ratificou uma tendência na nova ordem mundial. As grandes potencias vitoriosas nesta guerra foram principalmente URSS e EUA, cujas matrizes politico-ideológicas eram antagônicas. O socialismo adotado pela URSS como regime político revolucionário era encarado pelos EUA como o grande inimigo de seu sistema político vigente e o choque se daria naturalmente dado os anseios imperialistas das duas partes. O fim da Guerra dividiu o mundo em dois, bi-polarizando-o entre o "bloco capitalista", liderado pelos EUA e o "bloco comunista", pela URSS, inaugurando a era conhecida como Guerra Fria.

Restava a certeza que uma guerra franca entre as duas potencias nucleares seria suficiente para sepultar a humanidade. A Guerra Fria, entretanto, desenrolou-se nos bastidores através dos jogos de influência. Pressões de ambas as partes em converter ou manter Estados sob o regime politico-ideológico pretendido, desencadearam conflitos, sem que, todavia, houvesse confronto direto declarado entre as duas potencias. É o caso, por exemplo, da Guerra da Coreia (de 1950 à 1953) devido a divisão territorial em Coreia do Sul - apoiada pelos EUA - e Coreia do Norte - apoiada pela China e URSS. Da Guerra do Vietnã (de 1955 até 1975) cujos combates estenderam-se também nos vizinhos Laos e Camboja, protagonizada, de um lado, pelo Vietnã do Norte - aliado da URSS - e de outro,

\footnotetext{
${ }^{63}$ SEITENFUS, 2008, p. 121.

${ }^{64}$ Estes são os protagonistas entre os aliados que venceram a Segunda Guerra.

${ }^{65}$ Os assentos rotativos do Conselho de Segurança atualmente são ocupados por Bósnia e Herzegovina, Brasil, Colômbia, Gabão, Alemanha, Índia, Líbano, Nigéria, Portugal e África do Sul.
} 
pelo o Vietnã do Sul - com o apoio dos EUA. Esta guerra é lembrada até hoje como a maior derrota sofrida pelos EUA militar e moralmente. A Guerra Fria foi igualmente responsável pelo estabelecimento de ditaduras militares na América Latina - para combater a "ameaça comunista" -, a revolução cubana e o embargo dos EUA à Cuba, a divisão da Alemanha em duas, as anexações de republicas vizinhas pela URSS, etc., mas sobretudo, pela corrida armamentista em escala mundial, incluindo a produção de armamento nuclear.

De fato, as armas nucleares são as mais letais armas jamais desenvolvidas, capazes de destruir uma cidade inteira, matar milhões de pessoas e destruir o meio ambiente, afetando as gerações futuras devido a seus efeitos catastróficos de longa duração. Até hoje na historia das guerras, armamentos nucleares somente foram utilizados nos eventos em Hiroshima e Nagasaki. Porém, segundo a agencia da ONU especializada no desarmamento UNODA (United Nations Office for Disarmament Affairs), estima-se que, atualmente, o arsenal nuclear mundial gira em torno de 26 mil bombas deste tipo suficientes para destruir o planeta dezenas de vezes. A existência de tais armas é por si só uma ameaça à paz na terra, figurando, desde o inicio da ONU, o desarmamento, como um de seus objetivos principais $^{66}$. A eliminação das armas nucleares desenvolve-se através de tratados, bilaterais ou multilaterais, como seu principal instrumento. Dentre eles o mais importante é o Tratado sobre a Não-Proliferação de Armas Nucleares ${ }^{67}$. Contudo, apesar do objetivo da comunidade internacional de eliminar as armas nucleares preencherem a agenda da ONU desde 1945 somente em 1982 uma agência foi criada com este propósito. Após alterações em 1992 e 1998, a Assembleia Geral estabeleceu a UNODA, enfim, em 2007. Atualmente contam com armamento nuclear EUA, Rússia, Reino Unido, França, China ${ }^{68}$, Índia, Paquistão, Israel ${ }^{69} \mathrm{e}$, supostamente, Coreia do Norte ${ }^{70}$. Além destes, os EUA garante o uso

\footnotetext{
66 "The first resolution adopted by the UN General Assembly in 1946 established a Commission to deal with problems related to the discovery of atomic energy among others. The Commission was to make proposals for, inter alia, the control of atomic energy to the extent necessary to ensure its use only for peaceful purposes. The resolution also decided that the Commission should make proposals for "the elimination from national armaments of atomic weapons and of all other major weapons adaptable to mass destruction." Sitio da internet da UNODA (United Nations Office for Disarmament Affairs). ” Disponível em

http://www.un.org/disarmament/WMD/Nuclear/. Acessado em 01.10.2011.

${ }^{67}$ A este soma-se o Tratado banindo testes nucleares na atmosfera, ao ar livre ou marítimos (Treaty Banning Nuclear Weapon Tests In The Atmosphere, In Outer Space And Under Water) e o Tratado Geral sobre o Banimento de Testes Nucleares (Comprehensive Nuclear-Test-Ban Treaty).

${ }^{68}$ Estes cinco primeiros são Estados-membros do Tratado sobre a Não-Proliferação de Armas Nucleares como também são os 5 membros permanentes do Conselho de Segurança.

${ }^{69}$ Israel não é signatário do tratado e a sua condição em relação às armas nucleares é incerta. Porém especialistas apontam que o arsenal bélico israelense contém armas nucleares.

${ }^{70}$ Suspeita-se que a Coreia do Norte tenha desenvolvido sua primeira bomba nuclear porém até o momento os fatos não foram comprovados pela não-colaboração do regime de Pyongyang.
} 
de armas nucleares, através de dispositivos no Tratado da Organização do Atlântico Norte (OTAN), por Bélgica, Alemanha, Itália, Holanda e Turquia.

Não obstante, a despeito do pouco resultado no tocante às armas nucleares, a ONU desenvolveu-se estando hoje presente em mais de 192 países em missões quer humanitárias, quer de segurança, quer de cooperação para o desenvolvimento. Trata-se de um complexo e burocrático organismo, essencial em situações especiais como catástrofes naturais, conflitos armados, epidemias, ou na cooperação técnica internacional, sendo o principal ator do Direito Internacional Publico.

No campo econômico social, a ONU, através do ECOSOC, teve seus esforços beneficiados pelo período chamado de "trinta anos gloriosos", "em que a humanidade conheceu uma taxa media de crescimento econômico e uma queda nos índices de desemprego sem precedentes no curso da historia" ${ }^{71}$. Este cenário inicial da ONU começa a sofrer profundas mudanças a partir dos anos sessenta.

Com a independência das antigas colônias ${ }^{72}$ - principalmente francesas e inglesas, mas também belgas, italianas, holandesas - mais de uma centena de países, agora livres, juntaram-se a ONU, alterando seu quadro, e influenciando diretamente no seu modus operandi e processos decisórios. Nos anos iniciais, esse processo de independência trouxe crescimento econômico para as ex-colônias o que não pôde ser observado em seguida.

É nos anos setenta que o mundo mergulha em um processo de deterioração econômica "como assinalou o Relatório Mundial sobre o Desenvolvimento Humanos de 1999, das Nações Unidas, a humanidade em seu conjunto vem sendo submetida a um processo fortemente contraditório de unificação técnica e desagregação social” ${ }^{, 73}$. O capitalismo demonstra sua face mais cruel: a enorme geração de riquezas resta concentrada na mão de uma oligarquia politico-empresarial impondo aos menos privilegiados especialmente nos países considerados “em vias de desenvolvimento", níveis de pobreza que sugerem os tempos medievais. Essa fase iniciada nos anos setenta dura até hoje, alimentando a desigualdade entre os indivíduos a despeito de toda a construção e reafirmação do principio da igualdade ao longo da história.

Em 1960, a quinta parte mais rica da população mundial dispunha de uma renda media 30 vezes superior à dos $20 \%$ mais pobres. Em 1997, essa proporção havia mais do que dobrado: 74 a 1 . No inicio do século XXI, ela passou a ser de 80

\footnotetext{
${ }^{71}$ COMPARATO, 2010. p. 540.

${ }^{72}$ Cf. in Declaração das Nações Unidas sobre a concessão da Independência dos Países e Povos Colonizados (1960), disponível em http://www.comitepaz.org.br/Durban_1.htm

${ }^{73}$ Ibid., 2010, p. 541.
} 
para $1 .^{74}$

$\mathrm{Na}$ década de 80 , outro evento importante influencia fundamentalmente a história da ONU: o fim da Guerra Fria. Diversas razões internas e externas enfraqueceram a extinta URSS e seu campo de influência, dentre eles a corrida armamentista e espacial com os EUA que demandava pesados investimentos. A queda do Muro de Berlin, em 1989, é representativa deste movimento de mudança, que, apesar dos esforços empregados pelo último líder soviético Mikhail Gorbachev em estabelecer um regime mais livre através da perestroika e glasnost ${ }^{75}$, colapsa a URSS, restando em seu lugar a Federação Russa e mais países que, independentes politicamente, ocuparam cadeiras como membros da ONU. A falência do Estado soviético decreta o fim da Guerra Fria que embarricava o avanço do Direito Internacional devido às ideologias incompatíveis das duas potencias que comumente se apresentavam nos processos decisórios da ONU. A este exemplo

(...) a rodada Uruguai de negociações comerciais multilaterais, iniciada em 1986
e terminada em dezembro de 1993, talvez tivesse apenas ampliado o número de
acordos abrangidos pelo GAT, mas dificilmente conseguiria criar a
Organização Mundial do Comércio, como ocorreu, concluída que foi já na era
"pós-Muro de Berlim."76

Entretanto, a bipolaridade a qual o mundo estava submetido, apesar de dificultar a convergência diplomática, decretava certo equilíbrio no mundo. Com o fim da URSS, os EUA despontam como a única grande potencia politico-econômico-militar, livre para interagir, ou policiar o mundo. Os EUA é, a um só tempo, o maior financiador da ONU e seu maior sabotador. Sua atuação influencia diretamente a credibilidade da ONU que, por sua vez, é avaliada pelo seu desempenho - questionado, criticado ou elogiado diretamente ao que acontece no terreno. Muito de sua credibilidade foi abalada, por exemplo, nos episódios da intervenção na antiga Iugoslávia - devido à demora do Conselho de Segurança em intervir - mas, sobretudo, à invasão do Iraque pelos EUA em 2003, contrariando as determinações do Conselho de Segurança. Outro exemplo da atuação prejudicial dos EUA na ordem internacional é o não reconhecimento da competência do Tribunal Penal Internacional, do Sistema Interamericano de Direitos Humanos, como a não assinatura e ratificação da vasta maioria dos instrumentos internacionais de direitos humanos. Neste sentido:

O acesso dos Estados Unidos á condição de potencia hegemônica mundial, após o esfacelamento da União Soviética, constitui séria ameaça à reorganização das

\footnotetext{
${ }^{74}$ COMPARATO, 2010, p. 541.

${ }_{75}$ Perestroika significa restruturação enquanto Glasnost, transparência (no sentido de publicidade).

${ }^{76}$ CRETELLA NETO, 2007, p. XXX - prólogo.
} 
relações internacionais num sentido comunitário. O último tratado internacional de direitos humanos integralmente ratificado pelos Estados Unidos foi o Pacto aprovado pelas Nações Unidas em 1966, sobre os direitos civis e políticos. O pacto gêmeo sobre os direitos econômicos, sociais e culturais teve sua ratificação rejeitada pelo Congresso norte-americano. A partir de então, os Estados Unidos vêm-se recusando, sistematicamente, a se submeter ás normas internacionais de proteção dos direitos humanos, por considerarem que isto implica uma limitação de sua soberania. ${ }^{77}$

Dessa maneira, ao que parece, os EUA entendem ser absolutamente soberanos, revivendo o tempo anterior à Paz de Vestefália por não se submeter ao Direito Internacional. Na prática, os EUA vão-se tornando assim, definitivamente, um Estado fora da lei no plano internacional. ${ }^{78}$

Tal ideia é corroborada, ainda, pela posição estadunidense, em novembro de 2011, em relação ao reconhecimento e aceitação do Estado da Palestina como membro da UNESCO, que declarou suspender seu aporte financeiro destinado para esta agência. Isso poderia não impactar o trabalho desenvolvido pela UNESCO se não fosse os EUA responsáveis por $24 \%$ de sua receita.

Apesar disto, a ONU completará em breve setenta anos como principal ator do Direito Internacional Público. Dentre suas atribuições, a competência para legislar internacionalmente é de fundamental importância para esta obra, uma vez que foi essa característica que permitiu o estabelecimento do DIDH, decretando o fim do Estatismo que considera o Estado como a única fonte de Direito competente para legislar.

\subsection{As normativas internacionais de direitos humanos}

Como vimos, a ONU é necessária para regulamentar as ações dos Estados entre si e entre Estados e indivíduos. A titularidade de indivíduos no Direito Internacional surgiu com os Tribunais de Nuremberg e a Carta das Nações Unidas, porém se materializa com a instrumentação internacional dos direitos humanos através de uma série de tratados multilaterais que definem o novo paradigma politico-ético-moral da sociedade internacional. Tais tratados vem se desenvolvendo ao longo da historia da ONU e alcançam seu momento de maior atividade nas ultimas quatro décadas, sendo ainda um movimento em expansão, característica primaria dos direitos humanos. Dada a competência para legislar, a ONU desenvolveu extensa normatização internacional sobre os direitos humanos até os dias atuais. $\mathrm{O}$ instrumento pioneiro desta nova arquitetura legal

\footnotetext{
${ }_{77}^{77}$ COMPARATO, 2010, p. 543.

${ }^{78}$ Ibid. p. 544.
} 
é, como sabemos, a DUDH que, ainda hoje, é o instrumento mais difundido dos direitos humanos que coroa esta nova fase da historia.

Contemporânea à Declaração, outros tratados importantes foram celebrados à época. Além do genocídio ${ }^{79}$, outros temas eram objeto de tratados, como o refugio ${ }^{80}$, o tráfíco de pessoas para o lenocínio ${ }^{81}$ e a discriminação no campo laboral ${ }^{82}$.

De 1948 a 1966, em termos de ampliação do rol de tratados e convenções de direitos humanos internacionais, não se notou grande atividade, em que pese o número de seminários, simpósios, encontros de lideres, etc., em especial, e as Convenções de Genebra.

Já em 1966, após a celebração dos Pactos Internacionais sobre Direitos Civis e Políticos e sobre Direitos Econômicos, Sociais e Culturais, nota-se um crescente no "legislar" em matéria de direitos humanos na ONU. Em 1968, a Assembleia Geral da ONU decide organizar uma conferencia, em Teerã, sobre a situação dos direitos humanos no mundo, o que se repetiria em 1993, em Viena. Outras tantas conferencias mundiais sobre temas específicos são organizadas pela ONU, a este exemplo: a Conferencia do Rio de Janeiro sobre o meio ambiente (1992); a de Copenhagen sobre as condições sociais (1980); a de Beijing sobre os direitos da mulher (1995) e a de Istambul sobre a Habitação (1996).

A partir dos Pactos, iniciou-se o período de grande efervescência na adoção de tratados em direitos humanos. Até o momento, são nove tratados internacionais de direitos humanos sobre temas que variam desde a discriminação contra a mulher ${ }^{83}$, discriminação racial $^{84}$, direitos da criança ${ }^{85}$, trabalhadores migrantes ${ }^{86}$, povos indígenas e tribais e diversidade biológica ${ }^{87}$, tráfico de pessoas ${ }^{88}$ até pessoas com deficiência ${ }^{89}$. Soma-se a estes

\footnotetext{
${ }^{79}$ Convenção para a Prevenção e Sanção do Crime de Genocídio, de 1948.

${ }^{80}$ Convenção sobre o Estatuto dos Refugiados, de 1951.

${ }^{81}$ Convenção para a Supressão do Tráfico de Pessoas e contra a Exploração da Prostituição Alheia, de 1949.

${ }^{82}$ Convenção sobre a Discriminação no Emprego e na Ocupação, de 1951 ( No 111), da OIT.

${ }^{83}$ Convenção sobre a Eliminação de todas as Formas de Discriminação contra a Mulher, de 1979, visando alcançar ratificação universal dentro de cinco anos, e seu Protocolo Facultativo, de 1999.

${ }^{84}$ Convenção sobre a Eliminação de todas as Formas de Discriminação Racial, de 1966.

${ }^{85}$ Convenção sobre os Direitos da Criança, de 1989 e seus dois Protocolos Facultativos, do ano 2000, e a Convenção da Organização Internacional do Trabalho sobre a Idade Mínima, de $1973\left(\mathrm{~N}^{\circ} 138\right)$ e a Convenção sobre as Piores Formas de Trabalho Infantil, de 1999 (No 182).

${ }^{86}$ Convenção sobre Trabalhadores Migrantes (Disposições Suplementares), de 1975 ( $\mathrm{N}^{\circ} 143$ ), da OIT e Convenção Internacional sobre a Proteção dos Direitos de todos os Trabalhadores Migrantes e de suas Famílias, de 1990.

${ }^{87}$ Convenção sobre Povos Indígenas e Tribais, de 1989 (Nº 169), da OIT e a Convenção sobre a Diversidade Biológica, de 1992.

${ }^{88}$ Convenção das Nações Unidas contra o Crime Transnacional Organizado, o Protocolo para Prevenir, Suprimir e Punir o Tráfico de Pessoas, especialmente Mulheres e Crianças, suplementando a Convenção e o Protocolo contra o Tráfico de Migrantes por Terra, Mar e Ar, suplementando a Convenção do ano 2000.
} 
extensa lista de convenções, acordos, resoluções, recomendações, etc., tratando de temas ligados, direta ou indiretamente, aos diretos humanos - incluindo-se a instrumentalização dos direitos humanos que também acontece em nível regional na Europa, América e África ${ }^{90}$ - através de uma serie de tratados. É a busca constante para aperfeiçoar os mecanismos de promoção e proteção dos direitos humanos previstos originariamente na DUDH que definem a inexorável relação entre os direitos humanos e a ONU, sendo esta a criadora daqueles, que por sua vez, é propósito desta.

\subsubsection{A Declaração Universal dos Direitos Humanos}

Em atenção ao artigo 55 da Carta da ONU, em 1946, o ECOSOC - através da extinta Comissão de Direitos Humanos - prepara a DUDH, que é aprovada pela Assembleia Geral da ONU, em 10 de dezembro de 1948, em Paris, através da resolução 217 A III. A Declaração tinha com o intuito elencar os direitos a que a Carta da ONU se referia três anos atrás como os "direitos do homem" que devem ser assegurados a cada ser humano do planeta, indispensáveis para criar condições de estabilidade e bem-estar necessárias às relações pacíficas e amistosas entre as $\mathrm{Nações}^{91}$.

A DUDH é considerada o produto elogiável do trabalho desempenhado pelos seus redatores. Participaram da elaboração da DUDH o francês René Cassin, o canadense John Humphrey, o libanês Charles Malik e o Chinês P. C. Chang, sob a presidência de Eleanor Roosevelt - viúva do ex-presidente americano Franklin Roosevelt ${ }^{92}$. De fato, congruir varios posicionamentos distintos no tocante à religião, filosofias, políticas, etc., em um documento de tamanha importância, exigiu árduo empenho nas negociações diplomáticas.

O resultado é tanto mais admirável porquanto nos trabalhos preparatórios da Declaração colidiam as visões jus naturalistas e positivistas, religiosas e laicas, liberais e marxistas dos direitos humanos, tendo por pano de fundo a emergência da Guerra Fria. ${ }^{93}$

A DUDH protege, em seus trinta artigos, os direitos humanos amplamente, estabelecendo um extenso rol de direitos indispensáveis para satisfazer integralmente o desenvolvimento da personalidade física, moral e intelectual dos indivíduos. Estão previstos nela, de maneira genérica, os direitos civis e políticos (art. 1 a 22) e os direitos

\footnotetext{
${ }^{89}$ Convenção sobre os Direitos das Pessoas com Deficiência, de 2006.

${ }^{90}$ A Ásia ainda não conta com um sistema regional de proteção dos direitos humanos.

${ }^{91}$ Preâmbulo da Declaração Universal dos Direitos Humanos.

${ }^{92}$ ALVES, José Augusto Lindgren. A Arquitetura internacional dos direitos humanos. São Paulo: FTD, 1997, p. 26.

93 Ibid., p. 27.
} 
econômicos, sociais e culturais (art. 23 a 27).

Além de elencar os direitos humanos, a Declaração ratifica o entendimento sobre os princípios inerentes a eles. Já em seu preâmbulo, ratifica os princípios trazidos pela Carta da ONU proclamando novamente a "fé nos direitos fundamentais do homem, na dignidade e no valor da pessoa humana, na igualdade de direitos dos homens e das mulheres e declararam-se resolvidos a favorecer o progresso social e a instaurar melhores condições de vida dentro de uma liberdade mais ampla." ${ }^{94}$ Estes princípios são valores inerentes a cada individuo constituindo pressupostos para a satisfação dos seus direitos subjetivos. Por outro lado, a DUDH também insere outros princípios importantes para os direitos humanos, vale dizer: inalienabilidade; indivisibilidade e universalidade. Estes princípios são valores que devem ser observados não como pressupostos para a satisfação dos direitos humanos, mas como qualidade dos próprios direitos humanos. Isto é, através da observância dos princípios da dignidade, igualdade e liberdade, alcançam-se os direitos humanos que são, por sua vez: (i) inalienáveis - porquanto não se pode perde-los -; (ii) indivisíveis - são interdependentes por ser um conjunto a ser considerado em sua integralidade e (iii) universais - por valerem para todo e qualquer ser humano do planeta. Esse conjunto de direitos, observados seus princípios, são entendidos essenciais "para que o homem não seja compelido, em supremo recurso, à revolta contra a tirania e a opressão", o que é uma ameaça à paz duradoura.

A universalização dos direitos humanos permitiu a formação de um sistema normativo internacional de proteção, que passou a produzir inúmeros instrumentos em âmbito global e regional, de caráter geral ou especifico, consolidando uma efetiva garantia de salvaguarda de direitos que devem ser observados em âmbito universal. A DUDH tem como objetivo consolidar uma "ética universal" na medida em que consagra um consenso sobre valores de cunho universal a serem seguidos pelos Estados. Ela é frequentemente identificada como um denominador comum de um mínimo existencial para a satisfação do bem-estar do ser humano. Porém, por serem os direitos contidos nela um ideal a ser alcançado para a maioria da população mundial, entendemos que ela cumpre mais o papel de uma referencia de tais direitos a orientar as medidas de aplicação e efetivação deles. Por este motivo os direitos são elencados de maneira genérica como um objetivo a ser alcançado em escala mundial. Ademais, a DUDH é laica porquanto evita fundamentar

\footnotetext{
${ }^{94}$ Preâmbulo da Declaração Universal dos Direitos Humanos. (grifo nosso)
} 
estes direitos do ponto de vista religioso ou filosófico, atribuindo-os tão somente à dignidade inerente a todos os membros da família humana ${ }^{95}$, estratégia necessária para não justificar argumentos de imposição cultural e religiosa.

Frequentemente, tenta-se, ou tentou-se, retirar a importância da DUDH pelo fato de não possuir ela força vinculante em relação aos Estados. De fato, a DUDH é uma declaração adotada por resolução da ONU. Não se trata de um tratado com mecanismos jurídicos previstos para seu cumprimento. Sua função é a de declarar direitos, estabelecendo o novo paradigma ético-moral. Ledo engano pensar que ela é só um documento simbólico da boa vontade humana.

A DUDH é um verdadeiro marco histórico da sociedade humana. Apesar de não ser um instrumento legal, sua importância não é somente simbólica posto vez que seus valores direcionam políticas em âmbito mundial, sendo evocadas pelos tribunais regionais e nacionais, influenciando, direta ou indiretamente, os ordenamentos jurídicos domésticos, principalmente as Constituições contemporâneas.

Assim sendo, a DUDH é o referencial moral em relação aos indivíduos nesta orquestração internacional estabelecida pela Carta da ONU que cumpre o objetivo de consagrar o novo paradigma-ético-universal ao afirmar um consenso sobre valores universais a serem seguidos pelos Estados. É o inicio da era dos direitos humanos.

\subsubsection{Os Pactos Internacionais de 1966}

Em 1966, aproximando-se dos vinte anos da DUDH, a extinta Comissão de Direitos Humanos propõe a criação de um tratado com mecanismos jurídicos que forcem a adoção dos direitos contidos nela. Este novo instrumento internacional representa o passo seguinte da DUDH no avanço dos direitos humanos. Como vimos, apesar de tudo, a DUDH não tem força vinculante. Atenta a este fato, a Comissão de Direitos Humanos empenhou esforços para a produção de novos instrumentos internacionais, estes, com força vinculante, para garantir a efetivação dos direitos definidos na DUDH.

Estes instrumentos encampariam todos os direitos humanos previstos na DUDH, ou seja, os direitos humanos civis, políticos (primeira geração) e os econômicos, sociais e culturais (segunda geração). A missão era nada simples.

Os direitos de primeira geração tem esse entendimento por serem os direitos civis e

\footnotetext{
${ }^{95}$ ALVES, 1997, p. 26.
} 
políticos os primeiros a aparecerem em ordenamentos jurídicos, principalmente na Declaração de Independência dos EUA e na Declaração dos Direitos do Homem e do Cidadão - resultado da Revolução Francesa -, ambos do final do século XVIII. Já os direitos de segunda geração somente viriam a surgir em ordenamentos jurídicos no inicio do século XX, consoante o visto anteriormente.

À época da decisão pela elaboração deste instrumento - inicio da década de sessenta o mundo vivia o auge da Guerra Fria - a Guerra do Vietnam, por exemplo, estava em andamento somente chegando ao fim em 1975 - o que dificultava o entendimento diplomático entre os países do bloco capitalista e o bloco socialista.

Pois bem, os direitos de primeira geração são de cunho liberal, mais afeitos à política capitalista. Os direitos civis e políticos são essenciais para o estabelecimento de democracias que fluem através da liberdade, inclusive a de empreender. Por seu turno, os direitos de segunda geração representam uma bandeira de cunho mais socialista por tratarem principalmente dos direitos econômicos e sociais. Isto é, direitos que agradavam a uma corrente desagradavam a outra e vice-versa. Diante o impasse, as negociações no âmbito da Comissão de Direitos Humanos levaram à feitura de dois instrumentos independentes. Desta forma, em 1966, dois Pactos e 1 protocolo facultativo foram adotados em San Jose, na Costa Rica: um a tratar dos direitos civis e políticos (PIDCP) e o outro dos direitos, econômicos sociais e culturais (PIDESC). O referido protocolo refere-se aquele e autoriza o recebimento de denuncias dos indivíduos contra os Estados signatários. É o exemplo claro da titularidade dos indivíduos como sujeito ativo do Direito Internacional.

A justificativa encontrada para a separação da salvaguarda destes direitos em dois instrumentos foi a aplicação deles. Enquanto os direitos civis e políticos tem aplicação imediata por dependerem exclusivamente da ação positiva ou negativa do Estado - por força de uma lei (em tese) é possível estabelecer uma democracia "materialmente" com os direitos civis e políticos respeitados da noite para o dia), os direitos econômicos, sociais e culturais são entendidos como direitos de aplicação progressiva não podendo, nem o mais sonhador dos missionários dos direitos humanos, desejar sua satisfação da noite para o dia, por depender, a satisfação deles, dos recursos financeiros e ações de médio e longo prazo.

Portanto, são, estes direitos, progressivamente realizáveis. Nesta esteira:

Diferentemente, porém, do que se passa com os direitos civis e políticos, cuja implementação se torna obrigação imediata, sem condicionantes, para os Estados-partes, em favor de todos os indivíduos que se encontrem em sua 
jurisdição, pelo Pacto Sobre Direitos Econômicos Sociais e Culturais, os Estados que o ratificam assumem o compromisso de assegurar progressivamente "até o máximo dos recursos disponíveis (...)".96

O PIDCP amplia, aprofunda e esclarece os direitos civis e políticos já previstos na DUDH. Porém, não se trata de uma simples reafirmação de direitos declarados mas de um compromisso formal que assumem os Estados-partes de respeita-los e garanti-los "por meio de medidas legislativas ou de outra natureza, assegurando recursos compensatórios efetivos às pessoas que tenham tido seus direitos violados, ainda que as violações decorram de atos praticados por pessoas investidas de funções oficiais". ${ }^{97} \mathrm{O}$ Estado-parte do PIDCP assume a competência do Comitê de Direitos Humanos, que é o Órgão de Tratado criado pela Assembleia Geral para monitorar o cumprimento das obrigações afirmadas nele pelos Estados-membros. Este monitoramento ocorre através da submissão de relatórios regulares ao Comitê sobre como os direitos estão sendo implementados. Recebidos estes relatórios, o Comitê exaure um documento (Concluding Observations) com recomendações aos Estados. Além disso, o Comitê também é competente para analisar denuncias entre Estados, isto é, um Estado-parte pode denunciar outro perante o Comitê de Direitos Humanos por força do artigo 41 do PIDCP. O protocolo facultativo a que nos referimos anteriormente admite a possibilidade de o Comitê receber denuncias de indivíduos. Em 1989, um segundo protocolo opcional a este Pacto foi lançado. O Protocolo opcional $\mathrm{n}^{\mathrm{o}} 2$ proíbe a pena de morte nos Estados-membros.

O PIDCP teve ampla adesão contando hoje com 167 Estados-partes. Dos que não fazem parte deste Tratado, incluem-se Cuba, China, Malásia, entre outros. O protocolo facultativo $\mathrm{n}^{0} 1$ conta com 114 Estados-membros e o segundo com 73. A ausência mais importante deste ultima, é, sem duvida, a estadunidense.

Por seu turno, o PIDESC tem atualmente 160 Estados-membros, não figurando entre eles os EUA, naturalmente. O PIDESC tem também um protocolo facultativo lançado em 2008 que trata sobre a competência do respectivo órgão de tratado para este Pacto - Comitê dos Direitos Econômicos Sociais e Culturais - em receber denuncias de indivíduos ou grupos alegando violações de qualquer direito econômico, social e cultural previsto no Pacto. Até o presente momento, apenas cinco países ratificaram o protocolo facultativo: Argentina, Equador, El Salvador, Mongólia e Espanha.

Além de ter força vinculante - gerando obrigações para os Estados signatários - os

\footnotetext{
${ }^{96}$ ALVES, 1997, p. 44.

${ }^{97}$ Ibid., p. 35.
} 
dois pactos constituem uma codificação detalhada dos direitos humanos, aprofundando-os em relação à DUDH. Através das Observações Gerais, os órgãos de tratado interpretam o conteúdo dos Pactos, aprofundando o entendimento sobre estes direitos. Estes órgãos determinaram o modus operandi da ONU em relação aos direitos humanos especificamente. Com o surgimento de outros tratados de direitos humanos posteriores aos Pactos, respectivos órgãos de tratados são criados com o propósito de monitorar a implementação dos direitos objeto deles, conformando o atual mecanismo de promoção e proteção dos direitos humanos.

\subsubsection{As Conferencias de Direitos Humanos: Teerã e Viena}

Os Pactos, embora adotados em 1966, somente entraram em vigor em 1976 devido a dispositos contidos nos próprios. A redação é comum para os artigos 49 do PIDCP e 27 do PIDESC e dispõe que os pactos somente entram em vigor três meses após o depósito do instrumento de ratificação do trigésimo-quinto Estado-parte a se comprometer com ele, o que somente veio a ocorrer em 1976 para ambos. Em verdade, ocorreu em outubro de 1975 e o fato de terem os dois entrado em vigor no mesmo período dá-se, essencialmente, pela adesão do Reino Unido aos dois instrumentos, trazendo com ele boa parte dos países do commonwealth. Estes depósitos aguardaram até 1976 para que fossem feitos os procedimentos para oficializar a entrada em vigor dos referidos Pactos.

A elaboração dos Pactos era uma das atividades do ONU à época para positivar os direitos humanos, mas não a única. Como afirmamos, neste momento tem inicio o período da efervescência da produção normativa dos direitos humanos que avança progressivamente até os dias atuais. A elaboração dos Pactos acompanha, entre outros eventos, a elaboração da Convenção Internacional sobre a Eliminação de Todas as Formas de Discriminação Racial, de março de 1966.

Em 20 de dezembro de 1965, a Comissão de Direitos Humanos, atendendo a um pedido da Assembleia Geral, adota a resolução 2081 (XX) pela qual decide que um comitê preparatório formado por 17 Estados-membros será estabelecido para a realização de uma Conferência Internacional sobre os Direitos Humanos - a ser realizada no ano de 1968 com o propósito de (i) avançar na promoção dos princípios e dos direitos civis, políticos, econômicos, sociais e culturais contidos na DUDH e (ii) combater a discriminação ou negação de direitos com base na raça, cor, sexo, língua ou religião, em particular para permitir a abolição do regime do apartheid como política social. 
A conferencia tinha como objetivos avaliar a recepção da DUDH na sociedade internacional como também planejar os rumos dos Pactos recém assinados. Especificamente, a incumbência era: (i) rever o progresso que foi feito no campo dos direitos humanos desde a adoção da DUDH; (ii) avaliar a efetividade dos métodos e técnicas usadas pela ONU no campo dos direitos humanos e (iii) formular e preparar um programa de medidas adicionais a serem tomadas subsequentemente ao Ano Internacional dos Direitos Humanos proposto pela Jamaica, em 1963, para comemorar os vinte anos da DUDH. $^{98}$

A conferencia foi realizada em Teerã, de 22 de abril a 13 de maio de 1968, e contou com a participação de 84 estados-membros e por representantes de diversos órgãos e agencias especializadas da ONU, organizações regionais e ONGs, sendo concluída com a adoção, por unanimidade, da Proclamação de Teerã e mais 29 resoluções que tratavam de temas como a discriminação racial, autodeterminação, direitos humanos e conflitos armados, etc. ${ }^{99}$

Interessante observar da Declaração de Teerã ${ }^{100}$ é o momento em que se passa a conferencia vinte anos depois da DUDH. O ano de 1968 foi marcante na historia contemporânea por suas lutas por direitos e, consequentemente, para o avanço do Direito Internacional dos Direitos Humanos. Ora, se os direitos humanos são uma construção histórica consequência da conquista de direitos, o movimento feminista, o movimento estudantil, as manifestações contra a Guerra do Vietnã, a luta pelos direitos dos negros nos EUA, a abertura para assinaturas do Tratado de Não-Proliferação de Armas Nucleares, o auge da política do Apartheid, as ditaduras militares na América Latina, entre outros

\footnotetext{
${ }^{98}$ Proclamação de Teerã, $\S 1^{\circ}$ : “On 10 September 1963, to commemorate the twentieth anniversary of the adoption and proclamation of the Universal Declaration of Human Rights, Jamaica requested that the item entitled "Designation of 1968 as International Year for Human Rights" be included in the agenda of the eighteenth session of the General Assembly (A/5493). At that session, on 20 September 1963, the General Assembly decided to include the item in its agenda and allocated the matter to its Third Committee (A/PV.1209). On 12 December 1963, following the recommendation of its Third Committee (A/5660), the General Assembly adopted resolution 1961 (XVIII) by which it designated 1968 as International Year for Human Rights."

99 "At the conclusion of the first International Conference on Human Rights, held in Teheran from 22 April to 13 May 1968 at the invitation of the United Nations General Assembly (resolution 2081 (XX) of 20 December 1965), the representatives of the 120 participating States adopted the Proclamation of Teheran by consensus. It was annexed to the Final Act of the Conference (A/CONF.32/41) and endorsed that same year by the General Assembly in its resolution 2442 (XXIII) of 19 December 1968. The Proclamation assessed progress achieved since the adoption of the Universal Declaration of Human Rights on 10 December 1948 and set forth a plan of action for the future."

100 "Proclamation of Teheran, Final Act of the International Conference on Human Rights, Teheran, 22 April to 13 May 1968, U.N. Doc. A/CONF. 32/41 at 3 (1968)". Disponivel em http://untreaty.un.org/cod/avl/pdf/ha/fatchr/Final_Act_of_TehranConf.pdf
} 
eventos ligados direta ou indiretamente à agenda política dos direitos humanos, fizeram do ano de 1968 um ano especial para os direitos humanos. Outrossim, no momento da sua adoção, os Estados reunidos já consideravam as novas oportunidades disponíveis pelo rápido progresso da ciência e tecnologia. Estamos falando de 1968, um ano antes do homem caminhar na lua. Não se olvida, ainda, a Conferencia em manifestar-se em relação à guerra e à violência crescente dentro das nações.

Believing that, in an age when conflict and violence prevail in many parts of the world, the fact of human interdependence and the need for human solidarity are more evident than ever before,

A Proclamação de Teerã é um programa para o futuro da DUDH. Ela convoca os Estados-membros a cumprirem suas obrigações internacionais em matéria de direitos humanos, reafirmando os valores contidos e os compromissos decorrentes da DUDH, dos recentes PIDCP e PIDESC, da Convenção Internacional sobre a Eliminação de Todas as Formas de Discriminação Racial, como também dos outros instrumentos adotados à época. Reafirma o principio da não-discriminação de qualquer natureza, a importância da proteção da família, da liberdade de expressão, de informação, de consciência e de religião, da criança e o adolescente, etc.

A Proclamação foi mais enfática, contudo, na afirmação da inadmissibilidade do regime do apartheid, elevando o tema como questão de maior gravidade para a comunidade internacional.

Outro tema importante é a reafirmação da Declaração de Independência dos Países e Povos Coloniais - documento que pôs fim ao período de neocolonialismo - aportando mais de uma centena de novos países para o seio da ONU com obrigações ante à Carta e à DUDH. Neste sentido, a Proclamação reconhece o abismo entre os países desenvolvidos e os tidos em vias de desenvolvimento e reitera a indivisibilidade dos direitos humanos, em especial, a atenção dada aos direitos econômicos, sociais e culturais e a necessidade de avançar no desarmamento.

$\mathrm{O}$ documento não faz menção direta à EDH. Dizemos direta uma vez que o faz, indiretamente, ao reafirmar os direitos contidos na DUDH. Faz, não obstante, menção ao direito à educação lato sensu e à terrível situação à época em escala global ao afirmar que:

A existência de setecentos milhões de analfabetos no mundo é um enorme obstáculo para todos os esforços para realizar os objetivos e propósitos da Carta da ONU e as provisões da DUDH. Ação internacional objetivando erradicar o analfabetismo da face da Terra e promovendo educação em todos os níveis 


$$
\text { requer atenção urgente. }{ }^{101}
$$

Vinte e cinco anos mais tarde, em 1993, finalmente, um evento de suma importância para o desenvolvimento dos direitos humanos - talvez o mais importante desde a própria DUDH - foi realizado. A Conferência Mundial sobre Direitos Humanos, realizada em Viena, resultou na Declaração de Viena e seu respectivo Plano de Ação. Este evento repercutiu decisivamente nas deliberações e nos resultados de todas as demais grandes conferências da década de noventa. A partir dela, os direitos humanos deixaram de cumprir um papel secundário na política internacional para, finalmente, assumir uma posição de protagonismo, entendidos como atributos inerentes à todas as pessoas e nessa qualidade, devendo ser positivados pelo Direito como razão de ser das sociedades modernas politicamente organizadas. A Conferencia de Viena serviu para consolidar o entendimento sobre o que são os direitos humanos 45 anos depois da adoção da DUDH. Reafirma os princípios da dignidade humana e o da não-discriminação de nenhuma espécie. Enaltece o multiculturalismo afirmando que ele não é incompatível com os direitos humanos.

Entretanto, apesar de ratificar os princípios e direitos já enunciados em outros instrumentos de direitos humanos, a Declaração de Viena e seu Plano de Ação, concentraram esforços em buscar soluções que pudessem aprimorar o mecanismo internacional de promoção e proteção de tais direitos. À época, ainda operava a extinta Comissão de Direitos Humanos que era muito criticada por sua pouca agilidade. Meios alternativos para reformar este mecanismo eram necessários para cumprir o disposto no artigo 56 da Carta da ONU que propugnou que "todos os membros da Organização se comprometem a agir" para atender ao propósito do artigo 55 de "criar condições de estabilidade e bem estar, necessárias às relações pacíficas e amistosas entre as Nações, baseadas no respeito ao princípio da igualdade de direitos" e "o respeito universal e efetivo dos direitos humanos e das liberdades fundamentais para todos."

A Declaração afirma a necessidade de racionalizar e aprimorar as medidas adotadas pela ONU no campo dos direitos humanos com o objetivo de fortalecer tais ações e, para este fim, a comunidade internacional deve encontrar meios para desviar dos obstáculos para o progresso substancial do respeito e realização dos direitos humanos, como o são a discriminação de qualquer espécie - notadamente baseada no gênero -, a questão do multiculturalismo, a falta de reconhecimento da importância dos direitos humanos, a carência de investimentos internacionais e nacionais neste campo, etc.

\footnotetext{
${ }^{101}$ Cf Declaração de Teerã.
} 
Imbuída do espírito de nossa era e da realidade de nosso tempo, que exigem de todos os povos do mundo e todos os Estados Membros das Nações Unidas empreendam com redobrado esforço a tarefa de promover e proteger todos os direitos humanos e liberdades fundamentais, de modo a garantir a realização plena e universal desses direitos. ${ }^{102}$

Para o aprimoramento da coordenação dos direitos humanos no sistema da ONU, a Declaração de Viena propõe que seus órgãos, entidades e agencias especializadas cujas atividades estejam voltadas aos direitos humanos, trabalhem em cooperação com o objetivo de fortalecer, racionalizar e canalizar suas atividades, sem assumir o risco de duplicar sua atuação. Ela aproveita a oportunidade, e, na mesma esteira de avançar com o DIDH, cobra a ratificação dos tratados internacionais dos direitos humanos pelos Estados que ainda não o fizeram, como também, aos que já o tenham feito, para reverem suas reservas, caso haja, e em caso negativo, para aumentar esforços na implementação de seu conteúdo.

Outro nítido sinal da intenção da Declaração de Viena de aprimorar o mecanismo de proteção e promoção dos direitos é a sugestão da criação do posto de Alto Comissário para os Direitos Humanos, elevando atenção ao tema, conforme dispõe o artigo 18:

\section{The World Conference on Human Rights recommends to the General Assembly that when examining the report of the Conference at its forty-eighth session, it begin, as a matter of priority, consideration of the question of the establishment of a High Commissioner for Human Rights for the promotion and protection of all human rights.}

Esta proposta foi prontamente aceita pela Assembleia Geral que criou em dezembro do mesmo ano o posto de Alto Comissário das Nações Unidas para os Direitos Humanos, ocupado hoje pela sul-africana Navi Pilay, afirmando o notável resultado da Conferencia.

Além de dar importância ao tema dos direitos humanos, o programa de ação resultado da Conferencia propõe aos Estados concentrarem esforços nas seguintes frentes: (i) reconhecer a universalidade dos direitos humanos; (ii) reiterar que os direitos humanos são indivisíveis, independentes e inter-relacionados; (iii) compreender que o multiculturalismo e a universalidade dos direitos humanos são compatíveis; (iv) reconhecer o vínculo estreito entre a democracia, o desenvolvimento e o respeito pelos direitos humanos e (v) reconhecer e afirmar que o desenvolvimento é um direito.

No tocante à EDH, o Plano de Ação de Viena dedica todo uma sessão ${ }^{103}$, afirmando que a educação, a formação e a informação pública são essenciais para a promoção e realização de relações harmoniosas entre as comunidades, fomentando o entendimento

\footnotetext{
${ }^{102}$ Preâmbulo da Declaração de Viena.

${ }^{103}$ Convenção de Viena, seção D, arts. 78-82.
} 
mutuo, a tolerância e a paz. (Art. 78). Para tanto, convoca os Estados e instituições a incluir os direitos humanos, o direito humanitário, a democracia e o Estado de Direito no currículo de todas as instituições de ensino formais e não-formais.

The World Conference on Human Rights in the Vienna Declaration and Programme of Action (in particular, para. 33 of Section I) stated that human rights education, training and public information were essential for the promotion and achievement of stable and harmonious relations among communities and for fostering mutual understanding, tolerance and peace. The Conference recommended that States should strive to eradicate illiteracy and should direct education towards the full development of the human personality and the strengthening of respect for human rights and fundamental freedoms. It called on all States and institutions to include human rights, humanitarian law, democracy and rule of law as subjects in the curricula of all learning institutions in formal and non-formal settings.

Avança no próprio entendimento sobre a $\mathrm{EDH}$, notando que ela inclui a paz, democracia, desenvolvimento e justiça social, para que se consiga um entendimento comum dos direitos humanos, fortalecendo a universalidade destes direitos ${ }^{104}$. Medidas sugeridas a serem aplicadas incluem o desenvolvimento de programas e estratégias específicas para assegurar a mais ampla EDH e a disseminação de informação pública, levando em consideração a não-discriminação, em especial, a baseada no gênero ${ }^{105}$.

E finalmente, enuncia medidas a serem tomadas no tocante à $\mathrm{EDH}^{106}$ já definindo muito do que hoje, 18 anos depois, temos sobre a EDH. A motivação para a inclusão de elementos da EDH acompanha o movimento crescente dedicado à causa e foi influenciado diretamente pelo Congresso sobre a Educação para os Direitos Humanos e Democracia realizado pela UNESCO em março de 1993, em Montreal.

"Os Governos, com o apoio das organizações intergovernamentais, das instituições nacionais e das organizações não-governamentais, deverão promover uma maior consciencialização para os Direitos Humanos e para a tolerância mútua. A Conferência Mundial sobre Direitos Humanos sublinha a importância do reforço da Campanha Mundial de Informação ao Público em matéria de Direitos Humanos promovida pelas Nações Unidas. Tais entidades deverão empreender e apoiar a educação em matéria de Direitos Humanos e divulgar de forma efetiva informação ao público neste domínio. Os serviços consultivos e os programas de assistência técnica do sistema das Nações Unidas deverão ser capazes de responder imediatamente a pedidos dos Estados relativos a atividades educacionais e de formação nesta matéria, bem como à educação específica sobre normas contidas em instrumentos internacionais de Direitos Humanos e de Direito Humanitário e a sua aplicação a grupos especiais tais como as forças armadas, os funcionários responsáveis pela aplicação da lei, a polícia e os especialistas na área da saúde. Deverá ser considerada a proclamação de uma década das Nações Unidas para a educação em matéria de Direitos Humanos, por forma a promover, encorajar e fazer sobressair este tipo de atividades

\footnotetext{
${ }^{104}$ Convenção de Viena, arts. 79 e 80.

105 Ibid., art. 81 .

106 Ibid., art. 82.
} 
educativas."

Não só a recomendação para a criação do cargo do Alto Comissário das Nações Unidas foi acolhida ainda em 1993, mas sobretudo, no mesmo ano, por recomendação da Declaração de Viena desenhou-se os programas mundiais de EDH.

Assim Sendo, a Conferencia de Viena teve papel fundamental na consolidação dos direitos humanos e, consequentemente, na atenção atraída para eles. Suas recomendações foram adotadas de plano pelo sistema ONU e foram de tamanha importância que acabaram por influenciar diretamente a reforma da própria levada a cabo em 2006.

\subsection{A breve história da educação em Direitos Humanos}

Respeitando o marco metodológico desta dissertação - a concepção contemporânea dos direitos humanos trazida pela adoção da DUDH - comentaremos sobre as esparsas iniciativas que iniciaram o processo de EDH no período inicial do pós-guerra saltando para o momento de maior atividade neste campo - em especial as últimas três décadas culminando na formulação de um plano internacional comum sobre a EDH a ser implantado nos sistemas educacionais nacionais, processo que ocorre atualmente.

Primeiramente, alguns esclarecimentos são necessários. Apesar de ser possível observar algumas iniciativas internacionais que poderiam ser consideradas EDH mesmo antes da Primeira Guerra - como são as campanhas internacionais sobre a abolição da escravidão envolvendo algumas poucas ONGs, foi mesmo no pós Segunda Guerra que esforços neste sentido foram empregados em decorrência da internacionalização trazida, sobretudo, pela criação da ONU e as relações econômicas.

Dissemos que a DUDH inaugurou princípios, valores e direitos. Como a EDH é derivada daquela, parte deste documento como sua alma mater. Então, a EDH é a educação sobre os princípios, valores e direitos contidos na DUDH e nos instrumentos subsequentes. Aqui notamos três facetas da EDH: (i) educar sobre os princípios; (ii) educar sobre os valores e (iii) educar sobre os direitos. A integralidade destas três características somente foi elaborada nos últimos vinte anos, sendo assim, não consideraremos experiências educacionais que se assemelham ou que transmitem valores ou princípios da DUDH de maneira coincidente. Ora, vimos afirmando que os direitos humanos, por serem uma construção histórica, vêm sendo construídos com base nas doutrinas filosóficas e religiosas, por exemplo. Inescapavelmente, haverá educação, de qualquer natureza, cujos valores condizem com os valores da DUDH. Porém, consideraremos EDH apenas 
processos baseados diretamente no movimento de ordenamento internacional e tendo como objeto principal a educação para a nova realidade internacional no tocante aos direitos humanos lançados com a DUDH.

Se considerarmos EDH toda a educação coincidente em valores e princípios, certamente remontaremos ao inicio do processo civilizatório. Não é o caso. Portanto, entenderemos EDH como a educação sobre os princípios, valores e direitos contidos na DUDH a partir dela, e sobre tudo, baseada nela. Tendo ela e o sistema da ONU como objeto principal.

Outra característica da EDH é o que podemos chamar de educação indireta em EDH, a ser admitida assim em sua fase inicial. Uma vez adotada, era preciso espalhar a retórica da DUDH entre todas as nações do planeta. Neste momento, teve inicio árduo trabalho de difusão mundo afora e, neste contexto, cumpre ressaltar a importância das organizações internacionais, que, apesar de não se envolverem diretamente com a EDH - por ela própria ser uma construção recentíssima - os programas das organizações internacionais acabavam e acabam, direta ou indiretamente, levando a bandeira da DUDH. A OMS, por exemplo, afirma não ter uma política educacional voltada para a EDH, no entanto, suas campanhas sobre a saúde referem-se comumente a ela como direito, promovendo, explicita ou implicitamente, a DUDH. Por seu turno, a FAO, apesar de contar com programas educacionais, informa que somente foca o direito à alimentação sem ter um contexto de EDH. Este movimento também envolvem as ONGs internacionais, por exemplo, o CICV que, apesar de tratar do direito humanitário, cumpre importante papel na difusão da DUDH até os dias de hoje. De certo, essas experiências não se tratam de EDH diretamente como entendemos atualmente, mas são movimentos importantes embrionários dela e, por propagar os valores da DUDH são, de forma ou outra, parte integrante da EDH a seu tempo. As organizações internacionais levavam a palavra da DUDH mesmo que indiretamente sob o plano de difundir o Direito Internacional e, por conseguinte, o DIDH, mesmo que sem referência direta a este.

A partir de 1945, as nações do mundo inteiro dedicavam atenção para primeiro (i) entender que mundo novo resulta da criação da ONU; e, segundo para (ii) organizar esse novo mundo, participar da formação da sociedade internacional legal, comercial, humanitária, de causas comuns, buscando o propósito final da paz. Imediatamente os esforços para a implantação desta nova ordem em todas as esferas começaram. Uma quase total adaptação dos ordenamentos jurídicos, sociais e culturais deveria ser posta em marcha 
através de um plano de ação para que esta nova tentativa de estabelecimento de uma ordem internacional não fosse frustrada. A sedimentação destes novos valores e regras a serem observadas passa naturalmente pela absorção deles pelas culturas locais, nacionais. E o meio inexorável para essa tarefa é a educação que, dessa maneira, sofreria influencia direta desta nova ordem.

A necessidade de adequar a educação desenvolvida em nível nacional à nova realidade internacional teve como seus principais vetores as disciplinas de Historia, Direitos Cívicos, Estudos Sociais, Educação Moral, entre outras, encontrando variações conforme as particularidades locais. Essas disciplinas sofreram direta influencia dos eventos ONU e DUDH. Ou, ao menos, deveriam sofrer. Essa influencia encontrou, não obstante, a barreira do nacionalismo e a ideia da soberania volta a incomodar.

\begin{abstract}
Educational systems were and are so securely in the hands of national states and societies that it seemed obvious that schooling mainly reflects variations in national economic and political systems. It also seemed obvious that schooling emphasizes national history, society and citizenship. Mindful of the dangers of nationalistic jingoism, progressives favored a civic education that fostered a more liberal and open-minded and tolerant citizenry. But citizenry formation was still linked to the needs of a particular country rather than the "requirements" of human members in a global society. ${ }^{107}$
\end{abstract}

Além disso, não parece atraente para um Estado, principalmente o autocrático, estimular o conhecimento sobre a limitação de suas ações devido a um ordenamento internacional superior. Mais ainda, empoderar sua população com o conhecimento de direitos reconhecidos internacionalmente. Recordemos que as décadas seguintes à Segunda Guerra não são reconhecidas como o auge da democracia no mundo. Em verdade este cenário somente se apresenta em meados da década de oitenta.

A EDH é comumente confundida com a educação para a cidadania. O objetivo é comum: formar cidadãos. Sem embargo, a questão da cidadania carrega forte carga axiológica preenchida pelos valores nacionais. O nacionalismo, sob certa ótica, pode ser contrario ao objetivo da EDH. A educação para a cidadania considera primeiro o cidadão e seu regramento interno nacional. Visa formar o cidadão dentro dos valores culturais transmitidos pela educação nacional. A pátria e a historia são elevados à categoria de valores essenciais para formar o cidadão. Por seu turno, a EDH visa formar o cidadão global, internacional, preparado para adimplir com os desígnios deste novo mundo.

\footnotetext{
${ }^{107}$ RAMIREZ, F. O.; SUAREZ, D.; MEYER, J.. The Worldwide rise of human rights education. Stanford University, 2005. $\quad$ p. 05. Open Access. Disponível em http://servidormanes.uned.es/mciud/eventos/articulos_rodr/Ramirez-Suarez-Meyer_5_15_05_final\%202.pdf. Acesso em: 15 Mar. 2011.
} 
É comum a educação para cidadania ser entendida como se fosse meramente uma educação cívica. Ou seja, como se fosse necessário e suficiente pregar o culto à pátria, seus símbolos, heróis e datas históricas, assim como fomentar um nacionalismo ora ingênuo ora agressivo (...). Torna-se necessário entender educação para a cidadania como formação do cidadão participativo e solidário, consciente de seus deveres e direitos e, então, associá-la à educação em direitos humanos. Só assim teremos uma base para uma visão mais global do que seja uma educação democrática, que é, afinal, o que desejamos com a educação em direitos humanos, entendendo "democracia" no sentido mais radical - radical no sentido de raízes -, ou seja, como o regime da soberania popular com pleno respeito aos direitos humanos. ${ }^{108}$

A explicação para a mudança em direção à EDH é a sua ligação com o processo de globalização: eles avançam interligadamente. A EDH reflete a ênfase no reconhecimento da cidadania global. O conceito da pessoa humana é mais evocado que o do cidadão nacional. Outrossim, em que pese a barreira do nacionalismo, a educação é matéria tendente a absorção internacional sendo comum as metodologias e matérias ensinadas serem absorvidas pelos outros sistemas de outras nacionalidades - certamente entre nações com matrizes cultural análogas - através de intercâmbios culturais e educacionais.

Os anos iniciais foram um período de pouca atividade internacional na área dos direitos humanos e menos ainda no campo da EDH - tendência quebrada somente com o Seminário Internacional sobre Ensino dos Direitos Humanos ${ }^{109}$, realizado em 1952, nos Países Baixos, e o inicio do projeto Escolas Associadas UNESCO, em 1953, ambas iniciativas desta agencia especializada.

Sem embargo, a EDH evolui e vem evoluindo, encontrando hoje seu clímax com o projeto de Declaração objeto desta dissertação. Em síntese, a expansão da EDH deve-se principalmente por três razoes: (i) a expansão da educação lato sensu; (ii) o processo de internacionalização (ou globalização) decorrentes da criação da ONU; e (iii) a evolução do DIDH.

Naturalmente, a EDH acompanha o desenvolvimento do direito à educação lato. Após a criação da ONU, a importância dada à educação ganhou outro entendimento, sendo que, até este momento, ela era ou subestimada, ou mesmo entendida por alguns como razão para o descontentamento social e, portanto, prejudicial para as sociedades.

In the brave new post-war world, the idea that there could be "over-education" a common earlier fear that too much education might generate social conflict and disorder - dropped out of sight. If education is now seen as generalized human capital, more of it is a good thing (see the striking emphasis on the point

\footnotetext{
${ }^{108}$ BENEVIDES, M. V.. Fé na luta: a comissão justiça e paz de São Paulo, da ditadura à democratização. São Paulo: Lettera.doc, 2009, p. 325.

${ }^{109} \mathrm{O}$ nome oficial do evento é Seminar on Education for World Citizenship with Special Reference to the Principles of the Universal Declaration of Human Rights, conforme resolução 9.2161 de 1951.
} 
in World Bank 2000). So both for the collective good, and for individual benefit, educational expansion lost many of its limits. Its earlier detractors have simply been out competed by an array of education supporters. ${ }^{110}$

Esta ideia perde força com o entendimento de ser a educação o único caminho para socializar os indivíduos em sociedades tão complexas quanto às sociedades industriais contemporâneas, interligadas no ordenamento internacional, que vale dizer, ocorre em todas as áreas, incluindo a econômica. O fim do neocolonialismo e os programas de fomento ao desenvolvimento elevaram a importância dada à educação em escala global. Investimentos em educação em países pobres ou colonizados foram significativos e suficientes para garantir quase que universalmente a educação primaria, malgrado a baixa qualidade.

Assim, a educação acompanha o processo de globalização política, cultural e econômica e a percepção da interdependência trazida por ele. $\mathrm{O}$ aprendizado de línguas estrangeira - antes somente reservado à mais alta classe intelectual - agora torna-se necessário para todos, não somente com intuitos profisssionais, mas também como condição de inserir-se na cultura globalizada. As escolas adaptam-se a esses modelos visando preparar o cidadão para este mundo globalizado. O cidadão do mundo que buscará trabalho na expansão das empresas transnacionais.

Os modelos de sociedade nacional fechados com sua preferencia em adequar indivíduos num papel social e ocupacional predefinido caíram em desuso dando espaço aos modelos expandidos de individuo como possuidor de capital humano em um sociedade global expansiva. Portanto a expansão da EDH é vista como acessória à evolução da educação lato sensu, como não poderia deixar de ser.

\section{For one thing, it signifies a world organized around individual development. For another, a most immediate goal of the educational expansion movements "going on under the "Education for All" umbrella is to teach individuals around the world about their entitlement to education itself (Chabbott, 2003) ${ }^{111}$}

$\mathrm{Na}$ década de sessenta, eventos de direitos humanos começam a aproximar a educação à EDH ao avançar sobre temas ligados àquela, tratando sobre a discriminação na esfera do ensino ${ }^{112}$ e do fomento à juventude dos ideais de paz, respeito mutuo e compreensão entre os $\operatorname{povos}^{113}$, por exemplo. Novo período de atividades somente foi

\footnotetext{
${ }^{110}$ RAMIREZ; SUAREZ; MEYER, 2005, p. 5.

${ }^{111}$ Ibid., 2005. p. 11.

${ }^{112}$ Através, por exemplo, da Convenção relativa à luta contra as discriminações na esfera do Ensino, em 1960.

${ }^{113}$ Declaração sobre o fomento a juventude dos ideais de paz, respeito mutuo e compreensão dos povos, em 1965.
} 
observado uma década depois com a Recomendação sobre a Educação para a Compreensão, a Cooperação e a Paz Internacional e a Educação relativa aos Direitos Humanos e as Liberdades Fundamentais, de autoria da UNESCO, em 1974. No ano seguinte, a comunidade internacional adota a Declaração sobre a Utilização do Programa Científico e Tecnológico em Interesse de Paz e no Beneficio da Humanidade. Estes últimos eventos ocorrem em paralelo ao desenvolvimento do DIDH, que, como vimos, dispara a partir de meados da década de setenta. Com o avanço das organizações e instrumentos, o DIDH torna-se tema global e representa um assunto frequente na agenda internacional passando, destarte, a ganhar importância no modelo de educação dirigida à formação do cidadão global, permitindo o desenrolar da EDH.

Neste período, a cada ano entre 1970 e meados de 1990, o numero de organizações de direitos humanos excedeu o numero de fundações em anos anteriores, demonstrando a evolução crescente dos direitos humanos. Destaque certamente para fundação da Anistia Internacional, anos antes, em 1966, que se tornaria, devido ao seu formidável crescimento, uma das principais mandatárias dos direitos humanos e posteriormente também da EDH, na esfera não-governamental. Antes da DUDH não existia nenhuma organização intergovernamental de direitos humanos. Em 1990, existiam 27 delas ${ }^{114}$. Este avanço foi influenciado também pelos investimentos dirigidos aos direitos humanos. Por exemplo, até o inicio da década de 1970 as grandes fundações estadunidenses raramente financiavam trabalho internacional dos direitos humanos. De 1977 a 1987, contudo, os investimentos nesta área cresceram significantemente em números de programas financiados e nos valores investidos ${ }^{115}$.

Como vemos, a EDH acompanha - como não poderia deixar de ser - o desenvolvimento dos direitos humanos e o entendimento e expansão deles. No principio, a EDH continha basicamente os conceitos do direito ao devido processo legal. Posteriormente, o tema expande tratando temas nas áreas econômica, social, política, educacional, médica e temas culturais, conforme avança o DIDH.

No primeiro momento, a preocupação por promover os instrumentos de direitos humanos desviou a EDH do ensino formal e quase toda a formação em direitos humanos era uma formação legalista, para advogados. A ênfase era legal porque os Estados estavam assinando e ratificando documentos que formariam o Direito Internacional. Essa ênfase foi

\footnotetext{
${ }^{114}$ RAMIREZ; SUAREZ; MEYER, 2001, p. 8.

${ }^{115}$ RAMIREZ; SUAREZ; MEYER, 2001, loc. cit.
} 
perdida quando educadores começaram a entender a relevância dos diretos humanos no sistema de educação formal e devido à uma melhor interação destes com os juristas.

É na década de noventa, contudo, que a EDH ganha uma concepção mais holística. A partir de 1995, a ONU e suas agencias aumentam a produção de suas elaborações clarificando que a educação e a aprendizagem dos direitos humanos "tem componentes de conhecimento, habilidades e atitudes, os quais devem ser consistentes com o reconhecido pelos princípios de direitos humanos que devem empoderar os indivíduos e grupos abordando o tema da opressão e injustiça"116. Essa produção sugere que a EDH é aquela destinada a prover habilidades, conhecimento e motivação aos indivíduos para que estes transformem suas próprias vidas e realidades ${ }^{117}$. Logo, ela é transformativa e comportamental.

A EDH vem avançando em escala global mais notadamente nas ultimas décadas e segue um movimento progressivo, Resoluções foram adotadas, conferencias realizadas e planos de ação lançados por diversas agencias da ONU, não apenas a UNESCO. O Conselho da Europa é o mais ativo neste campo como o é nos outros. Quer queira quer não, o sistema europeu é o mais avançado sistema regional de direitos humanos na atualidade. Isso somado aos esforços de grandes ONGs como a Anistia Internacional, Concern, Care, entre outras dezenas de organizações internacionais dedicadas ao tema. A matéria também é corrente em inciativas das organizações internacionais, das associações profissionais e de grupos de advocacia internacional. Hoje, seus princípios parecem haver penetrado os planos curriculares, políticas públicas, material didático e práticas em muitas sociedades, como veremos adiante.

Sem embargo, apesar da enorme evolução notada nos últimos vinte anos, o problema da EDH acompanha o problema dos direitos humanos em geral, qual seja, a falta de efetivação. Por isto, em seguida, analisaremos as iniciativas principais da ONU objetivando a efetivação da EDH, principalmente em âmbito nacional.

\subsubsection{A experiência da $\mathrm{ONU}$}

Como sabemos, a ONU é o principal órgão de fomento dos direitos humanos

\footnotetext{
${ }^{116}$ Relatório da Anistia Internacional: Amnesty Internacional, 2007; Ásia-Pacific Regional Centre for Human Rights Education, 2003., Disponível em inglês em http://www.hrea.org/pubs/tibbitts08-encyclopedia.pdf.

${ }^{117} \mathrm{Cf}$ TIBITS, Felisa. Overview of research and evaluation within human rights education. Apresentação no congresso "Human Rights Education for Social Change: Evaluation Approaches and Methodologies". Equitas, Maio 3-5 de 2007. Montreal, Canadá.
} 
consoante sua função orgânica. Após a adoção da DUDH, ela, dentre incontáveis desafios, dá inicio ao processo de consolidar seu conteúdo dentro das sociedades nacionais.

Nas primeiras décadas, os esforços foram incipientes, condicionados à adaptação do mundo à nova realidade. Trata-se, desde o inicio, de uma tarefa conjunta, cujo ator principal é a ONU, através, primordialmente, da UNESCO.

Em 1942, ainda durante os combates da Segunda Guerra Mundial, os governos dos países aliados europeus reuniram-se no Reino Unido para a conferencia Allied Ministers of Education (CAME). Embora o fim da guerra estivesse longe, esses países buscavam meios para reconstruir seus sistemas educacionais para quando a paz fosse restaurada. Rapidamente a iniciativa ganhou força atraindo a adesão dos EUA e outros países. Desta Conferencia resulta a proposta de nova conferencia para criar uma organização educacional e cultural em nível global. Em novembro de 1945, já sob os auspícios da ONU, 44 países decidiram criar uma organização para incorporar uma genuína cultura de paz com o objetivo de estabelecer "intellectual and moral solidarity of mankind and, in so doing, prevent the outbreak of another world war". Desse modo, em 16 de novembro de 1945, com a adesão de vinte países ${ }^{118}$, é criada a UNESCO.

A UNESCO sempre foi a maior mandatória da EDH na esfera da ONU, tendo ela mesmo participado, inclusive, da elaboração da DUDH. Explica-se: a tarefa de elaborar a DUDH foi atribuída ao ECOSOC. Assim que foi criada, a UNESCO auxiliou-o nos preparativos para a elaboração da DUDH ao consultar filósofos e catalogar suas opiniões a respeito dos direitos humanos, exaurindo o documento chamado Human Rights Symposium, de 1948. Naquele momento, esse documento foi considerado pela própria UNESCO como uma coleção dos mais significantes textos reunidos sobre as bases filosóficas dos direitos humanos. Contribuíram para o documento nomes como Mahatma Gandhi, Boris Tchechko, Aldous Huxley, Edward Carr, Benedetto Croce, dentre outros tantos. Este documento serviu de base filosófica para orientar os trabalhos dos redatores da DUDH.

Em 1952, a UNESCO organizou, nos Países Baixos, o já referido primeiro seminário internacional sobre a EDH sob o nome Seminar on Education for World Citizenship with Special Reference to the Principles of the Universal Declaration of Human Rights. O

\footnotetext{
${ }^{118}$ Os vinte países eram: África do Sul, Arábia Saudita, Austrália, Brasil, Canadá, China, Dinamarca, Egito, EUA, França, Grécia, Índia, Líbano, México, Nova Zelândia, Noruega, Reino Unido, Republica Dominicana, Tchecoslováquia e Turquia.
} 
documento resultado deste seminário pode ser considerado a primeira versão sobre a EDH da historia e muito do seu conteúdo é ainda presente nos planos de EDH atuais. O próprio seminário se proclama experiments in international understanding.

Do programa do Seminário, que em verdade, trata-se de uma serie de seminários ao longo de um mês, discutiu-se desde metodologias até propostas de temas a serem inseridos, como os conceitos de universalidade, do estado de direito, do direito à participação no governo, da liberdade de expressão e crença, do direito à educação, à previdência social e à participação na vida cultural da comunidade. Não obstante, apesar de seu conteúdo ser surpreendentemente atual, o publico alvo objeto deste seminário era a criança tão somente, tratando-se, portanto, exclusivamente da educação praticada nas escolas.

No ano seguinte, e por influência deste evento, tem inicio a primeira tentativa de educação internacional da UNESCO com o projeto Escolas Associadas (Associated Schools Project). Este projeto objetivou a difusão da DUDH e das atividades da ONU e continua até hoje. Não há dados sobre a EDH provida nas escolas durante as primeiras três décadas da DUDH, sem embargo, em 2005, o projeto incluía mais de 7.793 instituições de ensino, espalhadas em mais de 175 países, envolvendo desde a pré-escola até a formação de professores. Em 2003, o projeto adotou novo plano de ação indicando que os esforços devem ser concentrados nos quatro pilares do material "Learning for the 21st Century" adotado com o Dakar Framework of Action - "aprender a saber, a fazer, a ser e a viver em conjunto", de 2000.

A própria UNESCO reconhece que seu trabalho no tocante à EDH somente ganhou força nas ultima décadas. Não é que sua tarefa era somente introduzir a EDH nos instaurados e eficientes sistemas educacionais no mundo. Seu trabalho foi por muito tempo advogar pela educação lato sensu na maior parte do mundo e estes esforços perduram até os dias atuais. Entretanto, os caminhos da luta pela educação lato e a EDH começaram a se aproximar, como vimos anteriormente, chegando ao ponto de podermos dizer que atualmente estão intrinsecamente ligados, sendo um só caminho. Não se advoga mais pela educação para todos se a EDH não for levada em consideração. Isso se deve pela influencia, entre outras, da Recomendação referente à Educação para o Entendimento, Cooperação e Paz e Educação relacionada aos Direitos Humanos e Liberdades Fundamentais, de 1974, e a Declaração e Programa Integrado de Ação sobre a Educação para a Paz, os Direitos Humanos e a Democracia, de 1995. A Recomendação de 1974 ainda hoje cumpre a função de monitorar regularmente o trabalho no terreno em parceria 
com as Comissões Nacionais da UNESCO, em nível ministerial.

Em 1993, contemporânea à Conferencia Mundial de Direitos Humanos de Viena, a UNESCO organizou um congresso em Montreal chamado Congresso sobre a Educação para os Direitos Humanos e Democracia, como mencionamos antes. Este evento exaure um documento sob o título Human Rights Teaching que compreende todo o discutido neste congresso, avançando a EDH, direta e decisivamente, ao influenciar o evento vienense cuja importância também já foi apontada.

No ano seguinte, ela lança o programa Cátedra da UNESCO nas Universidades para promover a cooperação através do twining ${ }^{119}$ e outros meios de colaboração entre instituições de ensino superior de todo o mundo, permitindo o acesso ao conhecimento nacional e internacionalmente. $\mathrm{O}$ objetivo deste programa é intercambiar conhecimento produzido nas universidades sobre os temas mais variados como a paz e os direitos humanos, a bioética, o turismo cultural, a educação, etc.

É somente em 2003, todavia, que a UNESCO converge seu foco para a EDH como prioridade a ser incorporada em todos os seus programas educacionais. Esta guinada tem inicio com o lançamento do programa UNESCO and Human Rights Education, que traça uma estratégia para a EDH em suas atividades, conforme adotada pela a Conferencia Geral em sua $32^{\mathrm{a}}$ Sessão e foi influenciada pelo desenvolvimento do Conceito do Human Rights

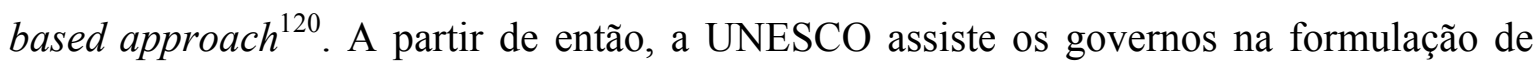
políticas públicas, estratégias, planos de ações e programas para garantirem a EDH e facilitar o diálogo e cooperação entre os diversos atores. Importante observar o relevante papel que a UNESCO cumpre no programa Educação para Todos e seus esforços na área da educação para atingir-se às Metas do Desenvolvimento do Milênio.

A UNESCO trabalha tanto no avanço e na qualidade da educação e o acesso a ela ${ }^{121,}$ como sugere conteúdos - por exemplo, os direitos humanos - nos programas educacionais nacionais e é, sobretudo, protagonista no Programa Mundial para a Educação em Direitos Humanos, iniciado em 2005, ao assistir os Estados-membros a elaborarem e executarem seus planos nacionais de EDH, conforme dispõe o respectivo Plano de Ação.

Desta forma, a UNESCO trabalha focada na implementação do direito humano à

\footnotetext{
${ }^{119} \mathrm{O}$ vocábulo inglês Twining significa, segundo o dicionário Michaelis, tornar-se gêmeos, juntar (em um par), acasalar.

${ }^{120}$ Cf. p. 7.

${ }^{121} \mathrm{O}$ artigo 26 da Declaração e o objetivo de garantir a todos o acesso gratuito e universal, serve, desde 1948, como principio norteador do trabalho da UNESCO.
} 
educação e, mais recentemente, na implementação da EDH, que, conforme o desenvolvimento desta, continuará cumprindo o papel de principal procuradora dos direitos relativos à educação.

Sem embargo, outra agência especializada da ONU também deve ser mencionada: a UNICEF cumpre importante papel para a EDH, apesar de certamente mais limitado que a UNESCO.

A UNICEF também considera o inicio dos esforços substanciais programados em EDH por meio de seus programas e atividades somente a partir da década de 1990. Sem embargo, seus louros impulsionaram decisivamente o direito à educação e, consequentemente, à EDH. Diferentemente da UNESCO, a UNICEF não tem como objetivo principal a educação. Tem, sim, por objeto, a criança e todos os aspectos relacionados à necessidade dela, incluindo-se as necessidades primarias como a alimentação, a saúde, a segurança, etc. Desde sua criação, em 1946, a UNICEF trabalha próxima aos governos para influenciar as políticas e programas oficiais relacionados ao bem-estar das crianças, dentre eles, os educacionais. Além disso, a UNICEF promove os direitos da criança em nível universal estimulando a positivação deles no ordenamento internacional como parte do DIDH.

Assim foi com o direito à educação: a combinação dos esforços da UNICEF com outros diversos atores, incluindo a UNESCO, resultou no avanço das normativas relativas à educação. A realização de diversos eventos influenciaram este cenário, notadamente modificado pela adoção da Convenção Internacional dos Direitos da Criança, em 1989. No ano seguinte, esforços interagenciais levaram à organização da Conferencia Mundial de Educação para Todos, donde depreende-se a Declaração de Jomtien. A partir deste momento, a UNICEF passou a desempenhar importante papel na assistência aos Estadosmembros para alcançar o objetivo da educação para todos, incluindo-se aí a EDH.

A UNICEF desenvolve seu trabalho através de programas ${ }^{122}$ em parceria com os governos e normalmente com a assistência de ONGs internacionais, e incluem a qualificação dos professores e o relacionamento com os atores responsáveis pela educação. Obviamente, o objeto da UNICEF é a criança, de maneira que sua modalidade de EDH é

\footnotetext{
${ }^{122}$ In Burundi, UNICEF has supported and promoted the project "Strengthening education programs for orphans and vulnerable children" initiated by CARE USA, an NGO active in the field of humanitarian issues and fighting global poverty. Among the overall goals of this project is to improve the quality and relevance of education offered to orphan and vulnerable children as well as to improve gender equity by addressee. Do questionário respondido por esta Agencia ao questionários submetidos pelo Comitê Consultivo.
} 
restrita a este publico, sem embargo, ela desenvolve seu trabalho através de uma visão integrada que envolve outros elementos da $\mathrm{EDH}$, dada sua complexidade.

\begin{abstract}
The purpose is not simply to get children into school. It is also to support quality in terms of providing a safe and protective environment that is child-centered, child friendly and empowering through which the children can achieve the prescribed learning that equips them for life in their own communities as well as for participating and competing in life beyond their immediate communities.
\end{abstract}

Dessa maneira, a UNICEF acaba também por influenciar outras politicas publicas ligadas direta ou indiretamente à educação infantil e agora sob influencia direta da ideia da EDH.

\title{
1.4.2. A Declaração de Jomtien, de 1990
}

A Conferencia Mundial de Educação para Todos foi realizada em março de 1990 nesta cidade tailandesa. Como vimos, o propósito principal era o de avançar na efetivação do direito à educação conforme propugnados na DUDH, no PIDESC e em outros instrumentos internacionais. O resultado desta Conferencia está relatado na Declaração de Jomtien, que, sobretudo, afirma o direito à educação para todos, e desta, o Programa Mundial Educação para Todos, com vistas a atingir a educação básica para todas as crianças, jovens e adultos. Para isso, busca uniformizar as visões sobre a educação básica para alcançar a universalização do acesso, promovendo a igualdade, principalmente de gênero, posto que a opressão contra a mulher tem como um dos seus métodos a falta de acesso à educação.

A Declaração de Jomtien defende também que esforços devem ser empregados pelos governos - em parceria com as organizações internacionais - para alargar o escopo e os meios da educação básica, focando no aprendizado ${ }^{123}$. Ela recorda que havia mais de quarenta anos, a DUDH afirmava que todos tem o direito à educação. No entanto, em 1990, (i) mais de 100 milhões de crianças, incluindo, pelo menos, 60 milhões de meninas, não tinham acesso à escola primaria; (ii) mais de 960 milhões de adultos - destes, dois terços são mulheres - são analfabetos plenos ou funcionais sendo um grande problema em ambos países industrializados e em desenvolvimento; (iii) mais de um terço dos adultos no mundo não tem acesso ao conhecimento impresso ou às novas tecnologias que poderiam melhorar sua condição de vida; (iv) mais de 100 milhões de crianças e incontáveis adultos falham em completar a educação básica - milhões cumprem a frequência mas sem que

\footnotetext{
${ }^{123}$ Em seu artigo $6^{\circ}$, ela ressalta a importância do ambiente de aprendizado e ensino, por exemplo.
} 
adquiram conhecimento e habilidades.

Ela afirma que a educação para todos é fundamental para combater problemas atuais (em 1990) na sociedade internacional como: (i) a crise monetária que afetava o mundo; (ii) o aumento desproporcional das populações; (iii) o aumento das disparidades sociais dentro das nações; (iv) a guerra; ocupações; violência; criminalidade e (v) a morte evitável de milhões de crianças. Sem embargo, estes problemas foram obstáculos para o desenvolvimento e melhora da educação básica, especialmente em países menos desenvolvidos economicamente e, não obstante, em alguns países cujo o desempenho econômico foi favorável, muitos ainda continuam condenados à pobreza e ao analfabetismo. Por fim, observa que mesmo em países desenvolvidos houve um corte nos investimentos em educação durante a década de oitenta, como forma de equilibrar as contas públicas.

Desse modo, a Declaração de Jomtien foi decisiva na luta pelo acesso à educação universal em todo o mundo, concentrando esforços internacionais para a realização deste direito em nível nacional, que é onde a educação se desenvolve predominantemente. Este movimento é acompanhado pela evolução da $\mathrm{EDH}$, conforme o já afirmado e reiterado.

O Programa Mundial de Educação para Todos, inspirou a ONU e desencadeou a fase dos programas mundiais educacionais, como a Década das Nações Unidas da Educação para o Desenvolvimento Sustentável e os programas mundiais de EDH.

\subsubsection{Década da Educação em Direitos Humanos (1995-2004)}

Pursuant to a suggestion of the World Conference, the United Nations General Assembly, in its resolution 49/184 of 23 December 1994, proclaimed the 10-year period beginning on 1 January 1995 the United Nations Decade for Human Rights Education, and welcomed the Plan of Action for the Decade contained in the report of the Secretary-General. ${ }^{124}$

Em 1994 a Assembleia Geral proclama a Década de Ensino em Direitos Humanos a abranger o período entre 1 de janeiro de 1995 e 31 de dezembro de 2004. Influenciada pelos diversos instrumentos de direitos humanos anteriores, esta iniciativa tem o propósito de difundir a EDH que define como "training, dissemination and information efforts aimed at the building of a universal culture of human rights through the imparting of knowledge and skills and the moulding of attitudes." Tal propósito será atendido por meio: (i) do fortalecimento do respeito aos direitos humanos e liberdades fundamentais; (ii) do

${ }^{124}$ Resolução da Comissão de Direitos Humanos 2004/71. 
total desenvolvimento da personalidade humana no sentido de dignidade; (iii) da promoção da compreensão, tolerância e igualdade de gêneros e amizade entre as nações de todas as etnias, povos, religião, língua; (iv) da participação de todas as pessoas em uma sociedade livre e (v) do avanço das atividades da ONU para a manutenção da paz.

Como de praxe, o programa propõe um processo de coordenação para implementação de um Plano de Ação para a Década através do sistema da ONU, com cinco objetivos: (i) analisar as necessidades e formular estratégias; (ii) construir e fortalecer os programas de educação em direitos humanos em nível internacional, regional, nacional e local; (iii) desenvolver e coordenar a produção de material didático sobre a EDH; (iv) fortalecer o papel da mídia de massa e (v) promover a disseminação da DUDH.

O foco deste plano é estimular e apoiar iniciativas em nível nacional e local através de parcerias com os governos, organizações intergovernamentais, ONGs, associações profissionais e indivíduos. Em nível nacional, deve-se convocar os Estados-partes da ONU a criarem um comitê nacional de EDH com o objetivo de congregar uma coalizão dos atores governamentais e não-governamentais com a responsabilidade de desenvolver e implementar um amplo, efetivo e sustentável plano de longo prazo para a EDH. ${ }^{125}$ Tal programa teria os seguintes objetivos: (i) estabelecer um comitê nacional; (ii) conduzir um estudo prévio sobre as necessidades da EDH locais; (iii) estabelecer prioridades e identificar grupos vulneráveis; (iv) desenvolver o programa educacional; (v) implementalo e, por fim, (vi) avalia-lo em trabalho conjunto envolvendo os governos, os doadores e os programas internacionais.

Os programas nacionais devem ainda envolver todos os níveis da sociedade, através da provisão de educação formal e não-formal, educação especializada e programas feitos sob medida para grupos vulneráveis, grupos profissionais, etc., adequando para tanto, as modalidades e ferramentas mais pertinentes.

Assim sendo, os programas nacionais de EDH devem ser direcionados para: (i) o público em geral, em todos os níveis, para educar sobre os seus direitos; (ii) os grupos vulneráveis, incluindo mulheres, crianças, pessoas com deficiência, idosos, minorias, refugiados, povos indígenas, os pobres, pessoas com SIDA, etc., e (iii) a polícia e os agentes de segurança e da ordem.

\footnotetext{
${ }^{125}$ Neste sentido, Cf in "Guidelines for National Plans of Action for Human Rights Education” (UN Doc. A/52/469/Add.1 and Add.1/Corr.1). Disponível em http://www.ohchr.org/Documents/Publications/training10en.pdf. Acessado em 07.01.2011.
} 
O Plano de Ação também afirma a importância do papel desenvolvido pelos órgãos de tratados como veículo de implementação deles. Segundo ele, tais órgãos devem incluir provisões sobre a EDH e, através do contato direto com os Estados-partes, estimular o diálogo construtivo com os representantes dos governos.

O Programa, outrossim, chama a atenção dos órgãos de tratados para trabalhar mais proximamente à Comissão de Direitos Humanos, incorporando às suas provisões, as provisões emitidas por esta. Um documento foi, inclusive, preparado para orientar a participação deles no Plano de Ação da Década de Ensino em Direitos Humanos ${ }^{126}$. A ênfase dada ao papel dos referidos órgãos na EDH é justamente por terem eles a missão de fiscalizar as obrigações dos Estados perante o objeto ao qual se comprometem no tratado e, neste sentido, como vimos anteriormente, o direito à educação e mesmo o direito à EDH, estão presentes em diversos instrumentos internacionais, incluindo-se os tratados. Ademais, o Plano sugere ulteriormente o desenvolvimento dos comentários gerais e observações sobre estes direitos oriundos dos relatórios submetidos pelos estados partes. Os órgãos de tratados foram alimentados com este material no intuito de ampliar a observância do DEDH nos tratados já firmados, em cumprimento ao recomendado pela Convenção de Viena.

O Programa encerrou-se em 2004, momento no qual, os Estados concordaram em estende-lo até 2014, renovando a década de EDH que apresentou sucessos bem como fracassos. Como parte integrante da estratégia da Década, os governos foram instados a participar de todo o processo, inclusive da avaliação, seguindo um tendência da ONU.

Desta participação e no julgamento da Comissão de Direitos Humanos ${ }^{127}$, a Década obteve os seguintes êxitos: (i) fomentou atividades de EDH nos países que participaram ativamente do Programa, colocando "en el orden del día la cuestión de la educación en la esfera de los derechos humanos"; (ii) enquanto apenas cinco países constituíram comitês específicos, na maioria dos casos essa incumbência restou a cargo dos órgãos nacionais já existentes, como as INDHs, os ministérios, secretarias, etc., porém com relevante participação das ONGs; (iii) a criação de planos nacionais de EDH para atender aos propósitos da Década; (iv) a adoção de medidas legislativas em matéria de educação e a revisão do conteúdo do material didático com vistas a suprimir estereótipos e incluir os

\footnotetext{
${ }^{126}$ Resolução 52/127 de 12 dezembro de 1997.

${ }^{127}$ E/CN.4/2004/93 p. 7.
} 
princípios dos direitos humanos; (v) a Década influenciou atividades empreendidas em nível de ensino superior, com a preparação de cursos de direitos humanos, a criação de cátedras e institutos, etc.; (vi) muitos países apontam para o incremento da EDH dedicada aos agentes de ordem - policia, profissionais da justiça, em que pese raramente incluírem agentes carcerários; (vii) os Planos de Ação Nacionais demonstravam preocupação com a questão da educação intercultural e contra a discriminação e, finalmente, (viii) a participação dos organismos internacionais da ONU - por exemplo, a UNESCO, o Alto Comissariado das Nações Unidas para os Direitos Humanos (ACNUDH), o ACNUR, UNICEF, PNUD - como também outras organizações - como o Comitê Internacional da Cruz Vermelha (CICV) e o Conselho da Europa - na formulação de desenvolvimento dos Planos Nacionais.

Por outro lado, os insucessos da Década apontados pela Comissão de Direitos Humanos e fundamentais para que novas estratégias fossem adotadas, levando em consideração os erros cometidos, foram: (i) alguns governos indicaram que o contexto politico internacional e nacional fazem que a EDH seja uma prioridade a longo prazo, não sendo possível cumprir em apenas uma década; (ii) a diversidade cultural é novamente apontada como obstáculo para a EDH. Para contornar isso, deve-se aprofundar o conhecimento a respeito de culturas e civilizações distintas. O processo de mundialização traz incredibilidade e desconfiança que são terreno fértil para os fundamentalismos e extremismos, prosperando o terrorismo e a intolerância; (iii) a ausência de maior atenção do programa da Década aos direitos econômicos, sociais e culturais; (iv) o uso de metodologias aplicadas para fazer a EDH na vida cotidiana das pessoas; (v) a falta de sinergia entre juristas e pedagogos - o mesmo entre governos e ONGs; (vi) a ausência de monitoramento das ações tomadas pelos governos nacionais em relação à EDH; e, principalmente, (vii) a falta de recursos humanos e financeiros para os projetos de EDH devido a falta de vontade política dos governantes.

$\mathrm{Na}$ maioria das manifestações dos governos há indicativos do que eles mais carecem e, portanto, como a ONU poderia auxiliar na implementação dos seus programas em EDH. São eles: (i) a recompilação e divulgação de boas práticas em diversos setores; (ii) o apoio ao estabelecimento de redes nacionais e regionais de especialistas com a organização de intercambio de estudos e (iii) a preparação, adaptação ou tradução de material educativo. 


\subsubsection{Programa Mundial para a Educação em Direitos Humanos}

Em janeiro de 2005, finda a Década de Ensino em Direitos humanos, a ONU, além de decidir renova-la, lança nova investida na EDH através do Programa Mundial de Educação em Direitos Humanos - adotado em 10 de dezembro de $2004^{128}$ - com o objetivo de promover a EDH através de serviços de consultoria e assistência técnica e capacitação, definidos como uma das preocupações principais do Conselho de Direitos Humanos. ${ }^{129}$

Diferentemente da Década, o Programa Mundial de Educação não determina sua conclusão, mas se apresenta como um projeto permanente divido em fases consecutivas com objetivos e prazos determinados.

A primeira fase ${ }^{130}(2005-2009)$ foca o ensino primário e secundário (ou elementar e fundamental como os chamamos agora) sendo o Plano de Ação desenhado por especialistas em EDH dos cinco continentes, implementando um enfoque da educação com base nos direitos - seguindo o Rights Based Approach. O Plano prevê ações a serem tomadas pelos Estados-partes, em parceria com os outros atores internacionais, para implantar ou incrementar a EDH em seus sistemas educacionais primários e secundários. O plano define a EDH como

(...) um conjunto de atividades de educação, de capacitação e de difusão de
informação, orientadas para criar uma cultura universal de direitos humanos.
Uma educação integral em direitos humanos não somente proporciona
conhecimentos sobre os direitos humanos e os mecanismos para protegê-los, mas
que, além disso, transmite as aptidões necessárias para promover, defender e
aplicar os direitos humanos na vida cotidiana. A educação em direitos humanos
promove as atitudes e o comportamento necessários para que os direitos
humanos de todos os membros da sociedade sejam respeitados

O Plano de Ação para este programa define que a tendência na internacionalização da EDH "ilustra que existe consenso em que os sistemas de ensino desempenham uma função essencial na promoção do respeito, da participação, da igualdade e da nãodiscriminação nas nossas sociedades". E para tanto, "é necessário adotar um enfoque global para proporcionar a educação em direitos humanos, abordando não somente as políticas, processos e instrumentos educativos, mas também o ambiente em que essa educação é proporcionada."132

\footnotetext{
${ }^{128}$ Resolução 59/113 de 10 de dezembro de 2004..

${ }^{129}$ Resolução da Assembleia Geral 60/251.

${ }^{130}$ Em conformidade com o disposto na resolução 2004/71 da Comissão de Direitos Humanos, a primeira etapa (2005-2007) do Programa Mundial para a educação em direitos humanos será centrada nos sistemas de ensino primário e secundário. Conforme documento da Assembleia Geral A/59/525/Rev.1.

${ }^{131}$ Cf Plano de Ação do Programa Mundial de Educação em Direitos Humanos..

132 Ibid., prefacio.
} 
Como metas especificas para levar a EDH aos ensinos elementar e fundamental, o Plano de Ação, em sua primeira fase, elenca: (i) apoiar à elaboração ou o aperfeiçoamento, a adoção e aplicação de estratégias locais de EDH que sejam gerais, eficazes e sustentáveis; (ii) determinar as diretrizes para a EDH no sistema de ensino; e (iii) estabelecer a cooperação entre as organizações locais, nacionais, regionais e internacionais. Com estes elementos, buscar-se-á: (i) a criação de politicas públicas que incentivem a $\mathrm{EDH}$; (ii) o incremento do ambiente de aprendizagem e (iii) a formação dos docentes em EDH.

Ao final da primeira fase, o programa mundial foi avaliado em conjunto com os Estados-partes. Este processo de avaliação é muito importante para a EDH sendo, atualmente, considerado como elemento imprescindível para um bom programa nesta área.

A maioria dos Estados-membros confirmaram que, em geral, neste momento estão executando programas de EDH. O Plano de Ação deu forte impulso no movimento nacional pela EDH especialmente pelo reportado pela Argélia, Jordânia e Venezuela. Alguns países foram mais veementes nas ações, como é o caso da Costa do Marfim que reportou haver realizado um seminário para apresentar oficialmente as atividades a serem empregadas na promoção da EDH, em cumprimento ao sugerido no Plano de Ação. Nesta mesma esteira, o Plano foi exposto no sitio da internet do Ministério da Educação grego. Outros países, porém, informam que suas atividades no tocante à EDH não foram motivadas pelo Programa Mundial mas são desenvolvidas de maneira independente. Críticas apontam à falta de políticas específicas e estratégias de aplicação detalhadas sobre a EDH e a falta de enfoques sistemáticos na produção de material didático. A descentralização do sistema educacional em alguns países também foi indicados como obstáculos para a implantação de um plano geral.

Assim, o Comitê Coordenador, responsável por formular recomendações aos governos que desejem adotar novas medidas para alavancar a EDH no sistema escolar, determina os passos a serem seguidos, sendo eles: (i) fazer um balanço dos progressos nacionais em respeito à orientação pormenorizada que figura no Plano de Ação a fim de determinar as deficiências, as possíveis estratégias e as boas práticas; (ii) examinar as seguintes condicionantes: (a) fazer uma análise do estado da EDH nos sistemas de ensino primário e secundário para a elaboração de uma estratégia precisa; (b) elaborar uma estratégia de aplicação ampla; (c) a criação de compromissos normativos em matéria de EDH incluindo uma política pública de qualificação dos professores, com a inserção da 
EDH nos programas de formação destes e atenção orçamentaria dirigida para a implantação desta política; (d) difundir o material de EDH produzido pelas instituições e organizações nacionais, regionais e internacionais dentro ou fora do contexto do Programa Mundial, em particular as plataformas de tecnologia da informação, como uma forma de abordar os problemas de recursos em nível nacional, como a falta de financiamento, educação e materiais didáticos, assim como materiais destinados à formação docente, inspirados nas práticas bem-sucedidas de outros países; (e) adotar medidas para que os provedores de ensino privado também integrem a EDH nos seus serviços e, finalmente, (f) participar em iniciativas internacionais e regionais relativas à elaboração de políticas e programas em âmbito da EDH.

Concluída a primeira fase com o processo de avaliação, tem inicio a segunda fase do Programa Mundial de Educação em Direitos Humanos, que abrangerá o período de 2010 e $2014^{133}$ e será concentrada em novos setores que devem ser permeados com a EDH, como a educação superior, os professores e educadores, os funcionários públicos, os funcionários encarregados de fazer cumprir a lei e os militares.

Primeiramente, vale ressaltar que os esforços para o trabalho de introduzir efetivamente a EDH nas escolas primaria e secundarias - como propõe a Primeira fase do Programa - não podem ser dispensados ou desatendidos por se iniciar nova fase. A EDH é um processo permanente, conclusão que os programas mundiais levaram à comunidade internacional.

Os objetivos concretos da segunda fase (2010-2014) são: (i) promover a inclusão da EDH no ensino superior e nos programas de formação para funcionários públicos, forças de ordem e militares; (ii) apoiar a elaboração, adoção e aplicação de estratégias nacionais sustentáveis para a EDH; (iii) proporcionar diretrizes sobre componentes decisivos da EDH no ensino superior e nos programas de formação para os servidores públicos mencionados; (iv) facilitar a prestação de apoio pelas organizações internacionais, regionais, nacionais e locais às instituições de educação superior dos Estados-membros; (v) apoiar o estabelecimento de redes de contato e a cooperação entre as instituições e

\footnotetext{
133 "Según la resolución 12/4 del Consejo de Derechos Humanos, la segunda etapa del Programa Mundial (2010-2014) se centrará en "la educación en derechos humanos en la enseñanza superior y en los programas de capacitación sobre derechos humanos para maestros y educadores, funcionarios públicos, fuerzas del orden y personal militar a todos los niveles" y "los Estados miembros deben seguir impartiendo educación en materia de derechos humanos en la enseñanza primaria y secundaria". Plano de Ação do Programa Mundial de Educação em Direitos Humanos.
} 
organizações locais, nacionais, regionais e internacionais tanto governamentais como as ONGs.

Por se tratar de programa recente e ainda em andamento, não dispomos de elementos para avalia-lo. Sem embargo, o Programa de Educação em Direitos Humanos demonstrou claramente uma dificuldade: o processo de evolução da EDH fragmentada como propõe o Programa, não se mostra efetiva conforme o planejado devido sua própria falta de continuidade. Apesar dos avanços da primeira fase, não se pode, de maneira alguma, dizer que o objetivo foi alcançado e resta difícil garantir que os governos continuarão os esforços para o seu adimplemento uma vez que têm novo desafio proposto pela segunda fase. Lembremos que o campo da EDH carece de profissionais especializados, como, sobretudo, de investimentos financeiros.

A necessidade de avançar a EDH, por ser ela o remédio que pode faltar para curar as enfermidades das sociedades atuais, pressiona o sistema da ONU a empregar ainda mais esforços para a satisfação destes objetivos. Em comemoração aos 60 anos da DUDH, a ONU decide, através da Resolução 62/171, decretar 2008 o Ano Internacional de Educação em Direitos Humanos com vistas a dedicar atividades com o objetivo de ampliar e aprofundar a aprendizagem sobre os direitos humanos, objetivando reforçar a promoção e proteção dos direitos humanos e as liberdades. Nas palavras da Alta Comissária da ONU para os Direitos Humanos, Navanethem (Navi) Pillay:

\begin{abstract}
"Dezenas de milhões de pessoas por todo o mundo ainda não estão conscientes de que têm direitos que podem exigir, e que os seus governos são responsáveis por eles, e por um amplo conjunto de direitos com a legislação nacional e internacional. Apesar de todos os nossos esforços nos últimos 60 anos, este aniversário vai passar por muitas pessoas, e é essencial manter o ritmo, permitindo assim que mais e mais pessoas se levantem e reivindiquem os seus direitos. Por esta razão, congratulo-me sinceramente pelo fato de que o próximo ano, foi designado como o Ano Internacional da Aprendizagem dos Direitos Humanos. E gostaria de incentivar os ministérios, instituições, professores, pais e outras pessoas em posição de responsabilidade em todo o planeta, para aproveitar esta oportunidade para assegurar que a próxima geração é dada a oportunidade máxima para reivindicar o que foi prometido a eles nesse documento extraordinário conhecida como a Declaração Universal dos Direitos Humanos."
\end{abstract}

Desse modo, a ONU vem tomando seguidas medidas para avançar na EDH como uma de suas prioridades. O resultado de todas as iniciativas, em especial, a Década de EDH e o Programa Mundial, revelou a necessidade de tomar uma medida mais abrangente capaz de chamar a atenção definitiva ao tema e traçar um plano permanente e consolidado em EDH. Daí a decisão pela elaboração da DEFDH, resultado também de outros diversos processos paralelos, que passamos a analisar em seguida. 


\section{Capítulo 2}

\section{A Declaração das nações unidas sobre a educação e formação em direitos humanos: retórica.}

\subsection{Do Conselho de Direitos Humanos e seu comitê consultivo}

Conforme visto inicialmente, a ONU está baseada no tripé Segurança, Desenvolvimento e Direitos Humanos. No entanto, em 1945, enquanto os dois primeiros temas foram entregues a cargo do Conselho de Segurança e do ECOSOC, respectivamente, o tema dos direitos humanos era tratado de maneira secundária, como uma das atribuições do ECOSOC, através da extinta Comissão de Direitos Humanos ${ }^{134}$ que era subsidiária a ele.

Conforme observado, o processo histórico do aumento da importância dos direitos humanos em âmbito internacional é impulsionado de maneira especial a partir da Convenção de Viena, em 1993, que modificou a atenção dada aos direitos humanos dentro do sistema ONU. Imediatamente, lembramos a recomendação da Convenção - prontamente acolhida - pela criação, em 1993, do posto de Alto Comissário para os direitos humanos, exercido pelo brasileiro Sérgio Vieira de Mello no período entre 2002 e 2003. Os eventos subsequentes - por exemplo, os atentados às Torres Gêmeas (2001), a ocupação do Iraque pelos EUA (2003), os conflitos na África, etc. - trouxeram a sensação de se estar perdendo a luta pela promoção e proteção dos direitos humanos. Em verdade os desmandos estadunidenses colocaram em xeque a própria $\mathrm{ONU}^{135}$. Todos esses fatores levaram as nações mais uma vez a se reunir para planejar um novo horizonte para a sociedade internacional e este movimento culmina na criação do Conselho de Direitos Humanos.

O Conselho de Direitos Humanos foi criado pela Assembleia Geral ${ }^{136}$, em 15 de março de 2006, em substituição à extinta Comissão de Direitos Humanos. O principal motivo para a extinção da Comissão e a criação do Conselho foi justamente dar enfoque maior à temática dos direitos humanos em sua proteção e promoção e assim balancear o tripé no qual a ONU está sustentada. O Conselho trouxe mais atenção aos direitos humanos, elevou sua importância na esfera política internacional, na atenção a eles e no

\footnotetext{
${ }^{134}$ A este respeito ver: resolução 5/1 de 1946 do Conselho Econômico e Social e artigo 68 da Carta das Nações.

${ }^{135}$ Os EUA contrariaram o decisão do Conselho de Segurança sobre a intervenção militar no Iraque.

${ }^{136}$ Resolução A/RES/60/251.
} 
modus operandi de sua promoção e proteção.

Em março de 2006, após 60 anos, a Comissão de Direitos Humanos realizou a sua última sessão de trabalho. A história deste extinto órgão é marcada por críticas, basicamente pelo excesso de politização nas suas decisões e pela presença de membros cujo histórico de direitos humanos não eram condizentes com a função. O insucesso da Comissão influenciou diretamente a reforma da própria ONU e suas diretrizes de trabalho. Neste sentido, vale observar a posição estadunidense de que a criação do Conselho não mudaria o cenário apresentado quando da Comissão, a não ser que critérios para a eleição de novos membros fossem estabelecidos com base no histórico de direitos humanos dos Estados candidatos - muitos países buscavam mandatos na Comissão ou para protegeremse de acusações de condutas contrárias aos direitos humanos, ou, simplesmente, para criticar outros países ${ }^{137}$. Em que pese o próprio histórico dos EUA em matéria dos direitos humanos.

O Conselho surge para revitalizar a atuação da ONU no tocante aos direitos humanos. O referido órgão atende também a uma demanda - principalmente das ONGs por maior participação na formulação da ordem internacional dedicada aos direitos humanos, e, sobretudo, com o objetivo máximo de avaliar violações dos direitos humanos e elaborar recomendações a respeito, objetivando estabelecer uma cultura de direitos humanos para a comunidade internacional.

Prova da maior atenção dedicada ao tema dos direitos humanos com a criação do Conselho de Direitos Humanos é que, como mencionado anteriormente, este se submete diretamente à Assembleia Geral, que também se encarregada da eleição dos seus membros. Os 47 países que compõem o Conselho são eleitos em votação secreta, atendendo à seguinte distribuição geográfica: 13 lugares para o continente africano, 13 lugares para o asiático, 6 para a Europa oriental, 8 para a América latina, Caribe e Europa ocidental e outros com 6 cadeiras. O mandato é de 3 anos, podendo haver apenas uma reeleição consecutiva.

A fim de evitar a politização ou o uso indevido de uma cadeira no Conselho, foi dada à Assembleia Geral a possibilidade de suspender um Estado-membro se comprovadas acusações de graves violações em seu território, o que minimiza o problema, mas não o resolve, já que prevê a possibilidade em casos extremos. Por outro lado, caso admitisse

${ }^{137} \mathrm{~A} / 59 / 2005, \S 182$. 
apenas países com histórico "puro" de direitos humanos, muito provavelmente suas cadeiras estariam ou vazias ou preenchidas apenas pelos países mais poderosos ${ }^{138}$.

Após um ano da sua primeira reunião, o Conselho adota seu Institution building package $^{139}$ - documento que traz os elementos que instruirão os trabalhos deste órgão. Quanto aos seus mecanismos, o Conselho, além de manter os procedimentos especiais e os procedimentos de denúncia criados à época da Comissão, inovou com a adoção de novos mecanismos de promoção, monitoramento e proteção dos direitos humanos, notadamente o exame periódico universal e a criação do Comitê Consultivo.

Chamam-se procedimentos especiais, os mecanismos utilizados pelo Conselho de Direitos Humanos para tratar de problemas temáticos em todo o mundo ou situações de graves violações sistemáticas em países específicos. Atualmente, há 33 mandatos temáticos (com temas variados como o direito à moradia, a detenção arbitrária, a pobreza extrema, povos indígenas, etc.) e 8 mandatos sobre países especificamente (atualmente Burundi, Camboja, Coréia do Norte, Haiti, Birmânia, Palestina, Somália e Sudão).

O ACNUDH provem apoio de equipe e logístico ao Conselho para esta tarefa. Os mandatos - que são criados através de resoluções - outorgam competência para o Conselho examinar, monitorar, orientar e publicar relatórios sobre a situação dos direitos humanos em países ou territórios específicos onde ocorrerem violações graves e sistemáticas de direitos humanos.

A execução dos procedimentos especiais pode estar a cargo de um individuo ${ }^{140}$ a serviço da ONU ou de um grupo de trabalho normalmente composto por cinco membros representando as cinco regiões do globo que, na maioria das vezes, recebem informações sobre alegações específicas de violações de direitos humanos e enviam apelos urgentes e cartas de alegação para os governos pedindo esclarecimento. Em 2010, 604 comunicações foram enviadas a governos de 110 países. Em um segundo momento, os mandatários dos procedimentos especiais visitam o país onde as violações estão ocorrendo para investigar a situação dos direitos humanos em nível nacional.

Com o advento do Conselho dos Direitos Humanos, uma plena revisão de todos os mandatos ocorreu no período de 2007-2008.

\footnotetext{
${ }^{138}$ Não por terem eles históricos limpos de direitos humanos.

${ }^{139} \mathrm{~A} / \mathrm{HRC} / \mathrm{RES} / 5 / 1$. Institution-building of the United Nations Human Rights Council. Publicado em 18 Junho de 2007.

${ }^{140}$ Nas figuras do Special rapporteur, Special representative of the Secretary-General ou Independent Expert.
} 
Do mesmo modo, o mecanismo de denúncia - criado pela extinta Comissão de Direitos Humanos - foi mantido pelo Conselho ${ }^{141}$, como não poderia deixar de ser, já que, na verdade, esta era a característica ou instrumento mais marcante do extinto órgão.

Em linhas gerais, o mecanismo de denúncia é a possibilidade de violações graves de direitos humanos ocorridas em um Estado serem levadas ao conhecimento da comunidade internacional para providências. Para que um novo procedimento de denúncia seja criado é necessário que sejam cumpridos certos requisitos que garantam que o procedimento será executado de maneira imparcial, objetiva, eficiente, orientada para as vítimas e conduzida dentro de um cronograma razoável ${ }^{142}$.

A grosso modo, uma denúncia é admissível junto ao Conselho de direitos humanos quando: (i) não for anônima; (ii) não contiver manifestadamente motivação política e o objeto for pertinente à Carta da ONU; (iii) houver descrição fatual das violações alegadas informando que direitos humanos foram violados; (iv) sua linguagem não for abusiva ${ }^{143}$; (v) for submetida pela pessoa ou grupo de pessoas que tiveram seus direitos humanos violados ou por qualquer pessoa ou grupo de pessoas e organizações não-governamentais agindo de boa fé; (vi) quando não for exclusivamente baseado em relatos disseminados pela mídia de massa; (vii) não se referir a um caso que já tenha sido tratado por um procedimento especial, órgão de tratado ou outro sistema de denúncia regional similar da ONU e (viii) os recursos domésticos já tenham sido esgotados, exceto no caso destes recursos forem inefetivos ou injustificavelmente procrastinados.

Por seu turno, o exame periódico universal ${ }^{144}$ é o mecanismo principal de monitoramento global dos direitos humanos nos 192 países membros da ONU e a maior inovação trazida pela criação do Conselho de Direitos Humanos. A cada quatro anos, os Estados-partes devem enviar um relatório dirigido ao Conselho de Direitos Humanos relatando a situação destes em seu território e as ações tomadas para o cumprimento dos compromissos assumidos internacionalmente, em termos de direitos humanos. Em teoria, é o momento em que todos os Estados-partes são examinados - em condições de igualdade quanto à situação dos direitos humanos em seus territórios. Como foi criado em 2006 e, tendo sido colocado em prática em 2007, é dizer que, até 2011, todos os países do mundo

\footnotetext{
${ }^{141}$ Resolução 60/251 de 15 de março de 2006.

${ }^{142}$ Para mais informações sobre o procedimento de denuncia, $\mathrm{Cf}$ as resoluções A/HRC/3/CRP.3, A/HRC/4/CRP.6 e A/HRC/5/CRP.6.

${ }^{143}$ No entanto em casos especiais a denúncia poderá ser aceita sendo para tanto suprimido os termos agressivos ou ofensivos.

${ }^{144}$ Resolução 60/251 da Assembleia Geral que também criou o Conselho de Direitos Humanos.
} 
terão sua situação atual de direitos humanos analisada pelo Conselho.

Além de obrigar os Estados a reportarem a situação de direitos humanos em sua jurisdição, ou seja, a função de monitorar, o exame periódico universal eleva a importância dos direitos humanos dentro das agendas políticas nacionais.

Interessante sobre este mecanismo é a possibilidade de emissão de relatóriossombra ${ }^{145}$ oriundos da sociedade civil, do contrário, restaria ao Conselho conformar-se em receber relatórios pomposos que atenderiam mais a anseios políticos domésticos de seus governantes, que documentos que demonstrem realmente uma reunião de esforços dedicados à promoção e proteção dos direitos humanos. O relatório-sombra é um instrumento de fiscalização da prestação de contas de um Estado em esfera internacional. Ele é fundamental para uma relação interestatal chamada em inglês Blame and shame ${ }^{146}$, afinal, a revelação de violações de direitos humanos não é capital político interessante em esfera internacional.

Finalmente, a última inovação - e a que mais interessa a esta pesquisa - foi a criação do Comitê Consultivo em substituição à Subcomissão de Promoção e Proteção dos Direitos Humanos ${ }^{147}$.

O Comitê Consultivo funciona como provedor de conhecimento técnico em matéria de estudos de direitos humanos. Ele não adota resoluções nem toma decisões, podendo operar tão somente quando acionado pelo Conselho de Direitos Humanos. Seus 18 especialistas $^{148}$ são nomeados, atendendo a um critério técnico e objetivo ${ }^{149}$, que busca, basicamente, garantir que o mais alto nível de conhecimento seja alcançado.

Seu trabalhado é desenvolvido principalmente através de estudos e orientações baseados em pesquisa e pareceres emitidos que devem atender exatamente ao pedido do Conselho e limitar-se ao próprio escopo deste - isto é, a promoção e proteção dos direitos humanos -, em interação com os Estados, as INDHs, as ONGs e outras entidades da sociedade civil. Estas organizações estão agora aptas a participarem diretamente do

\footnotetext{
145 Tradução do autor para Shadow Reports.

${ }^{146}$ Em tradução do autor: "Culpar e envergonhar."

${ }^{147}$ Órgão subsidiário da Comissão de Direitos Humanos.

148 A respeito da eleição dos membros do Comitê e sua atual composição Cf. http://www2.ohchr.org/english/bodies/hrcouncil/advisorycommittee/docs/A.HRC.16.19_sp.pdf.

149 contido na Decisão do Conselho 6/102. Disponível en inglês em http://www2.ohchr.org/english/bodies/hrcouncil/advisorycommittee.htm. Acessado 07.01.2012.
} 
trabalho do Comitê Consultivo ${ }^{150}$.

O Comitê reúne-se em duas sessões de até dez dias ao ano e teve sua sessão inaugural de 4 a 15 de agosto de 2008. Importante notar que, quando da formação do Comitê Consultivo, já havia em fila o pedido para a elaboração de recomendações sobre os temas do direito à moradia ${ }^{151}$, das pessoas desaparecidas ${ }^{152}$, da discriminação contra pessoas com hanseníase e seus familiares ${ }^{153}$, entre outras, e de um esboço de uma declaração sobre educação e formação em direitos humanos, uma vez que a Resolução 6/10 - que requer o projeto de declaração - data de 8 de novembro de 2.007 .

Quando assume a tarefa de dar continuidade à elaboração do anteprojeto de DEFDH, o Comitê, inicialmente, decide criar um grupo de redação entre seus membros, incumbido de reunir os elementos a contar num anteprojeto de declaração. Os seguintes membros foram designados: Emmanuel Decaux ${ }^{154}$, Héctor Felipe Fix Fierro ${ }^{155}$, Vladimir Kartashkin ${ }^{156}$, Purificación V. Quisumbing ${ }^{157}$ e Halima Embarek Warzari ${ }^{158}$. Esta foi eleita pelo próprio grupo de redação sua presidenta enquanto Emmanuel Decaux foi eleito seu relator e como tal, o responsável pela elaboração das diretrizes e os procedimentos para viabilizar o processo de participação.

Durante a sua $10^{\text {a }}$ sessão regular, o Conselho recebe com satisfação o progresso do trabalho realizado pelo Comitê neste período e, desta feita, requer elaboração do anteprojeto da Declaração, consultando os órgãos pertinentes à participação neste

\footnotetext{
${ }^{150}$ based on arrangements, including Economic and Social Council resolution 1996/31 and practices observed by the Commission on Human Rights and the Council, while ensuring the most effective contribution of these entities.

${ }^{151}$ Cf Resolução 7/14. Disponível em espanhol em http://www.cetim.ch/es/documents/codh-res-7-14-esp.pdf. Acessado em 07.01.2011.

${ }_{152}$ Cf $\quad$ Resolução $7 / 28$. Disponível $\quad$ em $\quad$ espanhol em http://ap.ohchr.org/documents/S/HRC/resolutions/A_HRC_RES_7_28.pdf. Acessado em 07.01.2011.

${ }^{153}$ Cf Resolução 8/13. Disponível em espanhol em http://www $2 . \bar{h}$ chr.org/english/bodies/hrcouncil/docs/A65-53-Add1_sp.pdf. Acessado em 07.01.2011.

${ }^{154}$ Francês, professor na Universidade Panthéon-Assas Paris II, Diretor do Centre de recherche sur les droits de l'homme et le droit humanitaire $(\mathrm{CRDH})$ da Universidade de Paris II e editor do Jornal Droits fondamentaux.

${ }^{155}$ Mexicano, professor, Diretor do Instituto de Investigaciones Legales, Universidad Nacional Autonoma de México.

${ }^{156}$ Russo, professor do Institute of State and Law of the Russian Academy of Sciences de Moscou.

${ }^{157}$ Filipino, representante do Philippine Judicial Academy (PHILJA) Committee on Gender Responsiveness in the Judiciary (CGRJ).

${ }_{158}$ Marroquina, professora, colaborou na redação dos seguintes instrumentos internacionais: PIDCP; PIDESC; Convenção sobre a eliminação de todas as formas de discriminação racial; Convenção sobre a eliminação de todas as formas de discriminação contra a mulher; Declaração contra a Intolerância Religiosa; Convenção dos Direitos da Criança; Convenção contra a tortura; Convenção sobre a Proteção aos Trabalhadores Migrantes e seus familiares e ainda participou ativamente da Conferencia Mundial dos Direitos Humanos de Viena, em 1993.
} 
processo, bem como dá boas-vindas à iniciativa da Plataforma pela $\mathrm{EDH}^{159}$ de realizar um seminário ${ }^{160}$ com a participação de todas as partes interessadas para aprofundar a reflexão sobre os elementos a serem incluídos no esboço da Declaração. ${ }^{161}$

\subsection{Razões da declaração e os procedimentos iniciais}

São muitos os motivos anunciados para mover o Conselho de Direitos Humanos na direção de requerer ao seu Comitê Consultivo a preparação de um esboço de uma declaração que trate do tema da EDH. Como tivemos a oportunidade de observar, o processo pela positivação do DEDH em documento especifico é resultado de todo o trabalho de difusão da DUDH desde sua adoção em 1948.

Quanto à burocracia, os procedimentos têm inicio com a Resolução 6/10 do Conselho de Direitos Humanos, de 08 de novembro de $2007^{162}$. Esta resolução tem por objeto o tema "Racismo, discriminação racial, xenofobia e formas conexas de intolerância. Trata-se do seguimento e aplicação da Declaração e o Programa de Ação de Durban”, que, por sua vez, são os documentos resultado da III Conferência Mundial de Combate ao Racismo, Discriminação Racial, Xenofobia e Intolerância Correlata ${ }^{163}$, realizada em $2001^{164}$, nesta cidade sul-africana, em cumprimento à convocação da extinta Comissão de Direitos Humanos ${ }^{165}$, da Assembleia Geral, como também ao recomendado na Declaração de Viena (1993) e seu Programa de Ação, que apontam para a necessidade de rápido e abrangente combate à discriminação racial e a xenofobia.

Em seguida à Declaração de Durban e seu Programa de Ação, a extinta Comissão de Direitos humanos criou o grupo de trabalho ${ }^{166}$ intergovernamental para que trabalhasse em recomendações para a efetiva implementação desta Declaração. Foram criados, na verdade,

\footnotetext{
${ }^{159}$ Cf p. 80.

${ }^{160}$ Cf p. 90 sobre o seminário.

${ }^{161}$ Conforme Resolução 10/28.

${ }^{162} \mathrm{~A} / \mathrm{HRC} / 6 / 10$.

${ }^{163}$ As duas primeiras conferencias mundiais de combate ao racismo e discriminação racial ocorreram em Genebra em 1978 e 1983.

${ }^{164} 2001$ foi o Ano Internacional de Mobilização contra o Racismo, Discriminação Racial, Xenofobia e Intolerância Correlata e o ano das Nações Unidas de Diálogo entre as Civilizações.

${ }^{165}$ Resolução 1997/74 da extinta Comissão de Direitos Humanos (substituída pelo Conselho de Direitos Humanos.

${ }^{166} \mathrm{O}$ grupo de trabalho intergovernamental foi estabelecido pela extinta Comissão de Direitos Humanos através da resolução 2002/68 e aprovada pelo Conselho Econômico e Social em sua decisão 2002/270, de 25 de julho de 2002. O grupo de trabalho é um open-ended grupo de trabalho, o que significa que todos os membros das Nações Unidas, organizações intergovernamentais, organizações não-governamentais com status consultivo junto ao Conselho Econômico e Social e as organizações não-governamentais que foram credenciadas para a Conferencia mundial contra o racismo, podem atender às reuniões públicas do grupo de trabalho.
} 
dois grupos de trabalho ${ }^{167}$. Um destes era o grupo de trabalho intergovernamental com o mandado de fazer recomendações para a implementação efetiva da Declaração de Durban e preparar estândares internacionais complementários para fortalecer e atualizar instrumentos internacionais contra o racismo, a discriminação racial, a xenofobia e intolerâncias correlatas, em todos os seus aspectos ${ }^{168}$.

A Declaração de Durban urge os Estados a combater "o flagelo do racismo, da discriminação racial, da xenofobia e da intolerância correlata que persiste e continua sendo causa de violações dos direitos humanos, sofrimentos, desvantagens e violência, que devem ser combatidos por todos os meios disponíveis e apropriados como questão de prioridade máxima, preferencialmente em cooperação com comunidades atingidas.”" 169

O problema racial continua a obstaculizar a satisfação dos direitos humanos de tal maneira que o seu pronto combate deve ser entendido como uma prioridade para a comunidade internacional que considerou a Conferencia de Durban uma "oportunidade impar e histórica para a avaliação e identificação de todas as dimensões destes males devastadores da humanidade visando sua total eliminação." ${ }^{170}$ Por entenderem que o racismo está enraizado na sociedade - sendo transmitido de gerações em gerações - os especialistas apontaram ferramentas para o combate seu combate, entre elas, a EDH.

Por esta razão, a EDH aparece nos parágrafos 25, 57, 61, 64, 70, 73, 76, 77, 92 do Informe del Grupo de Trabajo Intergubernamental sobre la Aplicación y el Programa de Acción de Durban sobre su quinto periodo de sesiones, parte integrante da Resolução 6/10.

Os especialistas deste grupo de trabalho concordaram que a EDH desempenha função crucial na luta contra o racismo e as formas conexas de intolerância ${ }^{171}$. Portanto, esforços devem ser empregados para a formulação de políticas de luta contra a discriminação, fazendo da EDH um elemento central e com a participação imprescindível

\footnotetext{
${ }^{167}$ Conforme Resolução 2002/68 da extinta Comissão de Direitos Humanos.

${ }^{168} \mathrm{O}$ outro grupo de trabalho era composto de 5 estudiosos independentes especialistas em afro descendência, com as seguintes missões: (a) estudar problemas de discriminação racial enfrentados por afrodescendentes vivendo em diáspora; (b) propor medidas para que afrodescendentes tenham pleno acesso a justiça; (c) recomendar a respeito do desenho, implementação, e aplicação de medidas para eliminar o estereótipo racial dos afrodescendentes; (d) propor mecanismo para monitorar e promover todos os direitos humanos, em estreita colaboração com instituições internacionais de desenvolvimento e agências especializadas da ONU. Conforme a/hrc/4/wg.3/6. Disponivel em inglês em http://www2.ohchr.org/english/issues/racism/groups/implementation-6th.htm. Acessado em 07.01.2011.

${ }^{169}$ Preâmbulo da Declaração de Durban.

${ }^{170}$ Declaração de Durban, loc. cit.

${ }^{171}$ Informe del Grupo de Trabajo Intergubernamental sobre la Aplicación y el Programa de Acción de Durban sobre su quinto periodo de sesiones, parte integrante da Resolução 6/10, § 61 .
} 
das entidades não estatais ${ }^{172}$. O $§ 57$ é o mais importante a este respeito ao afirmar que havia uma lacuna normativa a respeito da $\mathrm{EDH}$ em geral e que este poderia ser o momento para o preenchimento dela.

\begin{abstract}
"El Presidente explicó que el capítulo I contenía un análisis de las obligaciones positivas de los Estados Partes, con la conclusión de los expertos de que existía una laguna normativa en esa esfera. Los expertos habian terminado el capitulo con una recomendación de que se adoptara un instrumento vinculante y general en que se estableciera el deber de promover la no discriminación, la tolerancia y la igualdad de derechos, independientemente de cualesquiera consideraciones de raza, origen étnico y de otro tipo, por conducto de la educación en materia de derechos humanos."
\end{abstract}

Durante o debates deste grupo de trabalho, a proposta de elaboração de um instrumento internacional com a finalidade de preencher essa lacuna ganhou importância entre os especialistas que pediram clarificações sobre a recomendação para uma instrumento sobre a EDH, mais especificamente, sobre o possível conteúdo e qual o órgão que estaria a cargo da sua redação, se a UNESCO ou o Conselho de Direitos Humanos. ${ }^{173}$

Um delegado perguntou qual seria a melhor forma de avançar com a proposta de criar um documento internacional sobre a EDH para transcender o artigo $7^{\circ}$ da Convenção Internacional sobre a Eliminação de Todas as Formas de Discriminação Racial. ${ }^{174}$

Outro membro do grupo - professora Petrova - reiterou que

$$
\begin{aligned}
& \text { (...) existía una laguna en la educación sobre los derechos humanos, ya que no } \\
& \text { habia ningún documento jurídicamente vinculante que estableciera el deber de } \\
& \text { promover la no discriminación, la tolerancia y la igualdad de derechos } \\
& \text { independientemente de la raza, la etnia y otras consideraciones conexas } \\
& \text { mediante la educación en materia de derechos humanos. }
\end{aligned}
$$

Serguei Lazarev, da UNESCO, comentou sobre a disposição deste organismo de elaborar ou contribuir para a elaboração de um instrumento de direitos humanos sobre a educação para combater o racismo e informou que a experiência da UNESCO neste campo a credenciava para elaborar um instrumento dessa índole. ${ }^{175}$

De fato, a Declaração de Durban tem grande importância no construir dos direitos humanos, especialmente no tocante à $\mathrm{EDH}$, quando afirma que uma das causas da

\footnotetext{
${ }^{172}$ Informe del Grupo de Trabajo Intergubernamental sobre la Aplicación y el Programa de Acción de Durban sobre su quinto periodo de sesiones, parte integrante da Resolução 6/10, § 25.

${ }^{173}$ Ibid., § 64 .

${ }^{174}$ Ibid., $\$ 70$.

${ }^{175}$ Ibid., $\$ 71$.
} 
discriminação racial e xenofobia é a falta dela. ${ }^{176}$ Segundo a declaração, os Estados devem

(..) realizar e facilitar atividades que visem à educação de jovens em direitos humanos, à cidadania democrática e à introdução de valores de solidariedade, respeito e apreço à diversidade, incluindo o respeito por diferentes grupos. Um esforço especial para informar e sensibilizar os jovens para respeitarem os valores democráticos e os direitos humanos, devem ser realizados ou desenvolvidos para lutar contra ideologias baseadas na teoria falaciosa da superioridade racial. ${ }^{177}$

Finalmente, a Declaração, ao elencar as recomendações para os Estados para o combate à discriminação racial e xenofobia, inclui como elemento essencial a EDH, ao convocar os Estados a adotarem e implementarem, nacional e internacionalmente, medidas e politicas efetivas para o combate à discriminação, além das medidas legislativas já existentes, nacionais e internacionais, que "incentivam todos os cidadãos e instituições a tomarem posição contra o racismo, a discriminação racial, a xenofobia e a intolerância correlata e a reconhecerem, respeitarem e maximizarem os benefícios da diversidade, dentro e entre todas as nações." ${ }^{\prime 17}$ Para que esses objetivos sejam alcançados é necessária uma conjunção de esforços, “em particular através da informação pública e de programas educativos para aumentar a consciência e o entendimento dos benefícios da diversidade cultural.",179

Podemos concluir, portanto, que, além de todo o processo de construção histórica do direito humano à EDH que vimos analisando, o elemento que motivou, ao menos procedimentalmente, o pedido da Assembleia Geral por um anteprojeto de declaração sobre EDH foi a Declaração de Durban, em estratégias para o combate ao racismo, xenofobia e intolerâncias correlatas.

Assim, o Conselho de Direitos Humanos, dando sequencia à construção iniciada em 1945 com a Carta das Nações Unidas, atendendo propriamente a esta que incumbe a Assembleia Geral de elaborar estudos e recomendações destinados a promover a cooperação internacional no campo político e incentivar o desenvolvimento progressivo do

\footnotetext{
${ }^{176}$ Declaração de Durban, artigo 127: "Insta os Estados a intensificarem seus esforços no campo da educação, incluindo a educação em direitos humanos, a fim de promoverem o entendimento e a conscientização das causas, conseqüências e males do racismo, discriminação racial, xenofobia e intolerância correlata e, também, recomenda aos Estados e incentiva as autoridades educacionais e o setor privado a desenvolverem materiais didáticos, em consulta com autoridades educacionais e o setor público, incluindo, livros didáticos e dicionários, visando ao combate daqueles fenômenos; neste contexto, exorta os Estados a darem a importância necessária à revisão e à correção dos livros-textos e dos currículos para a eliminação de quaisquer elementos que venham a promover racismo, discriminação racial, xenofobia e intolerância correlata ou a reforçar estereótipos negativos, e para incluírem material que refute tais estereótipos.”

177 Ibid., art. 130.

${ }^{178}$ Ibid., art. 58.

${ }^{179}$ Declaração de Durban, loc. cit.
} 
Direito Internacional e sua codificação, como também promover a cooperação internacional em variados campos, entre eles, o educacional ${ }^{180}$, decidiu, em 2007, pela necessidade da elaboração de um instrumento internacional que tratasse exclusivamente do tema da EDH, sinalizando à comunidade internacional a importância fundamental dela para o aprimoramento da promoção e proteção dos direitos humanos.

O evento em Durban é considerado um grande sucesso apesar de, ao seu final, assistir à retirada dos EUA e de Israel ao fim da Conferencia causada por entendimentos inconciliáveis destes com os entendimentos dos países árabes muçulmanos. Nas palavras do chefe da missão israelense, Alan Baker, "no rational argument has carried any weight with the Arab countries and the Palestinians determined to attack us." Em resumo, os EUA e Israel não aceitavam o tom e o linguajar das resoluções por julgarem serem atentatórias contra este último. Segundo o Secretário de Estado Norte-Americano à época, Collin Powel, sobre a retirada estadunidense da Conferência:

"I have taken this decision with regret because of the importance of the international fight against racism and the contribution that this conference could have made to it," he said. "But following discussions today by our team in Durban and others who are working for a successful conference, and others, I am convinced that it will not be possible." 181

Esse acontecimento é importante para que se tenha uma pequena idéia da dimensão do problema étnico racial no mundo que a DEFDH estaria a cargo de consertar.

Inspirados pela Conferencia, durante a $7^{\circ}$ Sessão do Conselho de Direitos Humanos, realizada em março de 2008, Costa Rica, Itália, Suíça e Marrocos decidiram criar um grupo de trabalho intergovernamental e trans-regional chamado de Plataforma Informal de Educação em Direitos Humanos para manter a EDH na agenda do Conselho. Em seguida, com a adesão de Filipinas, Senegal e Eslovênia ${ }^{182}$, a Plataforma de Educação de Formação em Direitos Humanos perdeu a "informalidade" anterior e passa a ser a maior patrocinada da elaboração da DEFDH sob os auspícios do Conselho de Direitos Humanos.

\subsection{O processo coletivo e interativo da elaboração do anteprojeto}

O Comitê Consultivo inicia os trabalhos em agosto de 2008, durante sua IV sessão.

\footnotetext{
${ }^{180}$ Carta das Nações Unidas, art. 13.

${ }^{181}$ KEINON, Herb. “US, Israel quit Durban.” The Jerusalem Post, Jerusalem, 03 Sept 2001. Disponivel em http://www.ngo-monitor.org/article.php?operation=print\&id=1026. Acesso em 07.01.2012.

${ }^{182}$ No entanto, por se tratar de grupo aberto, todo Estado-membro da ONU e Estados com status de observadores e as ONG com status consultivo junto ao ECOSOC podem atender às reuniões públicas deste grupo.
} 
Para atender à requisição do Conselho para elaboração de um projeto de DEFDH, o Comitê esta incumbido de ouvir às partes interessadas, objetivando elencar os elementos adjacentes à EDH que deverão estar contidos no anteprojeto de DEFDH.

Este processo atende ao princípio da participação adotado pela ONU desde a sua reforma em 2006 e reiterado na Resolução 6/10 do Conselho de Direitos Humanos, com o objetivo de favorecer "la toma de conciencia y el compromiso colectivo de todos los interesados, mostrando una visión de conjunto, coherente y concreta, de los principios rectores que deben servir de guía para que se hagan efectivas la educación y la formación en materia de derechos humanos para todos, sin distinción alguna (...)"

O processo de elaboração do anteprojeto da DEFDH contará, portanto, com a participação dos Estados-membros, das organizações internacionais e regionais, do ACNUDH, das INDHs, como também das organizações da sociedade civil, incluindo as ONGs. Essa participação será sobre os possíveis elementos do conteúdo do anteprojeto de Declaração, levando-se em consideração instrumentos relevantes já existentes.

\subsubsection{A coleta de informações}

A primeira tarefa era decidir a forma através da qual os atores pertinentes iriam contribuir. O Comitê Consultivo optou por disponibilizar formulários de consulta (questionários) dirigidos (i) aos governos, (ii) às organizações internacionais, (iii) às INDHs e (iv) à sociedade civil (inclui-se aqui além das ONGs, a academia e os indivíduos).

Para orientar este processo, e simultaneamente ao tempo da elaboração das perguntas, Decaux - redator encarregado da redação - elaborou e publicou um documento que contém os elementos do marco conceitual para as respostas dos questionários e consultas futuras. Deve-se chamar a atenção para o fato deste documento mostrar-se uma referência para a participação no processo de consulta. Ele é um guia de orientação para as respostas aos questionários, que, se por um lado, otimiza (ou mesmo viabiliza) o processo de consulta, por outro, não dá a oportunidade de ouvir dos consultados livremente. Com isso queremos dizer que as respostas não são espontâneas, mas orientadas pelos elementos da referida norma de procedimentos, fato observado amplamente durante a análise dos questionários.

Este documento, chamado na versão espanhola "Elementos del marco conceptual para la labor y las consultas futuras en aplicación de la resolución 6/10 del Consejo de 
Derechos Humanos", está dividido em três partes: (i) consultas; (ii) marco conceitual e (iii) documentação. A primeira parte determina a quem estes questionários são dirigidos especificamente ${ }^{183}$ e os temas a serem tratados, a saber: (i) boas práticas, dificuldades e lacuna; (ii) mecanismos de comunicação inovadores, criativos e práticos e (iii) eficácia da Década e do Programa Mundial de Educação em Direitos Humanos.

A segunda parte traz os marcos conceituais ligados à EDH, dividido em (i) orientações gerais; (ii) parâmetros; (iii) documentação, abrangendo inúmeros elementos, classificados e subdivididos da seguinte maneira: (a) obrigações do Estado; (b) a visão sobre a EDH; (c) atenção a contextos e condições prévias; (d) os componentes da EDH; (e) as etapas da EDH; (f) conteúdos para EDH e (g) as ferramentas para a EDH.

Ao final, o documento indica todos os instrumentos internacionais que servem de fonte para este estudo.

Vale observar o quanto a teoria sobre a EDH foi desenvolvida abrangendo diversos elementos subjacentes a ela. Estes elementos que constam no anteprojeto de Declaração são resultado do documento retro resumido que, por sua vez, resume uma coleção de contribuições sobre a concepção de EDH desde a DUDH até compartilhamento de boas praticas. Seguindo esta linha cronológica, ultrapassado o processo de participação dos atores pertinentes, o entendimento global sobre a EDH estará consolidado.

\subsubsection{As respostas aos questionários}

Tratou-se na verdade de dois questionários: um dirigido aos governos e $\mathrm{INDHs}^{184} \mathrm{e}$ outro dirigido às organizações internacionais e à sociedade civil. Esta separação cumpre razões lógicas segundo a natureza e o escopo destes atores e sua relação com a educação e a EDH. Veremos que a EDH é responsabilidade da comunidade internacional, da sociedade, da comunidade local, da família, porém, sobretudo, do Estado, através de sua função orgânica de criar e executar políticas públicas e devido a seus compromissos

\footnotetext{
${ }^{183}$ A saber: (i) a UNESCO; (ii) os Estados-membros da ONU; (iii) as partes interessadas (Organizações Internacionais, organizações regionais, ONGs, organizações da sociedade civil, etc.), especialmente as INDH; (iv) Cátedras da UNESCO, universidades, "ciências pedagógicas", Sindicatos de professores/educadores; (v) Uniões interparlamentares e redes de juristas.

${ }^{184}$ Os institutos nacionais de direitos humanos ganham diferentes nomes (Commission, Ombudsman, Procuradoria, secretaria) e competência de país para país, podendo mesmo não existir, tendo suas atribuições a cargo de diferentes órgãos. Fundamental ressaltar a importância da existência deste órgão para a promoção e proteção dos direitos humanos. Seguindo os princípios de Paris que norteiam o bom funcionamento de um Instituto Nacional de Direitos Humanos, independente, com jurisdição qasi. Os institutos cumpririam papel de satélite nos Estados-partes do funcionamento do Conselho de Direitos Humanos e seu maior parceiro na busca por melhora na promoção e proteção dos direitos humanos em nível doméstico.
} 
internacionais e obrigações decorrentes.

Até 28 de janeiro de 2009 - data na qual o Comitê decidiu estender o prazo para recebimento dos questionários até 15 de março de 2009 - 109 relatórios foram recebidos. Motivados pela nova convocação e abertura de prazo, mais 40 relatórios foram enviados pelos participantes ao Comitê ${ }^{185}$. Como resultado total da coleta de informações, o Comitê Consultivo recebeu 149 respostas: 57 de governos e entidades federais; 30 das INDHs; 14 de organizações internacionais e 48 da sociedade civil (43 de ONGs e 5 da academia e indivíduos). ${ }^{186}$

Das respostas recebidas pelos governos ou INDHs, o projeto recebeu contribuições de 75 estados $^{187}$ diferentes com a seguinte distribuição geográfica: 4 países da Oceania, 15 países da África, 15 da Ásia, 15 das Américas ${ }^{188}$ e 38 da Europa. ${ }^{189}$ Salta aos olhos a participação europeia no processo de colaboração com $51 \%$ das respostas. Entendemos esse desequilíbrio no balanço geográfico como consequência da maior tradição da cultura de direitos humanos encontrada na Europa. O tema direitos humanos é muito bem recebido neste continente, talvez por ter ele conhecido os horrores de séculos de guerras e por associação da idéia dos direitos humanos em contraposição ao nazismo que é algo pouco tangível para outras nações, como as latino-americanas, por exemplo. Assim, se alguém se coloca contra os direitos humanos, é nazista. Isto não quer dizer que uma maior cultura de direitos humanos reflita necessariamente em políticas e práticas adequadas ou ainda na ausência de cultura concorrente contraria aos direitos humanos, mas que o tema dos direitos humanos estará mais comumente na agenda política através de uma cultura favorável eles.

Essa cultura também é fomentada através da grande concentração de departamentos acadêmicos, centros de estudos, ONGs, etc., que tratam do tema dos direitos humanos neste continente. Esse fenômeno, no entanto, enseja acusações de eurocentrismo em relação aos direitos humanos, tema que abordaremos mais adiante quando tratarmos do

\footnotetext{
${ }^{185}$ Alguns recebidos bem além do prazo limite, demonstrando o Comitê, desapego por um formalismo rígido, uma vez que o intuito é possibilitar a ampla participação nesta fase do processo de elaboração do anteprojeto de Declaração.

186 Cf lista completa em Table of replies to the questionaries. Disponível em www http://www2.ohchr.org/english/bodies/hrcouncil/education/1stsession.htm

${ }^{187}$ Alguns países enviaram mais de um relatório através de diferentes órgãos.

${ }^{188}$ Os países americanos que submeteram respostas ao questionário do Comitê Consultivo foram Argentina, Canadá, Colômbia, Costa Rica, Equador, Honduras, México, Trinidade e Tobago e Venezuela.

${ }^{189}$ Considerou-se a Armênia como país europeu uma vez que, apesar de estar localizado no que se chama Eurásia, a Armênia é Estado membro do Conselho da Europa.
} 
multiculturalismo e a $\mathrm{EDH}^{190}$.

Não crermos ser possível tirar conclusões muito profundas sobre o perfil dos países que responderam à consulta. A resposta ao questionário não é uma responsabilidade obrigatória do Estado, e, portanto, resta a cargo das missões diplomáticas permanentes em Genebra, eventualmente não muito preparadas, e, comumente, muito atarefadas.

Contribuíram com respostas países dos mais variados, desde os ricos e desenvolvidos Canadá, Mônaco, Luxemburgo, Holanda, França, Reino Unido, Vaticano, por exemplo, aos ditos em desenvolvimento Argentina, Colômbia, Índia, Angola, Marrocos, Turquia, Venezuela, entre outros, passando pelos pequenos Mauricio, Samoa, Burkina Faso, etc. Ausências marcantes também foram observadas, em especial a brasileira e a estadunidense.

Dentre os relatórios submetidos pelas organizações internacionais, responderam ao questionário de consulta: (i) Conselho da Europa; (ii) Comissão Europeia; (iii) FAO; (iv) $\mathrm{OSCE}^{191}$; (v) Secretariat of UN Permanent Forum on Indigenous Issues; (vi) UNESCO; (vii) UNFPA ${ }^{192}$; (viii) $\mathrm{UNHCR}^{193}$; (ix) UNICEF; (x) United Nations Interregional Crime and Justice Research Institute (UNICRI); (xi) United Nations Department of Public Information (DPI); (xii) UNRWA ${ }^{194}$; (xiii) World Food Programme (WFP) e (xiv) $\mathrm{OMS}^{195}$.

Uma gama variada de ONGs com escopos distintos respondeu ao questionário, bem como Organizações de classe, sindicatos, entidades de escopo religioso, institutos independentes de direitos humanos, etc.

Como dissemos, o Comitê Consultivo preparou dois questionários diferentes de acordo com a modalidade do colaborador.

O questionário submetido aos governos e INDHs trazia cinco perguntas:

1. É o direito à EDH considerado como tal no seu sistema nacional?

2. Se sim, qual a base legal? Direito internacional, Constituição, Legislação nacional, prática administrativa? Outro?

3. a) Qual modalidade prática foi colocada em marcha para a implementação do direito humanos à educação e formação em direitos humanos? (Se a resposta para a pergunta 1 for afirmativa);

b) Na ausência de um reconhecimento específico do direito humano à educação e formação em direitos humanos, o que é feito na área da

\footnotetext{
${ }^{190}$ Trataremos sobre o tema do eurocentrismo no subcapitulo 4.2 "Sobre o multiculturalismo", p. 138.

${ }^{191}$ OSCE - Organization for Security and Cooperation in Europe.

${ }^{192}$ UNFPA - Fundo de População das Nações Unidas.

${ }^{193}$ UNHCHR (ACNUR) - Agencia da ONU para os Refugiados.

${ }^{194}$ UNRWA - United Nations Relief and Works Agency for Palestine Refugees.

195 OMS - Organização Mundial da Saúde.
} 
educação e formação em direitos humanos? (Se a resposta para a pergunta 1 for negativa).

4. Na educação e formação em direitos humanos, quais são: as prioridades? Os desafios? As boas práticas? Prospectos para o futuro?

5. Comentários e sugestões sobre novos elementos para uma futura declaração sobre a educação e formação em direitos humanos.

Por sua vez, o questionário submetido às organizações internacionais e à sociedade civil, trazia quatro perguntas:

1. É o direito à EDH reconhecido e levado em consideração ao planejar suas atividades?

2. Qual é o papel da sua instituição para a implementação do direito à EDH? Você considera este papel adequado?

3. a) Quais modalidades práticas são colocadas em ação para a implementação do direito à EDH?

b) $\mathrm{Na}$ ausência de um reconhecimento explícito do direito à $\mathrm{EDH}$, o que é feito na área de EDH?

4. Comentários e sugestões sobre novos elementos para uma futura declaração sobre a educação e formação em direitos humanos.

Como se pode notar, a diferença entre eles está na pergunta 1, se o direito a EDH é reconhecido como tal no seu sistema nacional, para o primeiro grupo (governos e IDH), e no planejamento de suas atividades, para o segundo (Organizações internacionais e sociedade civil).

As perguntas 2 e 3 buscam saber do primeiro grupo, qual a fundamentação legal e as modalidades práticas de implementação da EDH, enquanto do segundo, qual o papel na EDH e as modalidades práticas.

Outra diferença está na pergunta 4 dirigida ao primeiro grupo, onde se indaga qual são as prioridades, os desafios, as boas práticas e os prospectos para o futuro da implementação da EDH. Para o segundo grupo, esta pergunta não foi dirigida, concluindo o questionário igualmente para todos os colaboradores, convidando comentários e sugestões sobre novos elementos a constar do anteprojeto.

Foi possível notar um amplo rol das mais variadas respostas enviadas através de toda a sorte de documentos, desde primários suficientes para envergonhar qualquer missão diplomática e informes demonstrando claramente a não compreensão das perguntas, documentos intermináveis, uma dissertação de mestrado, um desabafo, até excelentes documentos elaborados ${ }^{196}$, vindos de todas as categorias de colaboradores.

Dos relatórios recebidos dos Estados diretamente, ou seja, não através das INDHs, o

${ }^{196}$ É o caso das respostas de Canadá, Países Baixos, Chipre, Honduras, etc. 
que se pôde notar foi que a primeira e a segunda pergunta eram respondidas quase como uma prestação de contas, não atendendo ao objetivo do questionário, o que denota a importância das INDHs, especialmente se seu mandato atender aos Princípios de Paris ${ }^{197}$.

As respostas às pergunta 1,2 e 3 são exemplo ou da incompreensão do questionário ou da sua utilização como maneira de fazer boa propaganda de seus governos. Vale concordar que a pergunta poderia ter sido elaborada de maneira mais clara porque "sistema nacional" pode ser o sistema legal, educacional, administrativo, etc. No entanto, o que se notou foi que quase a totalidade dos relatórios afirmavam que sim, o direito à EDH é considerado um direito, sem, contudo, demonstrar a fundamentação jurídica nacional onde se expressa esse direito claramente, já passando para ideais genéricos de seus planos de educação ("formar cidadão", "desenvolver capacidades", "tolerância”, etc.) em que a EDH estaria presente mesmo que indiretamente. Por exemplo, o relatório enviado pelo governo monaguesgo que afirma genericamente ${ }^{198}$ sem informar se é o direito à EDH positivado no seu ordenamento, passando simplesmente a discorrer sobre as práticas educacionais, que, segundo eles, é permeada pelos temas de direitos humanos, contando com a parceria da UNESCO. Neste sentido, outro bom exemplo vem do governo do Chipre:

\footnotetext{
"the overall aim of education in Cyprus is the development of free and democratic citizens (...) who contribute (...) to the promotion of cooperation, mutual understanding, respect and love among individuals and people for the prevalence of freedom, justice and peace."
}

Alguns países, entretanto, responderam corretamente à esta pergunta informando que apesar de não haver um direito à EDH positivado, são empregados esforços dedicados a EDH. É o caso do relatório dos Países Baixos: "Yes, although not specifically on the right to human rights educations but on human rights in general within the context of education in citizenship and social integration."

Nesta esteira, o Estado canadense, por exemplo, responde negativamente à positivação do direito à EDH, no entanto, traz exemplos concretos de políticas públicas direcionadas à promoção dos direitos humanos que incluem a EDH em 9 das suas 10 regiões. O Japão, por seu turno, informa que a EDH não está posicionada como um direito legal, mas há outros instrumentos nacionais que promovem a EDH no sistema educacional japonês.

\footnotetext{
${ }^{197}$ Sobre os Princípios de Paris Cf http://www.ohchr.org/Documents/Publications/FactSheet19sp.pdf 198 "Le droit à l'education et à la formation aux Droits de l'Homme est reconnu tel quel dans le système national monégasgue".
} 
Por entendermos pouco valiosas as informações transmitidas através de formulários de respostas "prestação de contas", e, por não ser o estudo profundo da EDH nos sistemas de educação nacionais o foco desta obra, concentramo-nos mais na pergunta 4, (quais são: as prioridades? Os desafios? As boas práticas? Os prospectos para o futuro?) e em especial a pergunta 5 (comentários e sugestões sobre novos elementos).

Todos os relatórios enviados recebem bem a iniciativa de se elaborar um documento internacional sobre a $\mathrm{EDH}^{199}$, bem como o processo de participação que lhes é proporcionado. Muitos apontam para função primeira da Declaração que, em seu juízo, é atenção pública ${ }^{200}$ para a temática da $\mathrm{EDH}^{201}$.

O relatório do governo holandês, por exemplo, sugere que seja feita referência expressa à indivisibilidade de ambos os direitos humanos civis e políticos e os econômicos, sociais, dando força ao processo ainda incipiente de aplicação progressiva dos direitos econômicos, sociais e culturais, ditos de segunda geração.

Discussão interessante se deu a respeito da não existência de um direito humano à EDH, entendido por muitos que a partir desta Declaração, este direito, ao ser positivado passaria a existir, com o que discordam a maioria das contribuições, em especial a INDH neozelandesa:

\footnotetext{
"Some have said that the right to HRE does not yet exist. This should not be conceded: it is a strongly implied right (e.g. UDHR preamble and art. 26 (2), ICESCR art. 13 (1) \& (42). The Declaration should affirm the right and then spell out what it means in practice drawing particularly on elements of the World Programme. ${ }^{202}$
}

Os relatórios enviados somaram grande material sobre a EDH e são de fundamental importância para a construção do entendimento internacional sobre ela. As contribuições serão utilizadas como fonte no deslinde desta parte da dissertação, quando analisaremos o projeto de DEFDH e seu conteúdo.

Sem embargo, há um relatório que não podemos deixar de analisar. Dentre os 159 relatórios recebidos, somente um destoava completamente dos outros. Primeiro, chamava a atenção por ser de um dos dois únicos indivíduos que responderam ao questionário. $\mathrm{O}$ outro motivo, e este em especial, são as criticas e alegações contidas nele, as quais não podemos ignorar.

O californiano David Lempert, é professor, advogado, antropólogo, educador, autor,

\footnotetext{
199 Todos exceto o relatório de David Lempert que será analisado ao final deste subcapítulo.

${ }^{200}$ Tradução do autor para public awareness.

${ }^{201}$ Por exemplo, os governos da Armênia e Angola.

202 Do relatório da Human Rights Commission of New Zealand.
} 
e consultor. ${ }^{203}$ Fundador da Unseen America Projects Inc e presidente do conselho da Diaspora Bridge Center Project é consultor sobre direitos humanos e educação para a ONU.

Lempert manifesta em seu relatório sua veemente discordância profissional com a preparação da DEFDH por entender que ela trará descrédito à promoção dos direitos humanos e que poderá violar outros tratados e direitos (incluindo os direitos culturais da criança). Em seu ponto de vista, a DEFDH trivializa o Direito Internacional e os tratados ao transformar promoção de direitos em uma nova forma de lobbying por interesses especiais e por ferramentas e meios mas que os fins. Alega que existe um "negocio dos tratados" que aprovam, promulgam e educam o público sobre tratados que são crescentemente contraditórios, vagos, e inaplicáveis.

Afirma que por diversas semanas os especialistas estiveram reunidos sem chegar em uma definição pacífica do que seja a EDH. Não há ainda estândar para medir o impacto e a qualidade da EDH e não existe um professional journal ou organização para rever o próprio trabalho do educador em EDH. Segundo ele, por não haver uma definição sobre o que é a EDH, mais além, por não haver consenso sobre os métodos avaliativos dos impactos alcançados, a iniciativa de preparar um tratado para forçar outros a financiarem que não se consegue concordar profissionalmente é irresponsável.

Dos dois exemplos que ele apresenta do que entende ser o mal uso do conceito de EDH e que seria agravado com a DEFDH, escolhemos um para ilustrar suas ideias do porquê o sistema jurídico internacional falha em assegurar direitos.

\begin{abstract}
"Há apenas poucos dias atrás, eu tive uma discussão com a UNDP-Armênia sobre um projeto que eles já estavam comprometidos de "Educação para a tolerância" mas sem alguma analise que supostamente deve ser feita em intervenções internacionais. Uma grande ONG que promove os direitos das crianças disse ao UNDP e a UNICEF que eles precisavam promover a educação para a tolerância e o projeto foi financiado para inserir a educação para tolerância, substituindo algo que as crianças já tinham em sua grade curricular. Armênia, como sabemos, é agora $98 \%$ Armênia e cristã e tolerância era algo que costumava ser ensinado nas igrejas (que agora estão enfraquecidas mas que eram a instituição cultural chave para os Armênios), em casa e na comunidade. Eu perguntei à UNDP exatamente qual era o problema de intolerância que a educação era suposta a resolver. Quem era intolerante? Eram as crianças e a falta de educação que causaram o indefinido problema da intolerância? O que a educação faria para mudar os comportamentos que estavam causando o dano?"
\end{abstract}

Lempert advoga que o problema decorre do fato de transformar-se meios como a

${ }^{203} \mathrm{Cf}$ http://www.policyinnovations.org/innovators/people/data/david_lempert. 
educação em direitos ${ }^{204}$. Segundo ele, a DEFDH atende a interesses dos prestadores de serviços da EDH de maneira que ela trivializes international law and everything we say we believe in, in order to promote the interests of services providers, without actually protecting the right holders.

Em um relatório confuso, e certamente radical, alega adiante que o sistema da ONU já está promovendo o direito à educação nas Metas de Desenvolvimento do Milênio, que segundo ele, está violando outros direitos ao colocar as crianças em escolas públicas o que homogenizes the population, destroys ethnic differences, builds allegiance to the state (and to militarism, urbanization, production and consumerism) and prepares children to work in industry rather than traditional occupations. Dessa maneira, na opinião de Lempert, a ONU não está atenta às tradições culturais.

Seu temor é pelo efeito da globalização que poderá permear esse processo de EDH internacional, desse modo

\section{children will also lose their right NOT to be indoctrinated in a new up scheme that politically determines what they are supposed to know about "universal" human rights but is determined by those whose views are "more universal than others" (perhaps more "global" and "globalizing").}

Suas conclusões são que o caminho a ser tomado deveria ser o de encontrar meios reais de coibir as organizações internacionais e os governos a cumprir os direitos previstos nos tratados já assinados, apesar de eles, em sua opinião, normalmente refletirem o problema mais que a solução.

Apesar de todo pessimismo, não podíamos deixar de colar as reflexões do único relatório que não concorda com o movimento de positivação da EDH em instrumento especifico. Seguindo o tom do inicio do relatório, ele pergunta: Is this Declaration really about protecting rights and improving education and protecting those who are being educated (kids) and really empowering the victims, or is it about protecting and advancing our own careers?

Sobre a preocupação na avaliação e monitoramento, a Declaração deveria estabelecer algum tipo de mecanismo de prestação de contas, lembrou o governo macedônio.

Deveria conter força vinculante, dando à Declaração mais poder, recomendou a ONG Ludwig Boltzmann. Concordando com esta observação e reafirmando o risco da Declaração tornar-se não efetiva, dissertou o governo espanhol:

The acceptance of National and International Declarations and compromises,

204 "This is the danger of turning MEANS like education into a "right"." 
even the same laws, do not endure nor guarantee by itself the promotion of Human Rights, looking at the future, it should be demanded measurements, plans and specific actions that may stimulate them beside appraisals and follow ups of the putting into practice political actions on education.

A INDH de Fiji, por exemplo, além de se declarar a única INDH da região do pacífico, informa em seu relatório que Fiji não ratificou ainda o PIDESC, mas que a seção 39 da Constituição de 1997 protege a educação básica para toda pessoa em Fiji. Vale lembrar, que a não ratificação de um instrumento internacional exime o Estado de responsabilidade internacional. O fato de Fiji ter uma lei nacional que supra a lacuna da não ratificação do PIDESC, não gera obrigação internacional.

Ainda que a Declaração contenha mecanismos de cobrança e prestação de contas, haverá o risco de seu conteúdo não se traduzir em ação concreta em nível nacional, o que, para a INDH irlandesa, seria o maior desafio deste processo.

The current challenge for HRE remains one of translating UN recommendations into concrete action at the national level. Reference should be made to the need for consistent, systematised and sustained national policies for HRE, and for mechanisms to ensure State provision of HRE is compliant with their international legal obligations.

Diante os importantes debates suscitados, um encontro presencial fez-se necessário para avançar na busca por consenso sobre os elementos a constarem deste novo instrumento internacional.

\subsubsection{O seminário de Marrakesh.}

A fase final da coleta de contribuições dos Estados e INDHs e das Organizações Internacionais e sociedade civil, culminou no Seminário sobre a Declaração da ONU sobre Educação e Formação em Direitos Humanos, proposto pela Plataforma para a EDH e realizado em Marrakesh, Marrocos, em julho de 2009, contando com a participação de 94 pessoas, representando 32 estados $^{205}$ e 24 organizações internacionais e ONGs ${ }^{206}$.

O Seminário foi uma grande oportunidade para discutir os preparativos da Declaração diante os aportes trazidos pelas respostas aos questionários disponibilizados, tendo como temas centrais: (i) os objetivos e desafios da Declaração (análise dos questionários) para implementação de mecanismos em nível internacional, regional e nacional; (ii) os princípios e visão geral da Declaração buscando a indivisibilidade dos direitos humanos por meio de uma abordagem integrada da EDH e suas dimensões

\footnotetext{
${ }^{205}$ Marrocos enviou uma comitiva de 32 representantes dos Ministérios da Justiça, das Relações Internacionais, da Educação e do Interior e do Conselho Consultivo sobre Direitos Humanos.

${ }^{206} \mathrm{Cf}$ http://www2.ohchr.org/english/bodies/hrcouncil/advisorycommittee/HR_education_training.htm
} 
culturais e socioeconômicas; (iii) as obrigações dos Estados na Declaração de acordo com o principio da não-discriminação e da atenção aos grupos vulneráveis e coordenação, avaliação e seguimento das iniciativas pertinentes; (iv) o papel de outros atores responsáveis na Declaração, a saber as INDHs, as ONGs, a mídia e as responsabilidades dos setores públicos e privados; (v) o papel dos mecanismos de proteção e promoção da EDH na sistema ONU através dos órgãos de tratado, procedimentos especiais e exame periódico universal.

O Seminário foi encerrado com uma mesa redonda sobre diversidade e complementaridades setoriais, debatendo-se acerca da (i) educação primária e secundária, (ii) da educação superior e pesquisa científica, (iii) da educação profissional (advogados, policiais e forças armadas), (iv) da formação permanente e educação extracurricular e (v) das ferramentas de publicização ${ }^{207}$.

Esta primeira fase da etapa participativa visava reunir elementos para a feitura do anteprojeto da Declaração, apresentada pelo Comitê Consultivo em dezembro de 2009, para que se inicie a segunda fase de participação, abrindo prazo para comentários, no entanto, agora, com base no anteprojeto.

\subsection{O anteprojeto da Declaração e os comentários.}

Ultrapassada a primeira fase da participação da comunidade internacional, o Comitê conclui a redação do anteprojeto da DEFDH "Movido por el deseo de dar a la comunidad internacional una señal clara de la importancia fundamental de la educación y la formación en materia de derechos humanos para la promoción y la protección de estos derechos ${ }^{, 208}$.

Saudando a participação recebida até o momento e agradecendo aos Estados e outros atores envolvidos, o Comitê aproveita para enaltecer a participação das INDHs, tomando nota das profundas discussões sobre o projeto nos debates interativos no seu IV período de sessões, recomenda a ampla difusão para que as partes interessadas possam contribuir mais uma vez para a conformação final do projeto.

Decidimos elencar os pontos e objetos cobertos pelo anteprojeto uma vez que ele contem todos os elementos considerados base para a formação da projeto final da DEFDH.

\footnotetext{
${ }^{207}$ Tradução do autor para awareness raising tools.

${ }^{208}$ Preâmbulo do anteprojeto de Declaração das Nações Unidas sobre a Educação e Formação em Direitos Humanos.
} 
Posteriormente, analisaremos a DEFDH, comentando sobre seus artigos.

O anteprojeto de Declaração apresentou 37 parágrafos, divididos em três partes, resumidos da seguinte maneira: (i) direitos e obrigações ( $\S \S 1$ ao 13); (ii) medidas de implementação e seguimento ( $§ 14$ a 36) e disposições complementares ( $(37)$.

Inicialmente, o preâmbulo faz referência ao artigo 13 da Carta das Nações Unidas que encarrega a Assembleia Geral de fomentar a cooperação internacional. Relembra a DUDH como ideal comum de todos os povos e nações. Reafirma que os Estados estão obrigados a velar para que a educação tenha como objetivo fortalecer o respeito aos direitos humanos, como dispõe também o PIDESC e demais instrumentos internacionais de direitos humanos.

Cita a Declaração e o Programa de Ação de Viena e o objetivo de fazer efetivo o direito à educação como meio de respeitar os direitos humanos.

Faz menção à reunião de cúpula mundial de direitos humanos de 2005 em que os chefes de estado e de governo apoiaram "que se promueva la educación y la divulgación sobre derechos humanos a todos los niveles, incluso mediante la ejecución del Programa Mundial para la educación en derechos humanos (...) e insta[n] a todos los Estados a preparar iniciativas en ese sentido".

Cita os progressos logrados na Década das Nações Unidas para a EDH (1995-2004) e o Programa Mundial para a EDH e seu respectivo Plano de Ação.

Alentando para as Metas de Desenvolvimento do Milênio (2015), menciona em especial o acesso igualitário de crianças, sem distinção de gênero, a todos os níveis da educação.

Reconhece as diversas iniciativas adotadas pela ONU, UNESCO e outras organizações internacionais, regionais, bem como iniciativas nacionais por parte das autoridades publicas e da sociedade civil, apresenta-se resumida da seguinte maneira:

Parte 1 - Direitos e obrigações:

$\S 1$ - a educação e formação em direitos humanos é um direito fundamental. Em seguida reafirma os princípios da universalidade, indivisibilidade e interdependência deles;

$\S 2$ - o direito à EDH é componente do direito a educação para todos e intrinsecamente ligado a total realização do direito à educação;

$\S 3$ - o direito a EDH é o direito à educação de qualidade baseada nos princípios da DUDH sendo os direitos humanos vetor e alvo da educação;

$\S 4$ - o direito à EDH objetiva desenvolver uma cultura universal dos direitos humanos, permitindo a todos 
saber seus direitos e obrigações em relação aos direitos dos outros;

$\S 5$ - o direito à EDH está baseado no principio da igualdade, em particular de gênero, e busca assegurar oportunidade igual através do acesso a educação sem discriminação;

$\S 6$ - o direito à EDH deve estar presente em todos os níveis e formas de educação e formação seja formal ou não;

$\S 7$ - A EDH é um processo permanente que começa na idade escolar e se estende por toda a vida;

$\S 8$ - o direito à EDH deve ser adaptável à diferentes situações assim como respeitar a diversidade cultural e tornar-se uma alavanca para o desenvolvimento. Deve-se ser alcançada através de linguagem adequada ao publico alvo respeitando-se e utilizando-se da diversidade cultural;

$\S 9$ - o direito à EDH deve integrar a perspectiva da era digital;

$\S 10$ - o direito à EDH corresponde a uma visão transversal, inclusiva e holística e da necessidade de formar os formadores para se obter uma educação de qualidade;

$\S 11$ - o direito à EDH envolve conexão intima entre escola, família, comunidade local e sociedade para erradicar a violência escolar, doméstica, principalmente cometida contra o sexo feminino, bem como todas as formas de violência social;

$\S 12$ - a EDH deve dar atenção aos grupos vulneráveis que devem ter assegurado o acesso efetivo à educação fundamental como ainda à EDH para que se possa exercer seus direitos, particularmente em situação de fome, deficiência, analfabetismo, exclusão ou marginalização, em especial em relação aos nômades, migrantes, deslocados e refugiados.

$\S 13$-a EDH deve também atentar aos povos indígenas e os indivíduos pertencentes à minorias nacionais;

Parte 2 - Medidas de implementação e seguimento:

$\S 14$ - sobre o direito à EDH e a responsabilidade primária do Estado de respeitar, proteger e implementá-los através de políticas proativas;

$\S 15$ - sobre a responsabilidade específica do Estado de implementar efetivamente o direito à EDH dos grupos vulneráveis com base no critério de acessibilidade, aceitabilidade, adequação de materiais e adaptabilidade da educação e formação;

$\S 16$ - sobre a responsabilidade específica do Estado de educar e formar seus servidores em particular os funcionários do poder judiciário e as forças armadas integrando o direito humanitário internacional e o direito penal internacional;

$\S 17$ - sobre a necessidade de uma mobilização de todos os setores da sociedade (empresas, organizações não governamentais, sindicatos, instituições religiosas, associações de classe, docentes, os pais dos alunos, empresas, meios de comunicação, etc.);

$\S 18$ - sobre EDH e a necessidade do apoio de vontade política forte, demonstrada através de uma estratégia holística de implementação nacional e da mobilização de pessoal e recursos financeiros para tal;

$\S 19$ - sobre a importância que podem ter os INDHs na implementação do direito à EDH;

$\S 20$ - sobre a necessidade de estratégia - progressiva e continua - com objetivos a longo prazo, com a participação de todos, levando-se em consideração a diversidade de situações culturais, sociais e econômicas para a implementação do direito à EDH; 
$\S 21$ - sobre a responsabilidade da ONU em treinar seus funcionários (civis e militares) e, em situações de crise, promover a EDH nos programas de consolidação da paz e (re)construção do Estado;

$\S 22$ - sobre a responsabilidade das organizações internacionais e regionais em promover a EDH entre seus funcionários e integrá-la em suas atividades e programas de cooperação;

$\S 23$ - sobre a importância da cooperação internacional multi ou bilateral em apoiar e fortalecer os esforças nacionais através de medidas de incentivo e projetos piloto;

$\S 24$ - sobre a necessidade da complementaridade dos esforços das organizações internacionais, regionais, nacionais e locais;

$\S 25$ - sobre a criação de um fundo internacional de contribuições voluntárias para a EDH para o financiamento de iniciativas e projetos de campo;

$\S 26$ - sobre a criação de um observatório internacional para a educação e formação em direitos humanos com o objetivo de facilitar e coordenar a aplicação da Declaração;

$\S 27$ - sobre a avaliação constante dos esforços empregados para a efetividade do direito à EDH;

$\S 28$ - sobre o monitoramento nacional da satisfação do direito à $\mathrm{EDH}$, através de uma estratégia adequada às necessidades e prioridades nacionais, que conte com a coordenação interministerial, incrementando o papel das INDHs e a coalizão com outros atores;

$\S 29$ - sobre o seguimento para a realização do direito à EDH que requer a ratificação universal dos instrumentos internacionais e dos distintos mecanismos e órgãos competentes;

$\S 30$ - sobre a aprovação de Observações Gerais sobre a EDH pelos órgãos de tratado e ênfase sistemática nas perguntas endereçadas aos Estados e em suas Observações Finais;

$\S 31$ - sobre a EDH ser também objeto do Exame Periódico Universal;

$\S 32$ - sobre a garantia de liberdade acadêmica e a proteção dos direitos humanos dos educadores e educadoras formais ou informais;

$\S 33$ - sobre a pesquisa teórica e prática, especialmente das ciências da educação e pedagógicas, mas também do Direito Internacional dos Direitos Humanos e ainda as ciências da informação, através de redes de cooperação de institutos especializados como base para a realização do direito à EDH, definindo conceito e metodologia comuns de ensino através do diálogo intercultural;

$\S 34$ - sobre a necessidade da EDH ser enfatizada através das novas tecnologias da informação, através de campanhas de conscientização para combater os estereótipos e os discursos de ódio;

$\S 35$ - sobre a EDH basear-se na riqueza cultural e nas tradições dos diferentes países e utilizar-se de manifestações artísticas como vetores da formação e sensibilização sobre os direitos humanos;

$\S 36$ - sobre nomeação de embaixadores da boa vontade em âmbito internacional e nacional;

\section{Disposições finais:}

$\S 37$ - Sobre a presente declaração ter como objetivo definir programas para mobilizar esforços dos Estados e outros atores responsáveis para implementar através de atividades específicas, envolvendo setores 
particulares, ou grupos alvo, ou grupos vulneráveis.... ${ }^{209}$

Do anteprojeto da Declaração pode-se extrair alguns temas centrais interrelacionados com a educação e formação em direitos humanos que concentraram a atenção do Comitê, através de sua pesquisa própria e da compilação e análise das informações contidas nos questionários de consulta e discutidas no seminário de Marrakesh.

Dessa forma, o anteprojeto trata dos temas listados abaixo: (i) definição do conceito de EDH; (ii) responsabilidade geral e específica sobre o direito à EDH; (iii) cultura universal dos direitos humanos; (iv) principio da igualdade; (v) níveis e modalidades de educação; (vi) multiculturalismo; (vii) grupos vulneráveis; (viii) novas tecnologias da informação; (ix) estratégias de implementação e (x) INDHs.

É com base neste documento que o Comitê insta, por meio da comunicação 10/28, a participação novamente dos atores envolvidos, para enviarem comentários sobre a redação do anteprojeto, em especial sobre os temas incluídos e como se apresentam, os temas não incluídos, assim como seus comentários gerais e sugestões.

Diferente da primeira fase de participação (quando 149 colaboradores responderam ao questionário), com o anteprojeto pronto, o Comitê recebeu apenas 10 colaborações $^{210}$.

A ONG Soka Gakkai International (SGI) reconheceu que o texto do anteprojeto reflete as discussões ocorridas durante o Seminário organizado pela Plataforma em Marrakesh, demonstrando-se entusiasmada pelo processo participativo, com o que concorda a Human Rights Education Associates (HREA) e a ONU. Esta, em seu relatório enviado através da Unidade de Metodologia, Educação e Formação do Alto Comissariado para os Direitos Humanos (através do $\mathrm{METU}^{211}$ ), manifesta, sobretudo, que o movimento pela educação e formação dos direitos humanos a ser impulsionado pela Declaração deveria concentrar esforços na implementação deste direito em âmbito nacional, contida na

\footnotetext{
${ }^{209} \mathrm{O}$ ultimo parágrafo é encerrado com reticências indicando estar o documento aberto para modificações. $\mathrm{O}$ texto do $\S 37$ no original em francês: "La présente déclaration-cadre, qui vise à définir un tronc commun pour mobiliser les efforts des Etats et de toute les parties prenantes, devrait trouver son prolongement dans des développements spécifiques, portant soit des secteurs particulieurs (medias, TIC), soit des groupes cibles (profession de santé, police et forces armées), soit des groupes vulnérables..."

${ }^{210}$ Enviaram comentários sobre o anteprojeto de declaração: 1) organizações internacionais: a ONU (The Office of the High Commissioner for Human Rights (OHCHR), Methodology, Education and Training Unit (METU)); 2) academia: The Ludwig Boltzmann Institute for Human Rights Vienna e University of Teacher Education Central Switzerland); 3) institutos nacionais de direitos humanos: Conseil Consultatif des Droits de l'Homme du Maroc); 4) ONGs: Anistia Internacional, Equitas - International Centre for Human Rights, Human Rights Education Associates, International Indian Treaty Council, Soka Gakkai International - UN Liaison Office e The International Disability Alliance).

${ }^{211} \mathrm{Na}$ sigla em inglês de Methodology, Education and Training Unit.
} 
parte II do anteprojeto.

Procedimentalmente, a preocupação (e certo descontentamento) deu-se pelo fato de o anteprojeto ter sido formulado no idioma francês e não haver o documento traduzido formalmente para o inglês ${ }^{212}$ já que foi disponibilizado apenas a tradução informal elaborado pela secretaria do Comitê Consultivo e isso prejudicou a análise e elaboração dos comentários, criticas e sugestões. Neste sentido, destaca-se o comentário da Anistia Internacional:

The draft Declaration should be subject to broad public consultation before it is reported by the Advisory Committee to the Human Rights Council. This presupposes that the draft Declaration will be translated into English, French and Spanish at a minimum and preferably into all official UN languages prior to circulation for comment.

Diante ao exposto, as organizações que alertaram para esta "falha", informaram que seus comentários seriam concentrados no conteúdo e na inclusão ou exclusão de temas, e não na linguagem do texto. Sem embargo, outros relatórios trouxeram variadas sugestões de inclusão ou exclusão de termos significativos e, muitos, em especial sugerem que o texto carecia de clareza em certos pontos a serem reexaminados pelo Comitê Consultivo ${ }^{213}$.

\subsection{Conclusão dos trabalhos}

Uma vez tendo o ouvido os participantes em dois momentos - para o anteprojeto e o projeto - o Comitê Consultivo conclui os trabalhos iniciados em janeiro de 2010 quando submete o projeto de DEFDH ao Conselho de Direitos Humanos que é aprovado sem votações, em 29 de janeiro de $2010 .^{214}$

O projeto do Comitê contava com 43 artigos distribuídos em (i) definições e princípios; (artigos 1 a 15); (ii) medidas de aplicação no plano interno (artigos 16 a 32) e (iii) medidas de aplicação no plano internacional (artigos 33 a 43), sem alterações significativas.

Em sua $13^{\mathrm{a}}$ Sessão, o Conselho testemunhou uma discussão do mais alto nível sobre o projeto submetido pelo Comitê Consultivo, decidindo, além de aprovar o projeto de DEFDH, criar um grupo de trabalho de composição aberta ${ }^{215}$, através da adoção da

\footnotetext{
${ }^{212}$ Comentaram a este respeito: International Indian Treaty Council, Soka Gakkai International - UN Liaison Office e a Anistia Internacional.

${ }^{213}$ É o caso dos relatórios de Human Rights Education Associates (HREA), Soka Gakkai International e ONU.

${ }^{214}$ Pela comunicação 4/2 (documento A/HRC/AC/4/4).

215 Tradução do autor para Open-ended working group.
} 
Resolução 13/15 para negociar, finalizar e submeter ao Conselho, o projeto final da DEFDH com base no documento elaborado por Decaux e sua equipe, reportando as conclusões antes de sua XVI Sessão. Essa iniciativa foi incentivada pela Plataforma de Educação em Direitos Humanos que, além dos cinco dias de trabalho programados para janeiro de 2011, decide estabelecer três períodos de consultas informais ${ }^{216}$ acerca do texto submetido pelo Comitê Consultivo, assim programados: (i) em 24 de junho para receber os comentários gerais; (ii) em 3 de setembro para comentários e contribuições específicas e (iii) em 14 de dezembro para analisar a primeira versão preparada pela Plataforma.

O grupo de trabalho nomeou Jurg Lauber como seu presidente-relator que, após a sessão informal de 3 de setembro, exprime o consenso sobre a longa extensão do projeto preparado pelo Comitê, dessa maneira "les efforts du Pôle ont été dirigés afin de parvenir à un texte plus court et plus compact, sans cependant perdre les éléments de substance qui figurent dans le texte du Comité consultatif".

Após a sessão de dezembro, o grupo de trabalho volta a trabalhar na revisão do texto, agora com base na primeira versão de sua autoria e ouvidos os comentários do grupo de trabalho. No terceiro encontro, em dezembro de 2010, aproximadamente 30 estadosmembros e diversas ONGs estiveram presentes e leram, artigo por artigo, o primeiro projeto da DEFDH preparado pela Plataforma, já muito mais enxuto que o documento preparado pelo Comitê.

Estas consultas informais foram de grande importância para a busca de consenso sobre o conteúdo da DEFDH, nas palavras do presidente do grupo de trabalho, "me renforcent dans la conviction que nous pouvons atteindre un consensus sur le projet de déclaration (...)"

Após esse período, a Plataforma submete o seu projeto de DEFDH que é aprovado pelo Conselho de Direitos Humanos, sem votação, em 23 de março de $2011 .^{217}$

Finalmente, após um período de analise do conteúdo, a DEFDH, através da Resolução 66/137, é adotada sem votação pela Assembleia Geral em 19 de dezembro de 2011, entrando em vigor imediatamente. A Declaração na íntegra é parte desta obra, figurando no anexo II. ${ }^{218}$

\footnotetext{
${ }^{216}$ Em 24 de junho, 3 de setembro e 14 de dezembro de 2010.

${ }^{217}$ Conforme anexo da Resolução $16 / 1$

${ }^{218}$ Cf. p. 176
} 


\title{
Capítulo 3
}

\section{A Declaração das Nações Unidas sobre a Educação e Formação em Direitos Humanos.}

\author{
Enfim, a DEFDH.
}

Primeiramente, importante ressaltar o processo de elaboração (coletivo e participativo) visando a busca por consenso na comunidade internacional. Além de atender aos anseios por mais participação - especialmente das ONGs internacionais - é um meio pelo qual a retórica de um documento internacional é elaborada em conjunto, otimizando o tempo entre a elaboração e as deliberações sobre sua aprovação.

A Plataforma desempenhou competente trabalho de concisão em resumir o projeto de DEFDH sem perder o conteúdo essencial, no entanto, alguns elementos importantes restaram, ou prejudicados com essa nova redação, ou ainda, foram excluídos do projeto final do Comitê Consultivo. Em sua versão final, a DEFDH apresenta apenas 14 artigos, ou seja, 29 artigos a menos que o texto do Comitê. A supressão de alguns elementos serão comentadas sempre que pertinente dentro da analise do texto final.

A DEFDH, como de costume, traz em seu preâmbulo um repasse histórico do processo construtivo deste direito, ou seja, reafirma os propósitos e princípios da Carta da ONU de promover e fomentar o respeito de todos os direitos humanos "sin distinción por motivos de raza, sexo, idioma o religión”, responsabiliza os indivíduos bem como as instituições por promover esse respeito através da educação, recorda as obrigações dos Estados frente a outros documentos (DUDH, PIDESC e outros), ratifica o valor da educação e o chamamento da Conferencia de Viena para

$$
\begin{aligned}
& \text { (...) que incluyeran los derechos humanos, el derecho humanitario, la } \\
& \text { democracia y el imperio de la ley como temas de los programas de estudio de } \\
& \text { todas las instituciones de enseñanza y afirmando que la educación en materia de } \\
& \text { derechos humanos debe abarcar la paz, la democracia, el desarrollo y la justicia } \\
& \text { social (...) }
\end{aligned}
$$

Afirmando, outrossim, que a EDH deve "favorecer la comprensión, la tolerancia y la amistad entre todas las naciones y todos los grupos raciales étnicos o religiosos" fundamentais para promover o desenvolvimento da ONU e para "el mantenimiento de la paz, la seguridad y el fomento del desarrollo y de los derechos humanos."

Por fim, relembra o documento final da Reunião de Cúpula Mundial de 2005 em que os chefes de Estado se comprometem em dar atenção às iniciativas educacionais em EDH 
especialmente a continuidade do Programa Mundial de Educação em Direitos Humanos.

Este ultimo elemento é de suma importância em nosso entender. A DEFDH não vem para substituir nenhuma normativa ou programas em marcha mas sim para contribuir com eles e para, sobretudo, positivar nitidamente a EDH nas normativas internacionais. Dessa forma, a DEFDH ratifica o processo de educação internacional de EDH já em andamento.

Esse movimento internacional da EDH é expressado no próprio texto da DEFDH, na letra do artigo 12, $\S 1^{\circ}$, que afirma que "la cooperación internacional a todos los niveles debe respaldar y reforzar las actividades nacionales, incluidas, cuando corresponda, a nivel local, dirigidas a impartir educación y formación en materia de derechos humanos." Para isso o $\S 2^{\circ}$ do mesmo artigo determina que a eficácia da EDH é obtida pela complementariedade e coordenação das atividades em nível internacional, regional, nacional e local, e, “debe alentarse la financiación voluntaria de proyectos e iniciativas en la esfera de la educación y la formación en materia de derechos humanos" (em seu $\S 3^{\circ}$ ). Esta cooperação internacional envolve a ONU e suas agencias especializadas, as organizações internacionais e regionais - de direitos humanos ou não - interagindo com os Estados e suas politicas nacionais de EDH.

A ONU, as organizações internacionais e regionais, além do dever de impartir educación y formación en materia de derechos humanos a su personal civil, así como al personal militar y policial que preste servicios con arreglo a sus mandatos - (conforme determina o artigo 11), têm a incumbência de incluir a EDH em seus trabalhos e de observar o conteúdo dos informes apresentados pelos Estados no tocante à ela ${ }^{219}$.

A cooperação internacional é necessária para superar dificuldades para implementação de programas de EDH. O governo senegalês, por exemplo, foi enfático ao dizer que os esforços para a EDH já são empregados, no entanto, é necessário "un appui de la communauté internationale aux pays en développement pour mieux pendre en charge cette question". Ele, entre outros tantos, sugere que a Declaração destaque a importância da cooperação internacional para o avanço da $\mathrm{EDH}^{220}$.

A necessidade de apoio internacional é devido: (i) à falta de qualificação técnica sobre a EDH em países com pouca tradição no estudo desta matéria - por esta razão, o Conselho da Europa sugere que a cooperação internacional, particularmente, a regional,

${ }^{219}$ DEFDH Artigo $13, \S \S 1^{\circ} \mathrm{e} 2^{\circ}$.

${ }^{220}$ Estado marroquino: "A titre indicatif, on peut souligner l'importance de mettre l'accent sur la coopération internationale et l'échange d'expérience en matière de formation et d'éducation aux droits de l'Homme." 
deve ser promovida como um modo de apoiar e motivar defensores e educadores; e (ii) à falta de recursos financeiros. ${ }^{221}$

Em se tratando de cooperação internacional, entendemos serem predominantes algumas modalidades, tais quais: (i) Assistência intergovernamental; (ii) Assistência sistema internacional ou regional e governo nacional; (iii) Sociedade civil internacional (principalmente as ONGs) e governos nacionais.

A falta de pessoal capacitado para a EDH não é exclusividade de países em desenvolvimento e com pouca tradição na matéria, mas é apontada como uma dificuldade também pelas organizações internacionais ${ }^{222}$.

Os órgãos de tratados também não ficaram de fora, no entanto, os redatores da DEFDH, mui acertadamente, optaram por chamar genericamente a categoria de mecanismos internacionales y regionales, onde se incluem não apenas os órgãos já referidos, mas também os órgãos regionais e outros ${ }^{223}$, além do próprio Conselho de Direitos Humanos ${ }^{224}$. No entanto, a redação desagradou a muitos colaboradores por não haver uma obrigação clara para a inclusão da EDH nos relatórios do Exame Periódico Universal. ${ }^{225}$ Ainda sobre isto, a sugestão da Anistia Internacional, entre outras, não foi acolhida pela Plataforma de se incluir um paragrafo no preambulo que convocasse mais uma vez os países a assinarem e ratificarem todos os instrumentos internacionais de direitos humanos. De fato, a falta de ratificação não gera obrigação internacional do Estado o que impede o avanço do processo internacional da EDH.

Neste capítulo, analisaremos, primeiramente, os atores envolvidos nos processos educacionais de EDH passando para a analise da definição construída durante o processo de elaboração do texto final.

\footnotetext{
${ }^{221}$ Ambas previstas no $\S 3^{\circ}$ do Artigo $7^{\circ}$ da DEFDH.

${ }^{222}$ Alguns relatórios das organizações internacionais demonstravam sua capacidade para formar seu pessoal, ou mesmo promover programas de EDH, porém somente no direito específico objeto de seu mandato. É o caso da FAO, UNFPA, OMS e ACNUR. Este último, por exemplo, lamenta que não tenha sido possível treinar seu pessoal em direitos humanos em geral, uma vez que a limitação de recursos é absorvida pela necessidade de capacitar seu pessoal especificamente através de workshops sobre temas como o principio do non-refoulement, ou mais genericamente sobre os procedimentos especiais e resoluções como instrumentos para advocacy.

${ }^{223} \mathrm{DEFDH}$, artigo $13, \S 1^{\circ}$ : Los mecanismos internacionales y regionales de derechos humanos deben, conforme a sus respectivos mandatos, tener en cuenta en su trabajo la educación y la formación en materia de derechos humanos.

${ }^{224}$ Idem, $\S 2^{\circ}$ : Se alienta a los Estados a que incluyan, cuando proceda, información sobre las medidas adoptadas en el ámbito de la educación y la formación en materia de derechos humanos en los informes que presenten a los mecanismos pertinentes de derechos humanos.

${ }^{225}$ é o caso da ONG CIFEDHOP (Centre international de formation pour l'enseignement des droits de l'homme et de la paix), entre outras. No entanto, pressões de alguns países, em especial a Rússia, pediam a supressão deste dispositivo.
} 
Em seguida, analisaremos os elementos necessários para a satisfação da EDH através de uma estratégia bem definida envolvendo a participação de todos os atores., conforme dispõe o artigo $8^{\circ}, \S 2^{\circ}$ :

En la concepción, aplicación, evaluación y seguimiento de las estrategias, los planes de acción, las políticas y los programas deben participar de todos los interesados pertinentes, entre otros el sector privado, la sociedad civil y las instituciones nacionales de derechos humanos, alentando, según corresponda, las iniciativas de múltiples interesados.

\subsection{Uma ação em conjunta: os atores envolvidos}

Durante o processo de elaboração do retórica da DEFDH, diversos atores envolvidos no processo educacional foram listados, vale dizer: (i) a ONU; (ii) as organizações internacionais e regionais; (iii) os Estados; (iv) as instituições da sociedade civil (em particular as ONGs, os defensores de direitos humanos e o setor privado); (v) a comunidade local; (vi) a comunidade educativa; (vii) a família, e (viii) os meios de comunicação. Esses atores foram expressos na DEFDH no artigo $10, \S 1^{\circ} .^{226}$

Além da participação dos organismos que compõem o sistema ONU dos direitos humanos e as organizações internacionais em geral, outros atores envolvidos neste processo serão analisados, sendo sem duvidas, rendida maior atenção ao Estado por ser ele o maior responsável pela educação e pela EDH.

\subsubsection{Responsabilidade do Estado}

Conforme observamos em diversas oportunidades ao longo desta dissertação, a EDH é responsabilidade maior do Estado por promover e garantir a EDH en un espíritu de participación, inclusión y responsabilidad. ${ }^{227}$ Referido espirito de participação é esclarecido no paragrafo seguinte que expressa que los Estados deben crear un entorno seguro y propicio para la participación de la sociedad civil, el sector privado, y otros interesados pertinentes, protegendo integralmente os direitos humanos e liberdades

\footnotetext{
${ }^{226}$ DEFDH, artigo 10, § 1: Diversos actores sociales, como, entre otros, las instituciones educativas, los medios de comunicación, las familias, las comunidades locales, las instituciones de la sociedad civil, en particular las organizaciones no gubernamentales, los defensores de derechos humanos y el sector privado son importantes para promover e impartir educación y formación en materia de derechos humanos. E § 2: Se alienta a las instituciones de la sociedad civil, al sector privado y a otros interesados pertinentes a velar por que su personal reciba educación y formación adecuadas en materia de derechos humanos.

${ }^{227}$ Conforme artigo $7^{\circ}$, $\S 1^{\circ}$ : Los Estados y, según corresponda, las autoridades gubernamentales competentes, son los principales responsables de promover y garantizar la educación y la formación en materia de derechos humanos, concebidas e impartidas en un espíritu de participación, inclusión y responsabilidad.
} 
fundamentais destes atores.

Primeiramente, a educação (de qualquer tipo e índole) é necessária para a socialização, característica fundamental das sociedades humanas organizadas. A socialização é o processo que

\begin{abstract}
“(...) assegura que todos os novos membros saibam como deles participar. Em sistemas mais simples, esse treinamento pode ser feito informalmente. Em sistemas mais complexos, como as sociedade industriais, o volume de conhecimentos necessários é tão grande e diversificado que treinamento formal, sistemático, torna-se necessário. ${ }^{228}$
\end{abstract}

Naturalmente, as escolas são as instituições encarregadas de ministrar a educação que, por ser um direito do individuo, passa a ser um dever do Estado, e, sobretudo, por ser um direito social, é obrigação e responsabilidade dele, o seu cumprimento. O Estado não deve, neste caso, respeitar ou proteger os direitos. Mas sim, promove-los ${ }^{229}$ através de investimentos públicos para que todo o processo educacional se desenvolva. Ou seja, tratase de uma obrigação positiva.

Mas além, a escola pública, além de ser o único meio para garantir o acesso à educação para todos, é, sobretudo, o ideal da EDH. Não parece exagero supor que se a EDH se desenvolver em seu ideal, permeando toda a sociedade, o que pedimos licença para a pequena elucubração onírica, a escola publica é a única que resistirá. Certamente é na escola pública que o principio da igualdade um dia se materializará em realidade.

(...) a escola pública é um locus privilegiado pois, por sua própria natureza, tende a promover um espírito mais igualitário, na medida em que os alunos, normalmente separados por barreiras de origem social, aí convivem. Na escola pública o diferente tende a ser mais visível e a vivência da igualdade, da tolerância e da solidariedade impõe-se com maior vigor. O objetivo maior desta educação na escola é fundamentar o espaço escolar como uma verdadeira esfera pública democrática ${ }^{230}$.

A escola privada, atualmente, acaba por ser um mal necessário em muitos países: se todos frequentassem a escola pública, maiores os investimentos neste setor o que contraria o pensamento administrativo dos orçamentos públicos baseado em modelos empresariais. A alegação que não é possível garantir a todos uma educação igualitária e de qualidade é desmentida pela experiência de Cuba a este respeito. Contudo, e escola privada cria uma casta (as crianças somente se relacionam com as do mesmo nível social). A mensalidade, dessa maneira, serve como passaporte para adentrar a este "clube" privativo. E esse movimento anda em plena expansão.

\footnotetext{
${ }^{228}$ JOHNSON, 1997, p 81.

${ }^{229}$ A natureza das obrigações: promover, respeitar, proteger e cumprir.

${ }^{230}$ BENEVIDES, 2009, p. 327.
} 
A responsabilidade do Estado em relação à educação não é uma inovação da DEFDH, porquanto a própria DUDH já impunha esta obrigação ${ }^{231}$, além dos outros documentos pertinentes posteriores a ela, como os Pactos, a Declaração de Jomtien, as Metas de Desenvolvimento do Milênio, etc.

Uma vez que a educação é desenvolvida em nível nacional, a DEFDH dedicou 4 artigos dos seus 4 diretamente à função do Estado, com vistas à implementação da EDH. Para dar mais ênfase à retorica desta obrigação geral, a ONU (através do METU) e a Anistia Internacional haviam sugerido que os artigos que tratassem das responsabilidades

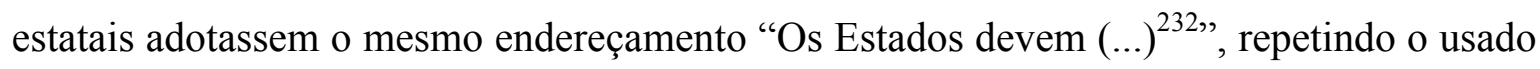
em outros instrumentos como a Declaração sobre os Direitos e Responsabilidades dos Indivíduos, Grupos e Órgãos da Sociedade de Promover e Proteger os Direitos Humanos e Liberdades Fundamentais Reconhecidos Universalmente ${ }^{233}$. Esta sugestão não foi acolhida, entretanto.

Propugna ainda, a DEFDH, que os Estados, de igual sorte à ONU e as organizações internacionais, deve garantir a formação adequada em EDH - contendo o Direito Internacional Humanitário e o Direito Penal Internacional - de seus servidores públicos, dos magistrados, os agentes da ordem e as forças armadas, conforme dispõe o $\S 4^{\circ}$, do artigo $7^{\circ}$, que inclui também a formação “adecuada en materia de derechos humanos de maestros, formadores, educadores y personal privado que desempeñe funciones de los poderes públicos. A redação do artigo $7^{\circ}$ incomoda por dois motivos.

Ao longo de todo o processo coletivo de elaboração da DEFDH dois elementos tiveram sua importância repetida reiteradamente: o defensor dos direitos humanos e o professor. Por optar por um documento bem mais conciso, a Plataforma viu-se obrigada a reunir diversos elementos que antes estavam separados (muitos em artigos próprios). No caso do artigo $7^{\circ}$, os redatores reuniram 7 elementos antes considerados autônomos: (i) um ambiente seguro, (ii) participativo, (iii) em que se proteja todos os envolvidos no processo, (iv) utilizando-se do máximo dos recursos disponíveis; e (v) a formação adequada dos servidores públicos, incluindo-se na mesma categoria, (vi) os magistrados, agentes da ordem, forças armadas e (vii) os professores.

\footnotetext{
${ }^{231}$ A educação, de acordo com $\S 1^{\circ}$ do artigo 26 da DUDH e sua eficácia: Meta do Desenvolvimento do Milênio; A EDH como direito humano de acordo com o $\S 2^{\circ}$ do artigo 26 da DUDH;

${ }^{232}$ Em inglês "The States shall..."

${ }^{233}$ Declaration on the Right and Responsibility of Individuals, Groups and Organs of Society to Promote and Protect Universally Recognized Human Rights and Fundamental Freedoms (Resolução da Assembleia Geral 53/114 de 9 de dezembro 1998).
} 
Entendemos que colocar os professores e os outros servidores públicos em um só artigo acabou por diminuir a importância da figura do professor como também a do defensor dos direitos humanos. Estas duas figuras na verdade se confundem, podendo ser o professor o defensor dos direitos humanos, como o podem ser também os educadores, ativistas, advogados, sociólogos, assistentes sociais, psicólogos, antropólogos, líderes comunitários, paralegais, representantes de ONGs, de organizações internacionais, de movimentos eclesiásticos, etc., principalmente aqueles que desenvolvem trabalho no terreno, em locais desprivilegiados ou em locais sob regime autocrático, que são frequentemente alvos de prisões arbitrárias, ameaças, sequestros, desaparecimentos, assassinatos, em diversas partes do mundo ${ }^{234}$.

A figura do defensor dos direitos humanos foi prejudicada no processo de concisão. Esta havia sido uma recomendação marcante nos questionários de consulta submetidos ao Comitê Consultivo que pretendiam a inclusão de algum tipo de mecanismo especial de proteção dos defensores dos direitos humanos ${ }^{235}$. Por exemplo:

Just don't forget to include protections for human rights educators. In Burma, some of those I've trained are being sentenced to prison for the crime of teaching the Universal Declaration of Human Rights. ${ }^{236}$

O que ocorre também com participantes sírios que encontram problemas por participarem no EMHRN Summer Schools ${ }^{237}$. Então, se a formação e capacitação dos professores, por exemplo, é essencial para um bom programa de EDH, garantir sua segurança é condição sine qua non.

Apesar de não dedicar um artigo ou paragrafo exclusivo aos defensores dos direitos humanos (como fez o texto do Comitê), a figura do defensor aparece no artigo $7^{\circ}, \S 2^{\circ}$ :

Los Estados deben crear un entorno seguro y propicio para la participación de la sociedad civil, el sector privado y otros interesados pertinentes en la educación y la formación en materia de derechos humanos, en que se protejan integramente los derechos humanos y las libertades fundamentales de todos,

\footnotetext{
${ }^{234}$ Nesta esteira segue a colaboração da ONG Tsara Manazoa: Une Loi ou une protocole additionnelle doivent être instaurées dans chaque Etats Partis pour instituer la défense des Défenseurs de droit de l'homme. Pour Madagascar, plusieurs associations de droit de l'homme sont reconnues mais qui n'arrivent pas à faire valoir vraiment un contre poids face à l'appareil administratif de la raison de l'Etat.

${ }^{235}$ Atenta ao problema da violência contra os defensores de direitos humanos, a ONG Mouvement pour la Défense de l'Humanité et l'Abolition de la Torture (MDHAT), expressa: "La futur déclaration sur l'éducation et la formation des droits de l'homme devrait prévoir voir renforcer la protection, les droits et la sécurité, ainsi que la promotion du bien être physique et morale du promoteur et des activistes."

${ }^{236}$ CLAUDE, Richard Pierre. Em correio eletrônico enviado ao grupo de discussão Global HRE List mantida por HREA, Disponível em http://www.hrea.org/lists2/list_messages.php?id=29. Acessado em 07.01.2012.

${ }^{237}$ HEMICI, Nour. Em correio eletrônico enviado ao grupo de discussão Global HRE List mantida por HREA, Disponível em http://www.hrea.org/lists2/list_messages.php?id=29. Acessado em 07.01.2012.
} 
incluidos los que participan en el proceso. (grifo nosso).

Sobre a formação de servidores públicos em EDH, a DEFDH condensou todos num mesmo paragrafo. Se por um lado, ganhou-se na concisão, de outro, entendemos que pecou a DEFDH. Não se trata da mesma categoria de formação. Sem embargo, fica defendida a EDH para todos os servidores sobre os temas dos direitos humanos, Direito Internacional Humanitário e Direito Penal Internacional

A obrigação do Estado de formar seus agentes da ordem pública ${ }^{238}$ em EDH é fundamental para que os serviços prestados e executados pelo Estado levem sempre em consideração os direitos humanos, conforme recomendação frequente, entre tantas, a do governo de Burkina Faso ${ }^{239}$. O Estado francês havia sugerido, mais além, que essa obrigação deveria constar já no preâmbulo da $\mathrm{DEFDH}^{240}$. Ainda a este respeito, outra sugestão não acatada pela DEFDH era a de incluir a EDH como parte integrante do treinamento inicial do servidor (pre service training), antes mesmo de iniciarem a exercer suas funções ${ }^{241}$.

Importante recordar que historicamente o Estado foi e continua sendo o maior violador dos direitos humanos. Fazer com que o conhecimento sobre os direitos humanos chegue aos agentes da ordem publica é fundamental para combater, entre tantos problemas, a violência. Um exemplo claro que testemunhamos atualmente é o fenômeno que ocorre no México no combate ao trafico de drogas.

\footnotetext{
"Instead of reducing violence, Mexico's 'war on drugs' has resulted in a dramatic increase in killings, torture, and other appalling abuses by security forces, which only make the climate of lawlessness and fear worse in many parts of the country, "242
}

Não se trata do mesmo treinamento para professores e militares, por exemplo. O treinamento sobre o direito humanitário é muito pertinente às forças armadas, em especial aqueles que compõe as forças de paz internacionais ${ }^{243}$, não sendo imprescindível para a

\footnotetext{
${ }^{238}$ Incluindo os magistrados, as polícias, os agentes penitenciários, as forças armadas.

${ }^{239}$ L'éducation et la formation en droits de l'Homme doit se faire au bénéfice de tous les citoyens mais surtout des groupes socioprofessionnels tels les forces de l'ordre qui sont détenteurs du pouvoir de contraindre.

240 'L'education et la formation aux droits de l'homme participent non seulement des pré-requis à l'organisation d'une vie sociale régulée mais correspond aussi et san conteste à un levier de progression et d'efficacité des sociétés et plus spécifiquement, des autorités et professionnels qui, en leur sein, sont dépositaires de l'autorité de l'Etat et des prérogatives de contrainte légitime".

${ }^{241}$ Sugestão do instituto austríaco Ludwig Boltzmann.

${ }^{242}$ Informou José Miguel Vivanco, diretor para as américas da ONG Human Rights Watch. Disponível em http://www.hrw.org/news/2011/11/09/mexico-widespread-rights-abuses-war-drugs. Acessado em 07.01.2011.

${ }^{243}$ Os militares brasileiros que servem no Haiti através do MINUSTAH, por exemplo.
} 
formação do professor. Este, em nosso entender, foi a figura mais prejudicada com a redação deste artigo. No texto do Comitê, a formação de professores era redigida em artigo autônomo $^{244}$, garantido mais atenção à classe ${ }^{245}$. E quão necessário é dar atenção à classe. Veremos que a desvalorização do professor atende a interesses maiores de manutenção do sistema social vigente, excluidor e opressor.

Por se tratar de uma obrigação do Estado garantir o ensino público gratuito primário, são necessários professores públicos, e, para a implementação da EDH nos sistemas educacionais públicos, professores públicos treinados e capacitados para tanto. Esta posição foi reiterada na vasta maioria dos relatórios recebidos pelo Comitê ${ }^{246}$. O Canadá e o Chipre colocam a capacitação dos professores como suas prioridades no processo de avanço da EDH. O governo canadense, ademais, informou que seu objetivo é capacitar professores para a educação sobre, para e por aborígenes. Ou seja, seu plano é capacitar professores aborígenes sobre a EDH para que esses possam agir como multiplicadores.

A centralidade dos professores e educadores para projetos de EDH deveriam ser enfatizadas com referência à importância de seus níveis de conhecimento sobre os direitos humanos e suas atitudes em relação a eles, aponta a Comissão de direitos humanos Irlandesa.

Outro tema fundamental que restou prejudicado é o do investimento financeiro. A redação do $\S 3^{\circ}$ do artigo $7^{\circ}$ determina que os Estados devem adotar medidas para garantir “hasta el máximo de los recursos de que dispongan, la aplicación progresiva de la educación y la formación en materia de derechos humanos a través de los medios adecuados, entre otras cosas mediante la adopción de políticas y medidas legislativas y administrativas." Menciona essa obrigação também de maneira genérica no ultimo artigo (14) da DEFDH: "Los Estados deben adoptar medidas adecuadas para velar por la aplicación eficaz y el seguimiento de la presente Declaración y facilitar los recursos necesarios para ello."

Naturalmente a EDH - por ser um direito social - sofre dos mesmos males inerentes à

\footnotetext{
${ }^{244}$ Projeto de DEFDH elaborado pelo Comitê consultivo, artigo 29: El progreso de la educación y la formación en derechos humanos se nutre de la formación inicial y permanente de los docentes en todos los niveles educacionales, así como de la investigación teórica y práctica, en las esferas de las ciencias de la educación y la pedagogía y de la normativa internacional de derechos humanos, gracias a la cooperación y el establecimiento de redes entre los institutos especializados y los centros de investigación, con miras a favorecer la definición de los conceptos comunes y los métodos pedagógicos.

${ }^{245}$ Voltaremos ao tema no capitulo 4 quando tratarmos da desigualdade social.

${ }^{246}$ Argélia, Tunísia e Chipre, Áustria, Armênia, Canadá, INDH irlandesa, A Universidade de Gotemburgo, ONG italiana Istituto Internazionale Maria Ausiliatrice, para citar alguns.
} 
efetivação desta classe de direitos. Diferentemente do que sugeriu a ONG CIFEDHOP ${ }^{247}$, por exemplo, a "disponibilidade de recursos" acabou por constar da DEFDH. A sugestão deu-se por entender esta ONG ser a EDH uma obrigação autônoma e não sujeita à disponibilidade financeira. O tema do "hasta el máximo de los recursos de que dispongan" em relação à alocação de orçamentos públicos destinados à implementação da EDH foi frequente nos relatórios recebidos pelo Comitê. A UNICEF, por exemplo, afirmou ser indispensável o investimento social público em EDH. A falta de recursos foi indicada pela maioria dos participantes como sendo a grande barreira para a promoção do direito à $\mathrm{EDH}^{248}$, uma vez que, segundo o Estado turco, a EDH requer investimento constante e permanente e esses fundos nem sempre estão disponíveis ${ }^{249}$. Novamente, observa-se que o problema não é exclusivo de países em desenvolvimento, como aponta a INDH canadense: "like its provincial and territorial counterparts, the Canadian Human Rights Commission faces resource and funding challenges."

O problema de não haver uma definição clara da obrigação estatal do investimento financeiro em $\mathrm{EDH}$ é o fato dele estar submetido a cortes na primeira crise financeira que aparece. A crise econômica mundial iniciada em 2008, por exemplo, foi comentada pela INDH irlandesa com grande preocupação, já que a redução dos gastos públicos acaba por esvaziar projetos como são os de $\mathrm{EDH}^{250}$. Por esta razão, a Declaração deveria, segundo estes participantes, promover a priorização dos recursos nacionais para a $\mathrm{EDH}^{251}$.

Nesta mesma esteira, a retórica da DEFDH também foi menos enfática sobre as medidas a serem adotadas. As tentativas anteriores falavam em criação de medidas legislativas e adoção de politicas (previa até a inclusão do termo "boa vontade politica")

\footnotetext{
${ }^{247}$ Centre international de formation pour l'enseignement des droits de l'homme et de la paix.

${ }^{248}$ Por exemplo: Governo de Mauricio, INDH Guatemalteca e Canadense.

${ }^{249}$ Soka Gakkai International: The perennial inadequacy of financial resources has been a major obstacle for civil society in its efforts to promote and implement human rights education and training. The declaration should contain a provision of assurance of access to financial resources. It could, for example, stipulate the responsibility of governments to include human rights education and training in annual national budgetary planning. The declaration could also stipulate such a responsibility within the UN system as international cooperation and assistance for implementation of the right to human rights education and training at the global level.

250 Segungo ela: "The recent economic downturn has seen a decrease in State expenditure in education and human rights education, and a decrease in funding allocated to the existing national human rights infrastructure (...) several key support services for citizenship and human rights education have had to reduce their services due to reductions in funding.

${ }^{251} \mathrm{O}$ melhor exemplo da frustração causada pela alegada falta de recursos públicos disponíveis para investimento em EDH, foi trazido pela INDH jordaniana ao se mostrar desapontada pela falta de recursos disponíveis para a implementação de seu plano nacional de EDH, estimado, segundo ela, em aproximadamente dois milhões de dólares, quantia nada significativa em termos de orçamentos públicos, especialmente para um país como a Jordânia.
} 
especificas para a EDH, como havia sugerido a UNICEF - que entende que o primeiro passo para o estabelecimento de uma política nacional de EDH é o apoio e a advocacy para uma reforma legislativa sobre o tema, caso seja necessária. Esta necessidade mostra-se fundamental uma vez que

Las políticas insensibles a la protección de los niños y las niñas y las necesidades especiales de las personas jóvenes y adultas que viven en el analfabetismo, por ejemplo, agravan la exclusión de casi mil millones de personas a quienes actualmente se niega el derecho humano a la educación. ${ }^{252}$

Como pôde ser observado pelas respostas aos questionários, a EDH não consta positivada realmente da maioria das legislações nacionais sobre a educação ou sobre os direitos humanos. O governo da Áustria, por exemplo, é um dos poucos que informa já ter superado esta fase e que as medidas surtiram efeito sendo que atualmente a Áustria já conta, inclusive, com um centro especializado em EDH ligado ao Ministério da Educação $^{253}$, estabelecidas por força de lei.

Por outro lado, a DEFDH não deixou de reafirmar o importante papel das INDHs para a promoção dos direitos humanos ${ }^{254}$, convocando os Estados a criarem, implementarem ou avançarem no seu papel, seguindo os princípios de Paris ${ }^{255}$, consoante seu artigo $9^{\circ}$ :

Los Estados deben fomentar la creación, el desarrollo y el fortalecimiento de instituciones nacionales de derechos humanos eficaces e independientes, conforme a los Principios de París, reconociendo que esas instituciones pueden desempeñar un papel importante, incluida, si fuera necesario, una función de coordinación, en la promoción de la educación y la formación en materia de derechos humanos al concienciar y movilizar a los agentes públicos y privados pertinentes, entre otras cosas.

As INDHs, dessa forma, despontam como órgão favorito da DEFDH para elaborar os planos nacionais de EDH, em detrimento aos ministérios de educação, comissões dependentes, secretarias especiais, etc. Assim sendo, a DEFDH renova o chamamento aos Estados a criar ou incrementa-las. A necessidade da elaboração dos planos nacionais de educação é um reforço ao compromisso pretendido pelo Programa Mundial de Educação em Direitos Humanos. Conforme redação do $§ 1$ do artigo $8^{\circ}$ da DEFDH:

\footnotetext{
${ }^{252}$ MUÑOZ, Vernon. El mar entre la niebla: el camino de la educación hacia los derechos humanos. Costa Rica: Luna Hibrida Ediciones, 2009. p. 7.

${ }^{253}$ Federal Ministry of Education's service centre for human rights education.

${ }^{254}$ Neste sentido, expressa a Soka Gakkai: Regarding article 8 on national human rights institutions (NHRIs), while Member-States recognised the importance of the role of NHRIs for human rights educatin and training, they pointed out the absence of NHRI in many countries and the need to properly formulate the language.

${ }^{255}$ Irish Human Rights Commission: A declaration on human rights education and training needs to clearly include the important role of National Human Rights Institutions in this area.
} 
Los Estados deben formular o promover la formulación, al nivel adecuado, de estrategias y políticas y, según corresponda, planes de acción y programas, para impartir educación y formación en materia de derechos humanos, por ejemplo integrándolas en los planes de estudios de las escuelas y en los programas de formación. A ese respecto, deben tener en cuenta el Programa Mundial para la educación en derechos humanos y las necesidades y prioridades locales y nacionales especificas.

Dos elementos que devem constar destes planos nacionais, trataremos no final deste capitulo em "Estratégias para a efetivação" .

\subsubsection{Outros atores envolvidos}

A família tem status privilegiado e responsabilidade primária sobre a EDH das crianças, e, portanto, valor fundamental para educação e a EDH desde a DUDH, que expressa em seu artigo 26, $\S 3^{\circ}$ que "Aos pais pertence a prioridade do direito de escolher o gênero de educação a dar aos filhos". Em sua ausência, há que se pensar em alternativas para iniciar a EDH ${ }^{256}$, sugeriu a ONG Association Points-Coeur. Essa sugestão, combinada com a do Departamento de Educação da universidade sueca de Gotemburgo - que requereu que fosse incluso, além do acesso de toda a criança à pré-escola (Early Childhood Education), a preparação de professores para esta instância da educação porque, segundo eles, é a qualidade do professor que faz a diferença na qualidade da pré-escola. Estas sugestões resultaram na inclusão da pré-escola no artigo $3^{\circ}, \S 2^{\circ}$ (sobre a educação em todos os níveis).

Por seu turno, a comunidade local também desempenha papel fundamental para a EDH, reconhece a DEFDH. É nela que a educação se desenvolve e por esta razão ela deve dar continuidade ao conhecimento e princípios adquiridos pelas crianças nas escolas. Para tanto, é necessário que os membros da comunidade local também passem por este processo educacional para que seja possível estabelecer a tão almejada cultura dos direitos humanos.

Educating about human rights teaches about human rights while working to protect those very rights and encourages learners to form their own opinions and beliefs and then act on those beliefs, therefore, human rights education and training is a much needed service within the community. The use of human rights education in schools will promote knowledge of and respect for the rights contained in the Universal Declaration of Human Rights and teaches the values of human dignity, tolerance and multi-culturalism. ${ }^{257}$

A comunidade local não é um sujeito, mas sim um locus onde vivem vários sujeitos: as pessoas que compõem o comercio, a segurança, o transporte, os agentes do Estado em

256 Estamos falando de EDH no sistema pré-escolar.

${ }^{257}$ ONG The Centre on Human Rights for People with Disabilities, Disability Action, Belfast, Northern Ireland. 
geral. A comunidade local naturalmente envolve os governos locais. Estes se vêm longe das obrigações internacionais assumidas pelos Estados nacionais, mas, por estarem mais próximos da vida cotidiana das pessoas, são inescapavelmente, importantes para o processo de $\mathrm{EDH}^{258}$.

A família e a comunidade local são o entorno mais próximo do educando. São, desta maneira, cernes da educação e, por conseguinte, da EDH, pelo fato do derecho a la educación no se reduce a la experiencia pedagógica, puesto que implica todo aquello que, estando mas allá o - o mas acá - de la escuela, incide definitivamente en ella. ${ }^{259}$

Muito se tem falado e escrito sobre as novas tendências da família na atualidade e da falta de cuidados familiares em vários contextos e extratos da população.

Quais os obstáculos para efetivar uma cultura de direitos humanos na família, na comunidade local e na sociedade? Foram desafios apontados pelo processo de consulta para a elaboração da DEFDH, e são, acima de tudo, componentes e elementos essenciais para o estabelecimento de uma cultura dos direitos humanos.

"It is particularly important for the man or woman in the street to know his or her rights, otherwise the struggle for human dignity remain a mere slogan for the very people in dire need of protection. Indeed, after all is said and done, universal human rights must begin at home". The unforgettable Anna Eleanor Roosevelt, former First Lady of the United States of America and First President and Chair of the United Nation Commission on HR stressed this very important eloquently when, in response to the question " where do universal human rights begin? famously answered as follows: "in small places, close to home. Such are the places where everyman, woman and child seek equal justice, equal opportunity without discrimination. Unless theses rights meaning there, they have little meaning anywhere". So home, that is to say, the local level; is where we must concentrate efforts to make human rights a "living reality". 260

Papel especial ficou reservado às ONGs, conforme entendimento pacifico mesmo anterior a todo esse processo de participação que, ao seu tempo, não se eximiu de ressaltar, veemente, o papel desempenhado por este tipo de organização na $\mathrm{EDH}^{261}$, manifestações estas provenientes dos governos, INDHs e organizações internacionais, principalmente pelo seu papel de provedor de conhecimento técnico e executor de programas de EDH.

De fato, muitas ONGs desenvolvem trabalho de educação em direitos humanos

\footnotetext{
${ }^{258}$ Como observou a ONG Buraku Liberation and Human Rights Research Institute.

${ }^{259}$ MUÑOZ, 2009, p. 7.

${ }^{260}$ Do relatório da ONG Association Points-Coeur.

${ }^{261}$ A este exemplo, assevera a Soka Gakkai International: Through all experiences and surveys of the UN Decade and the first phase of the World Programme for Human Rights Education, it is crystal clear that civil society actors and NGOs are the main contributors to the promotion and implementation of human rights education. This significant role must be clearly recognised in the declaration. It is also imperative that the importance of supporting their involvement and efforts toward the implementation of human rights education and training be clearly stated in the declaration.
} 
mesmo não sendo o seu mandato específico. Por tratar de temas ligados aos direitos humanos, a função de espalhar os seus valores já cumpre uma função desmistificadora, elucidativa, informadora e, portanto, educativa. Além disso, muitas organizações internacionais, regionais ou nacionais são consideradas especialistas sobre o tema da EDH e, por esta razão, acabam por auxiliar os governos nas implantações de programas voltados para este fim, afirma a UNICEF.

Aqui observamos três tipos de ONGs: (i) as internacionais, normalmente com orçamento milionário e grande influencia entre os governos, fundações, órgãos de fomento, etc., e as cujo o escopo não se limita aos direitos humanos, mas os abarca. Ainda há as organizações de fomento - principalmente as fundações - indispensáveis para países que não detém recursos financeiros próprios para este fim; (ii) as nacionais, consideradas aqui aquelas que desempenham ações educativas de direitos humanos dentro de seus territórios, por exemplo, o Ludwig Boltzman Institute que desenvolve papel protagonista na implementação da EDH na Áustria; e (iii) as ONGs locais que desenvolvem trabalho de base, muitas vezes, de educação, dentro das comunidades, mais frequentemente encontrados em comunidades desprivilegiadas.

Isto é, no caso de um Estado não contar com uma ONG nacional solida para trabalhar o tema da EDH e não havendo o governo condições próprias para este fim $^{262}$, a assessoria das ONGs internacionais torna-se necessária ${ }^{263}$ e o envolvimento das organizações locais, idem.

A comunidade educativa é, elementarmente, outro ator importante para o desenvolvimento da EDH. Embora não seja, de forma alguma, o único, a escola é o palco central da educação. Ela e o seu entorno devem ser sensíveis aos direitos humanos dos educandos.

La discriminación social y la falta de oportunidades educativas, también se producen cuando los y las estudiantes se enfrentan con un entorno escolar

\footnotetext{
${ }^{262}$ Bons exemplos da assessoria internacional são: o projeto de educação, elaboração e introdução de módulos de formação sobre a promoção da paz e sobre a divulgação dos direitos humanos através do programa Leadership Africa, apoiado pela agência USAID e executado no Senegal e ainda, (iii) a iniciativa de EDH chamada Lift off, executada pela Anistia Internacional a pedido da Comissão de direitos humanos irlandesa.

${ }^{263}$ A este respeito comentou a ONG Lawyers Rights Watch Canada: "The Programme of Action should include a recommendation that states develop in consultation with human rights NGOs and civil society, a National Action Plan (NAP) on Human Rights Education. A state's NAP should be supported by adequate resources and articulate a schedule for the achievement of various HRE goals. Progress in achieving the $N A P$ should be monitored and evaluated periodically by a committee that includes representatives from $N G O s$ and civil society. LRWC recommends that this committee should report directly to Ministers at the provincial and federal levels with designated responsibility for implementing the NAP and HRE.
} 
insensible a sus derechos y necesidades, incluyendo una curricula que lesiona la diversidad humana y, al manipular as capacidades de aprendizaje, termina excluyendo a los grupos humanos mas vulnerables. ${ }^{264}$

Os Planos Nacionais de EDH devem ter clara a seguinte distinção: a EDH é matéria a ser inserida no currículo escolar $\left(\operatorname{art} .8^{\circ}, \S 1^{\circ}\right.$ ), como é uma metodologia em si. A proposta é fazer com que os princípios e valores da DUDH permeiem e perfaçam todo o processo educacional em sentido lato. Desta forma, os direitos humanos, seu respeito e promoção são condições indispensáveis para se construir um ambiente que permita que o ensino seja praticado e o aprendizado efetivo. Por mais obvio que possa parecer, veremos que a falta da pratica da EDH é causada por uma serie de violações de direitos humanos e resulta em mais tantas destas. Para se reverter este quadro, a escola deve ser um ambiente favorável para a EDH da mesma forma que deve ser para a educação geral. No entanto, quando a DEFDH expressa os princípios específicos da EDH que não podem escapar de qualquer ambiente, quer dizer os princípios da não-discriminação, da participação do entendimento e do respeito pelas diferenças.

The school itself must demonstrate that it takes human rights seriously. Pupils should be welcome to express their views and to participate in the running of the school as much as possible. The atmosphere in school should be characterised by mutual understanding, respect and responsibility between all actors. I have seen such schools and noticed that they tend to function much better than those run on an authoritarian model. Pupils learn social and other life skills, not only facts.

$\mathrm{O}$ artigo 10, $\S 2^{\circ}$, demonstra a importância da EDH dentro das organizações acima que desempenham papel ativo na EDH quando insta "las instituciones de la sociedad civil, al sector privado y a otros interesados pertinentes a velar por que su personal reciba educación y formación adecuadas en materia de derechos humanos."

Dentre os atores elencados na redação do artigo 10, os meios de comunicação, apesar de ganhar lugar entre os atores - novidade até o momento - não foram objeto de desdobramentos na DEFDH quanto ao seu papel, suas responsabilidades e controle. Este é um tema complicado porque frequentemente as tentativas de controle do conteúdo dos meios de comunicação de massa ensejam em censura, o que é uma violação evidente do direito de expressão e manifestação do pensamento e tema que exige cautela. $O$ papel da mídia e dos meios de comunicação será abordado, no entanto, no capitulo 4, em "Construções Sociais: a anticultura dos direitos humanos.",265

${ }^{264}$ MUÑOZ, 2009, p. 7
${ }^{265}$ Cf p. 147. 


\subsection{Definições e princípios}

As definições concluídas na $\mathrm{DEFDH}$, principalmente a definição de $\mathrm{EDH}$, foram o tema que mais interessou a todos os participantes ${ }^{266}$. A busca por um consenso na definição determinará o futuro da DEFDH, sugeriram alguns participantes. Depois de acirrado debate sobre qual definição adotar, de que maneira, e com quais elementos, a sugestão que a DEFDH reproduzisse a definição sobre a EDH trazida pela ONU através do seu programa mundial de EDH (artigos $1^{\circ}, 2^{\circ}, 3^{\circ}$ e $4^{0}{ }^{267}$ ), foi a que mais colheu apoio ${ }^{268}$.

A definição da EDH vem recebendo contribuições de diversas áreas do conhecimento, como não pode deixar ser. Os direitos humanos não são e nem jamais podem ser considerados privativos de juristas. Eles fazem parte do patrimônio mundial e devem ser entendidos e propagados por todo e qualquer individuo.

Conforme visto anteriormente, o primeiro ponto a ser discutido foi sobre considerar a EDH um direito novo ou reconhecer um direito já existente. Posicionaram-se a favor da segunda hipótese Estados-membros como o Canadá, Japão e Brasil. A proposta da Tailândia de começar a redação do artigo $1^{0}$ "everyone has the right to education which includes human rights and training" acabou por resolver a celeuma da afirmação ou reafirmação da $\mathrm{EDH}$ como direito, mas trouxe novo dilema: o direito à EDH será reconhecido como subsidiário ao direito à educação ou será um direito autônomo ${ }^{269}$ ? A

\footnotetext{
${ }^{266}$ Neste sentido comentaram os governos da Eslovênia, Angola, Finlândia, as INDH alemã, Irlandesa, Canadense, Nepalês, entre outros.

267 Relatório enviado pelo University Teacher Switzerland.: (...) au cadre conceptuelle, une définition de l'éducation et de la formation des formateurs mais aussi le rôle de l'éducation et de la formation aux droits de l'homme ; j'aimerais bien vous proposer la définition suivante, correspondante avec la définition de la "UN Decade for Human Rights Education" as "training, dissemination and information efforts aimed at the building of a universal culture of human rights through the imparting of knowledge and skills and the molding of attitudes and directed to: (a) the strengthening of respect for human rights and fundamental freedoms; (b) the full development of the human personality and the sense of its dignity; (c) the promotion of understanding, tolerance, gender equality and friendship among all nations, indigenous peoples and racial, national, ethnic, religious and linguistic groups. (d) the enabling of all persons to participate effectively in a free society; (e) the furtherance of the activities of the United Nations for the maintenance of peace", mais plus captivante et plus "quotable " (un aspect qu'il était souligné de M. Dheerujlall Seetulsingh pendant la discussion du point 3 (a) de l'ordre du jour du Comité consultatif).

${ }^{268}$ It is recommended that the draft Declaration would also benefit from a clear definition of human rights education and training. In this regard, reference could be made to the Plan of Action of the first phase of the World Programme for Human Rights Education (WPHRE), with particular focus on the: (i) definition of human rights education and training contained in paragraph 3; and (ii) human rights education and training principles within paragraph 8. Do comentário da ONU ao anteprojeto de DEFDH.

${ }^{269}$ Neste sentido: The relationship between the right to education and human rights education and training in the context whether human education is merely a part of the right to education to be described that the right to education includes human rights education. (deepening the understand on this would help the entire discussion, I think.).
} 
maioria dos participantes neste processo entende que a EDH was beyond the scope of the right to education rather than merely being part of the right to education and that human rights education and training related to all human rights so that the language must be formulated accordingly in the declaration. ${ }^{270}$

Uma definição para a EDH não é novidade neste campo de estudo. Nas ultimas duas décadas, diversos estudos sobre o tema desenvolveram definições complexas e bem esclarecedoras. A este exemplo:

\begin{abstract}
A Educação em Direitos Humanos parte de três pontos essenciais: primeiro, é uma educação de natureza permanente, continuada e global. Segundo, é uma educação necessariamente voltada para a mudança, e terceiro, é uma inculcação de valores, para atingir corações e mentes e não apenas instrução, meramente transmissora de conhecimentos. Acrescente-se, ainda, e não menos importante, que ou esta educação é compartilhada por aqueles que estão envolvidos no processo educacional - os educadores e os educandos - ou ela não será educação e muito menos educação em direitos humanos. Tais pontos são premissas: a educação continuada, a educação para a mudança e a educação compreensiva, no sentido de ser compartilhada e de atingir tanto a razão quanto a emoção. ${ }^{271}$
\end{abstract}

No entanto, a definição trazida pela DEFDH será aquela normalmente utilizada como argumento por ser a definição trazida no documento oficial e, sobretudo, por ser ela uma construção coletiva. O processo de elaboração da DEFDH não trouxe nenhuma uma inovação radical, tratando-se mais de uma ratificação de toda a produção intelectual sobre a EDH que vem sendo desenvolvida desde 1948.

A necessidade de uma conceptualização comum dos direitos humanos já estava presente na própria DUDH que considera que "uma concepção comum destes direitos e liberdades é da mais alta importância para dar plena satisfação a tal compromisso" e sobretudo, quando afirma que

o desconhecimento e o desprezo dos direitos do homem conduziram a atos de barbárie que revoltam a consciência da Humanidade e que o advento de um mundo em que os seres humanos sejam livres de falar e de crer, libertos do terror e da miséria, foi proclamado como a mais alta inspiração do homem.

Portanto, uma definição em conjunto e cristalina era a missão maior dos redatores da DEFDH. Alguém poderia sugerir que a definição de EDH é educar sobre os direitos humanos, seus princípios, valores e leis, e basta. Certamente, a definição resolve, porém, a

\footnotetext{
${ }^{270}$ FUJI, Kazunari. Em mensagem enviada ao grupo de discussão Global HRE List mantida por HREA, Disponível em http://www.hrea.org/lists2/list_messages.php?id=29. Acessado em 07.01.2012.

${ }^{271}$ BENEVIDES, 2009, p. 323.
} 
dificuldade está nos valores associados a $\mathrm{EDH}^{272}$ e na própria perenidade dos seus princípios.

Segundo a INDH irlandesa, não poderia faltar clareza conceitual sobre o exato significado de EDH e a Declaração deve ser tão substantiva e argumentativa quanto possível. Como ela não pode trazer exemplos de boas práticas, ela deve ir além de ser meramente declaratória para ter utilidade prática em avançar em processo políticos. Por este motivo, a ligação da EDH com o empoderamento, a democracia, a responsabilidade cidadã, devem estar estabelecidas tanto quanto possível, acrescentou a German Commission for Unesco.

Além de clareza, para a ONG CIFEDHOP a definição de EDH deve abraçar os direitos humanos através da educação e direitos na educação, ou seja, que a educação deve ser executada através do respeito aos direitos humanos. A EDH deve também estar conectada com a noção de uma educação de qualidade, sendo que para a educação ser considerada como tal, não pode prescindir da $\mathrm{EDH}^{273}$.

Algumas dúvidas surgiram sobre a EDH ser uma matéria ou fazer parte do currículo transversal dentro da educação para a cidadania, por exemplo, o governo da Argélia, com o que discorda o governo belga, afirmando que não há duvidas que a educação não é uma matéria, mas faz parte do currículo transversal dentro da educação para a cidadania, que é a posição majoritária nos relatórios.

Sobre o ensinar valores e princípios e direitos, o risco é ter uma educação condizente com os mesmos valores e princípios que podem ter origem em outras fontes, como a religião, a filosofia, etc., que não os valores construídos dos direitos humanos. Isto é fundamental para a universalidade e para estreitar o entendimento de individuo sobre ele e sobre os outros indivíduos de todas as nacionalidades.

É possível educar, ou seja, transmitir a outro os princípios, sem que se toque no tema dos direitos. É possível ensinar os valores, sem mencionar os princípios e, de igual sorte, ensinar os direitos sem transmitir nenhum valor ou seguir nenhum principio. Atualmente entende-se que o seu ideal é a combinação perfeita do ensinar valores, princípios e direitos,

\footnotetext{
${ }^{272}$ TIBITTS, 2007, p. 6: Values associated with HRE include: accepting differences, respecting the rights of others (especially members of less powerful groups), and taking responsibility for defending the rights of others (Partners in Human Rights Education, 1996; Dupont et al, 1999; Matus, 1996; Mertus et al, 1998; Mihr, 2004; Bernath et al, 1999; Claude 1998). Learners should be encouraged to develop empathy and multiple perspectives in order to understand human rights and the import of this value system for interpersonal behavior, such as a being considerate of others (Glover \& O'Donnel, 2003, pp. 15-17).

${ }^{273}$ comentou a German Commission for Unesco.
} 
em conjunção harmoniosa de todos os atores e elementos que a envolvem. Porém esse entendimento é atual e demorou sessenta anos para ser construído.

Sugestões mais radicais surgiram ao longo do processo. Dois relatórios - da ONG People's Movement for Human Rights Learning e do governo da Eslovênia sugeriram que o nome da Declaração fosse alterado de Declaração das Nações Unidas sobre a Educação e Formação em Direitos Humanos para Human Rights Education, Human Rights Learning and Training porque isso alinharia esta Declaração às decisões e considerações da ONU relacionadas com o tema (ex.: Ano Internacional do aprendizado dos Direitos Humanos), sob pena de trazer inconsistência ao movimento ${ }^{274}$. Na verdade, o que pretendem estas organizações é que o termo aprendizado seja adicionado aos termos educação e formação na redação do título da Declaração.

Comentaram, mesmo que brevemente, que a definição presente na Década para Educação em Direitos Humanos ${ }^{275}$ deveria ser usada como fonte inspiradora, sem se olvidar de fazer constar na definição uma conexão com o direito ao desenvolvimento e direito à vida em paz, com o que concordou a INDH irlandesa.

Segundo a INDH canadense, a DEFDH também deveria incluir: (i) educação e formação em se tornando "bons cidadãos" que demonstrem os valores de liberdade, paz, inclusão e respeito no cotidiano e no seu comportamento; (ii) educação sobre as responsabilidades que acompanham o gozo dos direitos; (iii) educação sobre como reconhecer e responder a um abuso dos direitos humanos; (iv) destacar a historia nacional e internacional dos direitos humanos com o objetivo de relembrar o passado coletivo para evitar repetir os erros e (v) educar sobre os direitos humanos e responsabilidades e, onde apropriado, em assuntos atuais de direitos humanos nacional e internacionalmente.

Por fim, entendemos pertinente o pensamento da ONG Soka Gakkai, entre outras, que propôs uma definição não exaustiva para o termo, sugerindo que a deixe aberta para mudanças que ocorrerão com o tempo.

A clear conceptualisation of human rights education needs to be provided as an international human rights standard in the declaration. The basis of the conceptualisation must be a rights-based approach of the right to human rights education and training. Currently, human rights education is interpreted as comprehending human rights training. This point also must be clarified in the declaration. If this is to be a definition, such a definition should not be

\footnotetext{
${ }^{274}$ Acrescenta a ONG em seu relatório: "As professor Betty Reardon writes and as it was quoted in the 3rd Committee: "The difference between "human rights education" and "human rights learning" is the same as between "education" and "learning"."

${ }^{275}$ Entre tantas a National Human Rights Commission Nepal.
} 
formulated as a closed or exclusive meaning of human rights education and training. As human society evolves, human rights concepts develop and new sets of rights emerge. Since human rights education comprehends all human rights and is not limited to a specific time or place, the definition should remain nonexhaustive so that as specific human rights develop conceptually and new human rights are recognised, these also are comprehended within the definition of human rights education set forth in the declaration. ${ }^{276}$

Finalmente, após muitos debates ocorridos via relatórios de participação, via manifestações no seminário de Marrakesh, bem como o discutido durante os trabalhos da Plataforma, a DEFDH traz a seguinte definição de EDH em seus artigos $1^{\circ}$ e $2^{\circ}$ :

$$
\begin{aligned}
& \text { Artículo } 1^{\circ} \text {, \& } 1^{\circ} \text {. Toda persona tiene derecho a obtener, buscar y recibir } \\
& \text { información sobre todos los derechos humanos y las libertades fundamentales y } \\
& \text { debe tener acceso a la educación y formación en materia de derechos humanos. }
\end{aligned}
$$

Como resultado dos esforços para resumir a Declaração preparada pelo Comitê, o $§ 1$ da DEFDH apresenta alguns elementos apresentados apartadamente pelo documento anterior. Assim, depreende-se da leitura do artigo $1^{\circ}$, que a EDH é um direito que envolve direitos adjacentes como o direito à informação ("obtener, buscar e recibir"), o que é reforçado no $\S 3^{\circ}$ mais claramente ao afirmar que "el disfrute efectivo de todos los derechos humanos, en particular el derecho a la educación y al acceso a la información, facilita el acceso a la educación y la formación en materia de derechos humanos."

Em seguida, declara genericamente que "la educación y la formación en materia de derechos humanos son esenciales para la promoción del respeto universal y efectivo de todos los derechos humanos y las libertades fundamentales de todas las personas", reafirmando os princípios da universalidade, indivisibilidade e interdependência dos direitos humanos, conforme $\S 2^{\circ}$, do artigo $1^{\circ}$.

A DEFDH acrescenta elementos essenciais na noção de EDH, expandindo sua definição. Ainda em seu segundo artigo afirma que a EDH contribui para a prevenção dos abusos e violações "al proporcionar a las personas conocimientos, capacidades y comprensión y desarrollar sus actitudes y comportamientos para que puedan contribuir a la creación y promoción de una cultura universal de derechos humanos", que é o proposito maior da DEFDH.

Ademais, acrescenta à definição de EDH a sugestão de definição trazida pela Anistia Internacional em seu relatório, afirmando que a EDH engloba a: (i) educação sobre os direitos humanos - "que incluye facilitar el conocimiento y la comprensión de las normas y principios de derechos humanos, los valores que los sostienen y los mecanismos que los

${ }^{276}$ Soka Gakkai International. 
protegen" 277 ; (ii) por meio dos direitos humanos - "que incluye aprender y enseñar respetando los derechos de los educadores y los educandos" 278 e (iii) para os direitos humanos - "que incluye facultar a las personas para que gocen y ejerzan sus derechos y respeten y defiendan los de los demás." 279

O processo da EDH é um processo permanente que se prolonga por toda a vida e abrange todas as idades ${ }^{280}$, característica detalhada em seguida - no $\S 2^{\circ}$ do artigo $3^{\circ}-$ somada à necessidade da EDH de envolver todos os setores, todos os níveis de ensino, levando-se em conta as liberdades acadêmicas e adequando as modalidades ao publico alvo da EDH, conforme leitura:

\begin{abstract}
La educación y la formación en materia de derechos humanos concierne a todos los sectores de la sociedad, a todos los niveles de la enseñanza, incluida la educación preescolar, primaria, secundaria y superior, teniendo en cuenta la libertad académica donde corresponda, y a todas las formas de educación, formación y aprendizaje, ya sea en el ámbito escolar, extraescolar o no escolar, tanto en el sector público como en el privado. Incluyen, entre otras cosas, la formación profesional, en particular la capacitación de formadores, maestros y funcionarios públicos, la educación continua, la educación popular, la información y la sensibilización del público en general.
\end{abstract}

Ainda sobre a definição de EDH, um elemento é de fundamental importância apesar da obviedade aparente - e, dessa forma, ganhou um artigo exclusivo. Dispõe o $\operatorname{artigo} 4^{\circ}$ :

\begin{abstract}
La educación y la formación en materia de derechos humanos deben basarse en los principios de la Declaración Universal de Derechos Humanos y los demás instrumentos y tratados pertinentes, con los siguientes propósitos: a) Fomentar el conocimiento, comprensión y aceptación de las normas y principios universales de derechos humanos (...) b) Desarrollar una cultura universal de los derechos humanos en la que todos sean conscientes de sus propios derechos $y$ de sus obligaciones respecto de los derechos de los demás (...) c) Lograr el ejercicio efectivo de todos los derechos humanos y promover la tolerancia, la no discriminación y la igualdad; d) Garantizar la igualdad de oportunidades para todos mediante el acceso a una educación y formación en materia de derechos humanos de calidad, sin ningún tipo de discriminación;
\end{abstract}

A alínea "e" deste artigo determina que a EDH baseada nos princípios da DUDH deve visar contribuir para a prevenção dos abusos e as violações de direitos humanos e combater e erradicar todas as formas de discriminação e racismo, os estereótipos e à incitação ao ódio e as atitudes preconceituosas e os preconceitos em que se baseiam.

O motivo pelo qual os redatores da Plataforma mantiveram um artigo exclusivo para este elemento da definição (contrariando a tendência por cortes no processo de concisão) é

\footnotetext{
${ }^{277} \mathrm{DEFDH}$, artigo $2^{\circ}, \S 2^{\circ}$, a).

${ }^{278}$ Idem, $\left.\S 2^{\circ}, \mathrm{b}\right)$.

${ }^{279}$ Idem $\S 2^{\circ}, \mathrm{c}$ ).

${ }^{280} \mathrm{Idem}$, artigo $3^{\circ}, \S 1^{\circ}$.
} 
a divergência que ocorre entre a EDH e outros tipos de educação semelhantes. Este dispositivo complementa a definição da EDH e surgiu como necessidade para dar clareza à definição de EDH e suas características, diferenciando-a de outras formas e processos educacionais.

Ao longo da historia da evolução dos processos educacionais, outros ramos de educação foram desenvolvidos. Esses "tipos" de educação atendem ao movimento educacional internacional e apresentam-se sob diferentes títulos, dependendo do país e da situação especifica em que se desenvolveram, tais como: educação para a paz; educação para a cidadania; educação para resolução de conflitos; educação para a sustentabilidade, educação para o dialogo, educação global, etc.

$\mathrm{O}$ que deveria ser um fenômeno natural e colaborativo para a EDH em geral, por vezes, acaba sendo um entrave. Esses movimentos educacionais acabam por concorrer com a EDH - principalmente por financiamento - mas também sobre a sua metodologia e abordagem, e desentendimentos entre as linhas são frequentes. A este respeito, comentou Margaret Sinclair ${ }^{281}$ :

I have been involved over the last decade in peace education for refugees and other conflict-affected communities (...), I helped initiate the UNHCR peace education programme now known as the INEE Peace Education Programme. From 2001-2003, I worked on emergency education at UNESCO headquarters and saw the competition between people employed there to work on human rights education and people employed for peace education. Human rights educators said that peace education was a minor and subsidiary part of their work. Peace educators, in contrast, at UNESCO and worldwide, saw human rights education as a component part of peace education. ${ }^{282}$

Ainda segundo ela, a UNESCO, através do seu International Bureau of Education (IBE), preparou um documento que deve ser entendido como um guia para o desenho, monitoramento e avaliação dos programas educacionais, chamado "Learning to live together", no qual inclui um conceito integrado de educação em EDH e educação para a paz, que cobre as habilidades cognitivas, interpessoais e suas manifestações para o tema da convivência respeitando-se as necessidades e direitos de outros.

\footnotetext{
${ }^{281}$ Margaret SINCLAIR is currently a senior consultant on humanitarian assistance. She gained her BA and D.Phil. at Oxford University. She graduated at London University in Educational Planning and Environmental Management. She hold many important positions such as Research Officer at IDS of University of Sussex. With UNESCO, Margaret SINCLAIR worked as technical adviser on the establishment of an Academy of Educational Planning and Management in Islamabad (Pakistan). She worked, as Senior Education Adviser, with UNHCR in Geneva for Emergency Education. Cf in http://www.unesco.org/education/educprog/emergency/themes/authors.htm.

${ }^{282}$ SINCLAIR, Margaret. Em mensagem enviada ao grupo de discussão Global HRE List mantida por HREA, Disponível em http://www.hrea.org/lists2/list_messages.php?id=29. Acessado em 07.01.2012.
} 
A educação para a paz, por exemplo, transmite valores que se coadunam com os do DIDH. No entanto, se não fizer referencia a eles, não pode ser considerada educação em EDH diretamente. Sem duvida, um dos objetivos da EDH - talvez o maior - é a paz. No entanto os caminhos podem ser diferentes e a paz a ser ensinada pode, inclusive, ser antagônica aos direitos humanos. Apesar de não aprovar a violência como um dos métodos de luta pelos direitos humanos, mais ainda, de luta contra a violação dos direitos humanos, o significado da não-violência pode variar desde uma ferramenta poderosa de luta de classes desfavorecidas (e o caminho a seguir), até a resiliência. Observamos algumas atividades de cultura da paz no sudeste da Ásia que mais serviam aos opressores de direitos humanos que aos educandos. De fato, misturava-se cultura de paz com preceitos religiosos como o Carma, acomodando os anseios por uma vida melhor mais condizente com os direitos humanos universais. Com isto, não estamos, de forma alguma, afirmando que todo o processo de Educação para Paz não tenha seu valor ou que seja inferior, subsidiaria, ou parte da EDH. A Educação para Paz desenvolve formidável papel aliada a EDH. O que afirmamos é que, em não havendo simetria com os princípios, valores e direitos da DUDH, qualquer modalidade de educação, mesmo tendo o mesmo fim, não pode ser considerada EDH.

Assim sendo, muitas sugestões apontavam a necessidade de estabelecer claramente parâmetros entre os tipos de educação, dessa maneira, as organizações de direitos humanos não monopolizariam outros setores.

The link with other types of education should be emphasized (inter alia so that nobody starts to fear that human rights organizations are going to "absorb" other sectors). State obligations should be outlined in an unambiguous manner. ${ }^{283}$

As discussões em torno deste tema, em verdade, ganham traços que chegam a render mais importância às criticas de David Lempert. Por exemplo:

I worry that because human rights educators can cite chapter and verse to claim legitimacy from human rights instruments they have an 'unfair' advantage over advocates of education for peace/life skills/citizenship, who are often less familiar with these instruments!!!

Ora, a declaração acima demonstra claramente o ambiente entre as diferentes correntes educacionais. Em nosso entender, os argumentos não podem prosperar. Sinclair afirma temer que os educadores de direitos humanos são capazes de citar os instrumentos internacionais ganhando vantagem sobre a educação para paz. Vantagens somente na

\footnotetext{
${ }^{283}$ Relatório enviado pela ONG belga Vormen (Expertisecentrum mensenrechten- en kinderrechteneducatie Vlaanderen).
} 
disputa por financiamento, por certo. Concluindo, sugere que o titulo da DEFDH seja alterado: I would advocate that the title of the new Declaration includes the right to education for human rights/peace/active citizenship/life skills rather than just human rights, o que, claramente, não foi acolhido pelos redatores.

A educação para a paz, como sugere seu nome, objetiva o desenvolvimento de habilidades para o comportamento pacifico o que, de certa maneira, pode ser contrario a luta pelos direitos humanos. A questão da não-violência pode ser muito relativa. Colocar milhões de pessoas na rua protestando contra politicas coloniais na Índia, apesar de maior exemplo de manifestação não-violenta, não deixa de ter sua violência, o mesmo valendo para o ocorrido em El Alto, Bolívia, em 2003 com as manifestações contra a privatização da água.

De todas as formas, lamentamos este tipo de conflito. Em nosso ver, não há hierarquia de valores entre estes tipos de educação por mais que queiram fazer crer muitos defensores de uma corrente ou de outra. Entendemos que a EDH se encerra na transmissão dos valores, princípios e direitos contidos no DIDH. Isso a determina. E é essa é a razão da DEFDH. Caso o processo educacional ensine, condizentemente, os valores, princípios e direitos contidos no DIDH, tendo eles como base, fazendo referencia a eles e, mais ainda, a partir deles, qualquer nome, metodologia ou abordagem, pode ser dada, que será, de qualquer maneira, EDH.

A EDH tem o proposito de reação. Os educandos são convocados a agir, uma vez adquiridos os conhecimentos sobre os direitos humanos. É dizer que com o aprendizado dos direitos humanos, o educando é empoderado com esse conhecimento. O empoderamento passa por três fases: (i) promoção da cultura dos direitos humanos através do desenvolvimento de valores, crenças e atitudes inerentes a ela; (ii) provisão do conhecimento e informação sobre os direitos e os mecanismos para sua proteção e (iii) encorajamento à toma de ação para defender os direitos humanos dos abusos cometidos contra eles. $^{284}$

É para por fim a esta discussão, a DEFDH determina, em seu artigo $4^{\circ}$ : “ $L a$ educación y la formación en materia de derechos humanos deben basarse en los principios de la Declaración Universal de Derechos Humanos y los demás instrumentos y tratados pertinentes (...)”. ${ }^{284} \mathrm{Cf}$ in Report of the UN Secretary General: United Nations Guidelines for national plans of action for
human rights education, UN Doc. A/52/496/Add.1, 20 October 1997. 
O empoderamento também recebeu atenção especial durante o processo de elaboração da DEFDH, entretanto, perdeu espaço com a nova redação, contrariando diversas sugestões ${ }^{285}$, inclusive para atrela-lo a outros elementos conexos como o desenvolvimento local. ${ }^{286}$

O empoderamento é estrangeirismo oriundo do termo inglês empowerment que significa capacitar, permitir, habilitar. Mais elucidativo é o termo empowering que significa "algo que faz você mais seguro e que faz você sentir que está em controle de sua vida. ${ }^{" 287}$ Este importante elemento vale para a EDH em qualquer publico alvo - seu efeito é notado nas crianças que passam por este tipo de educação em contraste com aquelas que não a tiveram, porém o empoderamento ganha roupagem especial quando tratamos de educação de adultos desprivilegiados e a aquisição de conhecimento sobre seus direitos.

\begin{abstract}
Graças aos direitos, os desiguais conquistam a igualdade, entrando no espaço politico para reivindicar a participação nos direitos existentes e sobretudo para criar novos direitos. Estes são novos não simplesmente porque não existiam anteriormente, mas porque são diferentes daqueles que existem, uma vez que fazem surgir, como cidadãos, novos sujeitos políticos que os afirmaram ser reconhecidos por a toda a sociedade. ${ }^{288}$
\end{abstract}

Quando tratamos de EDH, é consensual o entendimento que ela deve permear todos os níveis, colocando todos os indivíduos como seu publico alvo. Quando tratamos de EDH nas escolas, ou seja, tendo como publico alvo as crianças, estamos falando mais de conscientização dos direitos humanos que, apesar de levar naturalmente ao empoderamento, esse elemento se apresenta mais frequentemente na agenda da educação de adultos, em especial, aqueles desprivilegiados pelo sistema social vigente, e é aqui que a Educação popular é necessária. Desse modo, ela aparece prevista no artigo $3^{\circ}, \S 2^{\circ}$ da DEFDH, dentro de modalidades da educação.

A educação popular antes tinha como intuito educar as classes menos instruídas em seus fazeres técnicos. Nos tempos atuais, ela aparece como ferramenta democrática de

\footnotetext{
${ }^{285} \mathrm{O}$ departamento de EDH da ONG austríaca Ludwig Boltzmann Institute of Human Rights, sediada em Viena, sugere que (i) a Declaração enfatize o fato de o direito a EDH é instrumento de empoderamento que leva ao conhecimento/reconhecimento de direitos e a capacidade de reinvidica-los; compactua com esta opinião a Anistia Internacional

${ }^{286}$ Irish Human Rights Commission: Community development is an approach underpinned by human rights values, and a current challenge is build on pilot work to explicitly utilise human rights instruments and a HRBA in Community Development in a manner which compliments and reinforces the work of community groups in addressing their issues.

287 Dicionário Cambridge online. Disponivel em http://dictionary.cambridge.org/: (...) something that is empowering makes you more confident and makes you feel you are in control of your life(...)",

${ }^{288}$ CHAUÍ, Marilena. Cultura e democracia. in: Crítica y emancipación: Revista latinoamericana de Ciencias Sociales. Año 1, no. 1 (jun. 2008). Buenos Aires : CLACSO, 2008, p. 68. Disponível em http://bibliotecavirtual.clacso.org.ar/ar/libros/secret/CyE/cye3S2a.pdf. Acessado em 07.01.2011
} 
educação e modalidade cujo objetivo maior é a conscientização dos indivíduos sobre seu papel na sociedade e o empoderamento orientado para a mudança de cenários injustos, baseada na identificação dos agentes responsáveis pelos determinados direitos e as ferramentas de reinvindicação deste cumprimento. A educação popular deve atender aos interesses da classe menos favorecida e surge em contraposição a educação das classes dominantes, fundamental para transformar o atual estado das coisas.

\subsection{Estratégias para implementação}

Segundo a DEFDH, para a implementação da EDH em âmbito nacional, uma estratégia clara, bem formulada e realista é imprescindível para que esta educação seja efetiva, seguindo o Programa Mundial para Educação em Direitos Humanos que determina a necessidade de um plano de ação em nível nacional. Uma vez conhecidos os atores envolvidos e tendo uma definição em comum do que é a EDH, diversos componentes devem constar dessa estratégia para que o programa atinja os resultados esperados, seguindo o Programa Mundial de EDH, como dispõe o artigo $8^{\circ}, \S 1^{\circ}$.

Tal estratégia para a implementação da EDH passa por (i) um plano de ação bem definido, inspirado em boas práticas e objetivando estândares realísticos ${ }^{289}$ de qualidade em nível nacional e que desenvolva a EDH em um processo que se prolonga toda la vida y afecta a todas las edades ${ }^{290}$.

Para lograr bons resultados, uma reforma legislativa é necessária - na maioria dos casos - para a realização de um plano de ação bem definido, evitando-se assim, mudanças de políticas educacionais conforme e rodízio dos governantes.

Outro elemento que não pôde deixar de constar na DEFDH, de acordo com a maioria dos relatórios de respostas, é a necessidade de avaliação e monitoramento das ações tomadas. Neste sentido, sugere a ONG Soka Gakkai International:

To the maximum degree feasible, the declaration should provide for monitoring to ensure implementation by the duty-bearers and the rights-holders. Although there have been a number of commitments expressed by governments to human rights education as well as plans of action for human rights education, the lack of an effective monitoring system has been a major cause of difficulty in evaluating the implementation of human rights education. ${ }^{291}$

\footnotetext{
${ }^{289}$ Talvez o conteúdo do relatório do Estado colombiano a este respeito seja pouco realista, senão vejamos: $\mathrm{O}$ desafio do governo de Bogotá é implementar o PLANEDH Plano Nacional de Educação em Direitos Humanos em níveis departamentais e municipais. Um plano consistente que formará 70.000 alunos.

${ }^{290} \mathrm{DEFDH}$, artigo $3^{\circ}, \S 1^{\circ}$.

${ }^{291}$ Relatório da Soka Gakkai International.
} 
Em termos da responsabilidade do Estado e a necessidade de uma estratégia, um bom resumo conclusivo de todo o comentado na fase de coleta de informações é a definição trazida pela ONG Canadense Lawyers Rights Watch:

The Programme of Action should include a recommendation that states develop in consultation with human rights NGOs and civil society, a National Action Plan (NAP) on Human Rights Education. A state's NAP should be supported by adequate resources and articulate a schedule for the achievement of various HRE goals. Progress in achieving the NAP should be monitored and evaluated periodically by a committee that includes representatives from NGOs and civil society. LRWC recommends that this committee should report directly to Ministers at the provincial and federal levels with designated responsibility for implementing the NAP and HRE. ${ }^{292}$

Outra característica inescapável que Comitê Consultivo deveria buscar, segundo algumas sugestões era a obrigatoriedade da EDH em todos os níveis o que, não pode ser acolhido pelos redatores. Não basta promover a EDH em todos os níveis ou como matéria transversal, como princípio da educação ou mesmo como matéria específica, se essa não for conteúdo obrigatório, apontou a INDH croata: "human rights education was introduced in the Primary School Curricula and Teaching Programme, but only as an optional integrative content ${ }^{, 293}$. A obrigatoriedade contrariaria a intenção de buscar consenso sobre os elementos a constar da DEFDH.

Idealisticamente, um Plano Nacional de EDH, deve conter os seguintes elementos: (i) avaliação constante; (ii) seguimento das ações; (iii) a participação de $\operatorname{todos}^{294}$; (iv) a adequação da modalidade de educação ao publico alvo; (v) a atenção aos grupos vulneráveis, (vi) atenção às diferentes condições sócio-financeiras; (vii) o uso da tecnologia da informação (viii) as manifestações artísticas.

As modalidades de EDH - previstas no artigo $3^{\circ}, \S 2^{\circ}-$ são:

La educación y la formación en materia de derechos humanos concierne a todos los sectores de la sociedad, a todos los niveles de la enseñanza, incluida la educación preescolar, primaria, secundaria y superior, teniendo en cuenta la libertad académica donde corresponda, y a todas las formas de educación, formación y aprendizaje, ya sea en el ámbito escolar, extraescolar o no escolar, tanto en el sector público como en el privado. Incluyen, entre otras cosas, la formación profesional, en particular la capacitación de formadores, maestros y funcionarios públicos, la educación continua, la educación popular, la información y la sensibilización del público en general. (grifos nossos).

A diversidade de modalidades de EDH é apontada como um ponto forte porque

\footnotetext{
${ }^{292}$ Relatório da ONG Lawyers Rights Watch Canada. (grifo nosso).

${ }^{293}$ Relatório da Croatia Ombudsmann.

${ }^{294}$ Estes três primeiros elementos estão previstos no artigo $8^{\circ}, \S 2^{\circ}:$ En la concepción, aplicación, evaluación y seguimiento de las estrategias, los planes de acción, las politicas y los programas deben participar de todos los interesados pertinentes, entre otros el sector privado, la sociedad civil y las instituciones nacionales de derechos humanos, alentando, según corresponda, las iniciativas de múltiples interesados.
} 
permite a localização dos princípios dos direitos humanos de diversas maneiras. Os valores universais necessitam ser particularizados not only in terms of content but also purpose, goals and implementation. We need to carry out a similar process in the sharing of evaluation tools and processes ${ }^{295}$.

Além disto, as diferentes modalidades de EDH são necessárias para adequa-la ao publico alvo, condição essencial para um bom plano nacional de EDH, com o que concordaram predominantemente os relatórios ${ }^{296}$ e como, ao final, dispôs a redação do artigo $3^{\circ}, \S 3^{\circ}$ :

La educación y la formación en materia de derechos humanos deben emplear lenguajes y métodos adaptados a los grupos a que van dirigidas, teniendo en cuenta sus necesidades y condiciones especificas.

As divergências sugiram quando o grupo alvo da EDH é também um grupo vulnerável. Senão, vejamos: $\mathrm{O}$ artigo $5^{\circ}, \S 2^{\circ}$ declara que

La educación y la formación en materia de derechos humanos deben ser accesibles y asequibles para todos, y deben tener en cuenta los retos, los obstáculos, las necesidades y las expectativas particulares de las personas y los grupos en situaciones vulnerables y desfavorables, en especial las personas con discapacidad, a fin de fomentar el empoderamiento y el desarrollo humano, contribuir a la eliminación de las causas de exclusión o marginación y permitir a todos el ejercicio de todos sus derechos.

Notamos três elementos condensados neste paragrafo: (i) a atenção ao grupo em situação de vulnerabilidade e desfavorabilidade - em especial às pessoas com deficiência; (ii) o multiculturalismo e (iii) a atenção as diferentes situações econômicas.

Muito se discutiu sobre quais grupos constariam dentre os chamados grupos vulneráveis. Sugestões indicavam a inclusão de um extenso rol, listando os jovens, os migrantes, os refugiados, os estrangeiros, os analfabetos, as pessoas pertencentes às minorias étnicas, sociais, dentre outros tantos. Sem embargo, os redatores optaram por um texto mais genérico. Em especial, houve forte pressão para que se incluísse os povos indígenas e as pessoas com deficiência, seguindo o costume de reafirmar direitos recentemente positivados ${ }^{297}$. Como notado, apenas as pessoas com deficiência foram

\footnotetext{
295 TIBITTIS, 2007, p. 3.

${ }^{296}$ Istituto Internazionale Maria Ausiliatrice (IIMA), por exemplo.

${ }^{297}$ UNFPA (United Nations Population Fund) It is important to include persons with disabilities and indigenous peoples as per the last two respective international instruments; we also suggest including a gender approach and an inter-cultural perspective that takes into account cultural particularities and diversities: This approach can facilitate the implementation of the right to human rights education and training based on a thorough understanding of the values and belief systems as well as social practices governing norms and can help to identify positive values and practices that would facilitate and more effectively promote locally the right to human rights education and training. Cultural knowledge, awareness and engagement of local communities are vital to aid effectiveness and to sustainability of change
} 
incluídas no texto o que, além de não atender às recomendações para inclusão dos povos indígenas $^{298}$, contraria, sobretudo, a pertinente observação da ONG The International Disability Alliance que sugeriu que o termo "deficiência" fosse retirado da lista de razões da vulnerabilidade por esse entendimento contrariar o artigo $3^{\circ}$ da Convenção sobre os Direitos das Pessoas com Deficiência ${ }^{299}$, que entende ser a deficiência característica da diversidade humana (mesma idéia defendida pela Anistia Internacional). Porém, por um lado, caso restasse de fora, certamente muitos ativistas dos direitos das pessoas com deficiência ficariam desapontados dados os problemas enfrentados pelas pessoas com deficiência em nossa sociedade, inclusive na educação.

Para se identificar o grupo alvo da EDH (vulnerável ou não), pretendendo buscar a melhor modalidade de EDH a ser utilizada, a UNICEF acrescentou: (i) o caso da EDH ser implantada em situações de emergência e situações de crise pós-conflito; (ii) que se deve levar em consideração a exclusão social ${ }^{300}$ como definidora de um grupo alvo específico e (iii) que deve endereçar a EDH para populações rurais e crianças fora da escola (dropped out of school).

Dentre as categorias sugeridas para constar como grupos vulneráveis, os refugiados, migrantes e minorias étnicas acabaram por constar nos $\S \S 3^{\circ}$ e $4^{\circ}$ do artigo $5^{\circ}$. Este, seguindo a determinação dos grupos vulneráveis, determinam a EDH deve tener en cuenta las diferentes situaciones económicas, sociales y culturales, favoreciendo las iniciativas locales a fin de fomentar la aceptación del objetivo común que es la realización de todos los derechos humanos para todos". Aquele, por sua vez, esclarece que deve abarcar, enriquecer e inspirarse en la diversidad de las civilizaciones, religiones, culturas y tradiciones de los diferentes países, reflejada en la universalidad de los derechos humanos.

\footnotetext{
${ }^{298}$ Secretariat of the UN Permanent Forum on Indigenous Issues. Entre os elementos de atenção ao grupo alvo, atenção aos grupos vulneráveis e multiculturalismo, a Declaração deve levar em consideração a situação dos povos indígenas que têm sido historicamente marginalizados e excluídos. A EDH é um elemento crucial para a atenção pública e empoderamento destes indivíduos.

${ }^{299}$ Convenção sobre os Direitos das Pessoas com Deficiência, Artigo $3^{\text {o }}$ : Os princípios da presente Convenção são: (..) d) $\mathrm{O}$ respeito pela diferença e pela aceitação das pessoas com deficiência como parte da diversidade humana e da humanidade. Disponível em http://www.planalto.gov.br/ccivil_03/_Ato20072010/2009/Decreto/D6949.htm. Acessado em 08.10.2011.

${ }^{300} \mathrm{~A}$ este respeito concorda a ONG FIMARC (Fédération Internationale des Mouvements d'Adultes Ruraux Catholiques): Dans la situation actuelle du monde, crises économiques, financières, alimentaires, énergétiques...il nous apparaît qu'il y a de grands risques pour que des violations de droit de l'homme soient encore plus fréquentes. Les victimes en sont les plus pauvres et les plus démunis. Dans ce contexte il nous semble particulièrement important de redire toute l'importance de la formation aux droits de l'homme. Il existe pas mal d'instruments, souvent méconnus pour leur défense.
} 
Do descrito acima, concluímos que a vulnerabilidade das pessoas em situações econômicas e sociais restaram prejudicadas devida a importância da EDH como ferramenta de desenvolvimento económico-social. Outrossim, que as recomendações dos $\S \S 3^{\circ}$ e $4^{\circ}$ valem em especial para as ONGs internacionais em seu trabalho de assessoria e desenvolvimento dos planos de EDH nacionais, que devem, obrigatoriamente, atender ao respeito à diversidade cultural.

Caminhando ao encontro entre a atenção ao grupo alvo e o multiculturalismo, vale colar a sugestão da SUHAKAM (INDH malasiana) em relação aos trabalhadores migrantes e refugiados:

\begin{abstract}
A special emphasize should be given on the right to education for children of refugees and migrant workers. The group is often neglected and marginalised due to lack of concern and policies at the national level. The problem is worst in a receiving country like Malaysia, where there are about 2 million migrant workers and large group of refugees from Myanmar especially. Furthermore, Malaysia does not recognise refugees and is not a signatory to the Convention relating to the status of Refugees to protect migrant workers and their children. Thus, this group of children do not have the opportunity to be enrolled in the formal education system or to receive any form of quality education although there are initiatives by some groups and NGOs. It is recommended that UN bodies could assist in developing suitable approaches for these underprivileged groups towards achieving education for all.
\end{abstract}

E, finalmente, a redação da DEFDH fez constar outras ferramentas a serem usadas dentro desta estratégia de implementação, como o uso das novas tecnologias da informação e os meios de comunicação ${ }^{301}$, assim como o uso das manifestações $\operatorname{artísticas~}^{302}$ como ferramentas para a EDH e como forma de superar a falta de recursos financeiros.

No projeto de DEFDH do Comitê Consultivo, os últimos artigos foram categorizados como outras propostas. Dentre elas, figurava a sugestão para a criação de um centro internacional de educação em direitos humanos para a servir como referencia na formação de profissionais neste campo bem como o uso de embaixadores da boa vontade, por entender a importância de pessoas de destaque na sociedade levarem mensagens dos direitos humanos, como já o fazem a UNICEF e o ACNUR, por exemplo.

As duas sugestões ficaram de fora da redação do texto. Os redatores defenderam que o uso de embaixadores da boa vontade não seria objeto da Declaração mas sim uma ferramenta a ser utilizada a qualquer tempo (através de uma resolução, por exemplo), bem como a fundação do centro de estudos foi julgada precoce por não se contar com fundos definidos para este empreendimento. Sem embargo, apesar de restar fora, esta discussão foi

\footnotetext{
${ }^{301}$ DEFDH, artigo $6^{\circ}, \S 1^{\circ}$.

${ }^{302}$ Ibid., $\S 2^{\circ}$.
} 
decisiva para que um novo centro de EDH fosse imediatamente criado - em atenção ao encontro do Conselho da Europa em 2005 (Warsaw Summit) e tendo como motivação final os preparativos da DEFDH - em Wergeland, na Noruega, já que este país se candidatou a financiar este projeto. No entanto, trata-se de um centro sob os auspícios do Conselho da Europa, sendo, portanto, um centro regional e não internacional.

Assim, tendo comentado sobre os atores envolvidos para a execução da EDH definida em conjunto na DEFHD e através de uma estratégia clara, passamos a analisar o que entendemos ser os maiores obstáculos para a efetivação da EDH. 


\section{Capitulo 4}

\section{Perspectivas de efetivação: o mundo como não é hoje}

A DEFDH tem o imenso desafio de colaborar para construir uma cultura dos direitos humanos, conforme dispõe seu artigo $2^{\circ}, \S 1^{0303}$ e $4^{\mathrm{o}}$, "b". 304

A cultura dos direitos humanos é fundamental para fazer valer os princípios e valores relativos a eles, sem embargo, o que vivemos em larga escala atualmente é uma cultura contraria aos direitos humanos, ou uma anticultura dos direitos humanos, cujo propósito é impedir o avanço desses ideais ao passo que garanta a manutenção de privilégios.

A DEFDH enfrenta vários obstáculos para sua implementação e mais ainda para sua efetivação. Dentre estes, o primeiro será argumento sobre a sua própria natureza; a DEFDH não contém forca vinculante, portanto, não dispõe de mecanismos legais para efetivar-se. Contudo, a afirmação que a DEFDH somente servirá para preencher os arquivos eletrônicos da legislação internacional de direitos humanos não deve prosperar. Apesar de não ser um instrumento legal, espera-se da DEFDH os mesmos efeitos surtidos por outros documentos da mesma natureza, como foram o Helsink Final Act (de 1975), a Carta de Paris, (de 1990), a Declaração sobre os Princípios Fundamentais e Direitos nos Ambiente de Trabalho (de 1998) e, especialmente, a DUDH. Esta, revolucionou o modo de pensar e influenciou todas as sociedades contemporâneas, inclusive em suas legislações nacionais, estando presente na maioria das Constituições em todo o mundo.

Além disso,

(...) é preciso não esquecer, no entanto, que o Direito vive, em última análise, na consciência humana. Não é porque certos direitos subjetivos estão desacompanhados dos instrumentos assecuratórios próprios que eles deixam de ser sentidos no meio social como exigências impostergáveis. Aliás ninguém mais nega, hoje, que a vigência dos direitos humanos independe do seu reconhecimento constitucional, ou seja, de sua consagração no direito positivo

\footnotetext{
${ }^{303} \mathrm{DEFDH}$, Artigo $2^{\circ}$, § 1. La educación y la formación en materia de derechos humanos están integradas por el conjunto de actividades educativas, de formación, información y aprendizaje que tienen por objeto promover el respeto y la observancia universales de los derechos humanos y las libertades fundamentales, contribuyendo así, entre otras cosas, a la prevención de los abusos y violaciones de los derechos humanos al proporcionar a las personas conocimientos, capacidades y comprensión y desarrollar sus actitudes y comportamientos para que puedan contribuir a la creación y promoción de una cultura universal de derechos humanos.

304 Ibid., Artigo $4^{\circ}$ : La educación y la formación en materia de derechos humanos deben basarse en los principios de la Declaración Universal de Derechos Humanos y los demás instrumentos y tratados pertinentes, con miras a: (...) b) Desarrollar una cultura universal de los derechos humanos en la que todos sean conscientes de sus propios derechos y de sus obligaciones respecto de los derechos de los demás, favoreciendo el desarrollo de la persona como miembro responsable de una sociedad libre y pacífica, pluralista e incluyente;
} 
estatal como direitos fundamentais (Grundrechte, segundo a terminologia alemã). Por isso mesmo, uma proclamação de direitos, mesmo quando despida de garantias efetivas de seu cumprimento, pode exercer, conforme o momento histórico que é lançada, o efeito de um ato esclarecedor, iluminando a consciência jurídica universal e instaurando a era da maioria histórica do homem. $^{305}$

A DEFDH não contem mecanismos jurídicos que imponham sanções aos Estadosmembros, como haviam sugerido diversos participantes da redação. Ela é um resolução aprovada pela ONU e, tecnicamente, é um recomendação desta aos Estados-membros. Como a DUDH, ela servirá mais como uma prescrição informal e uma referencia legal para instruir processos decisórios que ocorrem em âmbito nacional dos Estados-membros em relação à EDH.

Com a DEFDH, a EDH ganha importância nas agendas politicas na sociedade internacional. Como afirmamos anteriormente, ela não inova mas dá sequencia ao processo de EDH que vem ganhando corpo desde a década de noventa, principalmente.

A educação, quase que unanimemente, é apontada como único meio de desenvolvimento das sociedades atuais. A EDH, por sua vez, é apontada como mecanismo de mudança individual e coletiva, ou seja, empodera os indivíduos dando-lhes elementos para sua conscientização sobre os direitos humanos, estabelecendo, ao final da linha, uma cultura dos direitos humanos ao esclarecer direitos e deveres.

Sem embargo, esta tentativa de instauração de uma nova cultura encontra resistência em elementos das culturas já existentes e nos modos de pensar de seus indivíduos.

Este objetivo é dar continuidade ao mandato da DUDH. A ideia de espalhar os ideais dos direitos humanos nas sociedades está presente desde 1948 somente havendo campo para a adoção da uma declaração especifica sobre EDH em 2011.

Além dos obstáculos materiais de efetivação deste instrumento, o objetivo a que se propõe, (mudar os valores de uma sociedade) encontra obstáculos que estão incorporados no modo de vida e formato da cultura social cotidiana.

A seguir, iremos inter-relacionar dois elementos que entendemos serem os maiores obstáculos para a efetivação da EDH, quais sejam: (i) o principio da igualdade e as desigualdades e (ii) o multiculturalismo.

Finalmente, trataremos das (iii) Construções sociais da realidade, como meio de perpetuação destes obstáculos impostos para a implementação e final efetivação do direito humano.

${ }^{305}$ COMPARATO, 2010, p. 151. 


\subsection{O principio da igualdade e as desigualdades}

$\mathrm{Na}$ redação final da DEFDH o principio da igualdade está presente no artigo $4^{\circ}$ que determina que a EDH está baseada nos princípios da DUDH e demais instrumentos do $\mathrm{DIDH}^{306}$, onde o principio da igualdade não fica apenas implícito, mas expresso nas alíneas "c", "d" e "e":

c) Lograr el ejercicio efectivo de todos los derechos humanos y promover la tolerancia, la no discriminación y la igualdad;

d) Garantizar la igualdad de oportunidades para todos mediante el acceso a una educación y formación en materia de derechos humanos de calidad, sin ningún tipo de discriminación;

e) Contribuir a la prevención de los abusos y las violaciones de los derechos humanos y a combatir y erradicar todas las formas de discriminación y racismo, los estereotipos y la incitación al odio, y las actitudes perjudiciales y los prejuicios en que se basan. (grifos nossos)

Relembra o principio da igualdade - especificamente baseada no gênero - o artigo $5^{\circ}$, cujo $\S 1^{\circ}$ determina que as iniciativas de EDH deben basarse en los principios de igualdad, dignidad humana, inclusión y no discriminación, especialmente la igualdad entre niños y niñas y entre hombres y mujeres.

Há 63 anos, a DUDH abria com os dizeres: "Todos os seres humanos nascem livres e iguais em dignidade e em direitos. Dotados de razão e de consciência, devem agir uns para com os outros em espírito de fraternidade." ${ }^{307}$ No entanto, ao primeiro olhar é possível constatar que, de maneira alguma, somos iguais.

Igualdade é a qualidade daquilo que é igual; uniformidade. De certo, a única característica igual que os indivíduos têm é a qualidade de serem humanos, portanto, pertencentes à mesma espécie de mamíferos primatas, por ser, a própria diversidade, uma característica do ser humano. Naturalmente, somos desiguais. Cada ser humano é biologicamente único, portanto, não existe igualdade absoluta. O principio da igualdade trata de uma única característica igual entre os indivíduos que os fazem membros da sonhada família humana. Esta propositura "somos todos iguais" inaugurada nas declarações americana e francesa, conviveu pacificamente com a não observância pratica deste principio até que, "no curso da segunda metade do século XX, no entanto, tornou-se

\footnotetext{
${ }^{306} \mathrm{DEFDH}$, Artigo $4^{\circ}$ : La educación y la formación en materia de derechos humanos deben basarse en los principios de la Declaración Universal de Derechos Humanos y los demás instrumentos y tratados pertinentes, con miras a: (...).

${ }^{307}$ DUDH, artigo $1^{\circ}$.
} 
evidente, no mundo todo, que o principio da igualdade essencial dos seres humanos dever ser complementado com o reconhecimento do chamado direito à diferença." ${ }^{308}$

A partir deste momento, o principio da igualdade começa a ser mais elaborado, apesar de não alcançar, ate os dias atuais, um entendimento pacifico sobre o termo, dada sua abstratividade e contrariedade factual.

Tal contrariedade, ou negação fática, sempre existiu, uma vez que referido principio não encontrava situação favorável quando do seu surgimento, assim sendo, sempre foi, desde sua gênese, um objetivo a ser buscado. Desse modo, atender ao principio da igualdade significa diminuir as diferenças históricas que caracterizam a sociedade e respeitar as desigualdades naturais, considerando todos os indivíduos como detentores dos mesmos direitos, concretizando a ideia de que somos iguais em direitos. O problema, porém, na verdade, é estrutural e começou muito anteriormente.

A primeira desigualdade entre os seres humanos é a diferença entre o homem e a mulher e é justamente esta primeira diferença o berço de todo o problema da igualdade na atualidade.

Com a desigualdade biofísica entre homens e mulheres surge a primeira manifestação de como lidar com essa diferença. A violência da força bruta é a ferramenta que habilitou o homem a colocar-se em situação de superioridade. Como bem sabemos, essa opressão homem-mulher persiste até os diais atuais em larga escala, preenchendo os cotidianos sociais.

Desta interação, surgiu o patriarcado aproximadamente há 7.000 anos $^{309}$. Este sistema das relações sociais de poder são introjetados pelos indivíduos e replicados em seu modo de pensar, agir, ser e este mindset influencia tanto homens quanto mulheres. $\mathrm{O}$ patriarcado é o paradigma que estrutura todas as relações e instituições sociais e foi construído com base na (e graças à) naturalização da subordinação, da exploração, da exclusão e da opressão, tendo o homem como único sujeito. Na história, na visão do mundo, "o homem estabelece uma relação direta com a natureza e a cultura, situando-se como sujeito, enquanto que a mulher se posiciona com relação ao homem, sendo

\footnotetext{
${ }^{308}$ COMPARATO, Fabio Konder. Os 60 anos da Declaração e nossa Constituição, in Brasil Direitos Humanos 2008: a realidade do país aos 60 anos da declaração universal. Brasília: SEDH, 2008, p. 15.

${ }^{309}$ JOHNSON, Allan G. Dicionário de sociologia: guia prático da linguagem sociológica. Tradução Ruy Jungmann, consultoria Renato Lessa. Rio de Janeiro: Jorge Zahar Ed., 1997. p. 171.
} 
considerada como o "outro", 310 "El patriarcado no se refiere simplemente a un régimen en el que se impone el poder masculino. Se trata mas bien de un sistema de dominación que implica a todas las personas y en el que sufren hombres, mujeres, niños, niñas." 311

O patriarcado é um sistema ideológico social que permeia predominantemente as sociedades atuais, se não sua totalidade. Este sistema se resume no estabelecimento de prioridades e o reforço negativo das diferenças como justificativa para a opressão e esta baseia-se, ao final, na violência que relaciona todos membros desta sociedade.

\begin{abstract}
Las manifestaciones actuales del patriarcado se han convertido en un sistema de creencias que recogen la herencia mas antigua de dominación entre las personas. Ese sistema ideológico es un marco social o una forma de organización que define las relaciones entre las personas como relaciones entre superiores e inferiores.
\end{abstract}

Portanto, na mentalidade patriarcal o homem é mais importante que qualquer outro ente no planeta. Somente outro homem pode contrasta-lo, e, por este motivo, logo a hierarquia entre eles foi estabelecida, e a força (quer física, quer política, quer do capital), determina a desigualdade entre eles.

"El patriarcado da cuenta, entonces, de un sistema basado en la opresión y la desigualdad" ${ }^{, 312}$ com o qual concordam tacitamente todos os membros da sociedade que defendem o status quo por interesse ou por simplesmente não estarem conscientes deste mecanismo.

Este sistema social - onde figura o pai como centro do poder - é transmitido de uma geração à outra através dos símbolos de riqueza prestigio e poder que a representam, que, inexoravelmente, estão presentes na educação.

Com o passar do tempo, o poder centralizador concentrado na figura do pai, perde força, principalmente devido ao surgimento das grandes sociedades autônomas industriais no mundo econômico em substituição às velhas empresas familiares. Este processo desconcentrou o poder na figura do pai, transferindo-o para a esfera politica. Ao final, o mecanismo continua, com a única diferença de não ser o seio da família o maior meio para a propagação do sistema social do patriarcado, embora a família e as tradições sempre são elementos presentes nesta cultura e os responsáveis pela nossa introdução neste sistema.

A diluição deste pensamento nas sociedades atuais é catastrófica. Os valores transmitidos como referencia a ser buscada pelas crianças é o poder, o prestigio e a riqueza

${ }^{310}$ BOBBIO, N.; MATTEUCCI, N.; PASQUINO, G.. Dicionário de politica I. Trad., Carmen C. Varriale et ai. Coord. Trad. Joao Ferreira e Luis Guerreiro Pinto Cacais. 11 ${ }^{\text {a }}$ Ed. Brasília: UNB, 1998. p. 489.

${ }^{311}$ MUÑOZ, 2009. p. 9.

312 Opus citatum. 
material. O poder é paralelo e resultado dos outros dois. O prestigio envolve os jogos de influência, a bajulação, o corporativismo, etc., e é ferramenta para se ter poder, enquanto riqueza, principalmente na sociedade do consumo, é o grande objetivo da existência humana.

Estes valores culturais levam, inevitavelmente, às violações de direitos humanos.

La vulneración de los derechos humanos es, en gran medida, consecuencia del sistema patriarcal vigente que promueve la jerarquí, la desigualdad, la dominación de unos sobre otros, las múltiples formas de discriminación, la violencia y también el mito que este tremendo 'status quo' es permanente, estático, al cual todas y todos nos tenemos que ajustar. ${ }^{313}$

Como observamos ao longo desta dissertação, ao comentarmos sobre as relações sociais existentes nas sociedades que variaram em diferentes modos de acordo com a localização e tempo de ocorrência, vimos que o mundo sempre foi dividido em classes sociais, castas, estamentos, etc., enfim: os que tem e os que não tem, ou, seguindo a lógica do sistema patriarcal, superiores e inferiores, opressores e oprimidos. Por sermos separados em classes sociais logo do nascimento, criamos uma segunda desigualdade, a oriunda do processo de socialização dos indivíduos em uma mesma sociedade, ou seja, a desigualdade social sob o regime patriarcal.

\begin{abstract}
Nela as diferenças e assimetrias sociais e pessoais são imediatamente transformadas em desigualdades, e estas, em relação de hierarquia, mando e obediência. Os indivíduos se distribuem imediatamente em superiores e inferiores, ainda que alguém superior numa relação possa tornar-se inferior em outras. Todas as relações tomam forma de dependência, da tutela, da concessão e do favor. Isso significa que as pessoas não são vistas, de um lado, como sujeitos autônomos e desiguais, e, de outro, como cidadãs e, portanto, como portadoras de direitos. É exatamente isso que faz a violência ser a regra da vida social e cultural. ${ }^{314}$
\end{abstract}

Durante o processo de elaboração da redação da DEFDH, o princípio da igualdade teve ampla atenção. O tema das desigualdades é um obstáculo estrutural para a satisfação da EDH e frequentemente a não-discriminação com base no gênero é mais advogada que outros tipos de discriminação, justamente por ser ela a base de todas as outras.

Conforme podemos notar, a DEFDH fala de não-discriminação com base no gênero e não-discriminação de qualquer natureza. Dessa maneira, é dada mais atenção à discriminação com base no gênero que à discriminação racial, por exemplo. Por mais compreensível que possa soar, a ausência do racismo e outros tipos de discriminação certamente incomoda.

\footnotetext{
${ }^{313}$ MUÑOZ, 2009, p. 2.

${ }^{314}$ CHAUÍ, 2008, p. 70.
} 
O racismo e o combate a ele, além de uma das razões materiais para a DEFDH como vimos anteriormente - é um dos maiores exemplos de desigualdade construída fazendo parte do diálogo internacional pelo menos desde a tentativa da Liga das Nações, donde destacamos o discurso de Haile Selassie, líder da Etiópia, proferido neste extinto órgão em 1936:

\begin{abstract}
"Enquanto a filosofia que declara uma raça superior e outra inferior não for finalmente e permanentemente desacreditada e abandonada; enquanto não deixarem de existir cidadãos de primeira e segunda categoria de qualquer nação; enquanto a cor da pele de uma pessoa for mais importante que a cor dos seus olhos; enquanto não forem garantidos a todos por igual os direitos humanos básicos, sem olhar a raças, até esse dia, os sonhos de paz duradoura, cidadania mundial e governo de uma moral internacional irão continuar a ser uma ilusão fugaz, a ser perseguida mas nunca alcançada. E igualmente, enquanto os regimes infelizes e ignóbeis que suprimem os nossos irmãos, em condições subumanas, em Angola, Moçambique e na África do Sul não forem superados e destruídos, enquanto o fanatismo, os preconceitos, a malícia e os interesses desumanos não forem substituídos pela compreensão, tolerância e boa-vontade, enquanto todos os Africanos não se levantarem e falarem como seres livres, iguais aos olhos de todos os homens como são no Céu, até esse dia, o continente Africano não conhecerá a Paz. Nós, Africanos, iremos lutar, se necessário, e sabemos que iremos vencer, pois somos confiantes na vitória do bem sobre o mal."
\end{abstract}

Dessa forma, causa estranheza e desconforto que o tema racial não tenha sido incluído na letra da DEFDH explicitamente. É certo que o legislador deve optar ou por um texto especifico ou genérico. No caso, ao elencar um tipo de discriminação em detrimento as outras que estariam cobertas pelo "de qualquer natureza", a redação acaba por ser hibrida. Assim sendo, muitos objetos de discriminação restaram somente implícitos na DEFDH tais como idade, deficiência física ${ }^{315}$, cor da pela, situação laboral, crença étnica, opinião pública, situação familiar, orientação sexual ${ }^{316}$. Esta última sempre omitida dos documentos internacionais em que pese quão frequente ela esta nas sociedades atuais, na educação, por exemplo.

É entendido que o texto de um documento deva ter a maior clareza possível e listar expressamente o seu objeto. Entendemos, no entanto, que o legislador não pode ficar no meio do caminho, sendo que deve escolher ou elencar todos os detalhes, no caso os motivos para a discriminação (tarefa nem sempre possível) ou optar por um texto mais genérico.

A ONG HREA havia sugerido que o Comitê Consultivo optasse por esgotar todos os motivos de discriminação, incluindo-se nacionalidade, propriedade, nascimento, opinião política ou outra, e ainda assim, para que conclua o parágrafo de maneira não terminativa,

\footnotetext{
${ }^{315}$ Como sugere a ONG The International Disability Alliance.

${ }^{316}$ Como sugere, entre outros, o Ludwig Boltzmann Institute of Human Rights.
} 
adicionando ao final da lista o termo "ou de qualquer outra natureza análoga. ${ }^{317}$

Um comentário que nos chamou a atenção foi da Anistia Internacional sobre o foco que deve ser escolhido para tratar do tema. Em seu parecer, não se deve adotar a estratégia de promover o principio da igualdade através do acesso igualitário, mas sim promover o principio da não-discriminação, com o que concordamos plenamente, por ser esta mais clara, trazendo na sua própria definição, seu mandamento expresso ("não-discriminar"). Este pensamento representa justamente a natureza corretiva do principio da igualdade, ele não vem para ser uma atitude negativa, mas uma ação ativa para consertar o arranjo social, em que a desigualdade ou é construída para atender interesses, ou ignorada por não interessar, ou ainda, desrespeitadas para justificar a exploração.

O principio da igualdade atrela-se ainda com outros princípios. Em relação a liberdade, a igualdade é entendida uma vez que todos os indivíduos são considerados livres. Livres para manifestarem-se e livres para empreender. A divisão da riqueza e o acesso a ela é falaciosamente defendida como uma condição de igualdade e a meritocracia colabora neste processo de aceitação do sistema vigente.

Já com relação à dignidade, muitas vezes escutamos discursos que a consideram como o limite da expansão da desigualdade, principalmente a social. Podemos ser desiguais (socialmente) mas desde que a dignidade seja garantida para todos. O problema deste discurso é a abstratividade da concepção de dignidade. O termo além de perene, depende da concepção que cada um tem de mundo. O que parece indigno para uns pode ser o desejo de outros. De todas as formas, a desigualdade social, geradora da pobreza extrema atingiu um estagio em que o conceito de dignidade aparece mais cristalino. Com isso afirmamos que a indignidade decorrente da miséria a que muitos são condenados é muito mais facilmente notada e muito mais concreta que seu antônimo.

Concordamos com a discussão proposta por Fábio Comparato e Maria Victoria Benevides que, em artigo recente, buscam esclarecer as raízes da questão, apontando o respeito à dignidade de todo ser humano como a razão principal para o caráter universal dos direitos humanos. De que falam quando recorrem à dignidade da pessoa humana para situar a legitimidade dos Direitos Humanos?

"Hoje, todos os textos internacionais elucidam a dignidade como fruto da própria "humanização"; vale dizer, foi o ser humano que criou ele mesmo o Direito. Ele mesmo

\footnotetext{
${ }^{317}$ Para o inglês all other analogous grounds.
} 
desenvolveu a idéia de dignidade em grandes textos normativos. A dignidade pode ser entendida por critério de racionalidade, mas isso não basta. Quando se trata de valores éticos (intrínsecos aos Direitos Humanos), tem-se um processo educativo no qual se procura atingir a razão, mas também a emoção, "os corações e as mentes". Pois o bicho humano não é apenas um ser que pensa e raciocina, mas que chora e que ri, capaz de amar e de odiar, capaz de indignação e enternecimento, capaz da criação estética. O filósofo Unamuno alertava: o que mais nos diferencia dos outros animais é o sentimento, e não a razão. O bicho humano é essencialmente moral, pois seu comportamento racional estará sempre sujeito a juízos sobre o Bem e o Mal. Nenhum outro ente no mundo pode ser assim apreciado em termos de sua bondade ou maldade intrínsecas."

"Portanto, temos características que nos são únicas e exclusivas. Além da liberdade como fonte da vida ética, só o humano é dotado de vontade, de preferências valorativas, de autonomia, de autoconsciência como o oposto da alienação. Só ele tem a memória e a consciência de sua subjetividade, de sua história no tempo e no espaço e se enxerga como um sujeito no mundo, "orgânico" e mortal. Só o humano pode desenvolver suas virtualidades no sentido da cultura e do auto aperfeiçoamento, vivendo em sociedade e expressando-se através do amor, da razão e da criação estética, qualidades essencialmente comunicativas. É sabido que certos animais, como os gorilas e os cães, tem emoções de amor, ciúme, lealdade - mas o ser humano é o único que vive em perpétua transformação, pela memória do passado e pelo projeto do futuro. Sua unidade existencial significa que, seguindo Kant, ele é único e insubstituível"318

O neoliberalismo desenfreado ampliou o abismo entre os que tem e os que não tem levando a tensão social aos países cuja desigualdade é mais evidente, produzindo diversos efeitos pouco desejados como a criminalidade, a violência decorrentes da frustação por não pertencer ao mundo dos que tem. E essas tensões somente tendem a se agravar com as repetidas crises do sistema econômico.

World capitalism has postponed its crisis but only at the cost of transforming it into an international crisis. The danger is now not civil war within individual States provoked by intolerable conditions within those States, but international war provoked ultimately by the misery of the majority of mankind who daily

${ }^{318}$ COMPARATO, F. K. e BENEVIDES, M.V. - A Dignidade Humana como fonte de Direitos, in Gilda Maciel de Barros (org.) Estudos em homenagem a professor Celso de Rui Beisiegel. São Paulo: EDUSP, 2009, p. 210. 


$$
\text { grow poorer and poorer. }{ }^{319}
$$

Pois, o propósito firmado na DUDH e encampado pela DEFDH - de diminuir as diferenças construídas historicamente e reconhecer as desigualdades naturais - deverá seguir na contramão do sistema econômico-social vigente na atualidade. $\mathrm{O}$

(...) principio da solidariedade esta na base dos direitos econômicos e sociais, que a Declaração consagra nos artigos 22 a 26. Trata-se de exigências elementares de proteção às classes ou grupos sociais mais fracos ou necessitados. Sucedeu, porém, que, a partir do ultimo quartel do século 20, o movimento de globalização capitalista, apoiado na propaganda universal do chamado neoliberalismo, enfraqueceu sobremaneira, em quase todos os países, o conjunto desses direitos. ${ }^{320}$

Dessa forma, a tarefa para a DEFDH ao se propor a construir uma cultura dos direitos humanos é romper com todos os valores e princípios alterando em sua essência toda a sociedade ao combater o sistema patriarcal. Somente desta maneira poderemos vivenciar uma sociedade que busque verdadeiramente estreitar as diferenças em busca de uma possível e realística igualdade do seres humanos.

Assim sendo, a satisfação do principio da igualdade e sua comunhão com os da dignidade e liberdade, continua sendo um dos maiores obstáculos - se não o maior - para a adesão aos direitos humanos e sua consequente efetivação. A noção de igualdade e a aceitação da real desigualdade - temas centrais para a superação desta diferenciação entre os seres humanos - é fundamental para se construir uma sociedade mais igualitária em conformidade com suas diferenças históricas e naturais.

\subsection{Sobre o multiculturalismo}

Segundo a DEFDH,

La educación y la formación en materia de derechos humanos debe abarcar, enriquecer e inspirarse en la diversidad de las civilizaciones, religiones, culturas y tradiciones de los diferentes países, reflejada en la universalidad de los derechos humanos. ${ }^{321}$

Juntamente com a preocupação sobre a definição de EDH, assunto mais abordado nos relatórios de participação, o tema do multiculturalismo esteve presente em praticamente todos os comentários durante o processo de elaboração da DEFDH sem importar a origem geográfica ou tradição cultural, ou mesmo se eram oriundos dos

\footnotetext{
${ }^{319}$ NKRUMAH, Kwame. Neo-Colonialism, the last stage of imperialism. 1965. Open Acess. Disponível em http://www.marxists.org/subject/africa/nkrumah/neo-colonialism/conclusion.htm. Acessado em 07.01.2011.

${ }^{320}$ COMPARATO, 2008, p. 16.

${ }^{321} \mathrm{DEFDH}$, artigo $5^{\circ}, 3^{\circ}$.
} 
Estados, INDHs, sociedade civil, etc. ${ }^{322}$, o mesmo valendo para temas ligados à diversidade cultural - como a etnia e a religião - e em relação à diferença, a tolerância, o conviver, o respeito, entre outros. A diversidade cultural foi indicada como obstáculo frequentemente o maior - despontando como uma prioridade para a EDH, mas, sobretudo, como desafio para a sua efetivação. ${ }^{323}$

Os direitos humanos são universais, porém essa universalidade deve respeitar as distintas culturas e seus meios para a introdução dos próprios valores dos direitos humanos.

Analisamos brevemente o patriarcado como sistema social predominante nas sociedades modernas. Anterior a isto, no inicio desta obra, comentamos sobre o nacionalismo e as dificuldades enfrentadas para a quebra da soberania absoluta. Tratamos destes temas posto que a matéria é internacional. A ONU é a união de nações uma vez que, quando da sua criação, já era essa a distribuição da sociedade humana - dividida de acordo com a grandeza do mundo e o distanciamento dos continentes.

Assim, separadas espacialmente, as sociedades desenvolveram-se em línguas, costumes e tradições distintas. Certamente, existem diversidades de culturas pelo simples fato de haver diversidade de povos.

\begin{abstract}
A cultura é constituída pelo conjunto dos saberes, fazeres, regras, normas, proibições, estratégias, crenças, ideias, valores, mitos, que se transmite de geração em geração, se reproduz em cada individuo, controla a existência da sociedade e mantem a complexidade psicológica e social. Não há sociedade humana, arcaica ou moderna, desprovida de cultura, mas cada cultura é singular. Assim, sempre existe a cultura nas culturas, mas a cultura existe apenas por meio das culturas. ${ }^{324}$
\end{abstract}

As culturas, ao entrarem em contato uma com as outras, podem tanto absorver quanto rechaçar suas características. A cultura tem caráter mutável, isto é, está em constante transformação decorrente dos novos acontecimentos dentro da sociedade na qual ela se desenvolve. Estas novas ocorrências são de causa interna ou externa, neste caso, produto da relação com outra cultura.

As culturas são aparentemente fechadas em si mesmas para salvaguardar sua identidade singular, Mas, na realidade, são também abertas: integram nelas não

\footnotetext{
${ }^{322}$ Governos de Túnis, Bruxelas, Amsterdã.

${ }^{323}$ Neste sentido: India is a very large and populous country. Furthermore it is quite diverse. People speak different languages and also follow different customs and tradition in different parts of the country. Hence imparting human rights education and developing training material becomes quite a challenging job. There is also a shortage of resource persons on some specialized issues particularly those who can impart training in vernacular languages.

${ }^{324}$ MORIN, Edgar. Os sete saberes necessários à educação do futuro. Tradução Catarina Eleonora F. Da Silva e Jeanne Sawaya. $11^{\text {a }}$ edição. São Paulo: Cortez; Brasília, DF: UNESCO, 2006, p. 56.
} 
somente os saberes e técnicas, mas também ideias, costumes, alimentos, indivíduos vindos de fora. As assimilações de uma cultura pela outra são enriquecedoras. $^{325}$

As sociedades humanas sempre interagiram, quer em colaboração, quer em conflito. Desde o inicio, os motivos pelos quais os povos migram gerando o encontro das civilizações são os mesmos: as guerras, os conflitos, a miséria e a fome, a busca por agua, a fuga de regimes opressores, as pestes e epidemias, o comercio e os negócios, a exploração dos bens materiais, a escravidão, etc. A interação entre os povos enriquece as culturas, cria outras, colabora para a superação de problemas comuns, mas também massacra, extingue e escraviza.

Em decorrência a esses encontros negativos - presentes desde sempre - deriva a xenofobia, definida por desconfiança, temor ou antipatia por pessoas estranhas ao meio daquele que as ajuízam ou pelo que é incomum ou vem de fora do país. Curiosamente, no entanto, a palavra xenofobia - xen(o) + fobia - de origem grega, traz o prefixo Ksenos que significa "estrangeiro" ou "hospede". Ou seja, etimologicamente, o Kseno poderia representar o hospede, isto é, alguém de fora que convive pacificamente em casa ou hospedaria por determinado tempo. Não obstante, o medo do desconhecido - fundado ou construído - faz com que o estrangeiro - no sentido do diferente - passe a ser temido como uma ameaça. Este temor subjetivo é estimulado dentro da sociedade comumente como ferramenta para manipulação das percepções coletivas com o objetivo de dar popularidade a regimes e governantes e, sobretudo, para justificar sistemas opressores e interesseiros.

Foi no século XV que a distancia entre os continentes foi eliminada pelo ciclo das grandes navegações e o avanço do comercio decorrente desta possibilidade resultou no inicio do processo de mundialização, internacionalização, ou, em outra palavra, globalização. O contanto entre as civilizações, contudo, criou ou perpetuou vários problemas decorrentes desta interação. Todos esses processos, representados especialmente pela experiência do colonialismo e o neocolonialismo, resultaram em maior interação internacional marcada negativamente, simultaneamente à miscigenação de costumes línguas e etnias distintas.

A forma com que os europeus lidaram com a diferença étnica em relação a determinados povos - em especial os negros africanos e os índios americanos - demonstra claramente o cenário que as ideias baseadas no eurocentrismo justificavam. Os "selvagens" 
não eram civilizados dentro da moralidade sócio-religiosa europeia. Propunha-se que, por não conhecerem o deus dos brancos, nem alma tinham, sendo assim, nem humanos eram e, desta feita, poderiam ser dispostos como os animais que, afinal, foram criados para atender ao ser supremo da natureza: o homem.

O racismo (ou a ideia de superioridade entre etnias) não desapareceu por mais que tentativas de teorias eugênicas fossem desmentidas cientificamente. Em que pese ser absurdo, mentiroso, desumano, o racismo ainda está muito longe de desaparecer nas sociedades contemporâneas e atende a propósitos de interesse do sistema social vigente.

Conforme vimos anteriormente, os direitos humanos surgiram na Europa em decorrência dos eventos históricos ocorridos ali, em especial, suas guerras e revoluções. Por este motivo, muitos governantes de países (orientais normalmente) apontam os direitos humanos como uma ingerência na cultura e tradições locais, como fizeram os europeus com outros temas em suas colônias. O eurocentrismo existe, sem sombra de duvidas, e foi a justificativa para a politica responsável pela destruição de inúmeras culturas em todo o mundo e, como o racismo, é ainda facilmente observado nos dias atuais, com a diferença que seu maior estandarte está no continente norte-americano.

Os direitos humanos, contudo, não podem ser listados nesta categoria (de imposição eurocêntrica) pelo único fato de ser uma construção em conjunto - Os Estados-membros da ONU assinaram e ratificaram a DUDH, demonstrando assim conformidade com os valores contidos nela.

Embora o argumento que são os direitos humanos uma imposição cultural europeia seja de fácil contestação, o eurocentrismo é utilizado por lideres em diversos países - cuja a cultura não foi totalmente dominada pela europeia - como uma desculpa para a não adesão aos direitos humanos, enaltecendo ou o espirito nacional ou dogmas étnico-religiosos importantes para levantar a alto-estima de povos oprimidos, sendo certo que tal corrupção do significado dos direitos humanos é francamente utilizada como ferramenta de manipulação social.

Nesta mesma linha, acusam os direitos humanos de serem uma bandeira cristã e, mais especialmente hoje em dia, serem uma imposição dos EUA e sua famigerada politica internacional, por mais antagônico que isso possa soar. Em contrapartida, a agenda da Guerra ao terrorismo encabeçada pela politica internacional estadunidense, determina que o inimigo do momento é o muçulmano radical, frequentemente violando direitos humanos em nome da segurança nacional. 
Além disto, os processos de colonização resultaram na criação de minorias étnicas nacionais, tanto nas metrópoles como nas colônias. Mais recentemente, com o avanço da internacionalização observado nas ultimas décadas - principalmente a globalização econômica e o domínio das empresas transnacionais - a migração não coletiva, ou seja, aquela que apenas indivíduos e suas famílias migram para outros países, dispara, resultando em um maior numero de estrangeiros nos países, formando colônias, onde é possível observar na pratica a interação de costumes, tradições e línguas, nem sempre pacifica.

É inegável que este processo avança o cosmopolitismo, sem embargo, esta diferenciação, ou seja, a do estrangeiro (ou pertencente à etnias distintas) contrapõe-se com a figura do nacional, acrescentando mais uma diferença à afirmação "somos todos iguais", ao lado do gênero e do status social. E este fenômeno é reproduzido tanto em esfera internacional como nacional.

Existem, na verdade, vários tipos de globalização: negativas e positivas. A ONU, por exemplo, é um processo de globalização, como o são os direitos humanos, e, como vimos, o processo internacional de EDH.

Devido ao processo de internacionalização, as culturas locais tenderiam a absorver a cultura transnacional. Com este processo em franca aceleração, as diferenças culturais tenderiam à adaptação à tendência internacional, o que era esperado principalmente no tocante ao Direito Internacional por se tratar de uma obrigação e não de uma absorção volitiva. No entanto, certas características da globalização não confirmaram ainda o esperado. Não ao ponto de sustar violações sistemáticas de direitos humanos.

Segundo Boaventura de Souza Santos, a globalização assume o seguinte padrão: “os países centrais especializam-se em localismos globalizados, enquanto aos países periféricos cabe tão-só a escolha entre varias formas alternativas de globalismo localizado ou localismos globalizados". ${ }^{326}$ Define localismos globalizados, como o processo pelo qual um fenômeno local é globalizado, "seja a atividade mundial das multinacionais, a transformação da língua inglesa em língua franca, a globalização do fast food americano ou de sua musica popular (...).,327

Segundo ele, a globalização ainda pode ser o globalismo localizado que

\footnotetext{
${ }^{326}$ SANTOS, Boaventura de Sousa. Reconhecer para libertar: os caminhos do cosmopolitismo multicultural. Rio de Janeiro: Civilização Brasileira, 2003, pp. 435-436.

${ }^{327}$ Ibid., p. 435.
} 
consiste no impacto especifico de praticas e imperativos transnacionais nas condições locais, as quais são, por essa via, desestruturadas e reestruturadas de modo a responder a esses imperativos transnacionais. ${ }^{328}$

Os direitos humanos, segundo sua visão, estariam englobados pelo movimento do cosmopolitismo, que é o

“...conjunto muito vasto e heterogêneo de iniciativas, movimentos e organizações que partilham a luta contra a exclusão e a discriminação sociais e a destruição ambiental produzidas pelos localismos globalizados e pelo globalismo localizado, recorrendo a articulações Sul-Sul' novas formas de intercambio operário; redes transnacionais de lutas ecológicas, pelos direitos da mulher, dos povos indígenas, pelos direitos humanos em geral (...) cosmopolitismo é a solidariedade transnacional entre grupos explorados, oprimidos ou excluídos pela globalização hegemônica., 329

No cosmopolitismo encontramos a cidadania universal que a EDH visa promover para consertar a ordem internacional que claramente é responsável por violações destes e pela destruição implacável do patrimônio comum da humanidade. ${ }^{330}$

A globalização frequentemente é apontada como o grande mal da sociedade, por ser compreendida unicamente como a ação indiscriminada das empresas transnacionais, ou seja, o globalismo localizado, sem que se leve em consideração os múltiplos tipos de globalização, incluindo a própria $\mathrm{ONU}$.

A DEFDH vem com o proposito de estimular o entendimento entre as nações ao combater a xenofobia e o racismo através da EDH. Tem ela, portanto, a missão de evoluir na formação da cidadania internacional ao atacar os mecanismos de perpetuação do sistema opressor, neste caso, a deturpação da diversidade étnica e cultural.

Isso significa assumir a complexidade do humano, ou seja, ser capaz de lidar com as diversas faces, reconhecendo na forma de ser do humano a multidiversidade de suas expressões. Se existem diferenças, elas são complementares, e não são incontornáveis à própria cultura na forma de se

\footnotetext{
${ }^{328}$ Opus citatum. E continua: Tais globalismos localizados incluem enclaves de comercio livre ou zonas francas; desmatamento e destruição maciça dos recursos naturais para pagamento de divida externa; tesouros históricos, lugares ou cerimonias religiosas, artesanato e vida selvagem postas à disposição da indústria global do turismo, dumping ecológico ("compra" pelos países do terceiro mundo de lixo tóxico produzidos nos países capitalistas centrais para gerar divisas externas); conversação da agricultura de subsistência em agricultura de exportação como parte do "ajuste estrutural”; alterações legislativas e politicas impostas pelos países centrais ou pelas agencias multilaterais que elas controlam; uso de mão de obra local por parte de empresas multinacionais sem qualquer respeito por parâmetros mínimos de trabalho (labor standards)

${ }^{329}$ SANTOS, 2003, p. 436.

${ }^{330}$ Ibid., p. 437. E continua: Trata-se de temas que só fazem sentido em relação ao globo na sua totalidade: a sustentabilidade da vida humana na Terra, por exemplo, ou temas ambientais como a proteção da camada de ozônio, a preservação da Antártida, da biodiversidade ou do fundo do mar (...). Todos esses temas referem-se a recursos que, pela sua natureza, deveriam ser geridos por fideicomissos da comunidade internacional em nome das gerações presentes e futuras.
} 
encontrarem modos de interação e integração. ${ }^{331}$

Objetivamente, o desafio é a adaptação da EDH às culturas locais. Esta questão foi ressaltada durante o processo de elaboração da DEFDH, indicando que os direitos humanos são suscetíveis à mudanças de acordo com os lugares, tempos e sociedades, como são as necessidades humanas.

\begin{abstract}
"Human rights are liable to change with changes of places, times and societies as well as changes in human needs, even though the Charter with its broad headlines is the controlling conductor for the track and eventualities of the rights. Nevertheless, special margins of freedom must be set aside for communities to approach such rights in the form that suits their special circumstances but does not conflict with the essence of the rights as being anchored in dignity and value of the human being no matter who or where he or she may be. "332
\end{abstract}

A adaptação dos direitos humanos à cultura local e vice-versa, deve ser apenas de meio e nunca do fim. Isto é, eles devem se adaptar à cultura local, mas objetivando seu respeito integralmente.

$\mathrm{Na}$ busca por um caminho que leve à plena absorção dos direitos humanos através da EDH, estes devem encontrar relação pacifica com as religiões, que, como sabemos, têm importante papel na conformação social. A este respeito, foi sugerido (por mais perigoso que isso possa soar) que se valorize as grandes religiões e as tradições culturais na promoção dos direitos humanos através da observância de outras ações iniciadas no seio da ONU como o "Diálogo entre Civilizações" e sua reformulação através da "Aliança entre Civilizações."

Assim sendo, os direitos humanos devem encontrar harmonia no relacionamento com as religiões dada a sua importância na formação de mentes. A aproximação da religião dos direitos humanos, contudo, não pode prescindir de cautela. $\mathrm{O}$ resultado pode ser desde pequenas consequências como o risco de - com a aproximação demasiada dos direitos humanos com os ritos culturais e religiosos - a EDH limitar-se somente aos dias festivos ${ }^{333}$, como podem, ademais, muitos preceitos religiosos serem contrários aos direitos humanos, e nesta hipótese haver prevalência da visão religiosa sobre a mundana.

\footnotetext{
${ }^{331}$ BITTAR, Eduardo Carlos Bianca. Quem é estrangeiro no mundo dos homens? IDE versão para impressão ISSN 0101-3106 Ide (São Paulo) v.31 n.47. São Paulo dez. 2008. Disponível em http://pepsic.bvsalud.org/scielo.php?pid=S0101-31062008000200020\&script=sci_arttext. Acessado em 07.01 .2012

${ }_{332}$ Educational Center for Research and Development (Líbano).

333 "some subjects, for example religion, ethics, history and social studies, contain specific human rights education. Schools may also organize different kind of projects, celebrations and thematic days in order to promote human rights. However, it is important that human rights education should not be limited to special days only. INDH Finland"
} 
Não se pode falar em multiculturalismo sem deixar de mencionar a diversidade de religiões no mundo e os fundamentalismos de toda a espécie, especialmente na atualidade com a chamada guerra ao terrorismo, cujo inimigo, especificamente, é o "terrorista muçulmano" fundamentalista e sua $j i h a d^{334}$. É certo que muitos “ensinamentos" religiosos são contrários às ideias dos direitos humanos. Fundamentalismos podem ser observados nas mais variadas ramificações das grandes religiões. Sem querer aprofundar neste tema, entendemos tratar-se mais de apropriações de deuses e profetas em nome de manipulação social das massas e, por outro lado, da criação de inimigos que justifiquem o injustificável. De qualquer maneira, muitos relatórios não deixaram que o Comitê se olvidasse da questão $^{335}$. Destaque para o relatório do Vaticano ${ }^{336}$ que, além de descrever suas atividades educacionais em direitos humanos pelo mundo, através das universidades católicas, afirma que as dimensões ética e religiosa são parte fundamental do princípio holístico da educação integral. "A fundamental part of this holistic principle of integral education is the ethical and religious dimension: an education in human rights must approach religious experience in a favourable way, giving it full house room, on the same footing as other choices."

Não se trata apenas de problemas de entendimento cultural entre as nações, mas sim da interação dos direitos humanos com as distintas culturas que, espalhadas, envolvidas, incorporadas, misturadas, enfim, presentes nas maiorias das sociedades da atualidade, devem conviver no mesmo espaço e tempo, e os desafios a serem enfrentados estendem-se, além de encontrar harmonia entre concepções e entendimentos, a materializar e modelar a EDH em condições de diversidade cultural. ${ }^{337}$

Finalmente, a DEFDH vem para colaborar no processo de reconhecimento da beleza da diversidade cultural e da ratificação da cultura internacional de direitos humanos,

\footnotetext{
${ }^{334}$ Jihad é o termo em árabe para luta

${ }^{335}$ Por exemplo: "If the UN insists that in every country human rights should be compulsory subject which should be taught to every child. It should also be included in the madrasa teachings where only Islamic education is given". Hotline Bangladesh.

${ }^{336}$ Identificada nos relatórios como Santa Sé no francês Saint Seige.

${ }^{337}$ Bom exemplo de atenção à multiculturalidade é o caso do governo hondurenho, que informa que sua prioridade era dar atenção aos grupos étnicos através do PRONEEAAH - programa nacional para las Etnias Autóctonas y Afro Antillanos de Honduras - incluindo-se a produção de material didático na língua nativa dos oito povos indígenas de Honduras. A França soma que suas prioridades são “... la lutte contre les discriminations, fondés de les plus jeune âge sur l'apprentissage du respect de soi et des autres, est une des priorités de l'éducation aux droits de l'homme. Já a INDH canadense alude que o multiculturalismo está presente na política estatal canadense desde 1985, no entanto, ainda são grandes as dificuldades para a superação deste obstáculo, dada a diversidade de povos indígenas e a amplitude de seu território ${ }^{337}$. Além disso, o Canadá é um país receptor de novos grupos migrantes vindos de países variados, desde a Armênia até o Zimbábue, o que aumenta ainda mais o espectro da atenção à multiculturalidade na EDH.
} 
buscando harmonia entre os vários elementos que configuram a cultura local $\mathrm{e}$ a compreensão do mundo, não somente o lado negativo, mas sim o combate a ele através das iniciativas de reafirmação dos direitos humanos. Neste sentido, a DEFDH vem somar-se à outras iniciativas da ONU que não se omitiu em tentar trabalhar o tema do multiculturalismo empreendendo esforços na sistematização de dispositivos sobre o tema $^{338}$. Em verdade, a própria DUDH definiu, em 1948, que "toda a pessoa tem o direito de tomar parte livremente na vida cultural da comunidade, de usufruir as artes e de participar no progresso científico e nos benefícios que deste resultam." Posteriormente, as iniciativas da ONU - através da UNESCO - para incrementar o pensamento cosmopolita, respeitando as diversidades, também incluem a Declaração sobre Raça e Preconceito Racial, de 1978, e a Convenção Universal sobre a Proteção e a Promoção das Diversidade Cultural e das Expressões Artísticas, em 2005.

Trata-se de formidável exercício de equacionar a questão da universalidade dos direitos humanos como elemento central de uma cultura humana universal e o respeito às diversidades culturais. Desinformadamente,

(...) os que veem a diversidade das culturas tendem a minimizar ou a ocultar a unidade humana; os que veem a unidade humana tendem a considera como secundaria a diversidade das culturas. Ao contrario, é apropriado conceber a unidade que assegure e favoreça a diversidade, a diversidade que se inscreve na unidade. ${ }^{339}$

Portanto, um meio caminho há de ser encontrado para equilibrar as relações interculturais, quebrando paradigmas construídos com base no medo do diferente como forma de manutenção do estado das coisas.

Por isso, diante da étrangeté (strangness), a globalização deve reagir de modo a ser capaz de absorver o alto grau de insegurança, drenando-o para dentro de esforços coletivos de superação das diferenças e criação de canais de evasão dos mitos, muitas vezes criados, muitas vezes fundados, de que o outro é um inimigo natural. Para isso, temos de ser capazes de convencermo-nos de que civilização e barbárie só existem onde é possível criar as formas de determinação do que é ser civilizado e do que é ser bárbaro. Isso significa que precisamos superar a forma colonialista de definir o encontro intercultural e passarmos a prezar na diferença do outro esta alteridade que deve ser reconhecida como humana, e igualmente sujeita ao respeito, ao deferimento do esforço psíquico de sua compreensão. Aí está um exercício moralmente fundado de irrestrito respeito à diferença e prática de tolerância. ${ }^{340}$

Somente com a superação destes temores do diferente, através da EDH, os direitos

\footnotetext{
${ }^{338}$ Cf Declaração sobre os Direitos das pessoas pertencentes a minorias nacionais ou étnicas, religiosas e linguísticas de 1992 e a Declaração sobre a Eliminação de Todas as Formas de Intolerância e Discriminação fundadas na Religião ou Convicções de 1981.

${ }^{339}$ MORIN, 2006, p. 57.

${ }^{340}$ BITTAR, 2008.
} 
humanos poderão encontrar terreno para sua expansão livre de obstáculos e preconceitos contrários a eles.

Por isso, se o direito tem de seguir algum rumo, nos descaminhos da atual política vigente globalmente, o seu rumo é certamente o de tentar mudar o rumo das coisas. E isso porque, no mundo da humanidade, ninguém deveria ser estrangeiro. $^{341}$

\subsection{As construções sociais da realidade e a anticultura de direitos humanos.}

A DEFDH tem como objetivo final criar uma cultura universal dos direitos humanos reafirmando na prática o princípio da universalidade deles em ordem mundial. Esse foi o objetivo maior para a iniciativa de elaborar um documento internacional sobre a EDH. Confirmaram esta leitura praticamente a totalidade dos 149 questionários analisados. A falta de uma cultura de direitos humanos foi observada como um dos maiores obstáculos para a promoção deles, desarranjo que deve ser consertado através da EDH em todos os níveis, incluindo campanhas, expressões artísticas e culturais, os meios de comunicação ou qualquer forma de difusão dos seus ideais ${ }^{342}$.

A ONG FIMARC, por exemplo, acrescentou a essa idéia que a situação atual do mundo; as crises econômicas, financeiras, alimentarias, energéticas, etc., abrem caminho mais facilmente para violações de direitos humanos que para a EDH. A preocupação pela ausência de uma cultura dos direitos humanos foi compartilhada pelo Estado grego em relação à desilusão dos jovens estudantes em seu país e como eles enfrentam os desafios atuais $^{343}$.

Muito bem, foi consenso, então, que a DEFDH deve colaborar decisivamente para o estabelecimento da cultura dos direitos humanos. No entanto, conforme vimos, as sociedades atuais desenvolveram-se sob o sistema social patriarcal e com forte influencia do nacionalismo. Com o "fim do socialismo", o neoliberalismo tornou-se o único paradigma político-econômico que acompanha o processo de internacionalização, incluindo-se ai os direitos humanos. O desenvolvimento deste sistema politico têm-se mostrado catastrófico em termos de direitos humanos, porém, certamente, permitidor do

\footnotetext{
${ }^{341}$ BITTAR, 2008.

${ }^{342}$ Por exemplo, concorda o Estado senegalês quando afirma que o maior desafio é Summonter les obstacles socioculturels pour instaurer une véritable culture des droits humains.

343 “... we hold that it still remains a challenge for students to learn to live together and respect diversity in practice. Inclusion has yet a way to go and the role of education as a driver of social cohesion and economics prosperity needs to be further reinforced. The focus should be on broader equity issues such as the reduction of early school-leaving and drop-outs, gender balances, adult education and social and labour mobility."
} 
acúmulo e da concentração de riqueza com base na exploração, discriminação e opressão das classes desfavorecidas. Ou seja, é mecanismo muito interessante para a classe dominante.

O objetivo da DEFDH é alterar este cenário ao transformar corações e mentes através da EDH. Contudo, o sistema vigente dispõe de implacável aparato de sedimentação de conceitos a serviço do controle e manipulação das massas, em plena atividade, preparados para rejeitar ideias que ameacem o sistema. Trata-se de uma elaboradíssima engenharia maquiavélica de construções sociais baseadas na ignorância e na alienação isto é, na falta da educação - através da criação de mitos, fantasias e preconceitos; verdades (como são transmitidas) que justificam o fato de alguns terem tanto e muitos terem tão pouco, ou mesmo nada.

A primeira construção é a naturalização e a imutabilidade do status quo. A cultura é transmitida de geração em geração através do seus símbolos, títulos e bens. O instituto da herança garante certa estabilidade dentro das camadas mais elevadas da sociedade. Esse mito do mundo dado acaba por acalentar certas inquietudes humanas, sendo, os que o questionam, convocados a deixar isso de lado, pois o mundo é, sempre foi, e sempre será assim.

O pensamento da imutabilidade apresenta uma brecha, por assim dizer. O status quo é imutável mas não para aqueles que trabalharem duro, já que no sistema liberal, todos são iguais e livres para, através do trabalho, acumularem riqueza, ascendendo às classes sociais dominantes. Essa exceção à imutabilidade é, na pratica, uma concessão das classes dominantes - como, de certa maneira, pode ser interpretado o próprio Direito - que aceitam alguns para não aceitar a todos.

Por conta do patriarcado, temos a figura do poder soberano e que a ele tudo cerca. $\mathrm{O}$ homem serve somente a deus, porque, afinal, ele também o é ${ }^{344}$. O homem rico é a ponta da pirâmide do poder, e esse poder é medido pelo quanto se pode comprar. O dinheiro, definitivamente, transformou-se no maior agente interseres. É ele que regula as relações sociais humanas em detrimento a qualquer outro meio, como sentimentos ou relações amistosas e amorosas. A sociedade, ao naturalizar a competição e a ganância, justifica todos os seus absurdos e se mantem através da engenharia da sedução e do patético. ${ }^{345}$

Nela, vigora o fascínio pelos signos de prestigio e de poder, como se observa no

\footnotetext{
344 ao menos nas maiores religiões do mundo Deus sempre se apresenta com uma figura masculina.

${ }^{345}$ no sentido de doente.
} 
uso de títulos honoríficos sem qualquer relação com a possível pertinência de sua atribuição, o caso mais corrente sendo o uso do "Doutor" quando, na relação social, o outro se sente ou é visto como superior ("doutor" é o substituto imaginário para os antigos títulos de nobreza); ou como se observa na importância dada a manutenção de criadagem domestica cujo numero indica aumento de prestigio e status, etc. (...) ${ }^{346}$

A vida cotidiana apresenta-se como uma realidade interpretada pelos homens e subjetivamente dotada de sentido para eles na medida em que forma um mundo coerente ${ }^{347}$. Isto é, os valores transmitidos através da educação, das tradições, e da língua, por exemplo, estão a serviço das classes mais favorecidas para a manutenção dos seus benefícios, o que resulta na cultura contraria aos direitos humanos que observamos na maioria das sociedades. Estes valores referenciais são transmitidos através da educação, dos discursos políticos, discursos de "celebridades", sobretudo, através dos meios de comunicação. Por este motivo, a DEFDH determina que a EDH deve permear todos os níveis e estar presente em qualquer atividade educativa ou comunicativa.

Estes meios acabam por formar o senso comum sobre a realidade que admite como certas as "verdades" transmitidas e, a partir daí, tende a defende-las.

O mecanismo de controle, dessa maneira, institucionaliza ideias contrarias aos direitos humanos sempre que há uma tipificação reciproca de ações habituais por tipos de atores. A repetição é meio pelo qual estes valores são incutidos na mentes dos indivíduos. Estas construções sociais da realidade (ou distorções dela) servem para encobrir os elementos de injustiça e opressão e valem no trato a todos os tipos de desigualdade, quer seja de gênero, social ou étnica.

Seguindo este mecanismo de produção de verdades, são naturalizadas as desigualdades salariais, entre homens e mulheres ou entre diferentes etnias, o trabalho infantil ou do idoso, a falta de atenção aos portadores de deficiência, etc. Aos pobres é atribuída culpa pela sua condição desfavorável, sendo a miséria comumente atribuída à preguiça ou incapacidade e, portanto, culpa dos próprios que, neste pensamento e segundo a meritocracia, afinal, poderiam trabalhar duro para "subir na vida."

A anticultura encontra exemplo claro na concepção popular do brasileiro: os direitos humanos são para os "bandidos", entendimento expresso na expressão "direitos dos mano", onde "mano" representaria a forma de tratamento entre os criminosos, na gíria paulistana.

\footnotetext{
${ }^{346}$ CHAUÍ, 2008, p. 74.

${ }^{347}$ BERGER, P. L. e LUCKMANN, T. A Construção Social da Realidade: tratado de sociologia do conhecimento. Tradução de Floriano de Souza Fernandes. Petrópolis: Vozes, 1985. p. 35.
} 
Dessa maneira, seduzidos - ao serem convidados à riqueza através do trabalho -, no caso brasileiro, a grande massa tende a rechaçar a ideia dos direitos humanos por ser ela atrelada aos direitos unicamente daqueles que cometeram crimes. Os defensores das realidades construídas prontamente virão com sua pergunta "xeque-mate": "e os direitos humanos das vitimas?", o que demonstra a total incompreensão do que são, de fato, os direitos humanos, ou sua declarada distorção.

Os que são seduzidos pelo sistema, estimulados pelo conservadorismo e pelas ideias retrógradas, tradicionais, acabam por se tornar defensores dele, tendendo a excluir os direitos humanos da possibilidade de ideias. Aos que não se seduzem pelo sistema e optam por questiona-lo, outra forma de tratamento é dispensada: a opressão.

Os ordenamentos jurídicos são de tal maneira organizados para estabelecer duvida quanto a sua titularidade e seu objeto, atendendo aos anseios da classe dominante em uma sociedade.

\begin{abstract}
Nela as leis sempre foram armas para preservar privilégios e o melhor instrumento para a repressão e a opressão, jamais definindo direitos e deveres concretos e compreensíveis para todos. No caso das camadas populares, os direitos são sempre apresentados como concessão e outorga feitas pelo Estado, dependendo da vontade pessoal ou do arbítrio do governante. Essa situação é claramente reconhecida pelos trabalhadores quando afirmam que "a justiça só vale para os ricos" ${ }^{348}$.
\end{abstract}

A elucidação das leis, portanto, está a cargo da autoridade. Nada pode contrariar o ditado por ela por motivos lógicos: a autoridade se legitima por "conhecer" o subterrâneo, as mensagens subjacentes, o sistema invisível - e, portanto, é a única capaz de preencher as lacunas do desconhecimento jurídico. O desejo da autoridade deve ser interpretado como a verdade. ${ }^{349}$ Daí advém a dificuldade da efetivação da EDH porque, como vimos, é o Estado o maior responsável por ela.

Sem embargo, a anticultura dos direitos humanos começa em casa nas relações de poder. O problema da mentalidade patriarcal é que ela é formada no seio da família, portanto, através da primeira experiência educativa da criança. A DEFDH e os instrumentos internacionais tratam da responsabilidade material da família de matricular seus filhos na escola e dar lhes condições para frequentar as aulas, rendendo liberdade na escolha do tipo de educação, etc., porém, não dão conta de tratar da situação da família ser instrumento de perpetuação de ideias contrárias aos direitos humanos e contrárias,

\footnotetext{
${ }^{348}$ CHAUÍ, 2008, p. 70.

${ }^{349}$ GUTERMAN, Marcos. “A Instituição da paranoia. O Estado de São Paulo, São Paulo, 4 de jun. 2011. Sabático, p. 5.
} 
consequentemente, ao que se aprenderia na EDH nas escolas ${ }^{350}$. O mesmo vale para a localidade e comunidade educativa. Ao mesmo tempo, graças ao caráter transformador da educação, é possível sim que os filhos eduquem os pais, ou as crianças eduquem os adultos, como alias, ocorre atualmente no aprendizado do uso das novas tecnologias de informação ou sobre temas ambientais, por exemplo.

Aos meios de comunicação, no entanto, foi concedida, pela DEFDH, mais atenção pelo alcance deles e, consequentemente, a influencia na formação da cultura.

\begin{abstract}
Ademais, a sociedade pós-moderna, ou sociedade da informação, é a sociedade em que as coisas não são o que são, mas são aquilo que são tornadas. (...) Há muita circulação de informação e baixa densidade reflexiva: a tecnologia domina o cenário da informação. Os jogos de imagem definem a essência e constituem as coisas. Por isso, na sociedade da informação, mas importante que o fenômeno é a sua aparência na mídia. ${ }^{351}$
\end{abstract}

Nos dias de hoje, com a revolução da informação, a mídia extrapolou a sua importância e significado, sendo considerada o maior meio de profusão de ideias na maioria das sociedades. Isto não é novidade, mas o surgimento da internet foi capaz de, em uma década, conectar o mundo de uma maneira antes impensada. Além disso, as crianças hoje passam mais tempo em frente aos televisores que com seus professores ou com os pais e familiares, elevando a importância da televisão e outros meios na formação da cultura $^{352}$. Atenta a este fato, a DEFDH inovou na importância dada aos meios de comunicação ao colar à definição de EDH dois outros direitos humanos: a liberdade de expressão e o direito à informação. O primeiro é fundamental para o exercício da educação e para difusão de ideias dos direitos humanos. Por sua vez, o direito à informação é definido pelo direito de informar, informar-se e ser informado. Informar significa garantir liberdade de imprensa e meios para que agentes de comunicação possam exercer esse direito livremente. Informar-se é o direito que todos tem de buscar informações, seja através da liberdade de imprensa, seja pelos órgãos públicos.

$\mathrm{O}$ direito à informação vem sendo violado frequentemente na chamada "guerra ao

\footnotetext{
${ }^{350}$ Confédération Française des Travailleurs Chrétiens: A partir de l'expérience française il apparaît que la question de la responsabilité et de la liberté d'éduquer ses enfants en cohérence avec sa culture et ses convictions, affirmée à l'article 26 - 3 de la Déclaration universelle des droits de l'homme, est une question d'importance et à mettre en valeur. En effet les parents doivent pouvoir exercer concrètement cette liberté et cette responsabilité sans subir de discrimination morale ou matérielle. Même en France, où ce droit est garanti de façon globalement satisfaisante, il doit être suivi attentivement car il a fait régulièrement l'objet de contestations dans le passé.

${ }^{351}$ BITTAR, 2008.

${ }^{352}$ The fact that many children now spend more time with screens than with teachers (or with their parents) also affects human rights learning. While the technology is value-neutral, the messages picked up or sent may not be. Efforts by the school in the field of human rights may be undermined by impressions on the screen, often dictated by purely commercial interests.
} 
terror", por exemplo. Sob este pretexto, "suspeitos" de terrorismo podem ser detidos sem justificativa e sem comunicação com parentes ou advogados, violação escancarada do direito ao devido processo legal, tendo como maior exemplo, indubitavelmente, a experiência estadunidense na cubana Guantánamo ${ }^{353}$.

A política de segredo do Governo dos Estados Unidos em relação as atrocidades cometidas em Guantánamo e Abu Ghraib é reveladora de quanto a informação está assumindo um papel central na proteção dos direitos humanos. Corroborando essa idéia - a contrario sensu - a pouca divulgação das consequências do embargo econômico ao Iraque e também a imprecisão das informações relativas a presença de armas nucleares e de destruição em massa. ${ }^{354}$

E quem controla a mídia e, dessa forma, a informação? Os mass media monopolizam a informação, controlando o conteúdo dos programas. O consenso é confundido com a unanimidade, de sorte que, a discordância é posta como ignorância ou atraso, atendendo aos interesses das classes dominantes.

Diante da impossibilidade de se conhecer a outra cultura senão pelo écran dos televisores, acredita-se naquilo que se tona o relato-da-verdade. Este relato parcial se torna formativo, opinativo, e quando não muito se torna também fonte oficial de informação para deliberações governamentais. Principalmente nas circunstancias de conflitos, destacam-se três fontes de informação: mídia internacional (inglesa, americana, principalmente), informações do exércitos ou das forcas armadas (o próprio ocupador fazendo o relado de sua atuação) e jornais locais (necessariamente partidários e sectários). Qual a possibilidade de se reunir qualquer tipo de aproximação com a verdade? ${ }^{355}$

Tanto em esfera internacional, quanto nacional, a mídia está concentrada nas mãos dos grupos mais poderosos dentro da sociedade. Com esta poderosa ferramenta, o processo de construção da realidade é trabalhado constantemente, criando e formulando mitos, determinando a quem pertence a riqueza do mundo.

Invariavelmente, padrões de verdade se associam a "padrões de beleza" e, por consequência, a "padrões de feiura". A feiura daquele que não é , é a expressão ou indicio de seu não pertencimento e, portanto, de sua condição de não ser. A feiura se atrela não somente a padrões estéticos, ou avaliações biofísicas, mas a padrões de convivência politica, em que todo o exotismo pode ser utilizado de modo caricato como forma de politização da diferença. Nesta condição, o outro se torna a expressão da danação, do medo. ${ }^{356}$

Conforme observamos no subcapitulo anterior, o medo é o elemento mais eficaz neste processo de manipulação que ganhou os traços que reconhecemos atualmente no fim da Idade Media. Como vimos, nos séculos seguintes à Idade Media a "Europa passou da

353 Cf o relatório da Anistia Internacional Guantánamo: A Decade of Damage to Human Rights. Disponível em https://www.amnesty.org/en/news/guantanamo-decade-damage-human-rights-2012-01-11, acessado em 10.01.2012.

354 ALMEIDA, G. A. Soberania, cosmopolitismo e o direito internacional dos direitos humanos (DIDH). Disponível em http://www.nevusp.org/downloads/down075.pdf. Acessado em 07.12.2011.

355 BITTAR, 2008.

${ }^{356}$ BITTAR, 2008, loc. cit. 
fragmentação politica e da semi-estagnação econômica e cultural ao expansionismo dos descobrimentos, ao esplendor da Renascença e do Iluminismo, à pujança das revoluções industriais, à hegemonia global, ao imperialismo"357.

\begin{abstract}
A inquisição foi o triunfo da organização burocrática para o estabelecimento de uma atmosfera de terror que tinha como objetivo manter a sociedade sob controle politico e ideológico feroz, em quatro continentes. Estabeleceu a culpa como algo inescapável, e quem ousasse resistir a isso enlouqueceria em sessões de tortura ou ardia nas fogueiras "purificadoras". Sobretudo, estabeleceu que o real não existia mais, senão como elaboração das autoridades eclesiásticas. ${ }^{358}$
\end{abstract}

Apesar de a Inquisição ser atribuída unicamente à igreja, tratava-se, na verdade, de uma politica de Estado. "O poder da Inquisição crescia ou declinava segundo o poder de ação dos monarcas - quanto mais os reis precisavam de controle e riqueza, mais a violência inquisitorial se expandia." ${ }^{, 359}$. Como de costume, o sistema de invenção de inimigos servia para mascarar problemas internos, neste caso, o declínio acelerado dos impérios ibéricos. A inquisição teria, para muitos, formado as origens do racismo moderno e consolidado o sistema patriarcal ${ }^{360}$. As ideias etnocêntricas acompanharam este processo, acelerado com o ciclo das navegações, aumentando o contato do europeu com o nãoeuropeu.

Preparado no borbulhante caldeirão cultural de um mundo em transição, o Demônio chegou ao apogeu na Inquisição dos séculos XVI e XVII não como um resquício da Idade Media, mas como legitimo - e necessário - personagem da Modernidade recém-iniciada. Produto de uma civilização que se via predestinada a levar a aurora da salvação, da ciência e da razão - quase sempre pelo fio da espada e à bala - aos confins do planeta, imersos na noite do pecado e da ignorância ${ }^{361}$.

Incrivelmente, os mesmos mecanismos de formação de pensamento continuam a utilizar das mesmas ideias. Como vimos, o estimulo à xenofobia ainda é forma com a qual governantes conseguem ganhar apoio popular para suas ações militares ou outras, nacional ou internacionalmente.

Quando, por exemplo, George W. Bush conclama as nações e os homens de bem a lutar, com a aprovação de Deus, contra o "eixo do mal", num ambiente que já não mais comporta não-alinhados e meios tons. Num ato falho do marketing politico, o mesmo Bush chegou a chamar a luta contra os terroristas, e supostos

\footnotetext{
${ }^{357}$ LOBO, Flavio. Lúcifer o Conquistador. Revista Carta Capital. São Paulo. 17 de abril de 2002, p.14

${ }^{358}$ GUTERMAN, 2011, p. 5.

${ }^{359}$ GUTERMAN, 2011, loc. cit. .

${ }^{360}$ LOBO, 2002, p.16: A inquisição, que teve seu ápice nos séculos XVI e XVII, "provinha de um catolicismo que intensificava sua conquista das populações europeias em geral, e não das onde as de uma pretensa "mare de satanismo" evocada pela historiografia religiosa oficial" Seu alvo preferencial, que inicialmente haviam sido membros do próprio clero, passaram a ser as ditas "feiticeiras demoníacas"

A partir do final do século XVI e ate meados do século XVII, a Inquisicao passou por sua fase mais violenta na maior parte da Europa. A demonologia, que norteava as perseguições, julgamentos, suplícios e execuções, concentrou-se em questões relativas à sexualidade feminina, considerada "contraria a natureza".

${ }^{361}$ Ibid., p. 14.
} 
terroristas, de Cruzada. Mancada esclarecedora, mas logo corrigida, por força da necessidade de buscar o apoio de parte do mundo árabe. ${ }^{362}$

Com os desmandos dos EUA, uma onda anti-islã tomou o mundo. Pessoas que antes não tinham ideia da existência do Islamismo, logo determinaram o muçulmano como o inimigo da vez. Maomé, de profeta, passou a ser o chefe dos terroristas para ocupar o lugar antes preenchido pelo "russo comunista", que, com o fim da guerra fria, passou para o lado do "bem", na visão falaciosa do processo de manipulação encampada internacionalmente pelos EUA e seus aliados.

No âmbito domestico, o mesmo sistema de criação de inimigos, baseado no medo, faz de todo o pobre o potencial inimigo. No caso brasileiro, o traficante de drogas é o nosso terrorista.

A manipulação também ocorre em esfera econômica. As noticias são fabricadas e as crises propagadas como forma de conter os anseios das classes menos favorecidas. Assim, o Brasil, por exemplo, apesar de um dos países mais ricos do mundo, na concepção popular, era um país pobre, incapaz de combater a miséria de seu povo por falta de recursos.

A crise econômica mundial iniciada em 2008 é outro bom exemplo.

O colapso dos bancos foi tratado como fruto de anomalias, desvios, passiveis de ser corrigidos. Hoje, o fio condutor já é a catástrofe em si mesma, como se ela fosse um desastre natural, e não o resultado da ação humana. Assim, a queda num setor acaba sendo explicada pela queda em outro.

Manchetes revelam como os editores querem que o leitor receba a noticia. Direcionam o modo de leitura, e muitos leitores ficam só nas manchetes ${ }^{363}$. Dessa maneira, a mídia é controlada para gerar anseios e desanima-los, em um jogo de oferta e tomada continuo. Os mitos, medos e superstições são produzidos conforme o interesse que devem atender.

\footnotetext{
Uma das edições do principal jornal de economia do pais, "Valor Econômico," trouxe no inicio de março nada menos que 15 manchetes e títulos com a palavra "crise". Era "crise" para todo o lado, quando havia e quando não havia. "Teles lucram mais apesar da crise". Se lucram mais, não há crise para elas, então por que dizer "apesar da crise". Ou "Mesmo com crise, JBS aposta nos EUA". Ou ainda: "Contra a crise Volvo investe na AL". Nessas manchetes, o fato noticiado é a negação da crise, mas o sentido transmitido é de crise. ${ }^{364}$
}

Por estes motivos, foi dada atenção ao papel da mídia (mesmo que indiretamente) por entender, a DEFDH, ser ela a maior ferramenta das classes dominantes para a

${ }^{362}$ LOBO, 2002, p. 19.

${ }^{363}$ Como exemplo disso vemos a reputação do MST e os ataques constantes sobre sua politica de ocupação, chamada pela mídia sempre de invasão.

${ }^{364}$ KUCINSKI, Bernardo. Uma narrativa do fim do mundo. Revista do Brasil, n ${ }^{\text { }}$ 34, abril de 2009, p. 11. 
formação da opinião publica e do senso comum, estrategicamente arquitetada para a manutenção do status quo e notadamente contraria aos direitos humanos.

A mídia deve respeitar os direitos humanos. Sua programação deveria conter elementos que contribuam para o processo educativo da EDH. Sem embargo, notamos que o problema fundamental não é somente o conteúdo contrario, mas a manipulação de toda a mídia.

Esse é um dos desafios para a efetivação da EDH; superar este obstáculo demandará reformas no controle da mídia o que, de certa forma, começa a acontecer com a internet. Apesar de as grandes corporações já dominarem a rede mundial de computadores, ela tem características abertas, dando liberdade para a comunicação e difusão de ideias, independente destes grupos econômicos poderosos.

A adesão das culturas aos ideais dos direitos humanos é, além de todo o já exposto, complementar à democracia. A manipulação é encampada para dar a sensação ao indivíduo que a politica está aberta ao seu acesso, quando de fato, nenhum mecanismo que garanta ou estimule esse acesso é posto em pratica para as classes menos favorecidas. $\mathrm{Na}$ linguagem da filosofia poderíamos dizer que na estranheza do povo em relação a democracia se reflete a alienação da sociedade em relação a si mesma. ${ }^{365}$ Por esta razão

\section{(...) it seems that some governments fear that a human rights approach in the schools could breed unwanted criticism and even undermine government policies. This is an undemocratic and short-sighted attitude. Educating citizens in their human rights creates an informed society which in turn strengthens democracy. For the Council of Europe, therefore, human rights education is crucially important.}

Mas a democracia desacompanhada de um povo educado, não se estabelece a ponto de constar da experiência das pessoas como se fosse um assunto próprio delas, de modo que elas compreendessem a si mesmas como sendo sujeitos dos processos políticos. Ela é reduzida ao sufrágio e não expandida à participação politica em nenhum nível.

Para mudar todo este cenário, surge a DEFDH. Para interferir neste processo de formação de mentes, combatendo os preconceitos, os estigmas, as verdades construídas, ratificando os valores éticos-morais da DUDH, avançando no cosmopolitismo em contrapartida ao estado atual das coisas.

A escola, neste cenário, perpetua este sistema excluidor posto que ele está presente na cultura. A escola comum, ou a educação praticada nela, é o mais puro reflexo da

\footnotetext{
${ }^{365}$ ADORNO, Theodor W. Educação e emancipação. Tradução de Wolfgang Leo Maar. São Paulo: Paz e Terra, 2010. p. 35.
} 
sociedade na qual ela é desenvolvida. "Consecuentemente, el propósito de la escuela fue y todavía lo es en muchos sentidos, la consolidación y diseminación de consumidores y consumidoras, con capacidades controladas de reacción social. "366

Para que esta realidade mude, primeiramente, será preciso dar aos educandos a prerrogativa de pensar. Para a mudança de valores proposta, a educação deve fazer conhecer o que é conhecer. Este conhecimento é necessário para que o individuo desenvolva senso critico, permitindo-o questionar certas verdades. Contrariamente a essas ideias, matérias como a filosofia e sociologia, vem, ao longo do tempo, desaparecendo dos currículos, inclusive em nível superior.

\footnotetext{
É impressionante que a educação que visa a transmitir conhecimentos seja cega quanto ao que é o conhecimento humano, seus dispositivos, enfermidades, dificuldades, tendências ao erro e à ilusão, e não se preocupe em fazer conhecer o que é conhecer. ${ }^{367}$
}

A tendência à mercantilização afeta diretamente à educação. Seu proposito sob o regime liberal patriarcal é formar alguém preparado para vencer, o que significa, em seu pensamento, acumular riqueza. Isso é mais observado nas escolas particulares, que, dentro de uma relação mercantil devem entregar o serviço, cujo proposito é dar condições e alimentar habilidades para o acumulo.
A ordem econômica e, seguindo seu modelo, em grande parte também a organização econômica, continuam obrigando a maioria das pessoas a depender de situações dadas em relação as quais são impotentes bem como se manterem em uma situação de não emancipação. ${ }^{368}$

E estes valores estão obviamente constantes da educação moderna, que, como sabemos, criou a ilusão da igualdade de oportunidades.
Partiendo de la premisa de ese status quo inamovible, la escuela de hoy conlleva a la validación y mantenimiento del actual estado de cosas y de valores patriarcales que la propasan, respondiendo solamente a las necesidades de las estructuras de poder. Por esta razón, los sistemas educativos tienden a ser excluyentes y violadores de los derechos humanos, ofreciendo un modelo de escuela que uniforma, que rechaza la diferencia, que aniquila lo plural, el reconocimiento del otro y que se torna propensa a discriminación institucionalizadas. $^{369}$

Será através da EDH nas escolas é que se reduzirá a violência no mundo, o racismo, a xenofobia e se promoverá a integração dos grupos minoritários na sociedade, particularmente em países do sul, afirmou, preciosamente a ONG haitiana Réseau des Citoyens Haïtiens pour la Promotion des Droits de l'Homme.

\footnotetext{
${ }^{366}$ MUÑOZ, 2009, p. 8.

${ }^{367}$ MORIN, 2006, p. 14.

${ }^{368}$ ADORNO, 2010, p. 43.

${ }^{369}$ Ibid., 2009, p. 2.
} 
L'éducation et la formation aux droits de l'homme sont les seuls remparts pour réduire la violence dans le monde, le racisme, la xénophobie dans les écoles et l'intégration des groupes minoritaires dans la société. La formation aux droits de l'homme est très important pour les pays du Sud qui accusent un déficit au niveau du développent de la culture des droits de l'homme. ${ }^{370}$

A condição humana deveria ser o objeto essencial de todo o ensino. E educação deve ser um processo revelador, emancipatório. Deve-se ensinar a verdade das sociedades a partir da DUDH, aprofundando nos temas ligados a ela, suas causas e efeitos. Este estudo é tanto mais necessário porque enfocaria não os sintomas, mas as causas do racismo, da xenofobia, do desprezo ${ }^{371}$, por exemplo.

A educação deve conduzir à "antropo-ética", levando em conta o caráter ternário da condição humana, que é ser ao mesmo tempo individuo/sociedade/espécie. Nesse sentido, a ética individuo/espécie necessita do controle mutuo da sociedade pelo individuo e do individuo pela sociedade, ou seja, a democracia; a ética individuo/espécie convoca, ao século XXI, a cidadania terrestre.

O cenário atual, reprodutor da desigualdade construída, não é de fácil conserto. Fazse necessária uma verdadeira revolução já que envolvem mudanças estruturais para a substituição de uma cultura por outra. Em nosso entender, nenhum estudioso poderia jamais prescindir da educação como ferramenta de mudança.

A educação é transformadora e emancipatória. A EDH é reveladora e conscientizadora. Pessoas que são expostas à EDH tendem a demonstrar cooperação e solidariedade. Revelando as verdades construídas, os seres humanos podem encontrar o caminho para sua realização ${ }^{372}$. Estes são os propósitos da DEFDH. “A pratica de declarar direitos significa, em primeiro lugar, que não é um fato obvio para todos os homens que eles são portadores de direitos e, por outro, que não é um fato obvio que tais direitos devam ser reconhecidos por todos.” Com ela, a EDH ganhará espaço nas agendas politicas servindo como referencial para a reinvindicação de uma educação de qualidade e emancipadora.

Por fim, a EDH vem para colaborar com este movimento de formação da cidadania cosmopolita contrario ao movimento de globalização econômica liberal que condena bilhões de pessoas à inferioridade, alheias à distribuição da riqueza, exploradas, oprimidas.

\footnotetext{
${ }^{370}$ Réseau des Citoyens Haitiens pour la Promotion des Droits de l'Homme.

${ }^{371}$ MORIN, 2006, p. 17.

372 TIBITTS, 2007, p. 6: Children who learn about the Convention and about the rights of the children show more rights-respective attitudes toward other children and towards adults. In particular, they indicate more positive attitudes toward minority children (Covel \& Howe, 1999; Decoene \& De Cock, 1996 as quoted in Covell, O'Leary \& Howe, 2002). A study carried out on the Facing History programs showed that young people who participated in the program grew in psychosocial competencies in their interpersonal and intrapersonal skills (Barr, 2005).
} 
Trata-se de um projeto de humanização de todos posto que

A desumanização, que não se verifica, apenas, nos que tem sua humanidade roubada, mas também, ainda que de forma diferente, nos que a roubam, é distorção da vocação do ser mais. É distorção possível na historia, mas não na vocação histórica. Na verdade, se admitíssemos que a desumanização é a vocação histórica dos homens, nada mais teríamos que fazer, a não ser adotar uma atitude cínica ou de total desespero. A luta pela humanização, pelo trabalho livre, pela desalienação, pela afirmação dos homens como pessoas, como "seres para si”, não teria significação. Esta somente é possível porque a desumanização, mesmo que um fato concreto na historia, não é porém, destino dado, mas resultado de uma "ordem" injusta que gera a violência dos opressores e esta, o ser menos. ${ }^{373}$

${ }^{373}$ FREIRE, Paulo. Pedagogia do Oprimido. $17^{\text {a }}$ Ed. Rio de Janeiro: Paz e Terra, 1987. p. 30. 


\section{Considerações Finais}

Conforme vimos, apesar de não conter mecanismos jurídicos para sua efetivação, a DEFDH deve representar mais um passo em direção ao avanço dos direitos humanos. Passo este que, apesar da falta de força vinculante, deve ser imprescindível para a mudança real e decisiva das sociedades atuais.

Ao longo deste trabalho, pudemos observar, mesmo que em síntese, a predominância do sistema patriarcal nas sociedades modernas, violento, opressor, explorador, discriminador e segregador, onde uma certa elite financeira goza de privilégios conquistados através de meios espúrios de exploração do outro - considerado negativamente diferente, inferior aos donos da riqueza e do poder - situação que encontra terreno fértil permitido pelo sistema socioeconômico vigente baseado na ganancia e no acumulo permanente de riqueza, através da criação e reafirmação de desigualdades construídas e da negação ou desrespeito às desigualdades naturais, uniformizando quando interessar. Em outras palavras: somos iguais ou diferentes de acordo com o interesse das classes dominantes e não de acordo com os fatos observados na realidade.

Vimos também que a educação praticada sob esse sistema naturalmente tende a reforça-lo e defende-lo atendendo aos propósitos assinalados pela classe dominante, em pleno serviço da manutenção do status quo.

Em contraposição, estamos submetidos, enquanto sociedade, a um sistema internacional de direitos humanos que objetiva garantir igualmente a todos os indivíduos a liberdade e a dignidade, protegendo-os das violações cotidianas em todas as esferas. Este sistema vem pretendendo a incorporação de seus valores na sociedade, através de leis e praticas sociais e, mais precisamente com a DEFDH, a absorção dos princípios e valores dos direitos humanos pela população em geral, isto é, a sua internalização através da educação,

Transcorridos mais de sessenta anos da DUDH, essa internalização não foi satisfatoriamente efetiva, variando de país para país, de acordo com sua realidade políticosocial.

É senso comum apontar a educação como ferramenta de transformação das sociedades, podendo haver outros meios, mas que dificilmente, prescindem de qualquer atividade educacional. 
A EDH deverá superar as desigualdades, ou, melhor dizendo, deverá equaciona-las reconhecendo as naturais diferenciando-as das construídas pelos próprios homens ao longo da sua historia. Deverá combater - ao lado de outros instrumentos $-{ }^{374} \mathrm{o}$ patriarcado e todo o modo de pensar dos homens e mulheres na sociedade sob esse sistema.

Ainda sobre o principio da igualdade, entendemos a EDH deverá apontar que as diferenças socioeconômicas em uma sociedade não necessitam condenar bilhões de pessoas à fome, à miséria e ao abandono social.

Deverá promover o respeito às desigualdades naturais e sua aceitação como parte da diversidade humana dedicando atenção especial a elas, na mesma linha de pensamento de tratar igualmente os iguais e desigualmente os desiguais, sempre com o proposito de consertar injustiças históricas responsáveis pelo não estreitamento da desigualdade entre os seres humanos de uma sociedade.

Deverá atacar veementemente a manipulação das consciências pelos meios de comunicação de massa, pelo consumo inexplicável, pela indústria da opinião publica, dando ao educando autonomia na formação do seu pensamento, buscando entender quais são as regras responsáveis pela opressão e a perpetuação da injustiça.

Alguns apontam que por ser a própria ordem internacional uma operação das classes dominantes, ela seja condenada ao fracasso. Segundo este pensamento, toda a ordem internacional é corrupta em sua própria formação e por isso incapaz de alcançar o objetivo proposto por ela. A ONU não busca a paz. A ONU busca a não destruição humana. É um problema de gênese. Dessa maneira, o sistema sempre operará às margens do limite para a eclosão de novas guerras e levantes, buscando a paz que interessa ao Alto da sociedade.

Para o estabelecimento de uma cultura de direitos humanos que, certamente, não será construída da noite para dia, imaginamos que a mudança somente será possível se partindo das classes menos favorecidas às dominantes, seguindo as ideias freirianas.

Mas, pode não ser o caso de novo rearranjo. A ordem internacional embora imperfeita, com certeza, funcionaria perfeitamente através de novos homens e mulheres. Não é que não preparamos a ordem internacional, é que não nos preparamos para a ela, principalmente para a adesão dos seus valores e princípios, incorporando-os no modo de pensar que tem nos direitos humanos a salvaguarda do proposito maior desta ordem, qual seja a paz do próprio ser humano.

${ }^{374}$ Em especial a Convenção Sobre a Eliminação de Todas Formas de Discriminação contra a Mulher. 
A revolução cultural necessária para a mudança da nosso realidade é proposta pela EDH ao estabelecer como objetivo a tão almejada e necessária cultura dos direitos humanos, ratificando seu proposito maior: fazer valer os direitos previstos na DUDH e demais instrumentos internacionais.

Outros, ainda, defendem que a positivação dos direitos é somente estratégia das classes dominantes justamente para o seu não cumprimento. A DEFDH acalenta, por certo período, a insatisfação dos que lutam por esse direito, passando a ser um ideal a ser alcançado mas impedido por situações que virão a surgir no futuro, tais como a falta de recursos para a efetivação de cada direito. Porém, o que deve ser entendido é que com a positivação e o não cumprimento, as classes prejudicadas com o sistema podem, se conscientes destes direitos, ir às ruas e derrubar o sistema. E isso começa a ocorrer em todo o mundo através de diferentes agendas.

Vivemos a era das transformações. A revolução da tecnologia e consequentemente da informação, impõem velocidade nunca antes vista às transformações politicas e sociais. O mais nítido exemplo é a "primavera árabe"- nome que batiza os movimentos populares nos países árabes - responsáveis pelo desmonte de ditaduras de décadas, como foram as revoluções na Tunísia e no Egito e a guerra civil na Líbia, eventos impensáveis em tão curto período antes da possibilidade proporcionada pela internet.

Entretanto, as revoluções não garantem necessariamente uma mudança positiva ou a concretização das pretensões das classes protagonistas. Por exemplo, o temor de, com estas revoluções árabes, ascenderem ao poder fundamentalistas religiosos, transformando sociedades socialmente injustas em autocracias religiosas tão ou mais injustas e, desta forma, agravarem ainda mais a situação dos direitos humanos, como o ocorrido no Irã dos Aiatolás.

Além de orientar as revoluções, quer culturais, quer sócio-politicas, a EDH tem a missão de combater, por exemplo, a ascensão da retomada das ideias nazistas na Europa, a guinada às politicas xenófobas de extrema direita, como notado na Áustria, Holanda, Dinamarca, Canadá, entre outros. Virá para combater o consumismo como religião e a religião como consumo, a liberdade absoluta que gozam as instituições financeiras, as empreiteiras, os latifúndios, etc..

Seria de extrema ingenuidade pensar que a DEFDH por si só será capaz de mudar todo o cenário descrito neste texto. Sem embargo, devemos recordar que a Declaração surge como resultado e mais uma etapa do movimento crescente de valorização da EDH 
notadas nas ultimas décadas e como a afirmação da comunidade internacional e o desejo de mudar o mecanismo destruidor de gentes e do planeta.

De igual sorte à DUDH - que vinha com o temor da possibilidade da destruição atômica - a DEFDH é acompanhada pelo temor que os processos produtivos e o consumo exagerado poderá, em pouco tempo, destruir o mundo, ao menos como o conhecemos hoje.

A pratica politica da declaração de direitos ocorre em ocasiões muito precisas. De fato, as declarações de direito ocorrem em situações revolucionarias, isto é, naqueles momentos em que o baixo da sociedade se revela contra o alto e não mais reconhece a ordem vigente injusta. A DEFDH propõe uma revolução pacifica capaz de inaugurar um novo "iluminismo", liderado pelas classes desfavorecidas e não por interesses burgueses.

Estas possibilidades de revolução trazem ainda mais importância à EDH posto que mudança significa a transformação decorrente de certos fenômenos, não implicando necessariamente, transformação positiva.

A transferência dos direitos humanos para figurar como um dos paradigmas a serem seguidos pela sociedade, formando os indivíduos, desde suas primeiras experiências educativas, deve absorver a ideia que todos os indivíduos do planeta têm o direito a tudo o quanto foi resumido como necessidade ou desejo humano expresso na DUDH.

Às classes menos favorecidas cabe a missão de transformar o mundo.

Ao compreenderem que estão submetidos a um sistema injusto e opressor, seus membros menos privilegiados descobrem que não são, ab initio, culpados por sua situação e esta revelação libera-os de uma perversa carga psicológica negativa que sempre os acompanhou. Somente isso já é um resultado positivo da EDH.

Os conhecimentos adquiridos devem empoderar os indivíduos para que esta conscientização leve ao aumento da alto-estima mas, sobretudo, que vise à mudança do estado atual das coisas, sendo ferramenta - talvez a única - capaz de transformar este mundo horrível em um lugar em que se possa, de uma vez por todas, concluir o projeto de humanidade que, até os dias atuais, segue sendo apenas um projeto. 


\section{REFERENCIAS BIBLIOGRAFICAS.}

ADORNO, Theodor W. Educação e emancipação. Tradução de Wolfgang Leo Maar. São Paulo: Paz e Terra, 2010.

ABBAGnANO, Nicola. Dicionário de filosofia. $5^{\text {a }}$ Ed. Trad. Ivone Castilho Benedetti. São Paulo: Martins Fontes, 2007.

ALMEIDA, G. A. Soberania, cosmopolitismo e o direito internacional dos direitos humanos (DIDH). Núcleo de Estudos da Violência - USP. Disponível em http://www.nevusp.org/downloads/down075.pdf. Acessado em 07.12.2011.

ALVES, José Augusto Lindgren. A Arquitetura internacional dos direitos humanos. São Paulo: FTD, 1997.

ARENDT, Hannah. As origens do totalitarismo. Trad. Roberto Raposo. São Paulo: Companhia das Letras, 1989.

. Eichmann em Jerusalém: Um relato sobre a banalidade do mal. São Paulo: Companhia das Letras, 1999.

. A condição humana. 10 a Ed. Rio de Janeiro: Forense Universitária, 2001.

Homens em tempos sombrios. São Paulo: Cia. Das Letras, 1987.

ARIES, P. e Duby, G. (Orgs) Historia da vida privada. v. 5. São Paulo: Companhia das Letras, 2009.

BENEVIDES, M. V. A cidadania ativa. São Paulo: Ática, 1991.

Fé na luta: a comissão justiça e paz de São Paulo, da ditadura à democratização. São Paulo: Lettera.doc, 2009. 
BITTAR, E. C. B.. O Direito na pós-modernidade. São Paulo: Forense Universitária, 2005. (DFD - 340.12 B541d 2.ed.)

Quem é estrangeiro no mundo dos homens? IDE versão para impressão ISSN 0101-3106 Ide (São Paulo) v.31 n.47. São Paulo. dez. 2008. Disponível em http://pepsic.bvsalud.org/scielo.php?pid=S0101-31062008000200020\&script=sci_arttext. Acessado em 07.01.2012

BOBBIO, Norberto. A era dos direitos. Trad. Carlos Nelson Coutinho. Rio de Janeiro: Elsevier, 2004.

; MATTEUCCI, N.; PASQUINO, G.. Dicionário de politica I. Trad. Carmen C. Varriale et ai. Coord. Trad. Joao Ferreira e Luis Guerreiro Pinto Cacais. $11^{\text {a }}$ Ed. Brasília: UNB, 1998.

BROWNLIE, Ian; CBE; QC; FBA. Principles of International Law. $7^{\text {th }}$ Ed. New York: Oxford University Press, 2008.

CARVALHO, J.S.F., (Org.). Educação, cidadania e direitos humanos. Petrópolis, RJ: Vozes, 2004.

CHAUÍ, Marilena. Cultura e democracia. in: Crítica y emancipación: Revista latinoamericana de Ciencias Sociales. Año 1, no. 1 (jun. 2008). Buenos Aires : CLACSO, 2008 . Disponível em http://bibliotecavirtual.clacso.org.ar/ar/libros/secret/CyE/cye3S2a.pdf. Acessado em 07.01.2011.

COMPARATO, Fabio Konder. A afirmação historia dos direitos humanos. $7^{\mathrm{a}}$ Ed.. São Paulo: Saraiva, 2010.

. Os 60 anos da Declaração e nossa Constituição. Brasil direitos humanos. 2008: A realidade do país aos 60 anos da Declaração Universal. Artigos Entrevistas e reportagens. Secretaria Especial dos direitos humanos da presidência da república. 
; e BENEVIDES, M.V.. A Dignidade humana como fonte de direitos, in Gilda Maciel de Barros (org.) Estudos em homenagem a professor Celso de Rui Beisiegel,SP: EDUSP, 2009, pp 207-218.

CRETELlA NETO, José. Teoria geral das organizações internacionais. V. 1. São Paulo: Saraiva, 2007.

FREIRE, Paulo. Pedagogia da autonomia: saberes necessários à prática educativa. São Paulo: Paz e Terra, 2002.

GOLDSMITH, Jack L. e POSNER, Eric A. The Limits of international law. New York: Oxford University Press, 2005.

GUTERMAN, Marcos. “A Instituição da paranoia. O Estado de São Paulo, São Paulo, 4 de jun. 2011. Sabático.

KANT, Immanuel. Para a paz perpetua. Trad. Barbara Kristensen. Galícia: IGESIP, 2006.

KEINON, Herb, “US, Israel quit Durban.” The Jerusalem Post, Jerusalem, 03 Sept 2001. Disponível em http://www.ngo-monitor.org/article.php?operation=print\&id=1026. Acesso em 07.01.2012

LAFER, C.. A Reconstrução dos direitos humanos. São Paulo: Cia. das Letras, 2001.

LEWANDOVSKI, Enrique Ricardo. Globalização, regionalização e soberania. São Paulo: Ed. Juarez de Oliveira, 2004.

LOBO, Flavio. Lúcifer o Conquistador. Revista Carta Capital. São Paulo. 17 de abril de 2002. 
MAQUIAVELII, Nicola. O príncipe. Trad. Livio Xavier. $27^{\mathrm{a}}$ Ed. Rio de Janeiro: Ediouro, 1996.

MENEZES, C.A.; CANÇADO TRINDADE, A. A; PEREIRA, A. C. A. (Orgs) Novas perspectivas do Direito Internacional contemporâneo: estudos em homenagem ao professor Celso D. De Albuquerque Mello. $1^{\text {a }}$ Ed. Rio de Janeiro: Renovar, 2008

MÉSZÁROS, István. A educação para além do capital. Tradução de Isa Tavares. $2^{\mathrm{a}}$ Ed. São Paulo: Boitempo, 2008.

MORIN, Edgar. Os sete saberes necessários à educação do futuro. Tradução Catarina Eleonora F. Da Silva e Jeanne Sawaya. 11 a ed. São Paulo: Cortez; Brasília, DF: UNESCO, 2006.

MUÑOZ, Vernon. El mar entre la niebla: el camino de la educación hacia los derechos humanos. Costa Rica: Luna Hibrida Ediciones, 2009.

NASSER, Salem Kismat. Fontes e normas do Direito Internacional: Um estudo sobre a Soft Law. $2^{\mathrm{a}}$ ed. São Paulo: Atlas, 2006.

PIOVESAN, Flávia. Proteção Internacional dos Direitos Econômicos, Sociais e Culturais in: SARLET, Ingo Wolfgang (Org.). Direitos Fundamentais Sociais: estudos de direito constitucional, internacional e comparado. Rio de Janeiro: Renovar, 2003.

PIOVESAN, Flavia (coord.). Direitos humanos. $1^{\text {a }}$ ed., Curitiba: Juruá, 2007.

RAMIREZ, F. O.; SUAREZ, D.; MEYER, J.. The worldwide rise of human rights education. Stanford University, 2005. Open Access. Disponível em http://servidormanes.uned.es/mciud/eventos/articulos_rodr/Ramirez-Suarez-

Meyer_5_15_05_final\%202.pdf. Acesso em: 15 Mar. 2011.

REZENDE, A. P.; DIDIER, M. T.. Rumos da historia: historia geral e do Brasil. São Paulo: Atual, 2001. 
ROUSSEAU, Jean-Jacques. Do contrato social. São Paulo: Editora Martin Claret, 2000.

SEITENFUS, Ricardo. Manual das organizações internacionais. Livraria Casa do Advogado. Porto Alegre, 2008.

SANTOS, Boaventura de Souza. (Org.) Reconhecer para libertar: os caminhos do cosmopolitismo multicultural. Rio de Janeiro: Civilização Brasileira, 2003.

TIBITS, Felisa. Overview of research and evaluation within human rights education. In: HUMAN RIGHTS EDUCATION FOR SOCIAL CHANGE: EVALUATION APPROACHES AND METHODOLOGIES, 2007, Montreal, Canadá. Disponível em http://equitas.org/wp-content/uploads/2011/04/EQUITAS-Symposium2007-Final-

PRIN.pdf. Acessado em 06.01.2012.

TRINDADE, Antonio Augusto Cançado. O direito internacional em um mundo em transformação. Rio de Janeiro: Renovar, 2002.

WOLfF, R. P. Além da Tolerância. In A critique of pure tolerance. Zahar: Rio de janeiro, 1970.

Artigos e reportagens dos seguintes periódicos:

O Estado de São Paulo

Revista Brasil

Carta Capital

$\underline{\text { Sítios da internet: }}$

ANNAN, Kofi. $\quad$ Discurso. Disponível em http://portal.unesco.org/shs/en/ev.phpURL_ID\%3D7934\&URL_DO\%3DDO_TOPIC\&UR L_SECTION\%3D201.html. Acessado em 03.01.2012 
HUMAN RIGHTS WATCH. Disponível em www.hrw.org. Acessado em 04.01.2012.

UNOVA. Disponível em http://www.un.org/disarmament/WMD/Nuclear/. Acessado em 01.10 .2011

UNESCO. Disponível em http://www.unesco.org/new/en/. Acessado em 07.01.2012.

OFFICE OF THE HIGH COMMISSIONER FOR HUMAN RIGHTS - OHCHR Disponível em http://www.ohchr.org. Acessado em 07.01.2012. Acessado em 07.01.2012.

(MICHAELIS) DICIONÁRIO UOL-MICHAELIS ONLINE. Disponível em http://michaelis.uol.com.br/moderno/portugues/index.php. Acessado em 13.05.2010.

CAMBRIDGE DICTIONARY ONLINE - Cambridge University Press. Disponível em http://dictionary.cambridge.org/.

Documentos internacionais:

RESOLUCAO 1997/74 da extinta Comissão de Direitos Humanos. DECLARAÇÃO DE DURBAN. Disponível em http://www.un.org/WCAR/durban.pdf. Acessado em 04.01.2012.

RESOLUÇÃO 53/114 DA ASSEMBLEIA GERAL DA ONU Declaration on the Right and Responsibility of Individuals, Groups and Organs of Society to Promote and Protect Universally Recognized Human Rights and Fundamental Freedoms (de 9 de dezembro 1998). Disponível em http://www.un.org/depts/dhl/resguide/r53.htm. Acessado em 05.01.2012.

RESOLUÇAO 6/10 DO CONSELHO DE DIREITOS HUMANOS. Disponível em http://www2.ohchr.org/english/bodies/hrcouncil/advisorycommittee/HR_education_trainin g.htm. Acessado em 05.01.2012. 
http://www.politicheantidroga.it/media/313216/cndresolution_52_11.pdf. Acessado em 05.01 .2012 .

RESOLUÇÃO 2002/68 DA EXTINTA COMISSÃO DE DIREITOS HUMANOS. Disponível em ap.ohchr.org/documents/E/.../resolutions/E-CN_4-RES-2002-68.doc. Acessado em 05.01.2012.

RESOLUÇÃO 12/4 DO CONSELHO DE DIREITOS HUMANOS. Disponível em http://www2.ohchr.org/english/bodies/hrcouncil/12session/resdec.htm. Acessado em 05.01.2012.

RESOLUÇÃO 5/1 DE 1946 DO CONSELHO DE ECONOMICO E SOCIAL. Institutionbuilding of the United Nations Human Rights Council. Publicado em 18 Junho de 2007. Disponível em ap.ohchr.org/documents/E/HRC/resolutions/A_HRC_RES_5_1.doc. Acessado em 05.01.2012.

RESOLUÇÃO 60/251 DO CONSELHO DE DIREITOS HUMANOS. Disponível em http://www2.ohchr.org/english/bodies/hrcouncil/docs/A.RES.60.251_En.pdf. Acessado em 07.01.2012.

RESOLUÇÃO 7/14 DO CONSELHO DE DIREITOS HUMANOS. Disponível em http://ap.ohchr.org/documents/E/HRC/resolutions/A_HRC_RES_7_14.pdf. Acessado em 05.01.2012.

RESOLUÇÃO 7/28 DO CONSELHO DE DIREITOS HUMANOS. Disponível em http://ap.ohchr.org/documents/E/HRC/resolutions/A_HRC_RES_7_14.pdf. Acessado em 05.01.2012.

COMUNICACION 1/1 DO CONSELHO DE DIREITOS HUMANOS. Grupo de redacción sobre educación y formación en materia de derechos humanos: programa de trabajo. 
http://www2.ohchr.org/english/bodies/hrcouncil/advisorycommittee/docs/AC_Recommend ation_1_1_Spanish.pdf. Acessado em 04.01.2012.

RESOLUCAO A/52/469/Add.1 and Add.1/Corr.1 DA ASSEMBLEIA GERAL. “Guidelines for National Plans of Action for Human Rights Education” (UN Doc. A/52/469/Add.1 and Add.1/Corr.1). Disponível em http://ap.ohchr.org/documents/alldocs.aspx?doc_id=5280. Acessado em 05.01.2012.

RESOLUCAO E/CN.4/2004/93 p. 7, DA EXTINTA COMISSÃO DE DIREITOS HUMANOS. Disponível em http://daccess-ddsny.un.org/doc/UNDOC/GEN/G04/112/39/PDF/G0411239.pdf?OpenElement. Acessado em 05.01.2012.

RESOLUCAO A/59/525/Rev.1 DA ASSEMBLEIA GERAL. Disponível em http://www2.ohchr.org/english/issues/education/training/planaction.htm. Acessado em 05.01.2012.

RESOLUÇÃO 1997/74 DA EXTINTA COMISSÃO DE DIREITOS HUMANOS (substituída pelo Conselho de Direitos Humanos). Disponível em espanhol em http://www.unhchr.ch/Huridocda/Huridoca.nsf/0/03110241c34c274a80256649005c516c? Opendocument. Acessado em 07.01.2011.

RESOLUÇÃO DA ASSEMBLEIA GERAL 60/251, Protocolo facultativo 5 (a). Disponíveis em http://www2.ohchr.org/english/bodies/hrcouncil/docs/a.res.60.251_en.pdf. Acessado em 07.01.2012.

DECISÃO 6/102 DO CONSELHO DE DIREITOS HUMANOS. Disponível em http://www2.ohchr.org/english/bodies/hrcouncil/advisorycommittee.htm. Acessado 07.01.2012.

RESOLUÇÃO 2004/71 DA EXTINTA COMISSÃO DE DIREITOS HUMANOS 2004/71. 
http://www2.ohchr.org/spanish/issues/education/training/reports.htm. Acessado em 07.01.2011.

RESOLUÇÃO 59/113 DO CONSELHO DE DIREITOS HUMANOS. Disponível em http://www2.ohchr.org/english/bodies/hrcouncil/docs/17session/A.HRC.17.44_AUV.pdf. Acessado em 07.01.2011.

COMUNICAÇÃO DA ASSEMBLEIA GERAL A/59/525/Rev.1, Disponível em http://www2.ohchr.org/english/issues/education/training/planaction.htm. Acesso em 07.01.2012.

DOCUMENTO A/59/2005 DA ASSEMBLEIA GERA, § 182. Disponível em inglês em http://www2.ohchr.org/english/bodies/hrcouncil/docs/gaA.59.2005_En.pdf. Acessado em 07.01.2011.

RESOLUÇÃO 66/137 DA ASSEMBLEIA GERAL. Disponível em http://www2.ohchr.org/spanish/issues/education/training/UNDHREducationTraining.htm. Acessado em 04.01.2012. 


\section{ANEXO I - Marcos normativos da educação em direitos humanos}

1945 Criação da ONU.

1948 Declaração Universal dos Direitos Humanos.

1952 Seminário Internacional sobre Ensino dos Direitos Humanos (Países Baixos).

1953 Início do Projeto Escolas Associadas - UNESCO (UNESCO Associated Schools).

1966 Convenção Internacional sobre a Eliminação de Todas as Formas de Discriminação Racial.

1966 Pacto Internacional do Direitos Civis e Políticos.

1966 Pacto Internacional dos Direitos Econômicos, Sociais e Culturais.

1974 Recomendação da UNESCO sobre a Educação em Direitos Humanos.

1978 Criado o prêmio UNESCO para a Educação em Direitos Humanos.

1978 I Congresso Internacional sobre o Ensino dos Direitos Humanos, Viena.

1978 Resolução (78) 41 sobre o Ensino dos Direitos Humanos.

1979 Convenção Sobre a Eliminação de Todas as Formas de Discriminação Contra a Mulher.

1979 Encontro Ásia-Pacífico de especialistas em educação para a paz e direitos humanos.

1981 Carta Africana dos direitos do homem e dos povos (Banjul).

1982 Encontro de especialistas no Ensino dos Direitos Humanos (Estrasburgo).

1982 Convenção contra a Tortura e outras formas de tratamento cruel, desumano ou degradante.

1983 Conferencia Internacional sobre os direitos humanos e liberdades fundamentais (Paris).

1984 I Conferencia Latino Americana sobre Educação em Direitos Humanos (Venezuela).

1985 Recomendação R (85) 7 sobre o ensino dos direitos humanos nas escolas.

1987 Congresso Internacional sobre o ensino dos Direitos Humanos, Informação e Documentação, em Malta. 
1988 Protocolo adicional da Convenção Americana dos Direitos Humanos (protocolo de San Salvador).

1988 Campanha Mundial para a Publicização da Informação sobre Direitos.

1989 Convenção sobre os Direitos da Criança.

1989 I Encontro dos Diretores dos Institutos de Formação e Pesquisa sobre os Direitos Humanos.

1990 Declaração de Jomtien, Tailândia.

1992 Encontro Internacional sobre Educação em Direitos Humanos (República Tcheca).

1993 Congresso Internacional sobre Educação para os Direitos Humanos e Democracia (Canadá).

1993 Conferencia Mundial Sobre os Direitos Humanos; Convenção de Viena.

1993 Congresso Internacional sobre a Educação para os Direitos Humanos e a Democracia. Organizado pela UNESCO em Montreal.

1994 Criada a cátedra UNESCO de Educação em Direitos Humanos.

1994 Década da Educação para os Direitos Humanos da ONU (1994 - 2004).

1994 Declaração sobre o Ensino dos Direitos Humanos - Plano de Ação Integrado sobre a Educação para a Paz, os Direitos Humanos e a Democracia..

1995 Estabelecida a Década de Educação em Direitos Humanos.

1996 Declaração de Salamanca sobre Princípios, Politicas e Pratica em Educação Especial.

1997 Plano de Ação para a Década da Nações Unidas.

1997 Diretrizes para a formulação de Planos Nacionais de Ação para a Educação em Direitos Humanos.

1998 Declaração Mundial sobre a Educação Superior no Século XXI: visão e ação.

1999 Direito à Educação em Direitos Humanos. Material produzido pelo OHCHR

2000 Adoção das Metas do Desenvolvimento do Milênio.

$2000 \quad$ Human Rights Training: A Manual on Human Rights Training Methodology (OHCHR Professional Training Series No. 6, 2000) 
2001 Conferencia Mundial contra o Racismo, a Discriminação Racial, a Xenofobia e Formas Correlatas de Intolerância realizada em Durban, África do Sul.

2001 Declaração Mundial da Diversidade Cultural

2001 Declaração do México sobre Educação em Direitos Humanos

2001 Década Internacional para uma Cultura de Paz e da Não-Violência para as Crianças do Mundo.

2001 Conferencia Regional sobre Educação em Direitos Humanos na América Latina, realizada em

2001 Seminário Latino-americano de Educação para a Paz e os Direitos Humanos, realizado na Venezuela.

2001 Plano Latino-Americano para a Promoção da Educação em Direitos Humanos.

2001 Conferencia Internacional da Educação em Genebra 2001.

2003 Brasil adota Plano Nacional de Direitos Humanos.

2004 Plano de Ação para a primeira fase (2005-2010) do Programa Mundial para a Educação em Direitos Humanos

2005 Programa Mundial para a educação em direitos humanos

2005 Lançado o Programa Mundial de Educação para Todos.

2006 Resolução 2006/19 da Subcomissão, intitulada "Programa Mundial para a Educação em Direitos Humanos."

2006 Programa Mundial para a Educação em Direitos Humanos - Plano de Ação UNESCO.

2006 Criação do Conselho de Direitos Humanos em substituição a Comissão de Direitos Humanos.

2006 Convenção sobre os Direitos das Pessoas com Deficiência.

2007 Informe da Alta Comissária da ONU para os direitos humanos correspondente a 2007 - (A/HRC/4/85). Programa Mundial para a Educação em Direitos Humanos:

2007 I Congresso Interamericano de Educação em Direitos Humanos.

2007 Resolução 6/10 do Conselho de Direitos Humanos, intitulada "Declaração das Nações Unidas sobre a educação e formação em direitos humanos" 
2007 Resolução 6/24 do Conselho de Direitos Humanos, intitulada: "Programa Mundial para a educação em direitos humanos."

2007 Resolução 6/9 do Conselho de Direitos Humanos, intitulada "Desenvolvimento de atividades de informação pública na esfera dos direitos humanos, em particular a Campanha Mundial de Informação Pública sobre os Direitos Humanos."

2008 Resolução 62/271 da Assembleia Geral, intitulada: "Ano Internacional de Aprendizagem sobre os Direitos Humanos."

2008 Informe da Alta Comissária da ONU para os direitos humanos correspondente a 2008 - (A/HRC/9/4)Informe da Alta Comissária da ONU para os direitos humanos correspondente a 2008 - (A/HRC/9/4). Programa Mundial para a Educação em Direitos Humanos:

2009 Plano de Ação da segunda fase (2010-2014) do Programa Mundial para a Educação em Direitos Humanos (A/HRC/15/28), as adopted by HRC resolution $15 / 11$

2009 "Final evaluation of the implementation of the first phase" - Programa Mundial para a Educação em Direitos Humanos Relatório da Comitê interagências do Direito à educação no sistema escolar.

2010 Recomendação 4/2: Anteprojeto de Declaração sobre a Educação em Formação em Direitos Humanos. 29.01.2010

2011 Apresentação do projeto sugerido pela Plataforma de Educação em Direitos Humanos.

2011 Aprovação do Projeto de Declaração das Nações Unidas sobre Educação e Formação em Direitos Humanos atraves da resolução $16 / 116^{\circ}$ período de sessões. Em 23.03.2011;

2011 Resolução 66/137: Adoção da Declaração das Nações Unidas sobre Educação e Formação em Direitos Humanos pela Assembleia Geral , em 19.12.2011; 


\title{
ANEXO II - Declaración de las Naciones Unidas sobre Educación e Formación en materia de Derechos Humanos.
}

Naciones Unidas

$\mathrm{A} / \mathrm{c}, 3 / 66 / 2.65$

Asamblea General

Distr. limitada

2 de noviembre de 2011

Espanol

Original: inglés

Sexagésimo sexto periodo de sesiones

Tercera Comisión

Tema 64 del programa

Informe del Consejo de Derechos Humanos

\begin{abstract}
Albania, Alemania, Argentina, Australia, Austria, Brasil, Bulgaria,
Chile, Chipre, Colombia, Costa Rica, Croacia, Eslovaquia, Eslovenia,

Filipinas, Grecia, Guatemala, Honduras, Hungria, Indonesia, Israel,

Italia, Lituania, Luxemburgo, Marruecos, México, Montenegro,

Noruega, Panamá, Perú, Polonia, Portugal, Rumania, Senegal, Serbia,

Suiza, Uerania y Venezuela (República Bolivariana de): proyecto de

resolución
\end{abstract}

Declaración de las Naciones Unidas sobre educación

y formación en materia de derechos humanos

La Asamblea General,

Acogiendo con beneplácifo la aprobación por el Consejo de Derechos Humanos de la Declaración de las Naciones Unidas sobre educación y formación en materia de derechos humanos mediante su resolución 16/1 , de 23 de marzo de 2011,

1. Aprueba la Declaración de las Naciones Unidas sobre educación y formación en materia de derechos humanos que figura en el anexo de la presente resolución;

2. Invita a los gobiernos, a los organismos y organizaciones del sistema de las Naciones Unidas y las organizaciones intergubernamentales y no gubernamentales a que intensifiquen sus esfuerzos por difundir la Declaración y promover el respeto hacia ella y su comprensión a nivel universal, y pide al Secretario General que incluya el texto de la Declaración en la próxima edición de Derechos humanos: recopilación de instrumentos internacionales.

Véase Documentos Oficiales de la Asamblea General, sexagésimo sexto periodo de sesiones. Suplemento nä̀. 53 (A/66/53), cap. I. 
Anexo

Declaración de las Naciones Unidas sobre educación y formación

en materia de derechos humanos

La Asamblea General,

Reafirmando los propósitos y principios de la Carta de las Naciones Unidas relativos a la tarea de promover y fomentar el respeto de todos los derechos humanos y las libertades fundamentales de todos sin distinción por motivos de raza, sexo, idioma o religión,

Reafirmando también que tanto los individuos como las instituciones deben promover, mediante la ensefianza y la educación, el respeto de los derechos humanos y las libertades fundamentales.

Reafirmando además que toda persona tiene derecho a la educación, y que la educación debe orientarse hacia el pleno desarrollo de la personalidad humana y del sentido de su dignidad, capacitar a todas las personas para participar efectivamente en una sociedad libre, favorecer la comprensión, la tolerancia y la amistad entre todas las naciones y todos los grupos raciales, étnicos o religiosos y promover el desarrollo de las actividades de las Naciones Unidas para el mantenimiento de la paz, la seguridad y el fomento del desarrollo y de los derechos humanos,

Reafirmando el deber de los Estados, explicitado en la Declaración Universal de Derechos Humanos, en el Pacto Internacional de Derechos Económicos, Sociales y Culturales y en otros instrumentos de derechos humanos, de encauzar la educación de manera que se fortalezca el respeto de los derechos humanos y las libertades fundamentales,

Reconociendo la importancia fundamental de la educación y la formación en materia de derechos humanos para la promoción, protección y realización efectiva de todos los derechos humanos,

Reafirmando el llamamiento de la Conferencia Mundial de Derechos Humanos, celebrada en Viena en 1993, a todos los Estados e instituciones para que incluyeran los derechos humanos, el derecho humanitario, la democracia y el imperio de la ley como temas de los planes de estudios de todas las instituciones de enseñanza, y su declaración de que la educación en materia de derechos humanos debe abarcar la paz, la democracia, el desarrollo y la justicia social, tal como se dispone en los instrumentos internacionales y regionales de derechos humanos, a fin de lograr una concepción común y una toma de conciencia colectiva que permitan afianzar el compromiso universal en favor de los derechos humanos,

Recordando el Documento Final de la Cumbre Mundial 2005, en que los Jefes de Estado y de Gobierno apoyaron la promoción de la educación y la formación en materia de derechos humanos a todos los niveles, entre otras cosas mediante la ejecución del Programa Mundial para la educación en derechos humanos, e instaron a todos los Estados a preparar iniciativas en ese sentido,

Resolución 217 A (III)

Vease la resolución $2200 \mathrm{~A}(\mathrm{XX1})$, anexo.

A/CONF, 157/24 (Part D), cap, III, sec, II, pirrs. 79 y 80.

Resolución $60 / 1$ de la Asamblea General. 
Movida por el deseo de dar a la comunidad internacional una señal clara para intensificar todos los esfuerzos relativos a la educación y la formación en materia de derechos humanos mediante el compromiso colectivo de todas las partes interesadas,

Declara lo siguiente:

\section{Artículo 1}

1. Toda persona tiene derecho a obtener, buscar y recibir información sobre todos los derechos humanos y las libertades fundamentales y debe tener acceso a la educación y la formación en materia de derechos humanos.

2. La educación y la formación en materia de derechos humanos son esenciales para la promoción del respeto universal y efectivo de todos los derechos humanos y las libertades fundamentales de todas las personas, de conformidad con los principios de universalidad, indivisibilidad e interdependencia de los derechos humanos.

3. El disfrute efectivo de todos los derechos humanos, en particular el derecho a la educación y al acceso a la información, facilita el acceso a la educación y la formación en materia de derechos humanos.

\section{Artículo 2}

1. La educación y la formación en materia de derechos humanos están integradas por el conjunto de actividades educativas y de formación, información, sensibilización y aprendizaje que tienen por objeto promover el respeto universal y efectivo de todos los derechos humanos y las libertades fundamentales, contribuyendo así, entre otras cosas, a la prevención de los abusos y violaciones de los derechos humanos al proporcionar a las personas conocimientos, capacidades y comprensión y desarrollar sus actitudes y comportamientos para que puedan contribuir a la creación y promoción de una cultura universal de derechos humanos.

2. La educación y la formación en materia de derechos humanos engloban:

a) La educación sobre los derechos humanos, que incluye facilitar el conocimiento y la comprensión de las normas y principios de derechos humanos, los valores que los sostienen y los mecanismos que los protegen;

b) La educación por medio de los derechos humanos, que incluye aprender y enseñar respetando los derechos de los educadores y los educandos:

c) La educación para los derechos humanos, que incluye facultar a las personas para que disfruten de sus derechos y los ejerzan, y respeten y defiendan los de los demás.

\section{Artículo 3}

1. La educación y la formación en materia de derechos humanos son un proceso que se prolonga toda la vida y afecta a todas las edades.

2. La educación y la formación en materia de derechos humanos conciernen a todos los sectores de la sociedad, a todos los niveles de la enseñanza, incluidas la educación preescolar, primaria, secundaria y superior, teniendo en cuenta la libertad académica donde corresponda, y a todas las formas de educación, formación y 
Movida por el deseo de dar a la comunidad internacional una señal clara para intensificar todos los esfuerzos relativos a la educación y la formación en materia de derechos humanos mediante el compromiso colectivo de todas las partes interesadas,

Declara lo siguiente:

\section{Artículo 1}

1. Toda persona tiene derecho a obtener, buscar y recibir información sobre todos los derechos humanos y las libertades fundamentales y debe tener acceso a la educación y la formación en materia de derechos humanos.

2. La educación y la formación en materia de derechos humanos son esenciales para la promoción del respeto universal y efectivo de todos los derechos humanos y las libertades fundamentales de todas las personas, de conformidad con los principios de universalidad, indivisibilidad e interdependencia de los derechos humanos.

3. El disfrute efectivo de todos los derechos humanos, en particular el derecho a la educación y al acceso a la información, facilita el acceso a la educación y la formación en materia de derechos humanos.

\section{Articulo 2}

1. La educación y la formación en materia de derechos humanos están integradas por el conjunto de actividades educativas y de formación, información, sensibilización y aprendizaje que tienen por objeto promover el respeto universal y efectivo de todos los derechos humanos y las libertades fundamentales, contribuyendo así, entre otras cosas, a la prevención de los abusos y violaciones de los derechos humanos al proporcionar a las personas conocimientos, capacidades y comprensión y desarrollar sus actitudes y comportamientos para que puedan contribuir a la creación y promoción de una cultura universal de derechos humanos.

2. La educación y la formación en materia de derechos humanos engloban:

a) La educación sobre los derechos humanos, que incluye facilitar el conocimiento y la comprensión de las normas y principios de derechos humanos, los valores que los sostienen y los mecanismos que los protegen;

b) La educación por medio de los derechos humanos, que incluye aprender y enseñar respetando los derechos de los educadores y los educandos:

c) La educación para los derechos humanos, que incluye facultar a las personas para que disfruten de sus derechos y los ejerzan, y respeten y defiendan los de los demás.

\section{Artículo 3}

1. La educación y la formación en materia de derechos humanos son un proceso que se prolonga toda la vida y afecta a todas las edades.

2. La educación y la formación en materia de derechos humanos conciernen a todos los sectores de la sociedad, a todos los niveles de la enseñanza, incluidas la educación preescolar, primaria, secundaria y superior, teniendo en cuenta la libertad académica donde corresponda, y a todas las formas de educación, formación y 
tradiciones de los diferentes paises, reflejada en la universalidad de los derechos humanos, e inspirarse en ella.

4. La educación y la formación en materia de derechos humanos deben tener en cuenta las diferentes circunstancias económicas, sociales y culturales, favoreciendo al mismo tiempo las iniciativas locales a fin de fomentar la apropiación del objetivo común que es la realización de todos los derechos humanos para todos.

\section{Articulo 6}

1. La educación y la formación en materia de derechos humanos deben aprovechar y utilizar las nuevas tecnologias de la información y las comunicaciones, así como los medios de comunicación, para promover todos los derechos humanos y las libertades fundamentales.

2. Deben alentarse las artes como medio de formación y sensibilización en la esfera de los derechos humanos.

\section{Articulo 7}

1. Los Estados y, según corresponda, las autoridades gubernamentales competentes, son los principales responsables de promover y garantizar la educación y la formación en materia de derechos humanos, concebidas e impartidas en un espiritu de participación, inclusión y responsabilidad.

2. Los Estados deben erear un entorno seguro y propicio para la participación de la sociedad civil, el sector privado y otros interesados pertinentes en la educación y la formación en materia de derechos humanos, en que se protejan integramente los derechos humanos y las libertades fundamentales de todos, incluidos los que participan en el proceso.

3. Los Estados deben adoptar medidas, individualmente y con la asistencia y la cooperación internacionales, para garantizar, hasta el máximo de los recursos de que dispongan, la aplicación progresiva de la educación y la formación en materia de derechos humanos a través de los medios adecuados, en particular la adopción de politicas y medidas legislativas y administrativas.

4. Los Estados y, según corresponda, las autoridades gubernamentales competentes deben garantizar la formación adecuada en derechos humanos y, si procede, en derecho internacional humanitario y derecho penal internacional, de los funcionarios y empleados públicos, los jueces, los agentes del orden y el personal militar, así como promover la formación adecuada en derechos humanos de maestros, instructores y otros educadores y personal privado que desempenten funciones a cuenta del Estado.

\section{Artículo 8}

I. Los Estados deben formular o promover la formulación, al nivel adecuado, de estrategias y políticas y, según corresponda, de programas y planes de acción, para impartir educación y formación en materia de derechos humanos, por ejemplo integrándolas en los planes de estudios de las escuelas y en los programas de formación. A ese respecto, deben tener en cuenta el Programa Mundial para la 
educación en derechos humanos y las necesidades y prioridades locales y nacionales especificas.

2. En la concepción, aplicación, evaluación y seguimiento de las estrategias, los planes de acción, las politicas y los programas deben participar todos los interesados pertinentes, entre otros el sector privado, la sociedad civil y las instituciones nacionales de derechos humanos, alentando, según corresponda, las iniciativas de múltiples interesados.

\section{Artículo 9}

Los Estados deben fomentar la creación, el desarrollo y el fortalecimiento de instituciones nacionales de derechos humanos eficaces e independientes, conforme a los Principios relativos al estatuto de las instituciones nacionales de promoción y protección de los derechos humanos (los Principios de París), reconociendo que esas instituciones pueden desempeñar un papel importante, incluida, si fuera necesario, una función de coordinación, en la promoción de la educación y la formación en materia de derechos humanos, entre otras cosas concienciando y movilizando a los agentes públicos y privados pertinentes.

\section{Artículo 10}

1. Diversos actores sociales, como las instituciones educativas, los medios de comunicación, las familias, las comunidades locales, las instituciones de la sociedad civil, en particular las organizaciones no gubernamentales, los defensores de los derechos humanos y el sector privado, pueden contribuir de manera importante a promover e impartir la educación y la formación en materia de derechos humanos.

2. Se alienta a las instituciones de la sociedad civil, al sector privado y a otros interesados pertinentes a velar por que su personal reciba educación y formación adecuadas en materia de derechos humanos.

\section{Articulo 11}

Las Naciones Unidas y las organizaciones internacionales y regionales deben impartir educación y formación en materia de derechos humanos a su personal civil, asi como al personal militar y policial que preste servicios con arreglo a sus mandatos.

\section{Articulo 12}

1. La cooperación internacional a todos los niveles debe respaldar y reforzar las actividades nacionales, incluidas, cuando corresponda, las de nive local, dirigidas a impartir educación y formación en materia de derechos humanos.

2. Las actividades complementarias y coordinadas a nivel internacional, regional, nacional y local pueden contribuir a que la educación y la formación en materia de derechos humanos se impartan con mayor eficacia.

3. Debe alentarse la financiación voluntaria de proyectos e iniciativas en la esfera de la educación y la formación en materia de derechos humanos.

Resolución 48/134, anexo. 


\section{Artículo 13}

1. Los mecanismos internacionales y regionales de derechos humanos deben, conforme a sus respectivos mandatos, tener en cuenta en su trabajo la educación y la formación en materia de derechos humanos.

2. Se alienta a los Estados a que incluyan, cuando proceda, información sobre las medidas adoptadas en el ámbito de la educación y la formación en materia de derechos humanos en los informes que presenten a los mecanismos pertinentes de derechos humanos.

\section{Artículo 14}

Los Estados deben adoptar medidas adecuadas para velar por la aplicación eficaz y el seguimiento de la presente Declaración y facilitar los recursos necesarios para ello. 